\title{
THE COLOURED WORKER IN
}

\section{BRITISH INDUSTRY}

\section{with special reference to the Midlands and North of England}

\section{by}

\author{
PETER L. WRIGHT
}

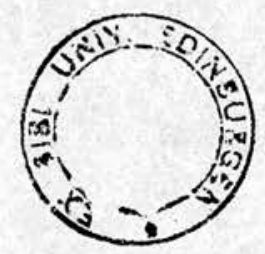

Thesis presented for the Degree of Doctor of Philosophy of the University of Edinburgh in the Faculty of Social Sclences, December 1965.- 


\section{THE UNIVERSITY of EDINBURGH}

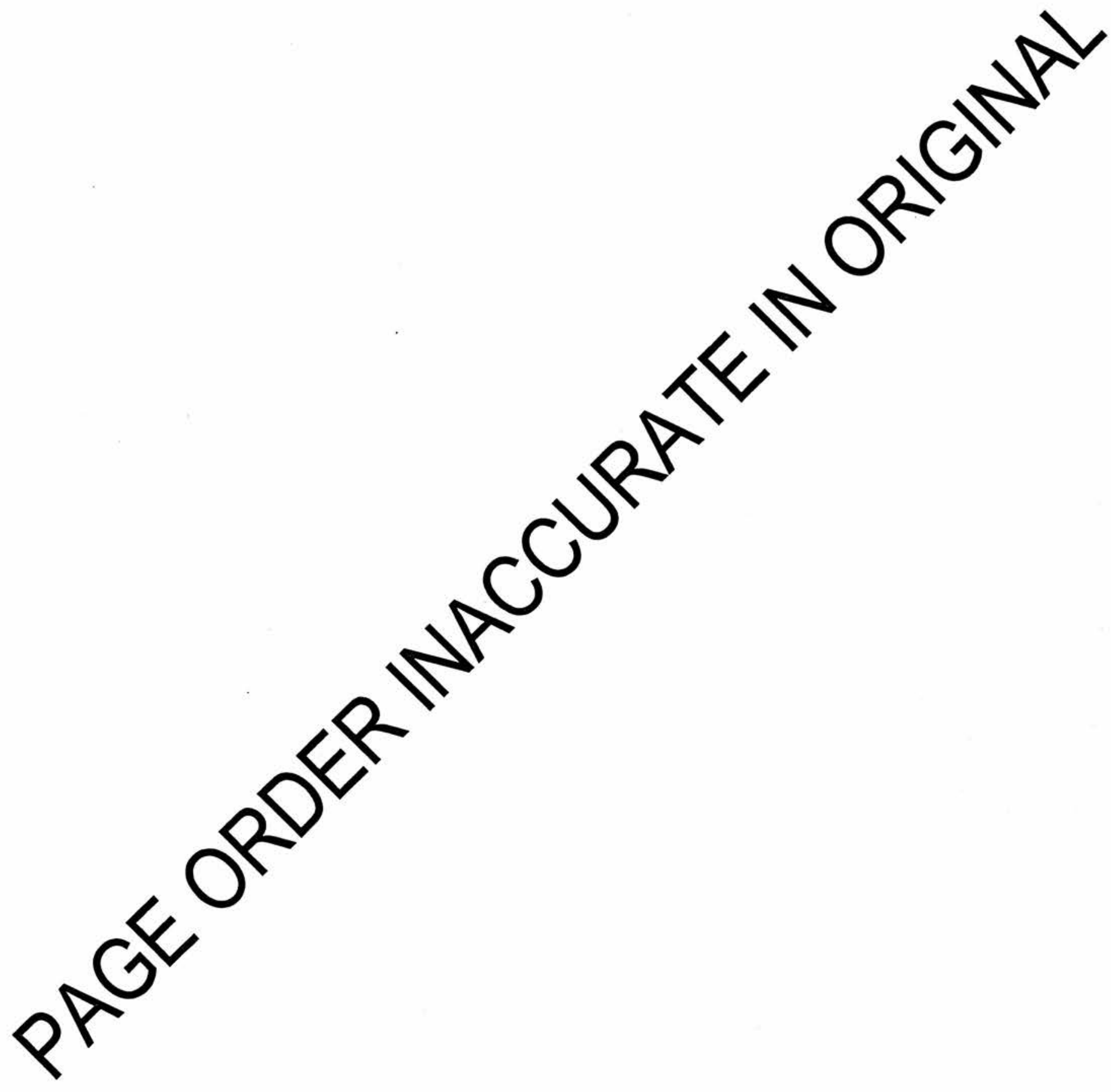




\section{CONTENTS}

LIST OF TABLES

Page

LIST OF FIGURES

INTRODUCTION

111

iv

1. THE THEORETICAL BACKGROUND: RACE RELATIONS AND IMMIGRATION

2. THE BRITISH RACIAL SCENE

3. THE ECONOMIC BACKGROUND TO MIGRATION

4. INTEGRATION INTO THE WORK ORGANISATION:

EMPLOYMENT AND OCCUPATIONAL LEVELS

5. MANAGERIAL BELIEFS AND ATTITUDES CONCERNING THE EMPLOYMENT OF COLOURED WORKERS: SKILL AND TRAINING

6. MANAGERIAL BELIEFS AND ATTITUDES CONCERNING THE EMPLOYMENT OF COLOURED WORKERS: DILIGENCE, FLEXIBILITY AND SUPERVISION

7. EQUALITY OF TREATMENT, JOB SATISFACTION AND LABOUR TURNOVER

8. INTERGROUP RELATIONS AT WORK

9. SUMMARY AND CONCLUSIONS

APPENDIX I FIRMS VISITED DURING THE INTERVIEW SURVEYS

APPENDIX II INTERVIEW SCHEDULE: PILOT SURVEY

APPENDIX III INTERVIEW SCHEDULE: DIRECTIVE INTERVIEW SURVEY

454

APPENDIX IV QUESTIONNAIRE SURVEY SCHEDULE 


\section{LIST OF TABLES}

Page

1. Annual Imm1gration from West Indies

2. The British Coloured Population since the 1961 Census

3. Previous Occupations of Jamaican Migrants October, 1954

4. Occupational Class of Male Departures from Jamaica to the U.X. to Seek Work, 1953-1955

5. Occupational Distribution of Emigrants from Barbados, October, 1955

140

6. Claimed Occupations of Dominican Emigrants to the U.K.

7. Occupational Distribution of West Indian Migrants in the 'London Sample'

8. Percentage Distribution of Previous Occupations of Coloured Immigrants in Britain, Summer 1961

9. Percentage Distribution of Previous Occupations of West Indian, Indian and Pakistani Manual Workers

10. Reasons given for Initial Employment of Coloured Workers (Questionnaire Survey)

11. White and Coloured Unemployment in Five Yorkshire Towns; May 1962

12. Coloured Unemployment in Great Britain 19601963

13. Ratios of West Indian to Asian Workers (Interview and Questionnaire Surveys)

14. Occupational Level of British, Coloured and White Immigrant Workers

15. Managers' Assessments of the Skill Level of Coloured Workers (Questionnaire Survey)

16. Managerial Assessments of the Diligence of Coloured Workers (Questionnaire Survey)

17. Managerial Assessments of the Flexibility of Coloured Workers (Questionnaire Survey) 
18. Managerial Assessment of the Supervisory

Requirements of Coloured Workers

(Questionnaire Survey)

19. Managerial Assessment of the Amenability to Discipline of Coloured Workers

(Questionnaire Survey)

20. Work Acceptance in Relation to Job Status 354

21. National Preference of White Workers 356

22. Occurrence of Complaints concerning Misuse of Toilets

23. Work Relations Between Different Coloured Nationalities

403

24. Social Relations Between Different Coloured Nationalities

403

\section{LIST OF FIGURES}

1. White and Coloured Unemployment on Merseyside 1930-1950

Page

170

2. Proportion of Coloured Workers in the Total Labour Force (Interview and Questionnaire Surveys)

3. Proportion of West Indian and Asian Workers in the Total Labour Force (Interview and Questionnaire Surveys)

4. Occupational Distribution of British, Coloured and White Immigrant Workers (Questionnaire Survey)

5. Occupational Distribution of Coloured Workers (Questionnaire Survey)

6. Estimated Skill of West Indian Immigrants Compared with Occupational Level 


\section{INTRODUCTION}

\section{Purpose of the Research and Field-Work Methods}

Th1s thesis is the outcome of a study begun in 1961 with the aim of providing much needed information concerning the employment aspect of coloured immigration to Britain. Previous research into race relations in Britain had tended to concentrate more upon the community than the industrial environment, and whilst some information concerning the employment situation was avallable, an overall picture was lacking.

The rescarch project began with a series of interviews with managers of firms employing coloured immigrants. This was intended at first merely as a means of obtaining background data for a more objective study. In all, fourteen firms were visited; in two cases contact was made via the Institute of Race Relations and in the other twelve by means of introductions from Employment Exchange managers. Non-directive interviewing was used in the main. As the intention was to obtain background data, it was felt that it was better to allow the managers to discuss what they considered important, rather than to ask specific questions which may not have been relevant. Often it was possible to elicit most of the information required simply by asking when the firm had begun to employ 
coloured workers. The manager would answer this question and then go on to other topics as they occurred to him. Only when the respondent failed to touch upon some general topic which seemed important, such as supervision or labour turnover, were further questions asked. In keeping with the nondirective technique, these questions were only of a general nature, e.g., "How do you find coloured workers with respect to supervision (or labour turnover, etc.)?" Fairly detailed notes were taken during these interviews, but in no case did this appear to have a detrimental effect on the rapport.

As this stage of the enquiry progressed, it became increasingly apparent that the information gained was much too significant to be used merely as background data, and more time was spent on it than had originally been intended. At the same time, it was equally apparent that a report from management alone was not sufficient to provide a complete picture of race relations in a particular firm.

There seemed to be two obvious ways of rounding out this picture. One was to carry out observational studies of white and coloured workers in the context of both the formal and the informal organisation. The other was to carry out interviews with white workers, coloured workers and supervisors, similar to those which had already been carried out with management. In this way it would be possible to obtain opinions from four different viewpoints and thus, it was hoped, to be in a position to build up a composite picture. 
observational study had already been carried out in one of the firms visited (Bradfield Foundry) ${ }^{1}$. Much useful data was obtained, but the main drawback to this method was the fact that 1t was somewhat time consuming and would permit only a relatively small number of firms to be studied. It was therefore decided to use the interview method and to return to observational techniques in a further two or three firms when this stage had been completed. Unfortunately, by the time the second set of interviews had been carried out and the data analysed, time did not permit further field work and it proved impossible to carry out further observational studies.

Pilot interview schedules ${ }^{2}$ for the interviews with workers and supervisors were tested in two of the firms already visited in the course of the management interviews (Edge Tools Ltd. and Omega Metals Ltd.). Based on this experience the interview schedules were modified and a further schedule evolved for management representatives. ${ }^{3}$ Letters were then sent to some fifty firms in two industrial cities in the North of England, enquiring whether it would be possible to interview a member of management on the question of the employment of coloured workers. Affirmative answers were obtained in seventeen cases.

All seventeen firms were visited and at least one member of management interviewed. At the end of the interview, the writer

1. The results of this study are described in Chapter Eight. 2. See Appendix II.

3. See Appendix III. 
asked whether he could carry out further interviews with white workers, coloured workers and supervisors. Permission to do so was granted in thirteen cases. For a number of reasons, however, it proved impossible to interview a representative sample of white and coloured workers in any of these firms. Managers naturally wished to disrupt production as little as possible and the number of interviews granted was relatively small, varying from one in one firm to nine in another. In some cases managers stated that it was impossible to take the workers away from their jobs and as a result the interviews had to be carried out at the respondent's place of work which limited their scope considerably. Furthermore, the interviews with Aslan workers were limited by the writer's inaility to speak any of their languages and the respondents' lack of facility with English. Respondents had, therefore, to be selected for their ability to speak at least some English, a procedure which introduces a further bias. These difficulties, of necessity, limit the value of the data obtained from the interviews with white and coloured workers. Nevertheless, it is difficult to see how they could have been avoided, and the writer has found the material a useful check on, and often addition to, the data already obtained from management interviews.

Finally, in order to obtain some idea of how representative were the firms visited in the course of the management interviews, a postal questionnaire ${ }^{1}$ was sent to one hundred and 
fifty firms in the Midlands where coloured workers were known or thought likely to be employed. Fifty completed ${ }^{1}$ questionnaires were returned, and in a further thirty-five cases some data concerning either the number of coloured workers employed or the firm's attitude towards the employment of coloured labour were obtained.

For purposes of convenience, the three stages of the present study will be referred to as the non-directive survey, the directive interview survey and the questionnaire survey respectively. In the text of the thesis, the firms visited in the course of the non-directive and the directive interview surveys are referred to by pseudonyms; it should be stressed that these are not the real names of the firms concerned. In footnotes, this procedure was often too unwieldy, especially when a long list of firms was being given, and here they are mainly identified by numbers. These numbers can be related to the relevant pseudonym in Appendix I where a brief description of the firm concerned is also given.

The present study was carried out between 1961 and 1964 whilst the writer was a research worker for the Institute of

1. 1.e., "completed" in the sense that the respondent had answered most of the questions. Often, however, the answers related only to the particular coloured group or groups employed by the firm. Answers to the questionnaire survey are therefore presented as a percentage of the total number of respondents supplying data concerning the group in question. 
Race Relations. The research was supervised by Dr. Michael Banton of the Department of Social Anthropology and Mr. R. M. McKenzie of the Department of Industry and Commerce at Edinburgh University. The writer wishes to thank the Joseph Rowntree Memorial Trust whose grant made the research possible and Dr. Banton and Mr. McKenzie for their guidance and criticism, and the staff of the Institute of Race Relations for all their assistance. 
CHAPTER ONE

\section{THE THEORETICAL BACKGROUND: RACE}

\section{RELATIONS AND IMMIGRATION}

\section{Preliminary Summary}

In this Chapter, we shall advance two main arguments. Firstly, it w1ll be suggested that such concepts as assimilation and absorption cannot adequately describe or explain the immigration process. These concepts have blological connotations and imply a swallowing up and transformation of 1mmigrants until they become indistinguishably merged into the host society. Research studies have shown that, in practice, the process of immigrant-host adjustment often does not follow this pattern, and the concept of integration is advanced as a more viable alternative. Secondly, it will be argued that the central position allotted to the concept of prejudice in the study of race relations is unfustified in that it leads to an over-emphasis upon personality factors at the expense of sociological considerations. We will suggest that the concepts of social distance and social conflict provide a more adequate theoretical framework within which to examine intergroup relations. 


\section{Introduction}

The section of the community with whom we are here concerned may be distinguished from the population as a whole in two main respects: firstly, they are coloured; and secondly, they are immigrants. Obvious though this point may be, it is important that it should be kept firmly in mind, for it is crucial to the understanding of the pattern of race relations in Britain. All too often, only one factor, namely colour, is taken into account when attempting to explain the situation. In its most facile form, this approach can be found in the argument that all we have to do to solve the "race problem" is to cure the majority group of colour prejudice and thus remove the colour bar which prevents coloured people from enjoying full social equality. In fact, however, the problems encountered by coloured immigrants arise partly because they are coloured, partly because they are 1mm1grants and partly because they are both. Thus to concentrate solely on the colour prejudice aspect is to foredoom to fallure any attempt to solve the problem by grossly over-simplifying 1 t.

The theoretical background to the present research, falls therefore into two maln categories; firstly, immigration studies, and secondly, race relations. Although these two spheres of enquiry often overlap, each has tended to develop Its own concepts, theories and terminology. As both have equal relevance to our subject matter, we will present a brief outline of the major developments in each field and then attempt to extract those elements which have greatest application to 
the main topic of the present study, the coloured immigrant in industry.

\section{Studies of Immigration}

The main concern in studies of 1mmigration has been with the process of adjustment which takes place between immigrants and the members of the society into which they have moved. Over the years, this process has been given a variety of names and there have been different theories purporting to explain how it occurs. Faced with a plethora of concepts such as assimilation, adaptation, acclimatisation, accommodation, absorption, acculturation, transculturation, integration and so on, one reaction has been to ignore terminological differences and assume that they all describe the same underlying phenomenon. Th1s would appear to be the view taken at the Unesco conference on cultural integration held in Havana in 1956. According to Borrie (1959), the conference "attempted to be severely practical and to avoid undue argument about the precise meanings which different delegates attributed to such words as 'integration', 'assimilation' or 'absorption'. The conference tended to accept the pragmatic view that whatever term may be used, all are concerned with a process of economic, social and cultural adjustment, and that the deliberations of the conference should be concerned with the major problems in the process."

In view of the fact that a previous conference on the cultural assimilation of immigrants (see Glass, 1950) had ended without agreement being reached on a derinition of 
assimilation, it was undoubtedly expedient to avoid the timeconsuming ramifications arising from this problem during an elght day conference. Such considerations do not apply here, however, and it would be unwise to avoid the question.

One of the major difficulties involved is not so much the number of terms, but the fact that many of them not only denote the process of Immigrant-host adjustment, but also carry implicit assumptions as to how it is achieved. In particular, this applies to the concept of assimilation which, in Borrie's words, "has frequently retalned a substantial trace of 1 ts physiological analogy." That is, it suggests that an immigrant, once assimilated, becomes indistinguishably merged into the host society in much the same way as food stuff becomes an integral part of the organism which digests it. Recent research has suggested that this analogy is by no means valid when applied to all aspects of 1mmigrant-host adjustment. Consequently, it may be highly misleading to use this term and others like it without first stipulating precisely what they are and are not intended to convey. In as much as later concepts were largely developed as a result of a reaction against earlier concepts, this necessitates an examination of the earlier orientations towards the process of Immigrant-host adjustment.

(a) Barly Approaches to the Theory of Immigration

The early history of immigration theory is virtually a history of American attitudes towards the assimilation of European Immigrants into the United States. Prior to the First World War, the philosophy which prevailed towards the various 
ethnic elements in the American population was symbolised in the phrase "the melting pot". Although certain groups such as Negroes, Orientals and Indians were thought to be unassimilable, 1t was assumed that Buropean 1mmigrants would fuse with members of the host society and thus produce a homogeneous culture. This process of fusion, it was belleved, would occur as a natural course of events without outside interference. The American environment would of itself exert those pressures on the Immigrant which would make him an integral part of the American community. As Berry (1951) succinctly puts 1t: "The melting pot theory represented the doctrine of lalssez-falre applied to the realm of race and culture contact."

The advent of the First World War rudely shattered this complacency. It soon became apparent that assimilation was not the easy, rapid, natural and inevitable process it had seemed. "When the nation began to take stock of 1tself, the startling fact emerged that there were millions in the country who could nelther read, speak, nor write English; less than half the forelgn-born white males of voting age were citizens; there were thousands of organisations flourishing among the foreign elements, and hundreds of newspapers and periodicals published in foreign languages; immigrants were concentrated in 'colonies' in the cities, and foreign governments were in the habit of encouraging their nationals to retain their old allegiance, not without some success." 1

1. Berry (op. cit.) 
Assimilation, therefore, was no longer to be left to chance. The necessity for national solidarity in times of war gave rise to a formal movement of 'Americanisation' designed to supplement the play of natural forces. This movement consisted of an attempt to suppress the Immigrant's native culture and to inculcate him with the American way of life. Efforts were made to teach English to the immigrants and to stimulate their naturalisation. In many States, the teaching of common school subjects in any language other than Finglish was prohibited by law, and attempts were made to suppress 1mmigrant newspapers and organisations.

Unfortunately, the Americanisation movement was based upon an equally fallacious conception of the assimilation process as the previous melting pot theory. Its defects are summarised by Berry as follows. "It made the mistake of ignoring the values in the cultures of the immigrants and assuming that these must, and could, be discarded as though they were old garments. It 1nvolved a tacit assumption that American culture was a finished product, in an Anglo-Saxon pattern, that 1 t was superior to all others, and that aliens should promptly acquire 1t. Implicit in the movement was a spirit of coercion, condescension and suppression, which aroused the resentment of those at whom it was directed and in the end served to defeat 1 ts purpose." As a result the term fell into disrepute.

However, the revelation that there were vast numbers of unassimilated immigrants and the resultant fear that this would 
seriously impair national solidarity had by this time had a considerable effect on the academic as well as the popular theories of assimilation. 1 This effect can be seen in the analysis of the concept of assimilation made by Fairchild in 1924. After examining several dictionary definitions of the term, he comes to the conclusion that the essence of assimilation is "likeness or conformity." This in turn, he suggests, Implies a type to which such likeness approaches which, in his view, is manifestly the "American type." Whilst Fairchild admits that it might be difficult to say just what this type 1s, and that some writers even doubt its existence, he maintains that "the very idea of assimilation presupposes a type (and) this type in the United States is the 'native American'."

Moreover, Fairchild maintains that it would be incorrect to speak of assimilation when there is nothing more than resemblance to this "American type." He states that "it seems.......clear that complete assimilation involves identity." In this respect, he claims, the assimilation of immigrants by a host society is analogous to the assimilation of food into the body. "When nutriment is taken into a living organism, it passes through certain processes by which it becomes an integral part of that organism. It is then said to be assimilated. Every suggestion of separate origin disappears..........Any portion of food which created a disturbance with reference to 1. In fact, it would appear that this effect lasted even longer In the academic sphere. In 1930, we find Park still equating assimilation with Americanisation in the same issue of the Incrclopaedia of the Soclal Sciences as Lewis states that the term had fallen into a disrepute "from which it has never recovered." 
the body would not be sald to be assimilated. Transferred to the fleld of population, it means that true and complete assimilation of the foreign elements in the United States involves such a complete transformation and uniflcation of the new constituents that all sense of difference between old and new disappears."

There has been considerable criticism of Fairchild's approach to assimilation in recent years. Before discussing the weaknesses of this theory, however, we will first examine the more sophisticated analysis of the concept of assimilation carried out ky Park in 1930. In an article in the Encyclopaedia of the Social Sclences, Park defines assimilation as "the name given to the process or processes by which people of diverse racial origins and different cultural heritages, occupying a common territory, achieve cultural solidarity sufficient at least to maintair a national existence." In the United States, he suggests, "an immigrant is normally considered assimilated as soon as he has acquired the language and the social ritual of the native community and can participate, without encountering prefudice, in the common life, economic and political."

Park recognises two barriers to assimilation: national or racial consciousness on the part of the immigrant and nonacceptance of the immigrant on the part of the host community. He further suggests that these two barriers to assimilation may interact, in that self consciousness on the part of the immigrant "arises inevitably as soon as the alien, seeking residence in 
a foreign country, finds himself for any reason set apart and segregated geographically, so that intercourse is measurably confined to members of his own raclal group."

The case of the American Negro, who has not been assimilated after three hundred years in the United States whilst second generation Poles, Lithuanians or Norwegians are proverblally indistinguishable from the older American stock, leads Park to suggest that "assimilation may in some senses and to a certain degree be described as a function of visibility." That is, as soon as the immigrant no longer exhibits the marks which 1dentify him as a member of an alien group, he acquires by that fact the actual if not the legal status of a native. But the Negro and immigrants who "bear a distinctive racial mark" can always be distinguished from other members of the society and are therefore faced with considerable difficulty in becoming assimilated and perhaps, in the short run at least, with insurmountable barriers. Park concludes that: "The ease and rapidity with which allens have been able to take over American customs and manners have enabled the United States to digest any sort of normal human difference, with the exception of the purely external ones like that of the colour of the skin." (italics mine)

Thus far, there is very little in Park's ofefinition of, and approach to, assimilation to which the present-day immigration or race relations theorist could take exception. His definition is carefully worded, well qualified, and largely avoids the excesses of either the Americanisation movement or earlier 
theorists such as Fairchild. However, both in the article we have so far examined and elsewhere, Pakk makes additions to his original concept which modify it considerably and in some cases contradict 1t. On analysis of Park's writings, it is apparent that, at one time or another, he held that: 1) assimilation is inevitable; 2) that complete assimilation involves identity; and 3) that assimilation is a one-way process. It is these aspects of Park's theory, in which the influence of the Americanisation movement is readily apparent, which have led some writers to revise the earlier concept of assimilation and others to abandon the concept altogether.

1. The Inevitability of Assimilation

In 1926, in Survey Graphic, Park put forward the theory that there is a "race relations cycle", that is, a cycle of events which tends everywhere to repeat itself whenever different races meet. According to this theory, initial contact is followed by economic competition, which in turn gives rise to political and cultural conflict. Out of this "confusion and ferment", a modus viviendi is reached which eventually leads, through the development of personal and human relations from those which were originally merely formal or utilitarian, to assimilation. In Park's own words, "the race relations cycle......takes the form, to state It abstractly, of contacts, competition, accommodation and eventual assimilation." This cycle of events was described as "progressive and 1rreversible." "Customs regulations, immigration restrictions and racial barriers 
may slacken the tempo of the movement, may halt it altogether for a time; but cannot change its direction; cannot at any rate reverse it."

Park himself recognised one of the major inadequacies of this theory in his later article in the Encyclopaedia of the Social Sciences, namely that the existence of unassimilated minority groups, such as the Negro in America and the Jews in Furope, makes untenable the view that assimilation is an inevitable result of race or culture contact. of course, it would be possible to argue that this unassimilated state is merely a temporary phase in a long term cycle whlch must eventually lead to assimilation. But when such a "temporary phase" can last three hundred years, as in the case of the American Negro, or two thousand years, as in the case of the Jews in Europe, such a theory can be of little use to the social scientist, nor much comfort to a depressed minority.

Park's original theory of assimilation has also been criticised on these grounãs by other writers. Berry, for example, admits that there are some cases where a certain degree of assimilation has taken place in spite of a desire on the part of the groups concerned to remain separate, which gives some support to those sociologists who insist that, given sufficient time, complete assimilation will take place. He points out, however, that there are also instances "where ethnic 
groups have been in contact for long periods of time, where assimilation has been at a bare minimum, and where one would have to posit a very long time indeed for the fusion of cultures." Three such instances are, he suggests: 1) the Rumanians, Magyars and Germans on the Transylvanian Plateau in Central Europe; 2) various Indian groups in Guatemala; and 3) the Todas, Bagadas, Kotas and Kurumbas in the Nilgiri Hills in Southern India. Similarly, Lieberson (1961) suggests that the sharp contrasts between the relatively harmonious race relations in Brazil and Hawail and the current racial turmoil in South Africa and Indonesia serve to illustrate the difficulty in stating - to say nothing of interpreting an inevitable 'natural history' of race relations, as has been attempted by Park and several other writers. He states: "From a comparison of the surge of racial nationalism and open warfare in parts of Africa and Asia or the retreat of superordinate migrants from the former Dutch East Indies and French Indo-China, on the one hand, with the fusion of populations in many nations of Western Europe, or the "cultural pluralism" of the United States and Swltzerland, on the other, one must conclude that neither conflict nor assimilation is an inevitable outcome of racial and ethnic contact."

11. Assimilation as a Process Involving Complete Identity As noted above, Park tends to relate assimilation with "visibility". That is, when the immigrant is no 
longer distinguishable from the native in terms of dress, manners, speech, etc., he can, in one sense of the word, be described as assimilated. Thus it would appear that, for Park, it is a prerequisite of assimilation that the immigrant should become, externally at least, identical with members of the host society. However, he finds even this extent of 1dentity inadequate. Later in the same article, Park questions whether visibility can be taken as the sole criterion of social assimilation. "It cannot...... be assumed that the associations which have erased the external signs of race and nationality have modified to any great extent fundamental cultural and racial characteristics." He then goes on to ask whether "the assimilation that is measured in external uniformities of manners, dress and speech may safely be taken as an Index of national solidarity, or whether it may in fact represent a more superficial "like-mindedness", a mere veneer covering profound and more or less Irreconcilable cultural differences." He concludes, therefore, that "an allen may be said to be assimilated, not when he has learned to use the language, customs and institutions of his adopted country, but when he has been able to make them his own in some more thorough-going way than mere use implies."

At first sight, this may seem, not only to contradict what Park said earlier, but also to be more than a little mystical. If the immigrant is indistinguishable 
from the native and thus receives identical treatment, it is difficult to see what else he must do to become socially assimilated. Part of this difficulty arises from the fact that Park treats social assimilation as a unitary phenomenon. Granted that, in his definition, he speaks of the "process or processes" involved in assimilation, but in the body of the article he is concerned with assimilation merely as a single process. Borrle on the other hand, distinguishes between social, cultural, and economic integration, and, leaving aside for the moment any discussion about the differences, if any, between these two terms, it would seem that much confusion could be avoided had Park made a similar threefold distinction with regard to the concept of assimilation. It would then be possible to describe an immigrant who has adopted the speech, dress, manners, etc. of the host soclety to such an extent that he is indistinguishable from the native, as being completely assimilated socially, and still make the reservation that he is not fully assimilated culturally until he has accepted as his own the deeper cultural values of the soclety.

However, although this would clear up certain inconsistencies in Park's approach to assimilation, his theory that assimilation involves complete identity would still be open to criticlsm on other grounds. Several later writers have taken the view that, for an immigrant to be assimilated, he need not, necessarily, 
be indistinguishable from the native even with respect to speech, manners, dress, etc., let alone have made these "his own in some more thorough-going way than the mere use 1mplies." They suggest that the 1mmigrant may adopt those attributes of the host soclety which are essential to national solidarity, a factor which looms very large in Park's writing on the subject of assimilation, and to his adjustment to the society, both socially and economically, and yet still retain those aspects of his pre-emigration background which are not relevant to these ends. According to Park, such an immigrant, would not, by definition, be completely assimilated. And yet, noone would suggest, for example, that the New York Irishman's retention of an Irish inflection in his accent and certain aspects of his cultural heritage makes him any the less a patriotic American. Or, to turn to a non-immigration situation for a moment, no-one would suggest that we have an "assimilation problem" in Britain simply because it is often possible to distinguish a Scot because of his accent and the fact that he may wear a kilt occasionally.

A study by Useem and Useem (1945) of two generations of Norwegian 1mmigrants in a Prairie town and a Prairle farming community is highly relevant to both these points. It demonstrates the extent to which assimilation may proceed at different rates in different spheres, and also the extent to which an immigrant group may become adjusted 
to and accepted in a host community without abandoning their original cultural background in many respects.

Both the urban and the rural Norwegians are described by Useem and Useem as being, with a few exceptions, middle class, by which they imply not only an economic status but also "a system of values, modes of living and an orlentation to life itself." However, both groups show considerable in-group solidarity, albeit to a greater extent in the rural community. Over threequarters of the two rural and the older urban generations, and slightly under two-thirds of the younger urban generation, regard stemming from a Norwegian family as a prerequisite for a marriage partner, and more than ninety per cent of all four groups place membership of a Lutheran church as a first essential in the selection of a mate. In entering into economic associations, such as employment relations, financial transactions and trading, only one in four indicated that ethnic background was an irrelevant factor. Bvery person in the sample claimed formal affiliation to the Lutheran church. A substantial majority are aware of the presence or absence of other Norweglans in any group. And, what is more important, Useem and Useem claim that in Pace-toface contact with non-Norwegians, they display little insight into the norms and motives for action of the out-group. This, they suggest, is because, unlike such minority groups as the Negro, the Jew, or the Indian in America, the Norweglans were not and are not inferior 
socially or economically and, consequently, have not been forced to study the ways of the dominant population in order to cater to or compete with them.

The result of this, according to the Useems, is that, although the Norwegians may be said to be "acculturated", this certainly does not mean that they are "assimilated" in the original sense of the concept. "Because they have succeeded in making satisfactory economic adjustment the sine qua non of Judging groups in American society their deviations will be viewed as ethnic eccentricities or minor irritants. If the same attributes occur in say, the Negro, they are viewed as traits causing social problems. It is the very fact that the Norwegians are only superficially integrated with the out-group that permits them to retain as much of their cultural heritage as they do and still not come into conflict elther with others or amongst themselves. Thus while the Norwegians will be externally functional members of the larger society, they will have an intra-group life which is unique."

Thus the Useems present us with an example of an ethnic group which has neither a) occupied an inferior position in the social structure, nor b) possessed a culture in conflict with other groups, nor c) been distingulshable by its physical appearance, and yet has maintained its in-group unity and achieved a working relationship with respect to both its cultural heritage and the way of life of the receiving country. They suggest that other minority groups will, in like manner, persist as a more or less permanent 
part of the social order, and conclude that: "To study such a social order along the traditional lines of the 'assimilation cycle' or minority groups in the throes of exploitation or conflict removes sociological studies from the essential realities of what is happening in at least one section of contemporary America." i11. Assimilation as a One-Way Process In common with Fairchild, Park not only believes that assimilation involves identity between immigrant and native, but also that the identity is achieved by the immigrant adopting, in a wholesale manner, the culture of the native without the native, on the other hand, adopting any of the culture of the inmigrant. Park does not stress this point to the extent which Fairchild does, but it is nevertheless evident in his writings. He states (1936), for example, that in a modern complex soclety, assimilation becomes "merely a more generic and abstract concept for which Americanisation, and verbs like 'Americanise', 'Anglicise', 'Germanise' are merely more specific terms. All these are intended to describe the process by which the generally accepted social customs and political ideas and loyalties are transmitted to an adopted citizen." Several later writers, on the other hand, have argued that the imnigrant may have a considerable effect on the culture of the host society. Berry, for example, agrees with Fairchild to the extent that in the process 
of assimilation, one society "sets the pattern." In America, for example, the pattern was set by the British colonists and it was to this pattern that the other ethnic groups - German, Italian, Greek, Negro, Chinese, etc. - have adapted themselves. Berry argues, however, that although these groups have adapted more to the culture of the host soclety than the host society has adopted their culture, their contribution to the culture of the United States has been by no means negligible. He states: "Most of the contributions have become so thoroughly integrated into our culture that we do not suspect that they are relatively recent aditions. Grimm alfalfa was introduced into Minnesota by an Immigrant who brought the seed with him from Germany; it was Germans who did so much to develop pure-bred horses, cattle and hogs; Mennonites who came from Russia to Kansas brought with them hard wheat; Russian and Ukrainian farmers brought Kherson oats; Hungarians planted the first Tokay grapes in California; Danes developed the dairy industry; Germans introduced sauerkraut and frankfurters; Italians spaghetti." W1th regard to non-material culture, Berry states that: "Much of our interest in music is doubtless attributable to the influence of our German, Jewish and Italian immigrants." Similarly, in the realm of popular music, the influence of the American Negro has been overwhelming. The "beat" music performed by both 
white and coloured artistes which has dominated the "hit-parades" on both sides of the Atlantic since the early 'fifties, is a popularised form of "rhythm and blues", a music previously performed by Negroes and almost entirely for Negroes.

Assimilation, therefore, can hardly be described as a one-way process.

(b) Subsequent Modification of the Assimilation Concept One reaction to the above fallacies in the theories of assimilation put forward by earlier theorists such as Park and Fairchild has been to retain the concept, but in a considerably modified form. Berry, for example, defines assimilation as "the process whereby groups with different cultures come to have a common culture." For Berry, this means "not only such 1tems of the culture as dress, knives and forks, language, food, sports and automobiles, which are relatively easy to appreclate and acquire, but also those less tangible items such as values, sentiments, ideas and attitudes." He concludes, therefore, that: "Assimilation refers to the fusion of cultural heritages." In contradistinction to the earlier theories, he maintains that this process of fusion is, 1) not inevitable;
2)
a reciprocal process;
3) a slow process of uneven pace; and 4) both a conscious and an unconscious process. As most of these points have been examined previously, it will not be necessary to examine them here.

One further point of difference between the earlier and later assimilation theorists is, however, worth noting. Whereas 
Park and Fairchild seem to think that complete uniformity of immigrant and host is essential in the interests of national solidarity, later writers tend more to the opinion that cultural pluralism, in spite of the concomitant dangers of segregation and discrimination, is a more desirable form of immigrant/host adjustment. The position with regard to the different viewpoints relating to the most desirable form this adjustment should take is summed up by Robin M. Williams. W1Iliams (1957) suggests that there are three types of goals towards which programmes for the reduction of intergroup tensions are aimed. At one extreme there is the assumption that the final goal is the complete acculturation of different ethnic, or more rarely racial and religious groups, into one relatively homogeneous set of beliefs and behaviour patterns. The opposite view visualises a mosaic type of soclety in whlch many separate groups maintain the1r cultural characteristics and in which there is a minimum of contact among the different groups. Somewhere between these contrasting points of view, Williams suggests, is the orientation known as cultural pluralism or "cultural democracy," which envisages an end-situation in which 1) a considerable portion of the cultural distinctiveness of the different groups w1Il be retained, but 2) there will be extensive interaction among all groups, and 3) at least some minimum body of shared values and traditions will be emphasised. Williams concludes:

Recently, there has been more and more serious questioning of both the possibility of actually 
Eradicating differences in any near future and the value of such a goal, even if it could be achieved. To many, the melting pot has begun to represent flat uniformity imposed by a dominant group. The persistence of existing cultural differences has been recognized as bound up in many ways with fundamental sources of individual and group integrity. At the same time workers in the field of intergroup relations have seen the impressive growth of extensive intergroup contacts in an industrial, urban, secular, mobile society. Intergroup problems have become less sharply localized. Physical separation of groups has become more difficult to maintain. Aside from other factors,.... these facts in themselves have cast serious doubts upon even the feasibility of a mosaic-type society. Thus, in effect, doctrines of cultural pluralism have represented a compromise solution, consclous or unconscious, to the dilemmas just sketched.

Not all assimilation theorists, however, have accepted this compromise. At a conference on the cultural assimilation of immigrants held in 1949, Brunle (1950) defined assimilation as follows:

What does assimilation mean? ..... The best French dictionaries define it as meaning, 'the act of making alike'. Applied to an individual the meaning of 'alike' is 'similarity between his way of living and that of another person'. The notion of assimiiation is thus opposed to that of differentiation or separation.... Thus an 1mmigrant appears to be assimilated when the bonds of his old country have lost all hold on him, when he feels a whole-hearted citizen of his new community, when he speaks its language, adopts its ways of $11 f e$ and thought, and when a practised foreign eye no longer detects any difference between his outlook, habits and behaviour and those of his new fellow citizens. 
At the same conference Mauco (1950) took an entirely different point of view:

Assimilation consists in taking a free part in communal life .... This definition .... is elastic enough to allow for all degrees of assimilation, including those compatible with the survival of languages, as in Switzerland, or of sectional interests in certain districts, as in various countries.

Disagreement over the definition of assimilation arose once more in the final discussion of the conference. According to Glass (1950) this discussion turned lastly upon whether assimilation was or was not a bilateral process during which there is exchange between the immigrants and nationals of the receiving country. Some said that there was a mutual exchange, others that cultural assimilation was, by definition, a one-way process, comparable to biological assimilation. However, no final agreement was reached.

Because the term assimilation has tended to retain some of its earlier connotations and in some cases is still used in its earlier sense, some writers have rejected it altogether and attempted to find alternative concepts. The two main terms which have tended to replace assimilation are "absorption" and "integration". We will examine each of these in turn. (c) Eisenstadt's Theory of Absorption The concept of absorption plays a central role in the theory of immigration put forward by Eisenstadt (1954). As this is one of the most ambitious theories to be developed in 
this field in recent years, it is worth examining in some detall. According to Elsenstadt, the migrant is motivated to leave his original. society because his aspirations there are frustrated. He therefore tends to develop definite expectations concerning the role he will fulfil in his new society. The extent to which the migrant achieves his ambitions, Bisenstadt states, w1ll largely depend upon the social structure of the receiving society. That is, upon whether:

(1) the roles open to him are limited, (e.g. by deliberate segregation or monopolising of power positions on the part of old inhabitants); and,

(11) the absorbing society is prepared to accept only those changes which the immigrant desires to make. In spheres of his life where the migrant has not experienced frustration, the migrant may remain attached to his original culture. He may, for example, migrate to avold economic frustration, but remain attached to his original forms of family organisation. Where those aspects of his original culture which the migrant wishes to retain are incompatible with the norms of the recelving society, absorption may be impeded.

The process of migration, Eisenstadt states, is one involving wide social changes. On the part of the migrant, it entails a shrinkage of his field of social participation to that of one or two primary groups, whilst the reference groups towards which the Individual and the small groups were related 
largely disappear. In Elsenstadt's view, therefore, "the process of social change inherent in most migratory movements ultimately involves not only the attainment of specific goals or patterns of cultural gratification, but also, and perhaps mainly, a resocialisation of the individual, the reforming of his entire status 1mage and set of values." On the part of the host society, the absorption of a significant number of immigrants involves changes in at least some parts of the country's institutional structure and in the relative distribution of different elements of the population among the various institutional spheres. The evolution of a new institutional structure, E1senstadt argues, is a lengthy process and thus cannot immediately obliterate the distinct culture of the immigrant groups. In the short run, at the most, it merely transforms them and incorporates them within itself.

Elsenstadt therefore rejects the thesis that the less the Immigrant stands out in his new society, then the more complete his absorption. Complete dispersal of the migrants within the main institutional spheres of the absorbing society might hold good as an index of absorption from the purely loglcal view, he states, but in practice it can be found fully operating only as a limiting and very exceptional case. Instead there usually develops "a 'pluralistic' structure or network of sub-structures, 1.e., a soclety composed to some extent of different sub-systems allocated to different immigrant ('ethnic') groups - groups maintaining some degree of separate identity." Using Linton's terminology, Eisenstadt suggests that in 
any society there are several distinct types of roles "universals", "speclalities", and "alternatives". The universals are incumbent on all members of the society, the specialities only on some particular groups and the alternatives offer a choice to all members. Total institutional dispersal (1.e., complete merging) of 1mmigrants within any absorbing society would imply that they are allocated and perform all the universal roles, are absorbed in more or less equal proportions by the various special particularist groups, and that all the alternatives are open to them. As noted above, however, this is very unlikely to happen. Whilst almost always some demands are made on the immigrant to learn roles which are universal in the absorbing country, there need be no such demand or expectation with respect to many secondary alternative roles, and the immigrants may not only be permitted but also encouraged to remain distinct from the older inhabitants in these spheres.

Viewed in this 11ght, Eisenstadt suggests, the mere existence of a distinct immigrant group with different patterns of behaviour, values and so on, is not necessarily a negative index of absorption. What is more important is the extent to which the structure of such a group is balanced with respect to the total social structure. Several criteria for such a "balanced" relationship are advanced. From the point of view of the society's social system, Bisenstadt states, an ethnic group may be said to be "balanced" in so far as (1) 1ts internal status structure is not completely opposed to that of the absorbing society, but has at least some basic premises in 
common with 1t; (i1) the additional status premises of the ethnic group are accepted as legitimate within the society; and (1i1) the Immigrants accept the status positions allotted to them. Similarly, as far as the ethnic group is concerned, such a balance can be maintained in so far as its members perform the universal roles of the society, 1ts particularist tendency agrees with the normative premises of the absorbing soclal structure, and 1 ts structural peculiaritles fall within the legitimate institutional limits of the society.

This pluralistic approach, Elsenstadt concludes, reformulates the main problem of the comparative study of absorption. Instead of looking for universal indices of total absorption we can focus our attention upon the following questions :

(1) What are the types of pluralistic structure that arise from different types of 1mmigration?

(11) What, in various socleties, are the limits to which pluralistic structures may develop without undermining the basic social structure?

As we will see later, these questions have considerable relevance to the adjustment of Asian and West Indian Immigrants in Great Britain.

\section{(d) The Concept of Integration}

Finally, we turn to the concept of integration. In his report on the Unesco Conference on the Cultural Integration of Immigrants, Borrie (1956) states that in recent years "there has been a growing awareness of the persistence of the cultural traits 
which immigrants bring with them, of the significance of the retention by the immigrants of many of these traits as a stabilising link between their old life and their new, and of the sheer unwisdom of trying to force the immigrants into a world which they do not understand and which oversimplifies the complexities of the social and cultural structures of the nations which have received them." The reaction against assimilation as a concept of cultural uniformity has not, on the other hand, led to a doctrine of laissez-falre. Rather, Borrie states, has it been towards a policy which aims at achieving uniformity where this is felt to be necessary in the interests of the receiving society and cultural pluralism where this is essential to the welfare of the immigrant. To differentiate this newer concept of conformity within a framework of cultural pluralism from the older definition of assimilation, Borrie suggests the term integration.

The assessment of the newer concept made at the Conference by William Bernard (see Borrle, op. cit.) conveys many of its advantages and $1 \mathrm{~s}$ worth quoting in detail.

To say that 'integration' is a happier and more exact term than others to describe the successful inclusion of a new group into a new society is not idle pedantry. The older term 'assimilation', besides its misleading blological connotation, implies a one-way street in group relations. It suggests that the newcomer is divested of his old culture completely and is virtually remoulded in everything from clothes to ideology. It denies or ignores the many gifts brought by the immigrant to his new home, and the impact of his 1deas, his talents, his hopes upon the community which has 
admitted him.

The fact of the matter is that the United States has not assimilated the newcomer nor absorbed him. Our Immigrant stock and so-called 'native' stock have each integrated with the other. That is to say that each element has been changed by association with the other, without complete loss of 1 ts own cultural identity, and with a change in the resultant cultural amalgam, or civilisation if you will, that is vital, vigorous, and an advance beyond 1 ts previous level. Wi thout becoming metaphysical let us say that the whole is greater than the sum of its parts, and the parts, while affected by the interaction with each other, nevertheless remain complementary but individual.

It w1Il be apparent that this concept of integration rests upon a bellef in the importance of cultural differentiation within a framework of social unity. It recognises the right of groups and individuals to be different as long as the differences do not lead to domination or disunity.

There was, however, still some argument concerning the terminology to be used in order to denote what we have called, for want of a neutral term, the process of immigrant/host adjustment. Whilst the majority agreed with the word integration as used by Bernard above, there were some, e.g., Neiva and Diégues, who still used the term cultural assimilation. Nevertheless, there was, according to Borrie, general agreement on the concept of plurality plus adjustment, of a process towards unfformity at some levels but preserving differences at others. It was further recognised, he states, that the concept of accommodation was essential to the process. "The process of 
adjustment was seen as one which is generally accompanied by sub-groups being accommodated w1thin the total framework, while wholly or partially absorbed in various sectors or isolates of that framework. Hence there may be economic absorption, but cultural plural1sm; cultural absorption at some levels (e.g., clubs and socleties), yet cultural differentiation at other (e.g., family customs, diet, etc.).... and so on through many permutations which arise because of variations in the social systems brought into contact through immigration."

Finally, Borrie concludes that although the ultimate aim of the immigrant recelving countries may be the merging of immigrant and native cultures, this is now recognised to be a very long process taking generations rather than years, the important and more immediate problem being the degree of adaptation which can reasonably be expected from the first generation and at what levels it should occur.

It will immediately be apparent that for all practical purposes the concepts of absorption, as used by Bisenstad, and integration, as put forward by Borrie and Bernard, are identical. Both admit the likelihood of the culture of the immigrant affecting that of the host society, both recognise the Inevitability and the value of some degree of cultural pluralism and both stress that the precess, by whatever name it is called, is a ver.y long-term one. Nevertheless, the concept of integration has two main advantages over that of absorption.

Firstly, the term absorption is itself far from being 
neutral. The Chambers Twentieth Century Dictionary, for example, defines the verb "to absorb" as "to suck in: to swallow up: to imbibe: to take in: to incorporate: to take up and transform (energy) instead of transmitting or reflecting: to engage wholly", which is only a little more free of physiological implications than is assimilation. It is, perhaps, in view of this fact that Bernard claimed that Immigrants to the United States had not been "absorbed". The verb "to integrate", on the other hand, defined (op. c1t.) as "to make up as a whole; to make entire: to find the integral of: to find the total value of" is refreshingly free of any blological connotation. Secondly, in addition to avolding the drawbacks of the term assimilation, the concept of integration has certain positive advantages with regard to the present study. The term integration, unlike that of absorption, has gained considerable currency in the United States and more recently in Britain, in the study of race relations. This gives us the not insignificant advantage of being able to use the same terminology in both the main spheres with which we are now concerned: race relations and immigration theory.

To conclude, therefore, it would appear that the concept of integration is the most convenient for our purposes. The earlier theories of assimilation contained implicit value premises - that assimilation was inevitable, that it involved achlevement on the part of the immigrant of complete uniformity with members of the host society, and that such conformity was both necessary and desirable - which have since been shown to 
be untenable. Whilst it must be admitted that these assumptions have been eliminated from some later theories of assimilation, the term is still used in its former sense by some theorists and is therefore better avoided. Of the two main alternative terms which have been evolved, absorption and integration, the latter is preferred (a) because it avoids the physlological implications of "assimilation" which "absorption" does not, and (b) because it provides a useful link with modern race relations theory.

Nevertheless, it should be noted finally that the approach to the process of immigrant/host adjustment of modern theorists of assinilation and of absorption and integration is remarkably similar. The selection of any one term 1s, therefore, largely a matter of convenience and not a question of choosing the most viable theory. Thus, whilst using the term integration, it is possible to draw upon the theoretical concepts of such writers as Berry and Eisenstadt without modifying their basic orientations.

\section{Theories of Race Relations}

Race relations has often been described as one of the major "social problems" facing the world to-day. By this is meant, of course, "bad" race relations - cases in which discrimination, oppression and conflict occur - although these phenomena are by no means an inevitable result of race and culture contact. The main motivating force behind studies of race relations has been, therefore, a desire to discover what makes for "bad" race relations in order that the information so gained could be used to alleviate the situation. 
Until comparatively recently, the main theoretical concept in the study of race relations had been that of racial prejudice. Although prejudice and discrimination have been recognised as belonging to different orders of phenomena loosely speaking, prejudice is a mental attitude and discrimination a form of behaviour - the emphasis on racial prejudice has been justified on the grounds that it is the cause of the socially undesirable aspects of race relations. Rose (1956a) for example, states:

We use the term prejudice to refer to a set of attitudes which causes, supports and justifies discrimination. Since discrimination itself consists of observable behaviour, it is a more useful subject for study. But since in this article, we are searching for the causes of behaviour, we must direct our attention to the mind of the person who practices prejudice. Prejudice is taken as the mental state corresponding to the practice of discrimination. Now this is an extremely dubious argument. Rose himself later gives personal advantage as one of the causes of prejudice. That is, people may become prejudiced in order to excuse or rationalise economic exploitation or political domination. Thus it is possible to argue that the early slave traders and plantation owners discriminated against the Negro, not because they were prejudiced, but because the institution of slavery had certain economic advantages; and that prejudice subsequently arose as a means of rationalising, justifying and maintaining this advantage. But to accept this argument also means 
accepting the premise that discrimination causes prejudice rather than the other way round. In fact, we need not choose between either of these causal hypotheses. As some writers have pointed out, there is no simple one-to-one relationship between prejudice and discrimination. Banton (1959), for example, shows that prejudice can exist without discrimination, and discrimination without prejudice.

Be that as it may, the main emphasis has been on prejudice rather than discrimination and a wide variety of theories have been evolved in an attempt to explain the phenomenon. A list of such theories would include the following: the "well-earned reputation" theory, the dislike of difference theory, the economic competition theories, social control theories, social norm theories, the unpleasant experience theory, the frustrationaggression theory, the scapegoat theory, symbolic theories and the authoritarian personality theory. Furthermore, some writers have suggested prefudice cannot be explained in terms of any one single factor. Berry (1951), for example, concludes that "race prejudice is a complex phenomenon not to be explained by any single factor. Multiple causality is obviously at work. Most, If not all, of the theories ....... contain at least an element of truth." In addition to these mentioned above, therefore, there are also the multi-causal theories of Zawadski (1948), Rose (1957) and Allport (1951), which attempt to take into account some or all of the various factors.

As Berry states, most of these theories contain at least an element of truth. However the converse is also true: rone of 
the theories constitute, either on their own or in combination with other theories, an adequate explanation of the phenomenon of prejudice. The number of theorles is too great to allow examination of the specific difficulties encountered in each individual case. For this, the reader is referred to reviews of these various theories by Rose (1957), Zawadski (1948), Allport (1951, 1958) and Berry (1951). Nevertheless, all these theories have one defect in common which is worth examining in some detail, namely the inability to account for situational variations in prejudice.

In recent years, much interest has been shown in the relationship between prejudice in different situations. One of the basic questions asked in this type of research is as follows: "Does the reduction or absence of prejudice in one particular situation mean that there will be a similar reduction or absence of prejudice in others?" Some of the major flndings are presented below.

1. Minard (1952) found that, in the Pocahontas coal field in West Virginia, there was almost complete integration in the mines and almost complete segregation above ground. Twent y per cent of subjects were prejudiced in both situations and twenty per cent in neither: the remaining sixty per cent tending to shift their role and status on passing through the mine's mouth into the outside world.

2. Harding and Hogrefe (1952) found that working with Negroes increased willingness to continue doing so, but did not increase willingness to associate with Negroes in other situations.

3. Irish (1952) found that, in general, attitudes of 
neighbours towards Japanese-Americans were more favourable than non-nelghbours, but working with Japanese-Americans did not make any difference to the attitude score.

4. Blesanz and Smith (1951) report that in Panama where there is a divided street, one side of which is racially segregated (the Canal zone side) and the other unsegregated (the Panamanian side), most Panamanians and Americans accommodate themselves to the different social systems without difficulty as they pass from one side of the street to the other.

5. Reitzes (1953) compared the w1llingness of the same group of workers to accept Negroes in two different contexts. As members of an all white Civic Club they refused to admit Negroes into the neighbourhood in which they lived, but as members of a union opposed to discrimination, they supported non-segregation and racial equality in the work situation.

6. Stouffer, et al. (1949) found that the attitude of white army personnel towards the Negro as a flghting man became more favourable after equal status, integrated contact under combat conditions, but their attitude towards the Negro as a social companion did not necessarily change. Anomalous results have been found. McKenzie (1948), for example, found that among college students and workers in a governmental agency, willingness to associate with Negroes in one situation was closely associated with willingness to 
associate with Negroes in others. Nevertheless, the following conclusions do appear to be valid: 1) reduction of prejudice in one situation does not necessarily mean that prejudice will be reduced to the same degree in others; and 2) a low degree or absence of prefudice in one situation does not necessarily mean that it w1ll be absent or equally low in others. Moreover, it has been shown that the degree of prejudice (as measured by the $F$ scale) in two groups may be the same, but the amount of discrimination they practice may differ. On the basis of such tests, Rose (1956b) concludes with regard to the American situation that: "There is no evidence that ...... any known source of 'prejudice' in the psychological sense is any more prevalent in the South than in the North."

These findings have thrown considerable doubt upon the value of racial prefudice as an explanatory concept in race relations. Some writers have suggested, therefore, that the solution to the difficulties encountered in the formulation of an adequate theory of prejudice should be solved, not by modifying existing theories or the formulation of new and more viable ones, but by abandoning the concept altogether. Blumer (1958) for example, states: "The idea so current during the past decade that a racial relationship is sustained by individual feelings or attitudes must be recognised as puerile." Similarly, Rose (1956b) claims that "prejudice has little to do with intergroup relations", and Raab and Lipset (1959) state that "prejudiced attitudes do not determine prejudiced behaviour." Other writers, however, suggest that the swing against 
psychological explanations in race relations has gone too far. Pettigrew (1961) points out that in some of the examples given above, there was some variation: not all miners (case 1) and not all Panamanians (case 2) followed the general pattern, and some whites either approve or disapprove of all segregation. These people, he suggests, are easily explained by traditional theory. They possibly consist of the extremes of authoritarianism: their attitudes on race are so generalised and so salient that their consistent behaviour in racial situations is sometimes in defiance of social norms. Pettigrew admits that the other directed individuals who shift their behaviour to keep in line with shifting explanations present a real problem for psychologists: their racial attitudes appear less salient, more specific and more tied to particular situations. However, he argues that the writers who reject the use of prejudice in race relations have been misled by the over-emphasis on the externalisation function of racial prejudice into underestimating the value of psychological analysis. He states: "These writers employ cultural and situational norms as explanatory concepts for racial prejuaice and discrimination, but fall to see that the conformity needs are the personality reflections of these norms and offer an equally valid explanation at the psychological level." In support of this claim, he cites a study of h1s own (1959), in which he found that Southerners who were male, non-attenders of church, veterans, political independents and lived in communities with relatively small percentages of Negroes, were less prejudiced than their 
counterparts. "In short," he concludes, "people who are more likely to conform are more likely to be prejudiced."

A similar argument is put forward by Allport (1962) He admits that "societal forces - social settings, situational forces, demographic and ecological variables, legal and economic trends - are the distai causal factors in group relations: from them one can predict, at least roughly, the course of integration and segregation, of accommodation and conflict." At the same time, however, he claims that the intervening factor of personality is the proximal cause of all human conduct, and conformity is the missing link that explains why and how societal forces eventuate into the patterns that they do. Allport further argues that, whilst it would be possible to "leapfrog" from socletal factors and predict the final outcome without taking into account the intervening variable of personality factors, it would be unwise to do so for two reasons. Firstly, a full scientific explanation requires that proximal as well as distal causes should be included in the final accounting. And, secondly, the predictions in terms of history, social forces, or situation, are often rough and inaccurate because such factors do not always affect people in the same way. "In so far as societal predictions fail," he states, "1t is because they overlook the non-conformist, deviant, morphogenic aspects of personal behaviour - of which there are many." Finally, Allport concludes that there are no good reasons for selecting one explanation at the expense of the other: the societal and personality approaches can and should be blended. 
There is much in what Pettigrew and Allport say. It would be foolish to suggest that social norms are not reflected in the personality of the people who act in accordance with them, or that prejudice does not exist, or that the psychological aspects of intergroup relations should be ignored. Nevertheless, the writer would agree with Reitzes (1959) that too much emphasis has been placed on prejudice and personality factors (a fact which he somewhat paradoxically attributes to the high race consciousness of Americans in general) and that the study of race relations should be integrated to a far greater degree into the general field of social science research. For this reason, the concept of prefudice will be little used in the present research and two other concepts, social distance and conflict, employed in its stead.

The concept of social distance was evolved by Park, whose theories we have already examined in relation to the concept of "social assimilation". According to Hill (1953): "It was his notion that the term "distance" could be applied to social relations for a deeper understanding of human conduct by reducing personal and social relations between individuals of differing ethnic backgrounds to measurable terms, so that degrees of intimacy could be easily distinguished." However, It was Bogardus, one of Park's students, who carried out the first quantitative analysis of social distance.

Bogardus' respondents were asked to indicate to which steps on the following scale they would admit members of various ethnic groups. 
1. To close kinship by marriage.

2. To my club as personal chums.

3. To my street as neighbours.

4. To employment in my occupation.

5. To citizens in my country.

6. As visitors only to my country.

7. Would exclude from my country.

Allport (1958) states that "the most striking finding

from this procedure is that a similar pattern of preference is found across the country (the United States) varying little with income, region, education, occupation, or even with ethnic group. Most people, whoever they are, find the English and Canadians acceptable as citizens, as nelghbours, as social equals and as kinsmen. These ethnic stocks have the least social distance. At the other extreme come the Hindus, Turks and Negroes. The ordering - with a few minor shifts - stays substantially constant."

In view of its obvious advantages, it is not surprising that the use of social distance scales should have become widespread. Since its original formulation, Bogardus' scale has undergone three revisions, several other types of attitude scale have been evolved (e.g., the Thurstone, Sletto and Likert, and Guttman scales), and the concept of social distance has been applied to an extremely wide variety of phenomena and in a multiplicity of different ways, too numerous to examine here. "In fact," claims Hill, "during the 1930's and the early $1940^{\prime}$ 's the term took on a fashionable and sometimes faddish 
character. It was used as a social psychological 'catchall' for explaining all facets of intergroup tensions." In recent years, however, the concept has been subjected to more critical analysis.

We shall not here be concerned with the various technical criticisms which have been levelled at particular social distance scales, but rather with the validity of the basic assumptions on which the concept is based. With regard to the latter question, the main criticism has been that the results of social distance testing cannot, as was at one time thought, be interpreted solely in terms of the attitudes of individuals and their Image of the stranger group. Krech and Crutchfield (1948) suggest, for example, that existing tests of social distance seem to include two different types of reaction on the part of the individual: 1) his relative willingness or unwillingness to be exposed to the object, and 2) his relative willingness to be identified with the object. They conclude: "Social distance is a complex quality related in the most intimate way to the ego standards of the individual, his conception of prestige in the eyes of the group, etc. Even though a man may hate the English ...... he may not reject them as residents in his own street."

Similarly, Banton (1960) concludes that "beyond question ...... social distance may spring from a variety of sources, not all of them social." Whilst admitting that social distance may arise from people's negative attitudes towards a particular group, he suggests that at least three other factors 
may be involved. (1) Social distance may be a characteristic of certain types of social relationships, notably those between superordinate and subordinate, and between people of comparable social standing, but potentially conflicting obligations. (2) Soclal distance may reflect a relative lack of common interests or experiences. (3) Social distance may equally well be caused by self-interest springing not from an individual's personality but forced upon him by his social position, e.g., two people may be rivals and each may avoid the other in order to convey an impression that he is superior.

Finally, Mozell H1ll (op. clt.) suggests that the main fallacy in social distance studies has been the use of attitudes as "causative agents" determining the individual's behaviour towards others. He states that, instead of this, attitude studies should be used in an attempt "to get at the cultural, societal and psychological orientations of the individual, characterized by his total conflgural mobilization with reference to the whole sltuation towards which he behaves." Hill finds social distance scales inadequate for this purpose because "the number of situations involving attitudes are so infinitely varied and complex that it is essentially futile to attempt to standardize descriptive classifications of them." He therefore recommends the retention of the concept of social distance as a mental construct or "heuristic device", but suggests that it should be examined by less rigid methods such as the focused interview or projective techniques, rather than attitude scales. Now 1t so happens that this is largely the manner in which 
the concept of social distance will be used in the present study. However, it should be pointed out that this did not arise from any belief on the part of the writer concerning the inadequacy of social distance scales, but rather from the difficulty of carrying out such tests on an adequate cross-section of respondents, owing to the problems of access outlined in the Introduction. The fact that attitudes can no longer be used as causal agents does not mean that social distance scales are of no value. Even though such scales may not measure social distance as such, it is quite legitimate to posit that they give a reasonably close approximation to it. As Lundberg (1939) states: "the laws of physics are not only circumscribed in their applicability, they usually describe behaviour which occurs nowhere in the natural uncontrolled universe, but under the assumption of no friction, or under ideal or theoretical conditions." In the same way, tests of social distance under laboratory conditions, e.g., Triandis and Triandis' (1960) cross-cultural study of the effect of different factors such as race, social class and religion upon social distance, provide useful information which could not be obtained by use of focused interview or projective techniques, even though all the factors operating in the "real world" may not have been taken into account.

Given that social distance is a valid concept, providing that it is admitted that factors other than attitudes and the Image of the stranger group are involved, what then are the advantages of this approach over the use of the concept of 
prejudice? These seem to be threefold. Firstly, the concept of social distance is affectively neutral. To say that person A. is prejudiced carries overtones of censure and it is desirable that this should be avoided in the interests of objectivity. Secondly, the concept of social distance has wider application in the study of intergroup relations and therefore permits the integration of findings in race relations into social science research in zeneral. For example, there may be similarities between the relations between races and the relations between members of different professions or different departments of the same industrial organisation, and whilst it would be possible to use the concept of soclal distance in both cases, the use of the term prefudice tends to be restricted to the former. Thirdy, the term prejudice tends to be restricted to cases where there is hostility involved. But, as Banton has pointed out, social distance may arise from mere strangeness between participants in a social relationship without there being any hostility involved.

In order to examine this latter point further, we must digress for a monent and give some details of a distinction made by Park and Burgess (1924) between two types of social interaction which distinguish primary relations from the more formal sort of relations. In the primary relations, they suggest, the person is treated as unique, and the relationship is based upon empathy, or "sympathetic contacts". Between strangers, however, there is less possibility of knowing the individual characteristics of the other person, and one is forced to make 
some kind of guess about what kind of person he is - that is, one generalises on the basis of the category the stranger seems to belong in. On the basis of this distinction, Faris (1953) makes an important point. He states: "There has been a tendency in some race relations literature to regard the categoric type of relation as unfair and somewhat abnormal. In our relations with persons not well known to us, however, we can do nothing but deal with them as representative of a category. .... The defect in the case of race relations lies not in the use of such categories, but in the erroneous use of the principle. Apart from such Inapproprisis uses, however, the categoric type of relation is necessary and normal for a large amount of social intercourse in formal relations."

Now in such situations, it would seem reasonable to state that there was social distance between the two participants. Because of the absence of hostility, however, it would be inappropriate to say that prejudice was involved. But such a relationship is very likely to arise when the two participants are of different races. Thus, unless one is to posit two types of prejudice, one hostile and the other non-hostile, which could easily lead to confusion as it has mainly been used in the former sense, the concept of prejudice is inadequate for the analysis of a large part of intergroup relations.

On the other hand, it is quite in order to use the concept of social distance in relation to either the stiff, formal relationships between strangers or the cases where host1lity is involved. In either cases, social distance is high, but for 
different reasons. It would, of course, be possible to use the concept of prejudice in relation to the hostile forms of relationsh1p, but here again 1 t is limited in use, because there are causes of hostlilty other than prejudice. For this reason the concept soclal conflict will be employed. Ruth Benedict (1943) has stated that in order to understand race conflict, we need to understand conflict and not race. Nevertheless, there has been a tendency for the study of conflict to be neglected. In 1950, Bernard stated that: "In the last two or three decades interraclal sociology has suffered relative to cultural sociology in the U.S.A. The sociological theory of conflict, for example, remains essentially where Simmel left 1t." Since this article was written, however, Coser (1956) has undertaken a systematisation and revision of Simmel's theory and related it to present day affairs. We cannot, of course, examine this theory in all 1ts aspects, but we will outline its essential attributes in relation to the requirements of the present study.

For Coser, conflict is not necessarily dysfunctional in that it serves to establish and maintain the identity and boundary lines of soclety and social groups. "Conflict with other groups," he states, "contributes to the establishment and reafirmation of the identity of the groups and maintains its boundarles against the surrounding soclal world." Even within the groups, he clalms, conflict need not be dysfunctional. Without ways to vent hostility towards each other and to express dissent, group members might feel completely crushed and might 
react by withdrawal. Thus by setting free pent-up feelings of hostility, conflicts serve to maintain a relationshlp.

However, where such conflict might be dismuptive, social systems provide for specific institutions which serve to drain off hostile and aggressive sentiments. These safety valve functions serve to maintain the system by providing substitute objects on which the hostile are displaced, as well as providing a means of abreaction. Through these safety valves, the hostility is prevented from turning against its original object, but the release of hostile sentiments on a substitute object creates a new conflict situation. This leads to a distinction between "realistic" and "unrealistic" conflict.

According to Coser, each social system contains sources of realistic conflict in so far as people raise conflicting claims to scarce status, power and resources, and adhere to conflicting values. Realistic conflicts arise when men clash in the pursuit of claims to these scarce commodities. Nonrealistic conflicts, on the other hand, arise from deprivations and frustrations stemming from the socialisation process and from later adult role obligations, or they result, as we have seen above, from the conversion of originally realistic conflict which was disallowed expression. Whereas the first type of conflict takes place w1th the frustrating agents themselves, the second consists of a release of tension in aggressive action against shifting objects. The first type of conflict is viewed by the particlpant as a means of gaining realistic ends, a means which might be abandoned if other means appear to present a more 
effective way of reaching the same goal. The second leaves no such cholce, however, since satisfaction is derived from the aggressive act itself.

This approach to intra- and inter-group relations has several advantages for the student of race relations. Firstly, it necessitates the analysis of interracial hostility from both sides. Coser states: "Conflict can only occur in the interaction between subject and object; it always presupposes an Interaction." All too often, however, studies of race relations have been carried out from one side only. They have been concerned with either the prejudice of the majority group or the "problem" of the minority group and have ignored the fact that the characteristics of both groups must be taken into account. Secondly, Coser's stress on the realistic bases of conflict provides a useful counterbalance to the emphasis laid on Irrational factors in such theories as the frustrationaggression hypothesis. Thirdly, Coser's thesis that conflict may not be dysfunctional has practical applications for the reduction of intergroup tensions, as is shown by the following account by Chase (1952).

Communities in Lebanon have a tradition of dreadful feuds, sometimes lasting for generations........... An American sociologist, reared in Syria, decided to make an experiment. He organised a game of volley ball in one of the villages torn by feuds. Young men became interested in the sport, and presently the whole village gathered to watch them play. Members of opposing clans began to talk to one another in the excitement of the game..........The 
sclentist then arranged a match with a neighboring village....... In due time the pattern of feuds collapsed and the village returned to more normal behavior. Observe, however, that conflict did not necessarily disappear. It was transferred to a higher level, against the people of the neighboring village, and in a considerably less dangerous form.

Needless to say, 1t would be nalve to suggest that application of conflict theory to any and all situations would result in such an easy and successful solution of the problem. Nevertheless, it was successful in the above case and it is difficult to see how any theory of prejudice could have been used to predict and mediate such a solution.

In conclusion, therefore, we would suggest that the concept of prejudice has, until recently, been over-emphasised as an explanatory concept in the study of race relations. This is not to say that prefudice does not exist: in face of the evidence to the contrary, this would be foolhardy. However, it does appear that the concept of prejudice cannot be applied to all aspects of race relations whereas a combination of the concepts of social distance and social conflict can. The main advantage of these two concepts is that, unlike prejudice, they do not constitute an explanation of any race relations situation. They are part of the nature of intergroup relations, but do not commit us to any reason for their existence. Once having discovered whether social distance or conflict exist in a particular situation, we can then search for the reasons. It may well be, of course, that prejudice is one of the causal factors, but there may also be others, and the present approach 
leaves us free to search for them.

4. Industrial Integration

Thus far we have been concerned with the general fields of immigration and race relations. However, as the main concern of the present study is the coloured immigrant in industry, it is now necessary to restrict our sphere of interest to this aspect of the general situation.

For this purpose we shall distinguish between three main spheres of integration:

1. Social Integration: measured by the extent to which race or ethnic group membership per se is a factor determining social distance between members of an immigrant or minority group and members of the host soclety.

2. Cultural Integration: measured by the extent to which members of an immigrant or minority group and members of the host society come to have a common cultural heritage, or the culture of the immigrant group comes to be accepted as a legitimate (alternative) reature of the culture of the host society.

3. Economic Integration: measured by the extent to which the immigrant or minority group is absorbed into, and accepted as part of, the economic system of the host society.

It is, of course, with this latter sphere that we are mainly concerned, but in a restricted form in that we are 
interested in integration into industry rather than the economic system as a whole.

For complete integration to have taken place, there would be no social distance between immigrant and host, complete cultural uniformity or acceptance of the Immigrant culture as a legitimate alternative, and complete absorption into industry at a level of equality. As Eisenstadt points out, this is unlikely to occur in the first stages of any immigration movement. The concept of integration as embodying complete equality will therefore be retained only as a limiting case against which 1 t is possible to measure the degree of integration which the immigrants do in fact attain. Where an immigrant group has become a functioning part of the economic, cultural or social system, this group will be described as accommodated; that is, partially, but not fully integrated. These spheres therefore refer to areas of accommodation as well as areas of integration. However, in order to avoid the reintroduction of errors contained in the earlier theories of assimilation, two points need to be made. Firstly, although the stage of accommodation is a prerequisite of integration, it does not follow that an accommodated immigrant group will necessarily proceed immediately, If at all, to the later stage of integration. Like the Norwegians in the Useems example, an Immigrant group may become integrated in one sphere, but remain accommodated in others, perhaps for an indefinite period. Secondly, it must not be thought that integration constitutes a "better" or in some way more desirable form of adjustment. It may well be that an immigrant group would 
prefer to remain only accommodated in some spheres, e.g., social relations. In this case, lack of social integration would not imply discrimination, but would merely be indicative of a desire on the part of the immigrant group to remain within the bounds of 1 ts own social structure.

It is also necessary to point out that the three-fold distinction between the different spheres of integration or accommodation, although necessary to instil some degree of order Into a complex subject matter, is somewhat arbitrary and should not be applied too rigorously. For one thing, there is considerable interaction between the different spheres. For example, a minority group's lack of social acceptance by majority group workers or customers may deter firms from employing them, thus giving rise to inequality in the field of employment. Similarly, lack of social acceptance, by making it more difficult for minority group members to become conversant with the norms, customs and values, may delay their cultural integration. More important for the present study, however, is the fact that at least two of the spheres, namely the economic and the social, appear to overlap. That 1s, the field of social integration extends into the works environment in that social interaction occurs within the informal organisation of Industrial concerns.

For this reason, in addition to differentiating between economic and other types of integration, we shall also distinguish between two types of economic integration; "work integration" and "social integration within the works environment." 
As with social integration in general, the latter is measured by the extent to which race or ethnic group membership per se is a factor determining social distance between the immigrant and the British worker. Work integration, on the other hand, is concerned with the extent to which the 1mm1grant is accorded or has achieved equality with the British worker with respect to the formal organisation. 1

The extent of work integration will be assessed in terms of three criteria: employment level, occupational level, and the treatment of coloured workers by management and supervisors. The first two are derived from Turner (1951) who defines them respectively as "the degree of labour force participation and, for those employed, the level at which participation is attained." Thus we are, in effect, concerned with the quantity and quality of jobs available to coloured workers. Applied to a psrticular firm, these criteria refer to the proportion of coloured workers in the labour force and the proportion of coloured workers in the various jobs at different status levels. Work integration will be said to be greater, the nearer the employment and occupational level of coloured workers approaches equality with that of the white employees. However, whilst it is necessary for the attainment of

1. It could be argued, of course, that the concept of social integration at work is superfluous, being merely a particular case of social integration in general. However, the indications are that this is not the case. In Minard's study, for example, Negro miners in West Virginia were found to be almost completely integrated at work and almost completely segregated in the community. 
work integration that coloured workers should obtain jobs and obtain them throughout the various levels of the status hierarchy, these two criteria do not, in the writer's opinion, fulfil all the requirements for full work integration. For even where equality of employment and occupational levels is obtained, coloured workers may receive unequal treatment in other respects. They may, for example, be given orders with less civility than white workers, be expected to work overtime without notice whereas white workers are not, be given the least wanted jobs within a particular status level, be provided with less adequate facilities than white workers, and so on. Factors such as these will be grouped under the heading of "treatment of coloured workers by management and supervisors." As with employment and occupation level, work integration will be said to be greater, the nearer the treatment received by coloured workers approaches equality with that received by white workers.

It must be pointed out, however, that progress towaràs integration with respect to employment and occupational levels may, under certain elrcumstances, be incompatible with the achievement of equality of treatment. It is concelvable that some firms may employ as many coloured workers as possible, not because they are believed to be better workers, but because they can be accorded treatment much inferior to that which the white worker would be prepared to accept. In popular parlance this is known as using "sweated labour". Where jobs are hard to come by, the coloured worker may well be placed in the position of having to make the first step towards industrial 
integration, the mere obtaining of a job, at the expense of the retrograde step of accepting unequal treatment. In other words, he may be forced to accept accommodation into the industrial system because full integration is not obtainable. A discussion of equality and inequality inevitably brings to mind such topics as racial discrimination, the colour bar and so on. Before going further, therefore, it will be as well to examine the relationship between discrimination and equality. Hankins (1934) defines discrimination as "the unequal treatment of equals." If we accept this definition, it follows that there is no simple relationship between discrimination and lack of industrial integration. For inequality of employment or occupational level to be a sign of discrimination, then the immigrant and the British worker must be equal. However, the indications are that the immigrant worker 1s less skilled than his British counterpart. In this sense, therefore, coloured and British workers are unequal with respect to competitive capac1ty. Thus, a lower employment or occupational level on the part of a paxticular immigrant group may merely be a sign that employers are "discriminating" against the less skilled worker, the fact that he is also coloured being "accidental".

On the other hand, some employers may use the fact that the coloured workers tend to be less skilled as an excuse for not employing them, or for employing them only on lower status jobs. Hankins states that discrimination may also exist where competitors are unequal, but the burdens or advantages are disproportionate to the inequalities. Thus, where coloured 
workers have a lower employment or occupational level than would be expected in relation to the difference in skill level between white and coloured workers and this results from action on the part of management, then discrimination w1ll be said to exist. However, it should be pointed out that disproportionately low employment or occupational levels may occur through reasons other than managerial discrimination. Firstly, the mere fact that the coloured immigrant is a stranger, not conversant with the full range of jobs available to him, may lead him to accept a job of a lower standard than his capabilities would merit. Secondly, discrimination in spheres other than employment may limit the range of jobs open to coloured workers. Any restriction of coloured people to particular residential areas as the result of discrimination in housing, for example, will at the same time have the effect of limiting the coloured worker to those jobs which are within reasonable travelling distance of these areas.

Thus, where there is inequality of employment or occupational level, we need to know three things before we can assert that discrimination in employment has taken place: firstly, the relative skill level of the white and coloured workers; secondly, whether the inequality is out of proportion to the difference (if any) in skill level; and thirdly, whether the inequality resulted from action on the part of management.

In the case of inequality of treatment by management and supervisors, however, none of these considerations apply. Firstly, this type of inequality by definition results from action on the part of management, and secondly, the question 
of skill level is only relevant to whether a man is employable or not, or whether he is capable of being promoted. Once employed or promoted, management has in effect admitted that the man is of an adequate skill level and there is, therefore, no further justification for according him treatment different from that which a white worker would receive.

One further point arises. It can be argued that it is wrong, not only for coloured workers to be treated differently from white workers, but also that it is wrong for coloured workers to accept such inequality of treatment, that by accepting a position in a firm which used "sweated labour" they are in fact perpetuating the system. However, as noted above, it may be that in some cases the coloured worker will be able to obtain a job only because he can be treated differently from white workers. Under these clrcumstances, the coloured worker may argue that it is better to have a poon job than no job at all. We shall not go into such moral considerations here, but merely note that either a low employment or occupational level or inequality of treatment of coloured workers is a sign that full integration is lacking, without attempting to stipulate which is the "better" state of affairs.

In this section, we have been concerned with levels of integration in different industrial spheres and the criteria by which these may be assessed. Little has yet been sald of industrial integration as a dynamic process. Following Eisenstad's formulation, we shall regard the process of 
integration as being, in large measure, the outcome of an interaction between two sets of predisposing factors - the characteristics of the migrant group and the characteristics of the receiving situation. This approach will be developed further in Chapter Three, but first we w1ll give a general outline of race relations in and coloured immigration to Great Britain. 


\section{CHAPTER TWO}

THE BRITISH RACIAI SCENE

Preliminary Summary

Having discussed the study of race relations and immigration in general terms, we now turn to a more detailed examination or British experience in these fields. Following a short historical introduction (section 1) and some detalls of the post-war growth of the British coloured population, (section 2), the present chapter falls into two main parts. Section 3 is concerned with the life and adjustment of coloured people in Great Britain, both in the sea ports in which they originally settled and in the industrial towns towards which later immigration was directed. Here we shall make an important distinction between tiee orientation of the West Indian 1mmigrants who, in general, desire integration into British society and that of the Asian (Indian, Pakistani and Arab) group who tend to prefer to remain within their own communities. Section 4 examines the various theories which have been developed in an attempt to explain the pattern of race relations in Britain. In this country, it will be argued, the concept of racial prejudice is perhaps even less useful than elsewhere (e.g., the United States), and the various manifestations of social distance between British and coloured people will be examined in terms of differences in norns and values, beliefs concerning the social status of coloured Immigrants, the lack of clearly defined norms of conduct towards them, and so on. 
1. Historical Background

The first known coloured inhabitants of Great Britain were Negro slaves introduced during Elizabethan times. ${ }^{1}$ Though their numbers were at first small, the coloured population grew steadily from the latter part of the seventeenth century as it became a fashion, first amongst the nobility and later amongst planters returning from the tropical settlements, to have Negro slaves as servants. By the $1760^{\circ} \mathrm{s}$ it was estimated that there were at least some 14,000 Negro slaves in Britain.

In 1772, however, the Mansfield judgement rendered the institution of slavery untenable in this country and thereafter the Negro population seems to have declined considerably. Though many of the former slaves remained with thelr masters as paid servants, the practice of having coloured servants largely died out in later years. Of those who left their masters to live their own life, a large proportion, lacking any trade or skill, became destitute and for a time the Negro beggar was a common sight in London. Some of these men were settled in Sierra Leone, others emigrated to the West Indies, and over the years the remainder elther died or were merged Into the general population. By the $1870^{\prime} \mathrm{s}$, according to a contemporary report, ${ }^{2}$ apart from a few crossing sweepers, the Negro had virtually disappeared from the scene.

During the same perlod, however, the coloured population of Great Britain was being augmented from other sources, One

1. Th1s section is based mainly upon Little (1948) Chapter 7. 2. Quoted Little, op. cit. page 191. 
such group, the coloured students, is only of marginal interest to the present study. More important, on the other hand, were the Lascars from the East Indies and the Chlnese seamen who, throughout the nineteenth century played an increasingly important part in the manning of British merchant ships. "These men," according to Little, "were brought over in East India Company ships, and on arrival in the Thames were discharged and left in London for some time before shipment on the return voyage. In several respects they were at a disadvantage compared even with the Negroes. Ignorant of England and Bnglish ways, they were exploited by each other, and by the worst products of the riverside slums of Wapping, Shadwell and Poplar."

At this time, Negro sallors and ex-sailors also began to settle in the London dock areas, and towards the end of the nineteenth century, Banton (1955) tells us, a small Negro settlement grew up near the docks in Canning Town. However, it was not unt1l the 1914-18 war that the next big influx of coloured immigrants to this country occurred.

According to Little; "Several thousands of coloured labourers were brought over to do work which would free Englishmen for combatant service. They worked in munition factorles, in labour battalions, and also filled the places of many whlte merchant seamen who were transferred to the Royal Navy." In adaition, coloured seamen were left in Britain when the ships on which they were employed, e.g., on the West African routes, were requisitioned for transport 
service by the government. Others deserted or left their ships to take up work ashore at the current high rates of pay, and still others worked their passage to Britain having heard of the opportunities for employment here.

Following the cessation of hostilities, however, the coloured workers in the war industries and related forms of employment found themselves out of work. Furthermore, their numbers were augmented by the coloured labourers from the labour battalions which were demobilised in Britain. Some of these men accepted repatriation, but many stayed on in Britain. They found work hard to come by, and the majority appear to have gravitated towards the ports where there vere at least some opportunities in what Little suggests was the only occupation open to them - seafaring. Even in this occupation, their position was extremely precarious. According to Richmond (1961): "The hardships of unemployment and poverty which affected most industries between the two world wars were especially acute in the shipping industry, and the coloured seamen became resigned to the fact that they would be the 'last to be hired and the first to be fired '........ The large majority experienced long spells of unemployment between short spells of work with all the demoralising effects that are commonly associated with prolonged idleness."

With the advent of the Second World War, the position once more changed radically. The greatly increased demand for seamen to man British ships in convoy duties led to a considerable decrease in discrimination against coloured sallors. 
At the same time, as during the first World War, coloured workers came to Britain to obtain employment in the war industries. Thus, not only were the coloured people resident in Great Britain able to find work with relative ease for the first time since the end of the 1914-18 war, but also their numbers were considerably augmented by a fresh wave of coloured immigrants. This time, however, the end of the war did not result in a retraction of the coloured population of Great Britain. The influx of coloured workers during the war merely marked the beginning of the great boom in the immigration of coloured people which was to follow.

\section{The Post-War Growth of the British Coloured Population}

After World War II, there was what appears to have been a period of hiatus in the Immigration of coloured people to Great Britain. Desa1 (1963) states, for example, that Indian and Pakistanl 1mmigration "became numerically slgnificant only after 1952." Similarly, Senior and Manley (1955) claim that Jamaican migration to the United Kingdom "was unimportant before 1954." After this time, however, there was a sudden upsurge in the numbers of both West Indians and Indian and Pakistanl immigrants to Britain which continued, with minor recessions, until the passing of the Immizrat,lori act in 1962.

How did this come about? It can perhaps best be explained in terms of push and pull factors: the push of unemployment and poverty in certain Commonwealth countries and the pull of high rates of employment, or beliefs on the part of Commonwealth citizens concerning high rates of employment, in Britain. The coloured workers who came to Britain during the war, in effect, 
"discovered" Britain and set the later movement afoot. After the war, many stayed in this country. Others returned home, but finding opportunities restricted there, came back again. Finding employment conditions in Britain to be favourable, these people wrote home, often with a certain amount of exaggeration, telling of the opportunities in Britain. Others came, who in turn wrote home, encouraging further immigrants to come, and so on. The whole thing then "snowballed" In much the same way as a chain letter: slowly at first, but with rapidiy gaining momentum once the movement gotunder way. On the basis of a study carried out In Kingston, Jama1ca, In 1954, Maunder (1955) states: "Nearly seventy per cent (of a sample of emigrants to Britain) had friends and relatives awalting them in the U.K. and the cumulative character of the present m1gratory movement is thus demonstrated."

Some idea of the magnitude of this movement can be gained from the Plgures for annual 1mmigration from the West Indies given in Table 1.

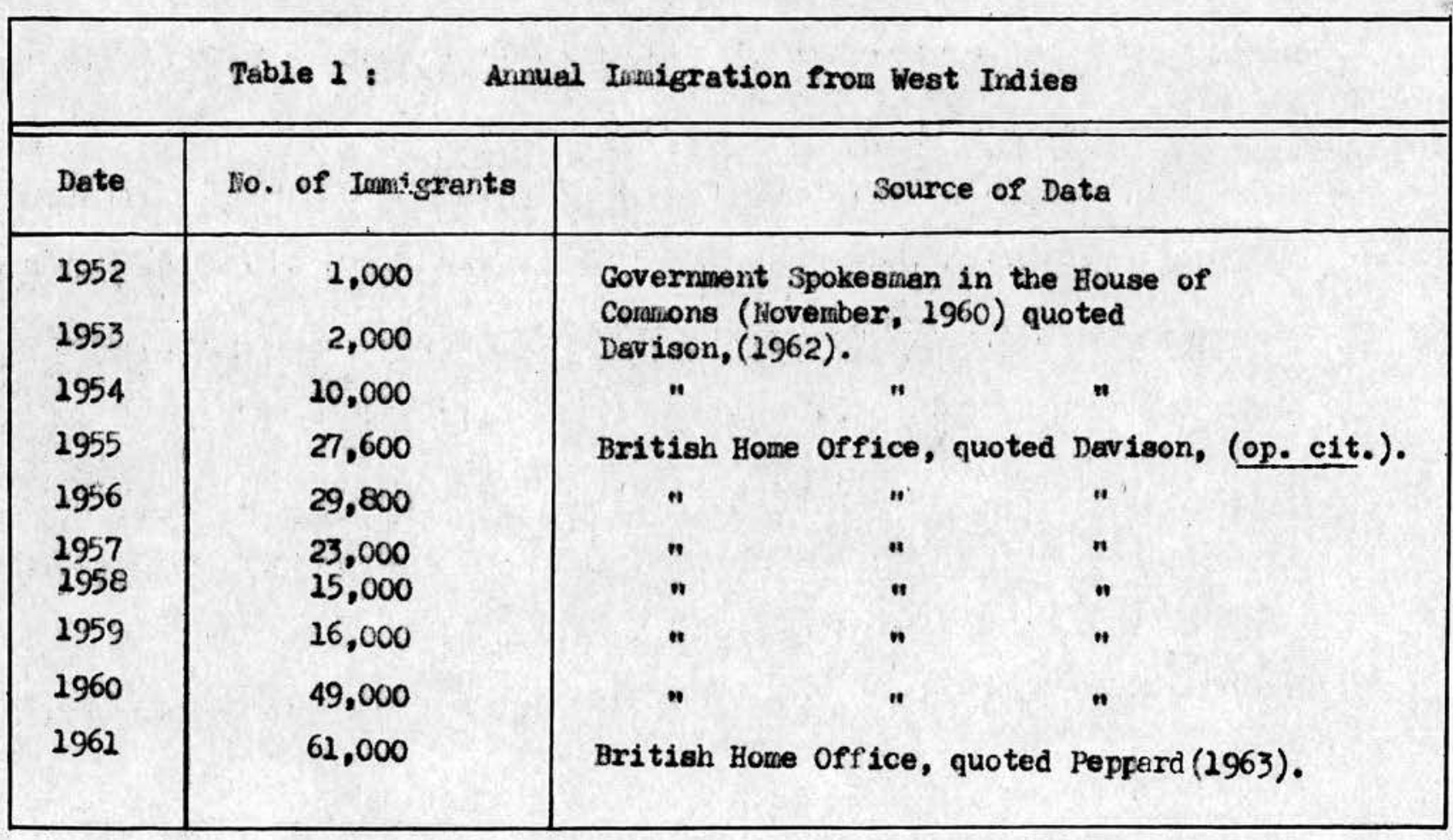


Nevertheless, it is extremely difficult to plot the growth of the British coloured population with any degree of accuracy. Data such as those given in Table 1 are very approximate and estimates differing by as much as 5,000 have been given in the case of the later figures. ${ }^{1}$ Moreover, the exact number of migrants returning home is not known, nor is the original size of the British coloured population. More precise data are now avallable as a result of the 1961 census, but for the earlier figures we shall have to rely upon various estimates which have been made from time to time. It should be emphasised, however, that these estimates are only approximate and that in some cases widely differing totals have been reached.

Census data for 1911, 1921 and 1931 gave the number of West Indians resident in the United K1ngdom as 9,189, 9,054 and 8,595 respectively (Banton, 1955). According to the 1951 census, the number of persons born in the West Indies resident In England and Wales had risen to 15,300 (Wood, 1960). In each case, however, these totals contain an unknown number of people of European stock. As we have shown in Table 1, the number of West Indians in this country grew rapidly in the years following 1951. Three different estimates have been made of the number of West Indians resident in Britain by the end of 1958. Banton (1959) gave the figure as 110,000, the Home Office (quoted Wood, op.c1t.) as 115,000 and the West 
Indian Migrant Services Division as 120,000 . On the basis of the last two estimates, Wood concludes that the true Plgure must have been between 110,000 and 125,000 .

In the following years, the number of West Indians in Britain still continued to rise. An unofficial estimate of the Home Office (quoted Burt, 1960) placed the number at 122,000 in 1959. Richnond (op. cit.) gave the figure of 150,000 for the year 1960. In 1961, Sevlon stated that there were "some 200,000 West Indians ... earning their Iivelihoods in this country." And finally, in 1963, Peppard suggested that there were about 300,000 West Indians in Britain. According to Desai (1963), the current immigration of Indians to the United Kingdom did not begin until the Second World War. Indian seamen formed part of the coloured colonies which grew up in the ports during the inter-war years, but their number was small compared with other coloured immigrants then resident in the country. During the war, however, a number of seamen came ashore in search of jobs in the factories and others were sent by the Government of India to acquire skills and help in the war effort. Some idea of the growth of the Indian population in Britain during this period can be gained from the fact that in 1939, the city of Birmingham had only 100 Indian inhabitants, whereas the figure for 1945 was about 1,000 , the addition consisting mainly of seamen who had moved inland from the ports.

Even during the war and in years imnediately following, however, the number of Indians in Britain was comparatively 
small. In 1949, for example, Kondapi (1949, quoted Desai, op. cit.) wrote that the number of Indians who had been in Britain for a fairly lengthy period was only 5,000. Similarly, Desal suggests that Indian (and Pakistani) 1mmigration did not become numerlcally significant until after 1952, al though he notes that the immigrants coming after 1949 were no longer seamen drifting ashore, but were those whose primary aim was economic gain.

Since 1952, the Indian population has increased considerably. The Indian parliament (quoted Desal, op. c1.t.) claimed in 1957 that there were 17,300 Indians in Britain. In a House of Commons statement (quoted Desa1, op. cit.) it was claimed that the total net inward movement from India during 1958 had been 6,200 and in the first ten months of 1961, 18,300. Finally, Desal himself estimated, from internal sources, that the Indian population of Great Britain in 1963 was 40,000. The immigration of Pakistanis to Great Britain followed much the same pattern as that of the Indians, but estimates of the actual numbers involved have varied conslderably. Kathleen Funter (1963) suggests that the Pakistani population of Great Britain was already 43,000 by 1949: If we accept Desal's statement that Pakistani immigration did not become numerically significant until three years later, it seems likely that this is an over-estimation. On the other hand, it also seems likely that other estimates of the Indian and Pakistani population erred in the opposite direction. Whitaker's Almanac for 1956, for example, gave the total number of Indians and Pakistanis in Great 
Britain as only 10,700 (quoted Desai, op.c1t.). Other estimates include 55,000 in December 1958 (Home office, quoted Wood, op. c1t.), 50,000 in 1959 (Banton, 1959) and 50,000 in 1960 (R1chmond, 1961). With regard to the Home office estimate of 55,000 , Wood stated in 1960 that "Indian and Pakistani officials in this country as well as leaders of the local communities belleve that there are many more of their fellow countrymen than this." Wood himself concluded that "there may well be now between 70,000 and 100,000 Indians and Pak1stan1s in the country." Similarly, in 1961, Waughray stated that responsible Indian and Pakistani leaders believed that there were about 100,000 of their nationals in Britain and not the official 55,000. In the months preceding the Imm1gration Act, Pakistani immigration rose even more steeply. During February 1962, for example, there were 3,400 Pakistani Immigrants compared with only 650 in the previous Febmary. (Home Office statement, quoted The Guardian, March 30th, 1962). By 1963, Kathleen fiunter (op.cit.) estimates, there were 100,000 Pakistanis in Britain, not counting the 40,000 Indians suggested by Desal.

Finally, there have also been estimates of the numbers of other coloured groups in Britain. The Home Office (quoted Wood, op. cit.) gave the figure of 15,000 for December 1958; Banton (1959) suggested that there were 6,000 immigrants from West Africa and 1,500 from Somaliland; Wood (1960) stated that the combined population of West Africans, Somalis and Arabs was probably not more than 25,000; and Waughray (1961) claimed that 
the number of West Africans, East Africans, Arabs, Somalis, Chinese and other far Eastern immigrants amounted to 40,000. As we will see below, however, it seems likely that all these figures are much too low.

Wore recently, It has been possible to estimate the size of the British coloured population on the basis of the 1961 census data and the subsequent arrivals and departures of coloured immigrants under the Comnonwealth Imnigration Act. One such attempt was made by the Institute of Race Relations, (reported The Times, 18th January, 1965) and is presented in a somewhat revised forre in Table 2.

Table 2: The British Coloured Population since the 1961 census

\begin{tabular}{|l|c|c|c|c|}
\hline \hline & West Indians & Indians & Pakistanis & $\begin{array}{l}\text { Others (wainly } \\
\text { West Africans } \\
\text { and Chinese) an } \\
\text { approxination }\end{array}$ \\
\hline $\begin{array}{l}\text { At Census } \\
23 / 4 / 61\end{array}$ & 172,000 & 81,000 & 25,000 & 80,000 \\
$\begin{array}{l}\text { Ind of 1961 } \\
\text { Fnd of 1962 }\end{array}$ & 221,900 & 98,500 & 43,600 & 88,250 \\
$\begin{array}{l}\text { End of } 1963 \\
\begin{array}{l}\text { I964 30th } \\
\text { Noverber }\end{array}\end{array}$ & 264,869 & 138,098 & 68,543 & 102,000 \\
$\begin{array}{l}\text { Fstimate of } \\
\text { children born } \\
\text { here }\end{array}$ & 278,801 & 152,599 & 95,327 & 111,800 \\
$\begin{array}{l}\text { Totals } \\
\text { round figures }\end{array}$ & 430,000 & 165,000 & 123,050 \\
\hline
\end{tabular}

1. The increases from the census date until July 1962 when the Immigration Act came into force are estimates only, and may be too low. 
It will be seen that in some respects the above figures differ considerably from the other estimates presented above. In particular, the figures for the other coloured groups are much higher and the Indian population is given as being larger than that of the Pakistanis. For a variety of reasons, however, it cannot be assumed that the census data provide a complete picture of the size and constitution of the coloured population in Great Britain. Firstly, the census did not obtain information concerning the race of respondents, and details of birthplace alone are insufficient to work this out indirectly because of the large numbers of white people born in predominantly "coloured" Commonwealth countries. In the case of India and Pakistan, this group can tentatively be identified because, unlike the majority of other people born in these countries, they are United Kindom citizens by birth and descent. In Table 2, therefore, these people were omitted in the totals given. As an article in New Society (24th September, 1964) points out, however, this method "is only valid at all for countries which achieved independence some time ago and at best .... Is only rough." Becondly, 1t is highly likely that not all coloured people were counted in the census, especially where they were living in multiple households and under conditions of overcrowding. It is probable, therefore, that the census figures underestimated the true size of the British coloured population. Finally, the census data do not provide information concerning the numbers of coloured children in this country and in the above table these were estimated from other sources. 
As a result of these factors, estimates based on census data, like the other estimates we have presented, may contain certain quite large errors, and in the absence of more accurate data, there is little we can do to resolve the discrepancies involved. At best, the various estimates can be used to provide an indication of the limits within which the true figures are likely to lie. Thus, durirg the years 1962 and 1963 when the field work for the present research was carried out, it seems likely that the West Indian population in Great Britain was between 250,000 and 300,000 and the combined Indian and Pakistani population between 140,000 and 240,000 .

At the time of writing, census data concerning the age and sex ratios of coloured immigrants were not available and we shall therefore have to rely entirely on other sources for this information. In the case of both the West Indian and Aslan groups, it would appear that until recently immigrants have tended to be young adults, both children and the old being greatly under-represented. For example, Wood (1960) found that ninety per cent of Indians and Pakistanis in B1rmingham were between twenty and fifty years of age. Similarly, Davison's (1962) investigations of migrants from Jamaica and Dominica showed that in the region of forty-five per cent were between the ages of fifteen and twenty-five, a further twenty to twenty-five per cent between twenty-five and thirty, and less then ten per cent over forty. As he says: "The economic and social implications of such a lop-sided arrangement need no elaboration." 
During the 'fifties and early 'sixties, it would appear that the sex ratios of Immigrants from the West Indies underwent considerable change. At first the men predominated over the women by a considerable margin. (See Roberts and Mills, 1958). When Davison (op.c1t.) carried out his investigations in 1961, however, 1t was found that both sexes were almost equally represented. Davison states: "The impression gained in the 1961 survey was that the migration had changed its character - the men had gone first, now the women were following them, which suggests that the men concerned were beginning to settle down in Britain with no immediate plans to return to Jamaica."

In the case of the Indians and Pakistanis, the majority of early immigrants were also males, and it seems likely that the proportion was even higher than in the case of the West Indians. Desal suggests that after the middle 'flfties an increasing proportion of Indian immigrants were dependent women and children. With respect to Pakistanis, however, Alavi (1963) states that the trend is now for those who can afford to do so to send for their wives, but the number who are able to come is quite small. In a recent stuây of a multi-racial district in Birmingham, Rex (1965) found a sex ratio of twelve men to one woman amongst the Pakistan1 immigrants.

Finally, it should be noted that with the development of the post-war movement of coloured people to Britain, the pattern of settlement changed radically. In the inter-war period, coloured people were mainly concentrated in various sea-ports. 
The "new" immigrants came for work in industry and therefore tended to settle in the large industrial centres such as London, Birmingham, Manchester, Leeds, Sheffield, Nottingham and so on.

\section{Studies of Race Relations in Britain}

The first major research in the field of race relations in Britain was Iittle's study, published in 1948, of the coloured community in Cardiff. Owing to certain geographical factors peculiar to Cardiff, the setting of this community is of paramount importance. The coloured people in Cardiff, at the time of the study, were mainly confined to the dock area known as Bute Town. Little describes this area as a "peninsula of human habitation ...... almost entirely shit in and cut off from the rest of the world by a compact barrier of docks, water, rails (1.e., rallway lines), fencing, and machinery." In effect, then, we are faced with a comparatively ${ }^{1}$ segregated coloured community of a type now very rarely found in Great Britain.

This segregation may have been partially due to occupational factors - the majority of coloured men were engaged in seafaring in one form or another. Another important factor, however, was the attitude of the rest of the community towards coloured people. According to Little, there was considerable resistance to coloured families obtaining housing accommodation,

1. The restriction of coloured people to the Bute Town district did not result in their complete geographical segregation because there were also many non-coloured residents within this area. However, there was a tendency for the different nationalities to separate along racial lines. 
either as tenants or as lodgers, in the residential quarters of the town because of a fear that their presence would cause a lowering of assessments in the district concerned, and hence a depreciation in the value of the surrounding property. Moreover, the concentration of coloured workers in seafaring occupations appears also to have resulted from resistance on the part of the community as a whole. Ilttle states, for example, that coloured juveniles had great difficulty in obtaining employment: apart from employment at sea, boys were lucky to find work even as errand boys or page boys, or in some other "blind-alley" occupation.

W1thin the Cardiff coloured community, there were three main elements: Arabs, West Africans and West Indians. The two main social groupings, however, consisted of Africans and West Indians on the one hand and Moslems on the other. The Pormer group, Little described as extremely "colour-conscious" and very zealous for the good name of their homeland and of people of African origin. Its members frequently spoke in brotherly terms of the "coloured peoples", but there was a tendency to restrict the term to those of Negroid affinities rather than to apply it to coloured races in general. The interests of the group were to a certain extent political and their nationalistic sentiments found outlet in a social and cultural organisation known as the Sons of Africa.

The majority of the members of the Moslem group were Arabs, mainly from Aden, but there were also fairly substantial numbers of Somalis, Indians, Egyptians and Malays. According to 
Iittle, this segment was essentially religious and social rather than political in its interests, and was bound together by the strong ties of brotherhood inherent in the Islamic creed, despite some sectarlanism in this respect.

Thus the coloured people of Cardiff could not by any means be described as "integrated". Not only were they largely segregated, both socially and geographically from the community as a whole, but even within the Bute Town area the different nationalities tended to remain socially apart. In one sense, this segregation represented a form of accommodation in that it reduced the possibility of conflict between white and coloured people by decreasing the likelihood that social interaction would occur. On the other hand, for the coloured community, the accommodation was attained at the expense of a low standard of Ilving, poor housing conditions, and limited educational and vocational opportunities for juveniles. Iittle concludes:

In the present circumstances, the community may be expected to continue more or less in 1 ts present form, and perhaps even to grow in numbers. The solution to its difficulties lies in greatly increased absorption into the city's ilfe and activities. Thls calls not only for greater racial tolerance and equal opportunities of employment and soclal intercourse, but also for a general "levelling up" of educational and cultural standards.

In some degree, these conditions were in fact fulfilled, as we shall see when we come to examine Collins' later study of the same community.

During the Second World War, 345 West Indian technicians 
and trainees came to work in Britain (mainly in the Merseyside area) under a scheme jointly organised by the Ministry of Labour and the Colonial office. A study of the assimilation and adjustment of this group carried out by Richmond (1954) forms the basis of the second major research into race relations in Great Britain.

According to Richmond, little difficulty was experienced in placing the West Indlan workers in jobs. At the time they arrived in this country (between 1941 and 1945) labour was in extremely short supply and employers could not afford to be choosey about the colour of the workers they hired. One or two firms were somewhat dublous at first, but even these later relented when labour became st1ll more scarce.

Relations between the West Indians and management varied considerably amongst the different firms in which they were employed. Richmond concludes, however, that they appear to have been best where the number of West Indians was not large, where the skill of the men was at least comparable with that of the average English worker, and where there was no minority of badly adjusted West Indians to spoil the reputation of their fellows. Adjustment was found to be significantly related (at the .01 level) to the occupational level of the technicians and trainees.

W1 th regard to relations between West Indian and British workers, Richmond states that although there was some variation, they tended to follow a similar pattern in most firms. The Brit1sh workers' first reaction was one of surprise and shock to find a group of coloured men doing skilled work. This was 
followed by a stage when the West Indians tended to be treated as an out-group and something of a scapegoat for the problems and difficulties experienced in the factory. Pinally, the West Indians became accepted as part of the natural order of things and whilst not always completely incorporated into the ilfe of the factory, were at least tolerated and respected individually according to their merits. On the part of some British workers, Richmond suggests, att1tudes towards West Indians appear to have been distinctly ambivalent. There was genuine admiration for the skill, workmanship and other abilities shown by some of the West Indians and yet a certain reluctance to give them full credit due to the difficulty of completely throwing off previous bellefs concerning the inferiority of coloured people.

A more difficult problem than employment proved to be that of accommodation. When they first arrived between 150 and 200 of the West Indians were housed in hostels, but this scheme was not altogether successful and many set about finding their own accommodation. They found lodgings, especially the better type, very hard to come by. When they did eventually find someone who was willing to take them, the accommodation offered was not infrequently dirty and overcrowded, often with several beds in the same room. In spite of this, high prices were charged, but the coloured men, finding it impossible to go elsewhere were forced to take what they could get.

With regard to personal relationships, Richmond reports that att1tudes towards the West Indians varled a great deal from 
person to person and ranged from complete tolerance and acceptance to complete rejection. Despite this wide range of attitudes, however, stereotyped views about Negroes still persisted and were widely accepted. Sometimes, for example, surprise was expressed at the fact that West Indians could speak Mnglish or had had any experience with machines before coming to Britain. Stereotypes concerning the Negroes alleged promisculty and abnormally high sexual potency were perhaps those which had most serious repercussions. Richmond states that sexual rivalry amongst nelghbours and close acquaintances of the West Indians appeared to be a constant source of friction. Men who were accepted in the ordinary course of events were subjected to serious insults if seen in the company of a white girl, and the girl herself was often stigmatised amongst all "respectable" people.

In English society, Richmond suggests, the position of the Negro can be summed up as that of the "marginal man". He can, if he wishes, achleve a good adjustment in his personal life by withdrawing into the coloured community and seeking all outlet for his soclal impulses amongst other coloured people. In practice, Richmond claims, this only happens in rare cases and usually represents an accommodation pattern that is a result of an inability to face the anxieties created by any attempt to gain acceptance in the white comrnunity. The majority of West Indians very much desire to be fully accepted as British subjects, with all the privileges that such status implies. However, the extent to which such acceptance can be 
obtained is often vague and unpredictable in Britain and the resulting ambiguity is a source of anxiety to the Negro, which in turn produces inevitable personal maladjustment.

The behaviour of the West Indian Negro in Liverpool, Richmond concluded can best be understood in terms of his attempt to escape from the isclation that segregation and prejudice create, and to participate more actively in the social life of the people about him. Yet in his attempts to break down the barriers, the more frustration he experiences and the more anxiety about his status and security he feels. Frustration and anxiety in their turn create a great deal of conscious or unconsclous aggression which sometimes earns the Negro a reputation for undue truculence.

We turn next to Banton's (1955) study of the coloured community in Stepney. Although the proportion of coloured people in Stepney as a whole was not high - about one per cent In 1951 - they tended to be concentrated in one part of the borough. As a result, this area had gained the reputation of being a "coloured quarter". Bven here, however, coloured people never comprised as much as half the population of any one street; their houses were situated amongst those of Jewish and Finglish residents and only rarely did they occupy as many as four successive houses. Thus the area was not a coloured ghetto, Banton concludes, but rather "a depressed working-class neighbourhood sheltering residents of many races and nationalities."

Amongst the coloured people in Stepney there were two 
main groups with somewhat overlapping areas of settlement but differing modes of adjustment to life in Britain. These were, on the one hand, the West Africans, West Indians and Somalis, and on the other, the Sikhs and Pakistanis. It is with the Iife and adjustment of the "Afro-West Indian" group that Banton's study is mainly concernec, but some detalls of the Sikh and Pakistani community are also given for comparative purposes. Coloured immigrants in Stepney, Banton states, tended to Iive in the poorest housing property close to factories, warehouses and rallways. This he attributes partly to the fact that few immigrants qualified for council housing, partly to their willingness to tolerate inferior living conditions and inability to pay high rents, and partly to colour discrimination on the part of landlords. Because Fnglish landlords and landladles were generally reluctant to take coloured lodgers, the immigrants were often forced to accept poor accommodation at relatively high prices from the few people who were prepared to let rooms to them. The high prices in turn led many immigrants to sub-let rooms to their fellows. The poor housing conditions, Banton states, were to some extent responsible for the somewhat unstable life led by many of the immigrants and the high rate of residential turnover.

As a result of the depressed conditions and low social standing of the coloured quarter, the more ambitious and able immigrants tended to move out of Stepney once they had become acclimatised to life in this country. On the other hand, many of the Immigrants living in the better residential districts 
came back to Stepney in the evenings and at week-ends to meet their friends. "Especially at week-ends, coloured men come there from other parts of London for African-style food, for girls, and for relaxation in a neighbourhood where their different appearance does not make them objects of particular attention. There is a defintte feeling among them - especially among some of the less sophisticated immigrants - that Stepney is the coloured man's district, that they have occupied it and made it their own, and they behave there with much greater freedom than they do elsewhere." Thus Banton concludes that the coloured quarter serves a double function for the Negro Immigrants: firstly, it is a transition area where many settle before moving on to other areas, and secondly, it is a soclal centre for far more Negroes than those who actually live there.

Unlike in Cardiff at the time of Little's study, only a fraction of the Stepney coloured communtty were employed in the shipping industry. The majority worked permanently ashore, mainly in rough labouring jobs. In the post-war period the demand for labour had at most times been greater than the supply, and Banton suggests that there were sufficient firms willing to accept coloured workers for their absorption into industry to have been nearly complete had they been found as satisfactory as local labour. This was not the case, hovever, and many firms, having given coloured workers a trial, refused to engage any more, thus considerably limiting the number of jobs avallable to them. The major difficulties arose from 
their unfamiliarity with the kind of work which was required of them: they were said to be inefficlent and indolent and hand lcapped in some cases (especially the Somal1s) by Inability to read and write Inglish with any Pluency. Many were said to develop a "chip on the shoulder" attitude and to ask for their cards on the slightest provocation. In addition, cases occurred where other workers objected to the employment of coloured men, and also where a whole batch of coloured workers were dismissed because of the faults of a few.

To the individual Immigrant, Banton suggests, the task of getting a job and keeping it was a problem of adjusting his expectations to the opportunities open to $\mathrm{him}$, and becoming accustomed to what was required of him. In the main, jobs offered West Indians and West Africans did not come up to their level of expectation and as a result severe disappointment was experienced. They tended to change jobs frequently, searching for something better and many were unwilling to do work which to them appeared degrading. Many also developed the view that the coloured man did not get his deserts unless he threw his welght around and made trouble when he did not get what was due to him. Banton contrasts this with the attitude of Pakistanl immigrants who avoided conflict, made few demands, and were willing to put up with conditions which the African would reject.

Banton relates the contrasting form of behaviour in the industrial context to wider differences in the general mode of adjustment of these two groups to l1fe in Britain. The Pakistanis 
and Sikhs, he suggests, are examples of non-assimilating or accommodating groups. They wish to preserve their own culture and adopt as little of the customs of the receiving country as possible. The Afro-West Indian group, on the other hand, are an adapting group. They largely accept the norms and values of the host society and wish to become assimilated. They were prevented from doing so, however, by the withholding of acceptance and social equality on the part of the British public, especially in spheres which are of particular importance to the coloured population, such as employment, housing and relations with English women.

This in turn profoundly affected the behaviour and attitudes of the Afro-West Indian group. In many cases, the frustration of their hopes and the denial of what they felt was due to them as British citizens led to the rejection of British values and the development of "anti-social" attitudes, thus giving rise to further barriers to assimilation. Frequently, there was extreme suspicion of the actions of any Englishman, and abuse and truculence, supported by the belief that the coloured man must throw his welght around in order to get his due, were common. On the other hand, others conformed, and in some cases over-conformed, to the standards of the dominant group in an attempt to gain prestige and self-esteem in socially approved ways. Nevertheless, one thing appears clear - at the time of Banton's study, nelther group were socially integrated into British society. The fact that even the better adjusted immigrants needed to return to Stepney in 
order to relax amongst their own people demonstrates that withdrawal into the coloured community for the fulfillment of social needs is not as rare an occurrence as Richmond would suggest.

The question of the different modes of adjustment made by Negro and Asian immigrants to their life in Britain is further examined in Collins' (1957) Coloured Minorities in Britain. Collins' study is mainly concerned with two coloured communities, one Negro (African and West Indian) and the other Moslem (Arab, Somali and Pakistani), situated in adjacent ports on Tyneside. There were some basic similarities between the two communities: in both cases 1 ) the main occupation was seafaring, 2) the original settlement had been depressed areas alongside the docks, and 3) there had been some intermarriage with native British women. With regard to the subsequent area of settlement and their orientation towards the culture of the host soclety, however, there were wide differences.

In the Negro community there were three main housing areas, Edward Square, Old Dockland and the Counc1l Estate. Edward Square was the "nucleus" of the community in the sense that it was the point of entry and a centre from which dispersal took place. It was situated in the least desirable section of town, the bulldings were in need of repair, and there was some overcrowding. Here the coloured population consisted mainly of newly arrived immigrants, the unemployed and those least adjusted to British society. In Old Dockland, the houses were in better condition, there was no overcrowding, and the people 
living there had higher prestige and esteem. There was continual migration from Edward Square to this area. Finally, the Council Estate contained the families best adjusted to British life and who occupled the highest social and economic position amongst the coloured population. The residents here were mainly old Timers (1.e., pre-war Immigrants) who retained their status quo by observing those norms of behaviour which would bring esteem to the coloured population and by dissoclating themselves from the aggressive behaviour of the New Comers, most of whom lived in Edward Square.

The Moslem Community in the neighbouring port, on the other hand, was largely confined to a single area situated, like Edward Square, in the least desirable part of the town. This concentration of Mcslem Immigrants resulted partly from action on the part of the Corporation - Moslem applicants to the Housing Department could only rent councll houses in their own areas of settlement - but another factor Collins suggests was the voluntary acquiescence of the Moslems to the Corporation's policy. "The immigrants' whole manner of life," he states, "suggests that they have a preference to retain and strengthen the social relationsh1p with members of their own group rather than endeavouring to be absorbed into the life of white society."

This separatist orientation towards the culture of the host soclety was most noticeable in the sphere of the family. In the Moslem community, the husbands imposed the values and norms of their own culture in the home: wives tended to adopt these values and norms and the children were brought up to be 
Moslems. In the Negro community, on the other hand, the father did not attempt to communicate to his children elements of his native culture. Instead, he encouraged them to acquire the British norms and values in order that they might gain as many concessions as possible from the host society.

Similar differences in orientation were found by Collins in Cardiff when he re-visited the Negro and Moslem communities already studied by little in the early 'forties.

Anglo-coloured chilaren of Negro descent had taken advantage of the much wider occupational opportunities avallable to then in the post-war years and were beginning to rise above the low social position of the Negro community. However, no similar trend was observed amongst Anglo-Moslem children. This Collins attributes to the attitude of the parents, especially the father, who tended to be so obsessed with the desire that his children should follow in his cultural ways that considerations of their formal educational progress was not given the urgency and importance customary amongst Negroes.

Thus it appears that in each community there was a tendency towards self-segregation on the part of the Moslems and towards integration on the part of the Negroes. Collins suggests, however, that both tendencies were present in each case. During the process of immigrant settlement, he claims, two social forces moving in opposite directions can be observed. First, on arrival, there is a tendency to keep within, and to associate closely with members of, the immigrant community. This is a necessary stage of adjustment since the immigrants, 
new to the ways of the host society, find amongst people of their own culture common grounds for close social relationships. However, this centripetal force may be, and in Britain is, augmented by social pressures from the host society which tend to compel the immigrants towards residential separation. and social exclusiveness. On the other hand, as immigrants begin to learn the mores and values of the host society, there is a counter-tendency for them to become less dependent on their own groups, to make contacts with British people with increasing freedom and to share in greater or lesser degree the life and privileges of British society. This is a process of social adjustment, Collins clains, and one of the visible signs which usually follows is the tendency for the better adjusted to disperse among whi $\iota \in s .1$

The different patterns of adjustment achieved by Moslem and Negro immigrants result from the fact that the opposing centripetal and centrifugal forces do not operate with the same strength on the different inmigrant groups. The Moslem immigrants preserve their traditional institutions and are orientated towards their countries of origin, and therefore tend to maintain their social cohesion and to be more resistant to assimilation. On the other hand, the West Indians, because

1. "Better adjusted" is perhaps an unfortunate term as it implies that the values and norms of the host society are the only ones which determine the level of adjustment. It is quite feasible, however, that an Asian inmigrant who was extremely well adjusted in terms of his own ethnic group would for this very reason psefer to stay within it. I would therefore prefer the term "more acculturated" in this context. 
of their early acqualntanceship with British ways of life, associate more freely and more quickly with members of British society. The Africans fall between these two extremes: they tend to maintain their tribal groupings, but in their new social environment these tend to lose their intrinsic traditional functions and to become orientated towards British society. Nevertheless, it is apparent from Collins' description of the various communities, that both forces were operating, at least to some degree, with respect to both groups: many West Indians remained within the bounds of the immigrant community and some Moslems moved outside their own social grouping.

The four studies we have so far examined represent, in effect, the war and post-war background to large-scale immigration of coloured peoples to Britain during the 'fifties. As we have already noted, this immigration movement was directed towards the centres of industry rather than the ports. The coloured communities in Cardiff, Liverpool, Stepney and on Tyneside are, therefore, to some extent atypical of those which developed later in the inland cities. W1th respect to Stepney, for example, Banton states that because the more able and ambitious newcomers soon left the district, those left behind were not typical of the immigrant population as a whole. Moreover, the attitude of the native British population towards the immigrant who settles away from the ports is likely to be different. Banton states: "In Stepney, and in many other parts of the country the general public have tended to think of the coloured men as being seamen, who, though they may work ashore, are never permanent residents. 
In this way people have been able to 'place' the coloured man in the social structure even if they did not always fit very well into this category." In the inland cities this type of "placing" of the coloured man becomes far more difficult. He becomes, in effect, a different kind of stranger; one who, as Simmel (1950) puts it, comes to-day and stays to-norrow. Nevertheless, the problems faced by these immigrants are much the same as those encountered in the ports; difficulties in finding somewhere to live, difficulties in finding somewhere to work, and lack of social acceptance on the pirt of the host society. In order to avoid undue repetition, therefore, we shall present a general outline of each field rather than examine in turn the later studies of race relations in Britain. We shall here be concerned mainly with housing and social relationships, the question of employment being examined more fully in the next chapter.

Senior and ianley (1955) state that the coloured immigrant faces three kinds of problems: (1) those already faced by a large number of the Brit1sh working class; (2) those encountered by any "stranger" who entera an area where he does not know how to cope with problems of every day life as well as the local citizen does; and (3) those arising from his colour. Housing provides a very good illustration of this point. Senior and Manley stated in 1955, and the position does not seem to have changed much since then, that: "The situation......varies in intensity but in all industrial cities housing is a major problem for the working class, whether local or recent arrivals." 
However, the stranger, whether from the West Indies, India, Pakistan, or merely another part of Britain, is at a disadvantage compared with the local resident because he has not had the same opportunities for putting his name down on walting lists. In addition, the coloured stranger has the further disadvantage of having to face the problem of racial discrimination.

It should be noted immediately that this discrimination very rarely occurs in Council housing. In nearly every town with a significant number of coloured residents there are some coloured tenants in Counc1l property. These are the familles who have lived long enough in the area to fulfil whatever residential qualifications are laid down by the local council. Occasionally the wife is a local white girl, but more often the family had been living in slum property which had been demolished. 1 For the majority of immigrants, however, the chances of obtaining a counc1l house are quite remote, simply because there is a long queue and they are at the end of 1t. The 1mmigrant must therefore find alternative accommodation. The usual way of doing this would be to find lodgings and this is where discrimination is encountered.

Two analyses have been made of the reaction of landladies in London to coloured students. In these it was found that "approximately $70 \%$ of landladies were unwilling to accept coloured students and as far as very dark Africans or West Indlans were concerned the flgure was nearer 85\%." (Richmond, 1961). There are some indications that lower class coloured 
people face even more resistance. Another investigation, (quoted, Davison 1961) has shown that although $94 \%$ of 'midale class' students felt that they were experiencing discrimination in their search for lodgings, only $63 \%$ of 'upper class' coloured students felt that they had.

Faced with this kind of discrimination, working class coloured people have tended to move into the more delapidated areas of the towns in which they find themselves. Here accommodation is easier to come by; white householders cannot afford to be too choosey about the colour and social status of the tenants, and in some cases may even welcome coloured tenants because they can take in a greater number of people at higher rents. Often coloured people themselves buy houses in these areas and then sub-let them to other coloured people. 1 Once a few 1mmigrants have become established, others join them and a "snowballing" process begins. Immigrants just arrived in Britain join friends and relatives already living there who can help them to settle down in the country. By this time, white people are beginning to move out where possible, thus freeing more accommodation for immigrants, and the area is well on the way to becoming a "coloured quarter."

Donald Wood describes a typical area of coloured settlement

1. Shella Patterson (1963) states, with respect to the Brixton coloured community, that the two terms "house-owner" and "landlord" are really synonymous. The idea of making a "home" is not often encountered as yet, and property is rarely regarded as anything more than a short-term source of income. 
as follows:

There is a noticeable unformity in their housing conditions. The majority live in poor workingclass areas where the houses, if not actually due for clearance, are délapidated and unsatisfactory according to the standards of to-day. Typical houses for coloured single men and families are large Victorian terrace houses that in their palmy days amply accommodated a middle-class family and its servants. As other parts of the town grew fashionable, these families moved and the terrace houses declined in social prestige. Speculating landlords bought them, let them and sub-let them. They have often grown delapidated through rough use and lack of attention........ Overcrowaing according to statutory definitions and according to local white norms is common throughout the country. Rooms are turned into dormitories; families 11 ve and sleep in a single room and share lavatories and kitchens with others in a similar plight.

Wood notes, however, that these areas are not, with very few exceptions, ghetto-like coloured quarters like those in some American cities, but are instead concentrations of coloured people in particular areas where white people also live. Shella Patterson's (1963) study of the Brixton coloured community provides a good example of such a concentration of coloured people, and the conclusions she draws have considerable relevance to the question of coloured quarters in general. In Brixton, Mrs. Patterson states, the West Indians have evolved their own solution to the problem of living space by buying up 
deteriorating property, much of which had ceased to seem a sound investment proposition to local investors, and by filling it with fifteen to twenty-five people instead of the two or three English families who formerly lived there. Thus the arrival of 10,000 newcomers did not aggravate the housing shortage as much as might have been expected, nor as much as many of the local people st1ll believe.

In the short run, she suggests, in spite of the overcrowding and physlcal discomfort, the concentration of West Indians in Brixton eases the immediate process of adjustment and adaptation for the newcomers. "It provides something of an oasis where they can relax among their own people after the strain of coping with everyday life in an unfamiliar and highly industrialised urban environment. The process of accommodation is also helped by the presence of an increasing number of West Indian women and family units." Mrs. Patterson believes, however, that such an area of coloured settlement may consolidate into a ghetto ${ }^{1}$ and draws attention to the dangers inherent in this process. "In all minority group settlement," she states, "such a ghetto tends to perpetuate minority group values and traits, to limit social and cultural contacts between newcomers and local people, to reinforce local views on the alienness of newcomers, and so retard ultimate integration or assimilation." Moreover, she notes, the coloured ghetto is likely to be self perpetuating because of its high visibility. Long after the Polish, Italian and 
Jewish ghettos have blurred and merged into the rest of the c1ty, the coloured ghetto can remain, not as an area where temporary migrants or people of a different sub-eulture prefer to live, but as a depressed area regarded by the majority society as suitable for people who, however much they may have come to share the same living patterns and cultural values, are still visibly different and socially unacceptable to that society.

At present, it is too early to come to any firm conclusion with regard to the possible future emergence of such ghettos. Mrs. Patterson states that the further evolution of the South London coloured community will depend very much upon the number of Immigrants who decide to stay in Britain and accommodate themselves to the local life, and on the number who actually carry out their present intention of returning home within a few years. If a large number decide to stay, she suggests, one may expect a gradual movement into single-family houses and flats outside the coloured quarters by the most successful and established settlers, which might to some extent offset the similar movement of white families away from the main coloured concentrations. Even at the time of Mrs. Patterson's study, those West Indian Immigrants who had become settled and financially secure usually left the overcrowded central areas of coloured settlement after a year or so and moved to streets with a better social standing and a lower concentration of coloured residents within a two or three mile radius of the centre. She suggests, however, that the main West Indian 
concentrations in Brixton will almost certainly renain as they are until some officlal housing progreme disposes of them.

It nust be renembered, however, that by no means all coloured immigrants are West Indians and Hrs. Patterson's conclusions may not apply with equel force to other immigrant groupings. According to Alavi, (1963) Pakistoni settlements, like those of the Fest Indians, tend to be concentrated in particular strsets or localities. This he attributes partly to the fact that they can only obtain accomolation in the slum areas, but also to "a tendency anongst Pakistanis to keep to areas where other Pakistanis live and not to go far out where they may be alone and lonely." Desai, on the other hand, found that whilst there was some tendency for clusters of Indian houses to occur, the majority were fairly well dispersed, albeit within the poorer districts of the town in which they lived. Part of the explanation for this may lie in the different migration pattern of the two sroups.

Alavi alstinguishes between three main stages in Pakistani immigration. Firstly, there was a small number of immigrants, malnly ex-sallors, who came before the last war. In the second stage, which lasted until the mialle flftios, the imnigrants. were mainly friends and relatives of people who had already settled here. Generally, they came to reside with relatives and this phase gave $r$ ise to mary extended housenolds. The third stage arose through the activities of the "Agent" who rounded up people from the villages by painting rosy pictures of life in Britain. The new phase altered the pattern of 
settlement in Britain. Having no roots whatsoever, the later immigrants have tended to live in dormitories with others similarly placed. The main factor which influenced their behaviour, Alavi suggest, was a sense of helplessness in an alien atmosphere. They very quickly came to depend upon any of their fellows who are more knowledgeable and willing to help. The majority of Pakistanis, he claims, live in such "bachelor" households.

From Desal's description of the Indian groupings, on the other hand, it would appear that the family organisation is still strong. Moreover, with the increasing arrival of wives and chlldren, the pattern of living is changing. Whilst there used to be a tendency for iraternal males to share sleeping accommodation, it is now the nuclear fam1ly which occupies a bedroom. It seems likely that this is one of the main factors contributing to the relative dispersal of the Indian immigrants. The greater privacy required by the wives makes dormitory living impossible and the cohesive family organisation facilitates the buying of new property on a co-operative basis. Nevertheless, it should be noted that this dispersal largely takes place only within certain areas, and that these are often the areas in which Pakistanis and West Indians also tend to Iive. It cannot, therefore, be taken as any indication of their acceptance by or integration into the host society.

The question of social acceptance is of course intimately related with that of housing ard the settlement pattern of coloured 1mmigrants. The lack of social acceptance on the part 
of the host community is one of the main factors which leads coloured people to settle in particular areas; firstly because the difficulty in obtaining accommodation in the better parts of the towns in which they settle means that they tend to become concentrated in the poorer districts, and secondly, because the immigrants are forced to rely almost exclusively upon each other for the fulfiliment of their social needs. 1 Moreover, the concentration of coloured people into particular areas, by increasing their visibillty as a group, is likely to further increase their lack of social acceptance and a vicious circle is thus brought into existence making it even more difficult for them to leave the coloured areas.

In Collins' study, those immigrants who had managed to get away from the areas of high coloured population and become dispersed amongst the members of the host soclety had thereby gained a relatively high degree of social acceptance. ${ }^{2}$ On the other hand, there was considerable social distance between the coloured people in the areas of coloured concentration and the

1. It is possible to over-estimate these factors. As Collins (1957) points out, there is a natural tendency for the new immigrant to form social groupings with his fellow immigrants, irrespective of the degree of soclal acceptance, and the purchase of accommodation in the poorer districts can partly be explained in terms of lack of funds. Nevertheless, social acceptance is an important factor and one which is $11 \mathrm{kely}$ to become more important the longer the immigrant remains in the country.

2. Here again, other factors appear to be involved. The immigrants who became dispersed also tended to be those who had become more "adjusted" to British soclety, However, it is unlikely that even they wouid have achieved the same degree of social acceptance by British people had they remained within the coloured community. 
white residents still living in these areas, not only in the community studies by Collins but also in those studied by Iittle and Banton. That this is not merely a feature of coloured communities in ports and dockland areas is shown by Sheila Patterson's recent study of Brixton.

Mrs. Patterson suggests that when a large number of coloured people arrive in an area one of the first reactions is surprise, or what she calls "colour shock". "People in the United Kingdom knew that the majority of inhabitants of the Commonwealth have coloured skins; some had encountered them on their own ground; many were used to the idea that there were old-establ1shed coloured communities tucked away in dock and port areas in Britain 1tself. But to be confronted with coloured people in the centre of large industrial cities - this was something that seemed at first strange and even out of place to most people here." By the time Mrs. Patterson's study was carried out, local people had got used to seeing a large number of coloured people in the streets and in public places. However, the fact that people were accustomed to their presence did not mean that they had achieved closer acceptance. As one of her respondents put it, "There are so many darkies about now that Brixtonians take them for granted. While the majority cannot be sald to accept them fully, they are resigned to their presence." In the early years of any migration movement, Mrs. Patterson states, soclal adaptation and acceptance are minimal on both sides. "The recelving society may be fairly willing to open factory gates, church doors, pub doors and so on. But few 
of its adult members are willing to open to strangers that ultimate door, the door to their homes." Social relationships between migrants and the local population, she claims, were still mainly restricted to casual contacts in the streets, shops, buses and public houses. Only a handful of the settled Brixtonians who were interviewed had ever visited a coloured home socially or invited a coloured visitor to their own home.

Even outside the home, close social relations were minimal. Contacts between migrants and local people in cefes and restaurants were relatively few because the West Indians preferred where possible to eat their regional food at home; in the pubs, white and coloured men rarely drank together; and for a variety of reasons little social integration had taken place within the churches. ${ }^{1}$ As far as work relations were concerned, there were indications that an initial hostility and rejection had been to some extent modified and a certain degree of accommodation attained on both sides. Such accommodation was still limited, however, and tended to be confined to the work situation with very little or no carry over of these relationships to the neighbourhood or to informal social life. ${ }^{2}$

1. For further details on coloured immigrants and the churches see Patterson (op. clt.) pp. 252-262 and C.S. Hill's West Indian Migrants and the London Churches.

2. The latter conclusion was supported by the findings of a poll conducted by the British Institute of Public Opinion. On the basis of this survey, Senior (1956) states: "The experience of West Indians ..... indicates that relations at work are much better than off-the-job perscnal contacts. Whereas $50 \%$ of the outside relationships were felt to be 'all right' or better, $78 \%$ of the workshop contacts were so characterised. There is a four-to-one differential in the 'very well as a frlend' category; $10 \%$ outside work to $40 \%$ at work." 
This, then, was the position in Brixton at the time of Mrs. Patterson's study; some degree of accommodation had been achieved in the flelds of employment and housing, but coloured people were still not accepted in the sphere of social relationships. Moreover, the fact that Judith Henderson (1960) reached remarkably similar conclusions in her summary of the sociological aspects of race relations in Britain would suggest that these findings can be applied not only to the Brixton community, but also, with reasonable accuracy to the situation in the country as a whole. As both writers point out, however, it would be a mistake to interpret these findings in terms of colour alone. Sheila Patterson notes that the unwillingness of Brixtonians to accept coloured people "is reinforced by the reserve, lack of sociability and fragmentation that characterise informal social life in large Inglish cities." Similarly, Judith Henderson states: "Keeping to oneself is a characteristic of the Britlsh townsman, and even where long standing propinquity has broken down the barriers within the street, they are more than likely to be re-erected around the newcomer, particularly a coloured man." In other words, a considerable degpee of social distance is to be expected even between members of the host society in a community situation, and the relative social isolation of the coloured person is an exaggerated form of an already existing process. Nevertheless, the coloured man's reaction to h1s lack of social acceptance will depend not so much on the objective situation but upon how he percelved it, and being unused to the norms of the recelving society, his 
colour may seem to be the only factor which is involved. This brings us ance more to the question of the migrants' expectations and the different orientations towards the host society of the West Indian and Asian groups.

The tendency for West Indians to expect full acceptance into British society was noted in the studies of Richmond and Banton which we have already examined. The same point was made by Ruth Landes (1952) when she said that the coloured immigrant "guides himself in terms of the logic of complete acceptance, whereas Britons act in terms of a much more limited acceptance," and reiterated more recently by Burt (1960) who states:

It is fair to say, I believe, that the British have an unreasonable aversion to foreigners within their community, and that the West Indian arrived in Britain with unreasonable expectations of the warmth with which he would be received. The "collision" of these attitudes can be seen in the numerous petty complaints that Britons may be heard to give about their West Indian neighbours and that the West Indians may be heard to return. According to Burt, $58 \%$ of a sample of 320 West Indian workers interviewed in 1955 had received no information concerning conditions in this country before they migrated from the West Indles. Furthermore, over half of the remaining $42 \%$ had received no unfavourable information. Until the summer of 1958, he goes on, the information bulletins sent to the Islands by the Commission for the West Indies did not mention 
the fact of colour discrimination existing in any form in Great Britain and the individual migrant was ashamed to write home of personal frustration in the land where - as everyone knew life was perfect.

Following the publicity given to the Notting Hill and Nottingham riots, it would be possible to argue that the migrants' expectations with regard to British society are no longer so unreallstically high and that the contrast in expectations between immigrant and host is, therefore, no longer an important factor in intergroup relations. However, this would be to confuse two meanings of the word to expect: It is unlikely that the West Indians still expect to obtain full acceptance in the sense that they think that it will be easily achieved. On the other hand, this does not mean that they do not think that it should be easy to obtain, and in this sense their expectations are still high and are still a possible source of friction.

In the case of the Asian immigrants, however, such considerations do not apply. They do not expect social acceptance and what is more important, do not appear to desire 1t. Desal states:

The relations between the Indians and the non-Indian neighbours are to a great extent negative. This is partly due to the pattern of Fnglioh behaviour, of which the 1mmigrants are totally 1gnorant. But it is also due to the fact that the immigrants themselves desire exclusion ...... The male immigrants sometimes develop a friendsh1p with neighbours at the local public house. But it does not extend outside the pub. 
The children of the immigrants also enter into relationships with non-Indian children in school or in the street. But this also does not extend to the parents. The immigrants cannot easily communicate in Inglish. Both sides lack common cultural interests and do not desire interaction. The Indian immigrants recognise as nelghbours only those who belong to their own linguistic reglonal group, and find this sufficient. They 1gnore the rest.

Sim1larly, Alav1 states w1th respect to Pakistanl 1mmigrants:

Pakistanis keep to themselves and tend to look upon this as a virtue. This way, they hope to minimise the opportunities for conflicts. But they all feel very insecure and have a great deal of anxiety about the outbreak of racial trouble. This fear tends to drive them inwards into their own community rather than to induce them to consclously seek to establish relationships with locals.

Nevertheless, this pattern of voluntary segregation is not entirely successful in avolding conflict. According to Desai, the 'avoidance' relationship between Indians and nonIndians makes it difficult to pick quarrels readily, but once a quarrel starts it is likely to be more violent than if it were within the Indian group. In the latter case, there are conventions for the settlement of the conflict without violence, but these are not available in a quarrel with outsiders. Furthermore, Alavi suggests that avoidance may only intensify susplcions on both sides and thereby perhaps even cause rather than prevent conflict. 
Thus, in spite of their differing orientations, the West Indian and Asian groupings have, for the moment, made a remarkably similar adjustment to their life in Britain. Both tend to be concentrated in certain areas; both, although for different reasons, are rellant upon their fellows for the fulfillment of their social needs; and both, again for different reasons, may find themselves in conflict with members of the host society. In the future however, assuming that both groups remain in Britain, these patterns of adjustment may develop along divergent Iines. At the moment, the West Indians - speaking English as their native language and largely conversant with and accepting British norms and values - are capable of achleving a high degree of social integration. They are prevented from doing so mainly by the lack of acceptance on the part of the host society. Any future increase in acceptance is therefore likely to lead to greater integration. In the case of the Asians, however, their voluntary segregation from the host community has aided their accommodation in the short run but at the same time decreased their opportunities to acquire British norms and values and to learn the Bnglish language. Thus an increase in social acceptance is less likely to occur, and even if it did they would be less likely to take advantage of it. For this reason, the social integration of Asian immigrants, if it occurs at all, will be an extremely long term process.

4. Theories of Race Relations in Britain

Following the general discussion of race relations theory 
in Chapter One, we now turn to a more detailed examination of the theories which have been developed within the context of the racial situation in Great Britain. In particular we shall be concerned with those of Little, Carey, Richmond and Banton, beginning with the "colour/class-consclousness" theory put forward by Little (1948, 1956).

Ilttle suggests that skin colour has a definite significance for many English people - a darker skin making a person socially less acceptable. This means that there is a tendency for Africans and darker West Indians to be avoided not merely because they are racially different, but because of the likel1hood of social stigma from such an association. "In other words," he states (1956), "colour prejudice is to some extent linked with class prejudice, and this means the frequent exclusion of even well educated persons of colour from British middle-class homes. Though many of the individuals concerned may lack personal prefudice, they feel that their social reputation may be jeopardised if they are known to have coloured friends or acquaintances." To introduce a Negro into their social circle, little concludes, would cause embarrassment because it would lower their prestige in the same way as bringing the milkman or the grocer's boy into the house. Supporting evidence for this theory is to be found in later studies. Carey (1956), states, for example, that little's "colour/class-consclousness" theory was strongly supported by the evidence of his study of Colonial students. Landladies often objected to taking coloured students because they saw in 
this a confession of "having come down in the world." Even those who were themselves favourably disposed towards coloured students sometimes hesitated to accept them "because of what the neighbours would say." Furthermore, the proportion of those willing to take coloured students was considerably higher amongst working-class people than amongst those of a higher social and economic class. Fear of prestige loss was also found in an industrial setting in Shella Patterson's (1963) study of the coloured communtty in Brixton. Mrs. Patterson states that apprehension over status was shown by South London workers when they objected to an excessive proportion of coloured labour in any one department or shop, lest it should be regarded as a "black shop"; in a certaln tendency to regard some rough, unpleasant and low-paid jobs as "darkie jobs" and to shun them even more than before; and in the very widespread unw1llingness to contemplate taking orders from a coloured man.

However, the "colour/class-consclousness" theory cannot be accepted without reservations. For one thing, it is not strictly speaking a theory of prejudice; Little himself admits that people who lack "personal prejudice" may nevertheless feel compelled, by social pressures, to avold soclal contact with N egroes. If this is the case, then the theory is concerned more with social distance than with prejudice. This is not a serious difficulty; in the writer's view it is more an advantage than a liability. What is more important is the fact that, whether one uses the concept of prejudice or social distance, 
relations between white and coloured people in Great Britain cannot entirely be explained in terms of a simple relationship between colour and class-consciousness.

One difficulty is that the theory, as it stands, cannot adequately account for non-acceptance of Negroes on the part of working-class white people. ${ }^{1}$ One surely cannot argue that they too would be embarrassed by bringing the milkman or the grocer's boy into the house. Horeover, as Carey points out, some workingclass people doubtless regard coloured people as "beneath" them. But beneath them in what? For the "lowest" classes in the white community 1 t must be status not class considerations which are involved in this assumption of superiority. Thus Little's theory could perhaps more aptly be described as a "colour/status consclousness" theory of social distance.

As such, in view of the supporting evidence, it undoubtedly provides a partial explanation of the lack of social acceptance accorded coloured people in Britain. However, other considerations appear to be involved and in particular cultural factors. The latter are of considerable importance when the position of

1. W1 th regard to this question, Carey's assertion that the proportion of landladies willing to take coloured students was "considerably higher" amongst working-class people does, of course, provide some support for Little's theory. This evidence, however, is far from conclusive. The proportion of landladies willing to take coloured students was low in the case of both "working" and "upper class" people and the differences in acceptance rates between these two groups were in fact minimal. For Negro students the figure was $10 \%$ in both cases and for "lightly coloured non-Europeans" the proportions were $26 \%$ and $20 \%$ respectively. Furthermore, one cannot generalise too much on the basis of the students' lodgings situation. Shella Patterson's study showed that workers in Bouth London were concerned over matters of status, and Butterworth (1964) found, In a study carried out in Bradford during the General Election, that working-class people were less tolerant than the middle or upper class. 
the Asian immigrant is considered. In the Asian immigrant we have a coloured man whose skin colour is quite probably lighter than that of the Negro, but who is equally likely not to gain social acceptance. Of course, one could argue that like a dark skin, Asian features are symbolic of low status; but even if we ignore this possibility, lack of a comnon language and differences in norms and values would, in themselves, be sufficient to inhibit social integration. Bven in the case of Negroes, there are some differences in norms and values, especially in the case of the recently arrived immigrant. Thus, the possibility that cultural factors are involved here also cannot be excluded.

An attempt to incorporate Little's "colour/classconsciousness" theory into a more comprehensive theoretical Pramework was later made by Carey (1956). Carey's interpretation of colour prejudice begins with an analysis of the "psychological" factors which account for the existence of hostility towards outsiders. Briefly, he suggests that the ldentification with the father which results from the successful resolution of the Oedipus complex ensures that the hostility generated by the frustrations inherent in the socialisation process is directed against outsiders rather than the child's own group. For present purposes, however, this aspect of Carey's theory is of minimal importance. As Carey points out, "from a sociological point of view, it does not really matter in what particular way aggressive and hostile impulses are created ..... for the simple reason that hostillty may be expressed in more than one way." 
It may, and often does, take the form of colour prejudice, but need not necessarily do so. In different societies, the amount of racial hostility varies considerably, ranging from the situation in South Africa to the relative tolerance of Brazil with its generally favourable attitude towards interracial marriage. In Carey's view, it is the task of sociology to explain why the potential fund of hostility existing in all societies is so often directed against those of another race, rather than against members of other outgroups. The answer, he would suggest, lies in the peculiar nature of social differentiation based upon differences of physical appearance. In Brazil, Carey states, diacritical features ${ }^{1}$ which elsewhere have a high degree of permarence are socially interpreted in such a way that they become subject to change. The possession of acadenic qualifications or professional status, for example, is said to "whiten" Coloureds in the sense that they become socially the equal of Whites. In Britain, on the other hand, differences of physical appearance tend to be used to the exclusion of diacritical factors of other kinds. Thus all coloured people tend to be placed in one category irrespective of their other attributes; that is, they are regarded primarily as Coloureds, and such factors as nationality, social status, religious beliefs and so on, are only of secondary importance. As a result, Carey claims, social distance is created between white and coloured people, stereotypes are

1. 1.e., characteristics such as language and skin colour, tending to promote social distance. 
easily established, and the likelihood of hostility towards the out-group correspondingly increased. The out-group, by its very definition and by reason of the "different" values ascribed to it, is $1 i k e l y$ to be regarded as a competitor of the in-group and as a threat, implicit or otherwise, to its system of values. In the British situation, Carey suggests this threat derives from two sources: firstly, beliefs concerning the inferiority of coloured people, and in particular Negroes; and secondly, the stereotype of the Negro as a sexually uninhibited and highly potent being. The former, he states, gives rise to fears that association with coloured people will cause a loss in social prestige, and the latter arouses fear and hostility in that it constitutes a threat to midd le-class standards of conduct in matters of sex. These two factors, Carey suggests, are linked by the fact that, in Britain, uninhibited behaviour, particularly in matters of sex, is often regarded as evidence of 'low-class' social status. Moreover, he concludes, that because the fears and frustrations regarding sex are largely unconscious, they must be expressed in another way, and are in fact construed as a threat to social prestige rather than to the accepted standards of sexual behaviour.

It will be apparent, even from the short outline given above, that Carey's theory is one of considerable breadth. It draws together into a related whole several different theoretical concepts - the psycho-analytic view of prejudice, social differentiation, "colour/class-consciousness", sexual stereotypes 
concerning Negroes, and so on. Nevertheless, if the theory is to be employed as a complete interpretation of prejudice in Britain, 1 it encounters several difficulties, some of which have already been discussed in relation to Little's theory. Like Ilttle, Carey seems to assume too close a relationship between prejualce and discrimination. He states, for example, that landadies who are themselves favourably disposed towards Coloureds sometimes hesitate to accept them because of what the neighbours might say. Thus for this unspecifled, but perhaps quite high, proportion of landladies, explanations in terms of hostility produced by the frustrations of the socialisation process are largely irrelevant. It is conformity with the accepted standards of the group which is the crucial. factor. Moreover, this dramback is a more serious one in Carey's case than in Iittle's, in that he specifically attempts to relate discriminatory behaviour to 'psychological', i.e., personality, variables.

Further difficulties arise in Carey's attempt to explain discrimination which is motivated by hostility. Firstly, he states that one source of such hostility is the threat of sexual stereotypes concerning Negroes to middle-class standara s of conduct in matters of sex. But this leaves Carey with the problem of explaining working-class hostility towards Negores.

1. It $1 \mathrm{~s}$ not entirely clear from Carey's exposition whether he intends his theory to apply to the general pattern of race relations in Britain or merely to the situation encountered by Colonial students. For the present purpose, however, I have assumed the former to be the case. 
It would perhaps be legitimate to suggest that the Negro also constitutes a threat to lower class standards of conduct, but in this case the link between "low-class" social status and sexually uninhibited behaviour cannot be upheld. Secondly, If hostility towards coloured people is to be atrributed to the existence of stereotypes concerning the Negro, either as low class or sexually uninhibited, the problem arlses as to how hostility towards Asians is to be explained. It must be admitted that Carey found less discrimination in the case of Asian students, but the acceptance by landladies of "Ilghtly coloured non-Europeans" was nevertheless quite low: 20\% as against $10 \%$ for Negroes in one sample and $26 \%$ as against $10 \%$ for Negroes in the other. Furthermore, in my own study I found that, amongst British workers, social acceptance of Asians was lower than in the case of West Indians.

Here again, one may hypothesise that sexual stereotypes concerning Astan 1mmigrants also exist, but one wonders whether this is necessary. As Banton (1959) states, Carey "underestimates the extent to which hostility towards coloured immigrants is not displaced but direct aggression in that it is a rational response to certain kinds of situation." In Britain, the coloured man is often seen as a competitor for accommodation, for employment and for native British women. Under these circumstances, it is hardiy surprising that hostility towards coloured people should arise and should be accompanied by adverse stereotypes. But whether the stereotypes are the cause of this hostility or are merely rationalisations for 1 ts 
existence is an open question.

Another variable underestimated by Carey is the effect of cultural differences. He talks, for example, of social distance being created and of 'different' values being ascribed to coloured people. But when an immigrant group actually does have different values (which is to a large extent inevitable in view of the fact that they come from difierent cultural backgrounds), then sorne degree of social distance is only to be expected. In Carey's own stuay, he found some discrimination against continental Europeans and 'white' Dominion and United States students. Thus 'colour prejudice' cannot account for the whole situation, but only the greater social distance towards coloured people than would be expected in the case of any culturally difierent immigrant group.

In the next theory to be discussed, that of Richmond, differences in values are advanced as a central feature of intergroup relations. Richmond (1957) suggests that ethnic prejudice in Britain is a function of three main variables acting in conjunction: the existence within the community or two or more groups easily distinguished froin each other by a characteristic such as skin colour which is highly visible; the creation of false stereotyped ldeas concerning members of the out-group which impece the establishment of good personal relations between the two groups; and the existence of feelings of insecurity and frustration among members of the in-group. ${ }^{1}$ In Britain, Richmond

1. Blsewhere, these propositions are presented in the form of three interconnected hypotheses, the implications of which are intended to be of general application and not confined to Britain. (See Richmond, 1954 and 1958) This does not radically alter the theory, however, and for present purposes the above, somewhat shorter, exposition will suffice. 
(1957, 1958) claims, mild antipathy towards ethnic minorities is an institutionalised norm from which the extremes of prejudice and tolerance represent deviations. Such antipathy, he states, performs a positively integrative function for individuals and for the social systems in which they participate. It bolsters up the individual's self-esteem on the one hand and promotes group solidarity on the other. Richmond claims, however, that discrimination against coloured people as far as their everyday rights as citizens are concerned is not institutionalised in Britain. Nevertheless, he notes that although such rights are publically upheld, non-institutionalised discrimination in such spheres as housing, employment, recreation, and so on does occasionally occur, particularly when the individual perceives the out-group as a threat to his or her economic status or means of livelihood.

Richmond (1957) specifically rejects the view that prejudice is based upon class-consciousness. If this explanation were correct, he states, "then the visible distinguishing marks of class (such as accent, dress, ettiquette, occupation, etc.) would operate and the wealthy Negro with the Savile Row suit, polished manners and an Oxford accent would have no difficulty in being assimilated. In fact, although it is easier for such a person to gain acceptance, he is st1ll refected in certain c1rcumstances." R1chmond suggests, therefore, that: "It is not a question of the coloured man having low social status in our system of social stratification, but of him not fitting in at all." The social status of the Negro in Britain is amb1guous, 
and this gives rise to insecurity among whites who are not sure how they should behave towards them. This insecurity is agsravated by the belief that coloured people have different values, espectally with regard to sex. The essentlal point about any in-group - out-group delineation, Richmond concludes, is that the differences of skin colour (or whatever it is that visibly distinguishes the group concerned) are symbols of real or assumed afferences in values.

With its stress on differences in values, Richmond's theory goes some way towards overcoming the shortcomings of the "colour/class-consciousness" approach. Nevertheless it is subject to several other, quite serious, criticlsms. Like Little and Carey, Richmond atterpts to explain inter-personal relations between members of different social groups largely in terms of prejudice or feelings of antipathy. Antipathy lowards out-group members undoubtedly does occur, but it is highly questionable whether the pattern of relations between any two groups can be attributed solely to this factor. The fact that members of an out-group possess or are thought to possess different values is likely to give rise to some degree of social distance, but this does not necessarily mean that hostility towards them will occur. Instead, the group concerned may simply be avolded. Thus in cases where British people are able to "keep to themselves", hostility may not arise and an attitude of "live and let live" may prevail. Examples of such avoidance without hostility were in fact found amongst British workers in the course of the present study. 
Another questionable aspect of Richmond's approach concerns the prevalence of stereotypes about coloured people, upon which the theory is to a considerable extent dependent. Banton (1959) attempted to discover hov widespread were such stereotypes by means of an attitude survey. Only four per cent of respondents (11 out of 300 ) accepted the statement that "the coloured people who come here are uncivilised" and only nine per cent that "most of the coloured people here are very ignorant." A higher proportion, thirty per cent, accepted the statement that "coloured people have stronger sexual urges than white people." However, many qualified this by saying "at least, that's what I've heard," and others sald they had heard this, that it might be true, but they had no knowledge of it and would not therefore accept this as one of the statements with which they agreed. Banton concludes:

We can accept the view that there are many current bellefs about coloured people of an irrational character, totally lacking in scientific validity, without conceding these notions the status of stereotypes. They are received ideas, things people have heard said and to which they give a certain credence, but hardy anyone lives his iffe by them. The pragmatic attitude of finding out what people are like before judging them is far too strong for that.

Finally, Richmond's complete rejection of the "colour/classconsclousness" approach is not entirely convincing. For one thing, there remains the evidence of Carey and Patterson to account for. Richmond admits that non-institutionalised 
discrimination may occur in housing, employment and recreation, but attributes this to the threat to economic status or means of Iivelihood. However, Carey states that landladies were concerned with what the neighbours might say, not (or at least, not only) with the possible reactions of other tenants. This suggests, in addition to economic factors, social prestige amongst the peer group is also an important consideration. Furthermore, Richmond's argument against the "colour/classconsclousness" approach can equally well be applied to his own theory. It would be just as reasonable to suggest that the Negro who possessed the visible distinguishing marks of British social values (Savile Row suit, polished manners, Oxford accent and so on) should have no difficulty in gaining acceptance. If he does not, then the fact is no less damaging to Richmond's theory than It is to Little's or Carey's. As Carey pointed out, not all cues used in social differentiation are equally important: some, like race, are particularly salient and capable of overcoming many other considerations. But whether race, in this context, is symbollc of low social status or differences in values is not demonstrated by Richmond's argument.

In elther case, there would be ambiguities in the status of the Negro concerned. If Negroes in general are thought to have low social status, then the Negro in the Savile Row suit etc., presents a more than usually amblguous figure. One set of cues indicates that he has high status, whilst his race indicates another, much lower, status. Thus his difficulties in gaining acceptance can be attributed to the fact that British 
people are unsure of which status they should act in accordance with, and avoid the man as a means of avoiding this dilemma. We now turn to the theory of race relations in Britain advanced by Banton. This theory differs from those thus far examined in that it is not intended as a theory of prejudice. Banton (1959) makes a sharp distinction between prejudice as a state of mind, a disposition unfavourable to certain persons, 1 and discrimination which he defines as the differential treatment of persons ascribed to particular categories. Although prejudice and discrimination are often found together, Banton states, they are theoretically quite separate aspects of behaviour. Prejudiced people do not always discriminate; someone accustomed to treating coloured people in an inferior fashion will soon mend his ways in a country where he knows such behaviour will be disapproved or punished. Similarly, discrimination is not always the result of prejudice; a hotel manager who refuses accommodation to coloured people may only be carrying out the proprietor's instructions, and the proprietor himself may be well-disposed towards coloured people, but fear the loss of white custom. Thus

1. Banton later makes a further distinction between two types of unfavourable dispositions towards out-group members: firstly, prejudice per se which he defines as an emotional and rigidiy hostile disposition towards the members of a given group - an irrational and pathological phenomenon arising from the individual's own inadequacies and resulting in displaced aggression; and secondly, antipathy, a predisposition unfavourable to a particular group which results from ignorance, conflict of interests or some other objective factor, and thus can be modified by favourable experience of the group in question. In the above distinction between prejudice and discrimination, however, both types of unfavourable disposition would seem to be subsumed under the term prejudice. 
both the release of hostility and the expression of favourable attitudes towards coloured people are regulated by social factors, and it is these social factors, the sociological determinants of discrimination, with which Banton is mainly concerned in the present theory.

From the closing years of the elghteenth century, Banton claims, the doctrine that coloured people were fundamentally different from Europeans gained steadily increasing support. This he attributes to a variety of factors: the apologists for the slave trade who argued that the Negro was an inferior being, fit only for slavery and better off under a Christian master than left in ignorance; the growth of imperialism which fostered the belief that the lnglish were by nature destined to rule the inferior races of the world to the benefit of both; certain anthropological and blological doctrines which purported to demonstrate the racial superiority of Europeans; and the influence of the missionaries who were thought of as taking benefits to the heathen, doing for them things they were unable to do for themselves - superior to them in the same way as the teacher is to the pupil. By the early years of the twentieth century, Banton concludes:

...... the relationship between Britons and coloured colonials had developed into one in which Britons were thought to be socially and morally superior to their charges and responsible for their upbringing. Britons claimed rights consonant with their assumed obligations and expected colonials to conduct themselves as subordinates. 
In recent years, Banton suggests, this pattern of relationships has largely broken down. British people have come to realise that the old norms of conduct are no longer always appropriate, largely because coloured people refuse to enter into relationships on these terms. At the same time, relations between British and coloured people cannot yet be assimilated to the pattern of relations between Britons. Two reasons are given for this state of affairs. Firstly, coloured people are belleved to be unfamiliar with the norms by which these relations are governed and the ways in which the parties convey to each other their expectations and interpretations. The coloured man, Banton suggests, is seen as "the farthest removed of strangers - the archetypal stranger." Secondly, a dark skin colour detracts from a man's social prestige, and, where the nature of the relationship is not generally recognised or approved, from the prestige of those seen associating with nim. 1

Thus although the old norms have been discarded as a general guide to conduct, no agreement has yet been reached as to the principle which is to replace 1t. Owing to the ambiguities as to the proper course of conduct, Banton suggests, Britons are apt to avold entering into relations with coloured people,

1. Banton does not suggest, however, that all coloured colonials are thought of as socially inferior to all Britons. He states: "A coloured doctor is not ranked below a white shop assistant, nor an African chief below a typist. But unless he is known to be better qualified or more competent, $a$ coloured doctor will not be considered the equal of his white colleague. The coloured man always has to go one better to obtain an equal position." 
particularly in relationships based upon implicit norms and in which the sanctions upon deviant behaviour are weak. The Briton, he states, knows that awkward scenes may develop where people do not share the same customs and cannot take one another's hints; he feels the embarrassing scene acutely and avoids getting into a situation where it might arise. On the other hand, the coloured man is less likely to be avoided where the relationship is clearly defined and there exist adequate sanctions upon deviant behaviour. The employer, for example, is not unduly worried lest the coloured worker should prove lazy, because he can always give him the sack.

British behaviour towards coloured people, Banton concludes, cannot be explained as the outcome of prejudice. It is characterised not by aggressiveness but by avoidance of them in relationships which might get out of hand or which onlookers might regard unfavourably. There is discrimination, he states, but this does not represent an attempt to confine immigrants to a subordinate role in the national ilfe. It is a form of the avoidance of strangers that can be discerned in any society. Banton's theory is one of considerable explanatory power. It accounts for many of the different, and sometimes paradoxical, aspects of the British raclal scene. For example, why British people in general should be strongly opposed to discrimination in the public treatment of coloured immigrants and yet be so hesitant about treating them equally in private relations; why British conduct towards coloured people should be so uncertain and inclined to sudden change, and so on. of particular interest 
as far as the present study is concerned is Banton's analysis of a finding reported both in a British Institute of Public Opinion Poll (see Senior, 1956) and in Sheila Patterson's (1963) study of the coloured community in Brixton, namely that coloured immigrants are accepted to a much greater extent in the works than in the community environment. This Banton explains as follows:

In the course of his work (the Briton) may be brought into dealings w1th the 1mmigrants, but this gives him no cause for concern as his association is legitimised by the work relationship. If the newcomer does not understand the norms of the relationship this need not disturb the Briton, for the sanctions are such that if the coloured man fails to conform to the accepted usages, he may lose his job. This holds to a lesser extent of relations which are independent of the work process - such as with whom a man sits down in the canteen to eat his lunch, or in informal work arrangements that have not recelved the approval of the management. While in the district in which the British workers Iive the structure of relations may be quite radically different. They are not bound to mix with the newcomers, and if they do so they have little defence against elther the failure of the immigrant to behave in the expected fashion or the misinterpretation of the relationship by their neighbours. The workers' psychological make-up does not change when they come home from work; their different pattern of conduct is a response to a different social situation. 
This interpretation cannot be accepted in its entirety. The writer would doubt whether association with coloured people In the course of his work gives the British worker no cause for concern whatsoever. Certainly he tends to become anxious over his status and job security when a high proportion of immigrants are employed on his job, in his department or in the works as a whole. However, the important point is that the British worker does seem to be less concerned about associating with immigrants at work, and Banton's theory provides a most convineing explanation of this factor.

Similarly, except in matters of emphasis, there is little in the theory as a whole with which the writer would disagree. Banton perhaps places too much stress upon the absence of aggressiveness in British racial behaviour. The 'riots' in Nottingham and Notting Hill, the high feeling over the Immigration Act, and the racial tension arising in certain areas during the recent General Election all suggest that some hostility is present, even though it may be confined to a relatively small proportion of the population. Apart from this, however, the writer would accept in large measure both Banton's general theoretical approach and the specific hypotheses concerning race relations in Britain which he puts forward.

Having examined the four major theories of race relations in Britain, what conclusions may we draw? It would appear that the approach to race relations outlined in Chapter one is largely applicable to the British situation. Prejudice as an irrational and pathological personality tralt does exist amongst 
some members of the population but it cannot account for the behaviour of the majority of British people. ${ }^{1}$ This view is supported not only by Banton's survey of racial attitudes, but also by studies carried out by two American social scientists. The latter are particularly revealing in that the writers came to Britaln apparently expecting to find a replication of the American situation. Ruth Lardes, (1952) who came to this country to study mixed marriages, states:

Prejudice seemed to muddy up the approach; it didn't seem a helpful assumption in Britain.

Similarly, Burt (1960) writes:

It may even be possible to deny completely the existence of a race problem as such - a concept which would not be possible in discussing the United States - and to assert that the present situation in Britain is an 'immigrant problem' in which race is a complicating but not defining factor. One need not decide between the two concepts of 'race' and 'immigrant' problems; 1t is unnecessary legallsm to place social conflict under one rubric or the other. But

\footnotetext{
1. In the writer's view, there is much to be said for regarding prejudice as a form of "racial neurosis". In its extreme form it is comparatively rare, but like other neuroses, its symptoms can be found in a mild form amongst a high propcrtion of the general population. But to classify such people as prejudiced is analogous to describing someone as neurotic (in the clinical sense) simply because they have a compulsion to zo back and eheck the gas taps occasionally. Just as the term "neurotic" has been debased by its wide popular usage, so the term "prejudice" loses much of its usefulness when applied too generally to people whose behaviour is mainly influenced by social factors.
} 
1t is very important to keep in mind that we are able to account in great measure for the present social conflict by disregarding the fact that West Indian or African immigrants into Great Britaln are members of the Negro race.

We would suggest therefore that more light can be thrown on the racial situation in Britain if, instead of prejudice, the concepts of social distance and social conflict are employed. The social distance existing between white and coloured people in this country arises from a variety of sources. Of primary importance is the fact that the majority of coloured people in Britain are of immigrant origin; they come from different cultural backgrounds and have, to a greater or lesser degree, different norms and values. Under these circumstances, It is hardly surprising that they should have become to some extent segregated, both socially and geographically, from the host community. As writers such as Eisenstadt (1954) and Collins (1957) have polnted out, close social relationships between Immigrant and host are unlikely to develop in the early stages of any migratory movement. As strangers to each other, both the 1mmigrants and the members of the host community will tend to find more common ground for social relationships amongst their fellow countrymen than amongst members of the other group. In the case of coloured immigrants to Britain, however, the degree of social distance which occurs cannot be explained solely in terms of the cultural differences involved. The West Indians, for example, have more in common with British people in some respects than do the members of other immigrant 
groups. Yet they encounter more resistance than, say, a continental Buropean who does not speak English and is not interested in cricket. Similarly, the coloured man who has lived in Britain for many years and become thoroughly acclimatised to the British way of life may still be rejected socially. Other factors must therefore be taken into consideration. Firstly, the cultural bockground of the immigrants is sometimes thought to be more different from that of the host society than is in fact the case. For example, some British people express surprise that West Indians can speak English so well, or "explain" this by the fact that they are taught Finglish in the schools in Jamaica! Thus the immigrant may be regarded and treated as being a more "distant" stranger than he actually 1s.

Secondly, skin colour has a high "visibility" as a means of social differentiation, with the result that all coloured people tend to be placed in the same social category irrespective of their other attributes. Thus the coloured man is likely to be regarded as a recent immigrant even though other cues, less salient than his colour, indicate that he is fully conversant with British norms and values. ${ }^{1}$

Thlrdly, coloured people are generally regarded as

1. Banton (1959) states: "With his own acquaintances a coloured man may be known as a doctor, as a student, as someone who has lived in Britain for many years and knows all the British folbles - or he may even be someone born and brought up in this country. But to the man who does not know them each of these is as much a stranger as the latest arrival. It is their skin colour that is immediately noticed by someone meeting them for the first time, and that brands them as strangers." 
possessing lower status than British people in equivalent positions, which leads to avoidance due to the fear that loss of prestige may be incurred. The sallence of skin colour as a means of social differentiation is important here also. A coloured man may be a skilled worker of several years standing and may be known as such to his neighbours. Yet they may still fear loss of prestige because, due to his colour, he is likely to be classified as an unskilled labourer by someone who does not know him personally.

Finally, British people tend to avold associating with coloured Immigrants because they are unsure how they should behave towards them. They can no longer be treated invariably as soclal inferiors, because coloured people in general reject this form of relationship. On the other hand, they cannot be treated in the same way as other British people because they are thought of as strangers and because loss of prestige might result from such an association. Avoidance of coloured people occurs to a lesser extent, however, in the more formal type of relationsh1p where the behaviour of the participants is largely determined by their respective roles, misunderstandings concerning the nature of the relationship are less likely to occur, and the disapproval of onlookers (except where the Briton is in a subordinate position) less likely to be aroused. The above factors, in the writer's view, go some way towards explaining why coloured people in Britain are, in general, held at a greater social distance than might be expected if cultural factors alone were taken into account. 
Nevertheless, it must be remembered that the racial situation in this country is very fluid. Whilst the general pattern of relationships might be explained in these terms, there is also considerable variation. Thus close social relations between white and coloured people do occur, and in the very situations where concern over prestige and the tendency to avoid strangers might be expected to inhibit them. Similarly, social conflict also occurs, and it is to this aspect of the British racial scene which we now turn.

On the basis of his survey of racial attitudes, Banton (1959) concluded that the vast majority of British people were favourably disposed towards coloured immigrants. Whilst this may be the case as far as the general population is concerned, it appears to be less true in the areas of high coloured. concentration where, on a number of occasions, overt social conflict has arisen. In such areas, there exist several potential sources of friction which are unlikely to be present in the same degree elsewhere. Banton suggests that British racial behaviour is characterised by avoidance rather than aggression. But avoldance becomes increasingly difficult when large numbers of coloured people move into an area. For a variety of reasons, therefore, considerable resentment may arise amongst those British people unable or unwilling to leave the district.

Firstly, fears concerning loss of prestige are intensified; in particular anxiety arises lest the influx of immigrants should cause property values to fall. Secondly, the way of life of the 
immigrants may give offence to the British residents; for example, complaints are sometimes made concerning the smell of curry, noisy parties, houses not being kept clean, people sitting on door-steps or wearing hats indoors and so on. Thirdiy, the more immigrants there are in the area, the more difficult 1t becomes to establish and maintain group boundaries. Thus conflict may result where the immigrants attempt to overcome soclal distance and obtain full group menbership. 1 Pinally, hostillty towaras coloured people may occur due to the increased competition for housing, for jobs, and for wives and girl-friends. Resentment of the immigrants in this connection is particularly likely to arise when they are seen in the company of white women, where they obtain council houses ahead of white people as a result of being re-housed from condemned property, and during times of high unemployment. ${ }^{2}$

Thus far we have considered only realistic ${ }^{3}$ sources of conflict. However, the possibility of indirect aggression against coloured people must also be taken into account. The areas in whlch coloured people have settled in large numbers have tended

1. cf. Landes' (1952) statement that the Negro immigrant "guides himself in terms of the logic of complete acceptance, whereas Britons act in terms of a much more ilmited acceptance." 2. Richmond (1960) suggests that there is a connection between the suoden increase in juvenile unemployment in London and Nottingham during 1958 and the prominant part played by Juvenile gangs in the violence shown towards coloured people in these areas at this time.

3. See Coser's (1956) theory of social conflict outlined in Chapter 1. 
to be those which were already declining in prestige and becoming delapiaated, The frustrations of living in such a neighbourhood are all too apparent, and it would be hardy surprising if the coloured people were not sometimes used as a convenient scapegoat for the conditions which they may have aggravated but did not originally cause. Nevertheless, in view of the fact that so many sources of direct aggression exist in these areas, it would be unwise to over-emphasise the influence of unconscious factors.

Finaliy, it should be stressed that friction between white and coloured people is by no means inevitable in areas of high coloured concentration; overt conflict is in fact a comparatively rare occurrence. Nor is the above discussion intended as a complete interpretation of such conflict as does occur. However, conflict is more common in coloured areas, and the factor's we have examined seem most likely, on the basis of the evidence available, to be those which give rise to this situation.

\section{Summary}

In this chapter we have discussed three main aspects of race relations in Britain:

1. The historical background to immigration.

2. The position of coloured people in Britain in the post-war years, particularly in relation to housing and social acceptance.

3. The theorles which have been developed in an 


$$
\begin{aligned}
& \text { attempt to explain the pattern of relationships } \\
& \text { between white and coloured people which have } \\
& \text { arisen. }
\end{aligned}
$$

However, one aspect of the situation - that of employment has thus far largely been onitted from our discussion. It is to this topic which we turn in the next chapter. 
CHAPTER THREE

THE ECONOMIC BACKGROUND TO MIGRATION

\section{Preliminary Summary}

The sudden growth in coloured migration to Great Britain during the 'fifties was largely motivated by economic factors. The present chapter examines the skill level of the coloured immigrants in relation to the jobs available to them in this country. The immigrant, it will be argued, has tended to be somewhat less skilled than his British counterpart, and there was, during, the greater part of the 'fifties and early 'sixties, a considerable shortage of labour in British industry, especially in unskilled jobs. Nevertheless, there has been a general reluctance on the part of managements to employ coloured workers, and, in general, they have only done so when adequate white labour could not be oitsained. 


\section{Introduction}

In the study of the integration of any 1mmigrant group, two factors or sets of factors are vitally important before the first migrant sets foot in his country of destination. These are firstly the characteristics of the migrant population and secondly, the characteristics of the receiving situation. These may be termed the 'glven' or predisposing factors in a migratory movement and in large degree determine the subsequent course of the 1mmigration process.

By the characteristics of the immigrant population, I mean not only such attributes as the age and sex ratios, skills, both social and economic, ethnic membership and so on, but also the hopes and aspirations of the migrant group with regard to their new country. Similarly, the characteristics of the receiving situation include not only what might be termed the 'vacancies' which exist for new members of the community, but also the expectations of the host community towards the immigrant group. The form of adjustment which ensues between immigrant and host may be seen as the result of an interaction between these two sets of fa ors. The adjustment made will be mutually beneficial to the ertent to which the two sets of factors coincide and detrimental to the extent that they do not.

In the economic sphere, the characteristics of the migrant population and of the receiving situation with which we shall mainly be concerned, for the moment at least, are respectively the industrial skills of the various migrant groups and the employment position in Britain during the 'fifties. 
Other factors such as the immigrants' expectations concerning the type of work they were going to obtain and the beliefs of British employers concerning the type of work of which the immigrants were capable are also of importance, but these questions will be examined later.

2. The Level of Industrial Skill of Coloured Immigrants to the U.K.

Data collected in the course of the present research project are inadequate for the assessment of the general level of skill of the different migrant groups. Whilst information was obtained concerning the previous occupations of the coloured workers who were interviewed, it seems highly unlikely, in view of the manner in which the respondents were selected, that they constitute a representative cross-section of the coloured immigrants at present resident in this country.

It is necessary, therefore, to rely mainly upon the literature for this information. Unfortunately, the literature does not provide us with any clear cut answers. With regard to the skill level of west Indian immigrants, widely differing views have been expressed. On the one hand there is the statement in the House of Lords of the Earl of Swinton, that "the great majority of people who come to this country, certainly from the West Indies, are unskilled men."1 On the other hand, this view is strongly opposed by Ruth Glass (1960). On the basis of information obtained from a sample of West Indian immigrants

1. Parliamentary Debates, H.O.I., 19th November, 1958, col. 646 . 
In London, she claims that, in fact, "the 'great majority' of West Indians are black coated and skilled workers." Between these two extremes are the assessments of various other writers. In the Civil Service Argus (the official journal of the Ministry of Labour Staff Association) for February 1955, it was suggested that $13 \%$ of West Indian 1mmigrants were skilled, $22 \%$ were sem1-skilled and $65 \%$ were unskilled. In a survey carried out in the summer of 1961, however, the Economist Intelligence Unit (1962) found a much higher level of skill amongst West Indian migrants (see Table 8 ). Even if we recalculate the data to provide detalls of manual workers only, the occupational distribution is as follows: $42 \%$ skilled, $13 \%$ semi-skilled, and 45\% unskilled (Including agriculture and fishery).

Several studies of the skill level of West Indian migrants to Britain have been carried out in the West Indies. Maunder (1955) found that Jamalcan migrants tended to be drawn from the more skilled members of the general population. During October 1954, he interviewed 733 migrants as they left Kingston for Britain. The previous occupations of these subjects are presented in Table 3, the third column (\% in pop.) in the case of both men and women representing the distribution of these occupations in the population as a whole in 1943. The marked disparity between the occupational distribution of the migrants and that of the general population will be noted. Maunder states:

The evidence of table (3) is that the emigrants are educationally a superior group. Particularly striking are the high percentages with practical training or secondary education. 
He notes, however, that the considerable advance in standards for the general population since 1943. would go some way towards off-setting this disparity.

Table 3: Previous Occupations of Jamaican Migrants - October, 195.4

\begin{tabular}{|c|c|c|c|c|c|c|}
\hline \multirow[b]{2}{*}{ Occupational Group } & \multicolumn{3}{|c|}{ MEN } & \multicolumn{3}{|c|}{ WOMEN } \\
\hline & No. & $\%$ & $\begin{array}{l}\text { \% in } \\
\text { pop. }\end{array}$ & No. & $\%$ & $\begin{array}{l}\% \text { in } \\
\text { pop. }\end{array}$ \\
\hline (1) Ungkilled labourers & 22 & 5 & 24 & & & \\
\hline (2) Personal Service Occupations & 20 & 5 & 5 & 34 & 16 & 48 \\
\hline $\begin{array}{l}\text { (3) Famers, Fishemen and } \\
\text { Farm workers }\end{array}$ & 95 & 22 & 55 & & & \\
\hline (4) Seni-skilled workers & 36 & 8 & 5 & 14 & 6 & 2 \\
\hline (5) Handicraft workers & 57 & 14 & 5 & 122 & 56 & 12 \\
\hline (6) Skilled tradesmen & 154 & 36 & 8 & & & \\
\hline (7) Shop and Clerical workers & 36 & 8 & 7 & 22 & 15 & 7 \\
\hline (8) Miscellaneous & 8 & 2 & 1 & 15 & 7 & 32 \\
\hline Groups (1) to (8) & 428 & 100 & 100 & 217 & 100 & 100 \\
\hline $\begin{array}{l}\text { (9) No occupation but } \\
\text { sought work in } 1954\end{array}$ & 14 & & & 11 & & \\
\hline $\begin{array}{l}\text { (10) No occupation, no work } \\
\text { sought in } 1954\end{array}$ & 37 & & & 66 & & \\
\hline Groups (1) to (10) & 479 & & & 294 & & \\
\hline
\end{tabular}

More detailed information concerning the occupational level of Jamaican emigrants to Britain is given by Roberts and Mills (1958) whose data (see Table 4) cover the years 1953 to 
1955. As was the case in Maunder's survey, Roberts and Mills' data show a higher proportion of skilled tradesmen amongst the emigrants than in the population as a whole.

Table $4:$

Occupational Class of Male Departures from Janaica to the U.K. to seek work, $1953-1955$

\begin{tabular}{|c|c|c|c|c|c|c|c|c|}
\hline & \multicolumn{2}{|c|}{1953} & \multicolumn{2}{|c|}{1954} & \multicolumn{2}{|c|}{1955} & \multicolumn{2}{|c|}{$1953-55$} \\
\hline & No. & $\%$ & No. & \$8 & No. & क & No. & $\not 8$ \\
\hline 01. Planters & 7 & .6 & 12 & .2 & 27 & .2 & 36 & .2 \\
\hline 02. Farm workers & 259 & 12.4 & 740 & 14.3 & 2648 & 24.3 & 3547 & 20.4 \\
\hline 03. Carpenters & 207 & 16.1 & 906 & 27.5 & 1494 & 13.7 & 2607 & 15.0 \\
\hline 04. Masons & 66 & 5.1 & 368 & 7.1 & 650 & 6.0 & 2084 & 6.2 \\
\hline 05. Mechanics etc. & 242 & 18.9 & 1021 & 19.7 & 1915 & 17.6 & 3178 & 18.3 \\
\hline 06. Other skilled & 240 & 18.7 & 850 & 16.4 & 1667 & 15.3 & 2757 & 25.9 \\
\hline 07. Unskilled labourers & 72 & 5.6 & 252 & 4.9 & 729 & 6.7 & 1053 & 6.2 \\
\hline 08. Clerks etc. & 72 & 5.6 & 252 & 4.9 & 426 & 3.9 & 750 & 4.3 \\
\hline $\begin{array}{l}\text { 09. Senior persons in } \\
\text { trade etc. }\end{array}$ & 23 & 1.8 & 82 & 1.6 & 167 & 1.5 & 272 & 1.6 \\
\hline $\begin{array}{l}\text { 10. Executives and } \\
\text { Managers }\end{array}$ & 3 & .2 & 2 & - & 10 & .2 & 15 & .1 \\
\hline 11. Domestic workers & 15 & 1.2 & 79 & 1.5 & 242 & 2.3 & 236 & 2.4 \\
\hline $\begin{array}{l}\text { 12. Personal. Service } \\
\text { Proployees }\end{array}$ & 12 & .9 & 48 & .9 & 61 & .6 & 121 & .7 \\
\hline 13. Tailors & 86 & 6.7 & 288 & 5.6 & 555 & 5.1 & 929 & 5.4 \\
\hline 14. Nurses & - & - & 2 & - & 6 & .2 & 8 & .1 \\
\hline 15. Teachers & 2 & .2 & 7 & .1 & 43 & .4 & 62 & .4 \\
\hline 16. Civil Servants & 3 & .2 & 6 & .1 & 15 & .1 & 24 & .1 \\
\hline 27. Professionals & 29 & 1.5 & 33 & .6 & 57 & .5 & 209 & .6 \\
\hline 18. Others & 20 & 1.6 & 64 & 2.2 & 81 & .7 & 165 & 1.0 \\
\hline 19. No occupation given & 23 & 1.8 & 100 & 1.9 & 88 & .8 & 211 & 1.2 \\
\hline 20. Students & 13 & 1.0 & 56 & 2.1 & 136 & 1.3 & 205 & 1.2 \\
\hline 22. Others not employed & - & - & - & - & 4 & - & 4 & - \\
\hline Total & 1284 & & 5178 & & 10911 & & 17373 & \\
\hline
\end{tabular}


Roberts and Mills point out, however, that between 1953 and 1955, the total unskilled males emigrating to the United Kingdom experienced a fourteenfold rise, whereas there was only a sevenfold rise in the skilled. At first the emigrants had been mainly skilled and semi-skilled with a few unskilled, but by 1955 the position had largely been reversed. They conclude:

The departures of unskilled workers from the 1sland over the three year period strongly suggest that this phase of emigration may continue its increase into 1956 and that the unskilled, the rural awellers and the 111 iterates will appear in mounting proportions in the emigration stream to the United Kingdom after 1955.

During October 1955, a survey similar to that previously carried out by Maunder in Jamalca was undertaken in Barbados by Cumper (1957). A total of 384 emigrants (272 men and 112 women) from three boats embarking for Britain were interviewed. Data concerning the occupational distribution of the emigrants compared with that of the general population in 1955 is given in Table 5. Cumper states that in general the men were of a higher educational standard than the population as a whole comparable with the upper range of skilled persons in the general population.

Skilled workers were greatly over represented amongst the emigrants to an extent which does not appear explicable on the grounds of misreporting of occupation (it should be mentioned that the occupations declared by emigrants were 
checked against those shown on their passport applications). 1 Agricultural labourers were less common than in the whole population and so were the general labourers who make up most of the category 'Others' in Table (5). Among the male emigrants, white collar occupations were somewhat less common than in the whole population, but amongst the women the reverse was true mainly because of (a group of student nurses).

Table 5: Occupational Distribution of Enigrants from Rarbados, october, 1955

\begin{tabular}{|l|c|c|}
\hline \hline Men & o (emigrants) & (population) \\
Agricul tural labourers & 5 & 26 \\
Professional, clerical, salespeople & 12 & 16 \\
Skilled and Factory workers & 70 & 29 \\
Others (weinly general labourers) & 12 & 29 \\
\hline Women & & 31 \\
Africultural labourers clerical, salespeople & 23 & 13 \\
Professional, & 12 \\
Swall traders & 4 & 15 \\
Seamstresses & 42 & 23 \\
Domestics & 32 & 3 \\
others & - & \\
\hline
\end{tabular}

1. Parenthesis in original. 
Data on the occupational distribution of Dominican emigrants to Britain were collected by Davison and are presented in Table 6. A similar survey of the occupational level of Jamaican migrants was planned, but had to be abandoned for reasons to be given below.

Table 6: Claimed Occupations of Dominican Finigrants to the U.K.

\begin{tabular}{|lc|cc|}
\hline \hline A. Working for Wages & $\%$ & B. On own Account & $\%$ \\
1. Unskilled & 42 & 6. Pemoles & Dressmakers \\
2. Domestic servents & 15 & Housewives & 6 \\
3. Skilled & 34 & 7. Agricul tural peasant & 8 \\
4. Clerical & 6 & proprietors & 2 \\
5. Professional & 3 & 8. Shopkeepers & - \\
& & 9. Minors & 7 \\
\hline
\end{tabular}

Finally there is the data of Mrs. Alass which is based on a random sample of those West Indians who had been interviewed by the Migrant Services Division of the West Indies Commission. The total number of men in this sample was 782 , but in 174 cases (22\%) employment details were vague, employment status was unknown, or the person had definitely never worked before. Details of the previous employment of the remaining 608 men in the sample are given in Table 7, which, according to Mrs. Glass, 
w1ll provide no support for those people who write to newspapers complaining that England has become the "dumping ground of the world's riff-raff." 1 Indeed 1t does not, but whilst the writer has no desire to support such claims (which the data, not only of Mrs. Glass, but also of Maunder, Roberts and Mills, Cumper and Davison demonstrate to be completely without foundation), it must be pointed out that the contrary conclusion that the majority of West Indian migrants are black-coated and skilled workers, is itself questlonable on several grounds.

\begin{tabular}{|l|c|}
\hline \multicolumn{2}{|c|}{$\begin{array}{c}\text { Occupational Distribution of West Indian Migrants } \\
\text { in the 'London Sauple ' }\end{array}$} \\
\hline \hline Professional workers & 1 \\
Quasi-professional workers & 6 \\
Shopkeepers and Assistants, salesmen & 5 \\
Clerks, typists & 12 \\
Skilled manual workers & 46 \\
Semi-sikilled manual workers & 5 \\
Unskilled manuel workers & 13 \\
Farmers & 9 \\
Farm labourers, fisherwen & 3 \\
\end{tabular}

Let us assume for the moment that the data are accurate;

1. Quoted from letter to North London Press, 8th May, 1959. 
that is, that the statistics given represent the true skill level of the immigrants in the London Sample. What conclusions can be drawn from these data? It would seem evident that very few Immigrants were unskilled. Nevertheless, the proportion of unskilled immigrants may be higher than it at first appears. Farmers, farm labourers and fishermen are not classified with respect to skill but are placed in a different category from manual workers. However, once in Britain, they tend to become manual workers. Wood, for example, states that although coloured immigrants work in a variety of industrial jobs, there are hardly any in agriculture. This being the case, then as far as industrial work is concerned, the farmers, farm labourers and fishermen are unskilled. Not only this, they are amongst the most unskilled of the West Indian Immigrants, for not only do they lack speclfic industrlal skills, they also lack the general experience of working in industry which even the most unskilled manual worker has. If this is taken into account, then the proportion of unskilled workers becomes $25 \%$ not $13 \%$. In addition, there is the possibility that the 22 per cent of the sample for whom no occupational details were available contained a higher proportion of unskilled workers than the remainder of the sample. A man who has a skilled occupation would seem more likely to specify it than one who has not. Of course, this may not have been the case, but the possibility must be taken into account when drawing conclusions from the data.

Thus far we have concerned ourselves only with the London 
Sample, but obviously we wish to extrapolate these findings to a larger population. If this larger population is the total number of West Indians Interviewed by the Migrant Services Division, from which the sample was randomly selected, then there Is a high probab1lity that the sample 1s representative. If, on the other hand, the larger population is the total number of West Indians working in Britain, then the extrapolation is a much more dublous matter. Whether a migrant was interviewed by the Migrant Services Division depended upon whether the migrant himself chose to go there for assistance, 1.e., upon selfselection. There is no way of knowing, therefore, whether the Iondon Sample is representative of the population as a whole, and it may be that a disproportionate number of skilled migrants tended to make use of the facilities of the Migrant Services Division. Again, this may not be the case, but the fact that Roberts and M1Ils found a higher proportion of unskilled workers than Mrs. Glass and that this proportion was increasing suggests that the London Sample is skewed in the direction of the more sk1lled worker.

If we now drop the assumption that the data were accurate, further possibilities of error arise. Mrs. Glass's data depend for their val1dity upon reports by the 1mmigrants themselves. Th1s is also true of the other studies we have examined, w1th the exception of that of the Ministry of Labour Staff Association. Thus it is possible that the respondents exaggerated the amount of training they had received and the skills that they possessed, a point which is made by Roberts and M111s, and by Davison. The 
former state:

......the dubious nature of the claims to skill made by many of the emigrants should be emphasised, especially as some of them may deem it in their interest to profess such skills in the hope that they might thereby command a much better position In the United Kingdom.

Roberts and Mills found very few 1111 terates amongst the emigrants. However, an appreciable proportion of these 111iterates - $44 \%$ in 1954 and $25 \%$ in 1955 - declared themselves as possessing some skill, a fact which Roberts and Mills suggest is in keeping with the tenuous nature of some of the occupational classes delineated in their study.

Bimilarly, Davison states that, because it relies on personal reports and exaggeration might have occurred, his Dominican data "is of very doubtful value as an accurate assessment of the real sikill of the immigrants." Furthermore, he abandoned his attempt to obtain data concerning the previous occupations of a sample of Jamaican emigrants because rellable information could not be obtained.

A man would claim to be a "painter" or a "mechanic" simply because, in some remote past, ho had held a brush or a spanner in his hard or even watched someone handing these implements. Without some simple trade testing scheme, the attempt to register occupation simply on the word of the respondent seems pretty rutlie, especially when 1t is borne in mind that for the sake of prestige to say nothing of future employment prospects, it is a human reaction to exaggerate attained skill. 
Even when a more stringent check on accuracy is kept, however, errors may still occur. During World War II, skilled techniclans were recruited in Jamalca to help with the war effort (see Chapter Two, pages 76-77). Richmond (1954) reports that when the first three contingents arrived, "1t came to light that a considerable number of men had succeeded in convincing the authorities of their qualifications when in fact they had little or no skill."

Finally, there is the question of the standards by which the accuracy of the data is to be assessed. A man who thinks of himself as skilled and may, in fact, be skilled according to West Indlan standards, need not necessarily be skilled in relation to British criteria. Senior and Manley, in an enquiry carried out for the Janaican government, state that: "It is extremely difficult to transfer at the same level from one economic system to another the product of specific vocational training, apprenticesh1p, or industrial experience." Now this 1s often true even when the two countries concerned are at roughly the same level of economic development, but when the immigrant comes from an under-developed area such as the West Indies to one which is economically more advanced, then his kkill level may well fall conslderably below the required standards of his new country.

In relation to British requirements, the training received by West Indian immigrants may be inadequate in two respects. For one thing, it is likely to have been less rigorous and systematic than that recelved in Britain. Writing 
In 1953. Ella Campbell clalmed that: "For all practical purposes there is no apprenticeship system in Jamaica." She further states that the report of the Apprenticeship Committee of 1943 gave the following reasons for the unsatisfactory state of affairs w1th respect to apprenticeships, especially in the smaller industries and enterprises:

......the lack (1n most cases) or any system or training or well defined conditions of employment; the lack of co-ordination with the training offered by technical and vocational schools, little or no regard being paid to basic educational quallfications of apprentices or learners; the exploitation of juveniles by some employers who utilize nominal apprenticeships as a means of securing cheap labour; the attitude of some parents and guardians who are more interested in immediate increases of family income than in a career for the boys and girls they seek to place under apprenticeship; the tendency of apprentices and learners, under such conditions, to shift from one employment to another, or to open up in business on their own account before completing training; and the frequent abuse of the system by partially trained apprentices, who in the absence of regulations requiring certification of apprentice and master, are able, when they set up for themselves, to employ apprentices of their own.

Secondly, even when the training is of the highest standard, the equipment on which the apprentice is trained, and therefore the techniques whlch he can be taught, are likely to be less advanced than those used in Britain. Sentor and Manley 
state, for example, that several. immigrants who had correctly looked upon themselves as skilled lathe turners in West Indian plants told the same story of being sent by British Bmployment Bxchanges to work as turners, only to find that the measurement was done with micrometers instead of callpers and that they were expected to achleve the much finer tolerances indicated by the former.

Considerations such as these were taken into account by Cumper in his analysis of his aata. He suggests that skilled workers were over-represented to an extent which does not seem explicable on the grounds of misrepresentation of data, but emphasises that the term 'skilled worker' is used in Table 5 to denote those who would reasonably so classify themselves In Barbados. In an ecciony with more advanced technical standards, he states, many would be regarded as semi-skilled or unskilled. Similarly, Roberts and M1lls state that throughout their study, "the occupational classes designated skilled in terms of conventional West Indian standards bear little relation to the classes of skilled workers as understood in Great Britain."

We may conclude, therefore, that Mrs, Glass's assessment represents an overstatement of the skill level of West Indian immigrants. It 1s, of course, impossible to specify the exact degree of error involved, but my own opinion is that it is probably quite large and that the estimate of the Ministry of Lshogr staff Association is much more realist1c, at least as far as manual workers are concerned. The fact remains, however, 
that whilst the majority of West Indian Immigrants may be unskilled by British standards, they are amongst the most sk1lled workers in the West Indian economy. Th1s state of affairs is one which, as Wood (1960) points out, is very 11kely to give rise to misunderstandings and difficulties. He states:

Some (West Indians) were well taught at home, but there are fairly widespread complaints that some who think they are skilled fall short of the standards demanded by craft unions and employers In this country. This is often felt by West Indians to be an unfair discrimination made because of their skin colour, whereas, in fact, 1t is usualiy an objective decislon based on professional standards of skill. (Italics mine)

Wuch lese research has been carried out with respect to the occupational distribution of other groups of coloured 1mmigrants. The only systematic study known to the writer is the Economist Intelligence Unit's (1962) survey carried out in the summer of 1961. Details were obtalned of the previous occupations of seven 1mmigrant groups including West Indians, Indians and Pakistan1s. These data are presented in Table 8. It w1ll be seen that al though more Indians and Pakistanis fall into the "Professional" "Business and Managerlal", and "office and clerical" categorles, there are more skilled manual workers in the West Indlan group. 
Pable 8: Percentage Distribution of Previous Occupations of Coloured Inenigrants in Britain, Sumer 1961

\begin{tabular}{|l|r|r|r|}
\hline \hline & west Indians & Indians & Pakistanis \\
Professional & 2 & 8 & 4 \\
Business and Managerial & 1 & 10 & 6 \\
Office and Clerical & 2 & 2 & 4 \\
Skilled Manuel Work & 28 & 14 & 8 \\
Semi-skilled Manual Work & 9 & 5 & 4 \\
Unskilled Manual Work & 18 & 2 & 9 \\
Nursing and Welfare Work & 2 & - & - \\
Agriculture, Fishing & 12 & 14 & 19 \\
Students too young to Work & 3 & 13 & 9 \\
Unemployed & 12 & 14 & 165 \\
Other answers & 11 & 83 & \\
\hline Number in Sesmple & 603 & & 31 \\
\hline
\end{tabular}

To some extent this coincides with Wood's (1960) assessment that: "Amongst the West Indians there are more skilled workers than amongst other nationalities." If, however, we recalculate the data to provide detalls of manual workers only (see Table 9), we find a similar proportion of skilled workers amongst Indians and West Indians. The findings are also contrary to Desai's (1963) conclusion that:

Most (Indian immigrants) ${ }^{1}$ have an agricultural background, the great majority belonging to the

1. It should be noted that Desal defines as immigrants "Those who came (to Britain) to work, usually as unskilled or semiskilled labourers, in order to pay for their stay and earn money." The remainder - students, qualified medical practitioners, technical trainees, business men, High Commission officials and so on - are not defined as immigrants and do not come within the scope of his study. 
agricultural castes. The rest are usually craftsmen who depend for their livelihood on the agricultural castes.

\begin{tabular}{|l|c|c|c|}
\hline \multirow{2}{*}{ Teble 9: } & \multicolumn{4}{|c|}{$\begin{array}{c}\text { Percentage Distribution of Previous Occupations of } \\
\text { West Indian, Indian end Pakistani Manual Workers }\end{array}$} \\
\hline & West Indian & Indian & Pakistani \\
\cline { 2 - 4 } Skilled & 42 & 40 & 15 \\
Semi-skilled & 13 & 14 & 8 \\
Unskilled & 27 & 6 & 17 \\
Agriculture, Fishing & 18 & 40 & 60 \\
\hline Total Number in Sample & 403 & 29 & 86 \\
\hline
\end{tabular}

In view of the smallness of the sample, therefore, it seems Iikely that the Economist Intelligence Unit's survey overestimates the number of skilled workers amongst the Indian group.

The occupational distribution of the Pakistani immigrants, on the other hand, largely corresponds w1th other assessments which have been made. According to Kathleen Hunter, most of the Pakistani manual workers, who form the largest section of their co-nationals in Britain, have come from villages where factories and their purposes are largely unknown. Similarly, Alav1 states that the Pakistanis who came to Britain in the postwar years $\ldots . .$. . 
......were often men who had seen little outside their village. Those who were literate amongst them knew Bengal1, but very few knew Inglish. They were quite unsophisticated in their ways and bound very much by custom and traditional modes of behaviour. 1

If It is accepted that a high proportion of Indian and Pakistani manual workers came from such rural backgrounds, then there is little doubt that, on the whole, thelr opportunities for developing industrial skills were much more limited than in the case of the West Indians. However, to describe these rural lmmigrants simply as "unskilled" could be misleading. The mere fact of growing up in an industrialised community provides even the most unskilled worker with a background knowledge and experience of industry and industrial methods. Te can also speak the language of that community, and can therefore be told how to do relatively simple tasks in a short time. This applies In the case of the West Indian worker to almost the same degree as the native British worker. But it is much less true of Indian and Pakistani immigrants, in that, firstly, they tend to lack industrial sophistication, and secondly, the majority cannot speak Bnglish. This means that not only do they have to be trained for specifis skilled or semi-skilled jobs, but in many cases they may also have to be taught how to be unskilled labourers.

1. The 1mmigrants who arrived prior to and immediately following the Second World War, Alavi states, had been more sophisticated. Small in numbers, they were malnly ex-sailors and ex-soldiers who had "seen the world." They were detribalIsed, Individualistic, and tended to adopt Brit1sh ways much more readily than those who were to follow. 
To summar1se: the writer is of the opinion that West Indian Immigrants are in general less skilled than native British workers. Although the data are conflicting, it seems likely that the estimate of the Ministry of Labour Staff Association of $13 \%$ skilled, $22 \%$ semi-skilled and $65 \%$ unskilled, is the most realistic assessment of the skill level of manual workers in this group of immigrants. Such evidence as there is indicates that Indian and Pakistani 1mmigrants are, on the whole, less skilled than the West Indian 1mmigrants, both with respect to specific industrial skills and industrial sophistisation. Their lack of facility with the English language is an additional handicap and, in effect, lowers their skill level even further.

\section{The Bmployment Position in Britain during the 'Plfties}

Unt1l the late $1940^{\circ}$ s the coloured worker was a comparative rarity in British industry. Admittediy, coloured workers were employed in industries essential to the war effort during both World Wars, but except in times of national emergency, British firms seem to have been reluctant to eiploy coloured labour. In fact, during the inter-war years, Iittle tells us, sea-faring was the only occupation in which the coloured worker had any chance of obtaining employment, and even here, opportunities were to a considerable extent limited. Between 1948 and 1960, however, work in industry became increasingly avallable to coloured immigrants. The large concentrations of the coloured population shifted from the ports 
to the large inland industrial centres. Whereas the 'old'

immigrants consisted mainly of sailors who had settled in the ports, the 'new' immigrants came specifically to obtain jobs in industry. Firms which had never done so before, began to employ coloured workers. Of the firms from which data were obtained in the present study, only two had employed coloured workers for more than 30 years and only three as far back as World War II. In the remaining 54 cases, coloured workers were first employed between 1947 and 1960. What brought about this dramatic change in policy on the part of these firms?

Writing in 1956, Senior related the increase in Britain's coloured population directly to changes in the supply of labour. He states that the unfavourable effects of out-migration on the expanding war and post-war economy, together with a long term decline in the British rate of natural increase had combined to produce a declining rate of growth in the labour force. One result had been that in only two of the previous ten years, 1947 and 1952, had the number of unfilled vacancies registered at Labour Bxchanges at mid-year failed to exceed the number of unemployed. In June 1956, for example, there had been a total of 223,000 unemployed and 397,000 vacancies, or a total deficit of 174,000 persons. 1

It was this desperate shortage of labour which was filled

1. Quoted from "Britain's Manpower Situation" Labour and Industry in Britain March, 1956. pp. 7 - 10. It should be noted that the demand for labour decreased sharply during the following two years, 1957 and 1958, due to a trade recession. Coloured immigration to Great Britain slackened during this period, but increased again after the state of trade improved. 
in part by the large-scale immigration of coloured people. However, the vacancies open to coloured people, Sentor claims, were not spread evenly throughout industry. There had been a tendency for British workers to move from industries in which the value of output was low to those where it was higher, thus leaving the lower paid and the 'dead-end' jobs to be filled by the newcomers. Such jobs, though unwanted by the British workers, represented greater economic opportunities than were afforded by the colonial areas.

Senior's account of the economic background to coloured immigration in the post-war years is largely supported by data from the present study. The employment of coloured workers as a means of overcoming a shortage of labour was a recurrent theme in most of the firms visited in the course of the interview surveys. When asked why their firms had begun to employ coloured workers, four managers said succinctly:

We couldn't get enough non-coloured labour.

(Works Director, Torrington Cutlers)

Shortage of labour - we had no alternative really.

(Pactory Personnel officer, Leigham Cannery)

Labour was tight in that day.

(Personnel Manager, Sterling Metal Co.)

Shortage of white labour.

(Works Manager, Annerley Iron Foundry)

Others, however, went into greater deta1l and it might be worth examining these examples further as several interesting 
points arise. Some of the firms, for example, first turned to foreign white workers, such as Poles, Italians, Irish and so on, in an attempt to solve their labour shortage. These firms later employed coloured workers, e1ther because they st11l could not obtain enough workers or because the foreign white workers had proved unsatisfactory.

The big influx of immigrant labour began in 1954. At this time you couldn't get an armless, legless man, never mind an able bodied one. Any worker could leave the works and get a job literally within three or four minutes simply by going to the factory next door. We tried recruiting Irish labour but this didn't come off. The Manager went over to Ireland himself and recrulted 36 men. Of these, only 8 actually turned up at the works, and only one stayed for any length of time.

(Works Superintendent, Bradfield Foundry)

The first forelgn labour we employed were German and Itallan prisoners of war. When these men were repatriated, the firm found 1tself short of labour. Poles were employed and a number still work here. They were very good workers, but we couldn't get enough to make up for the labour shortage. The Ministry of Labour had coloured people. We wouldn't look at them at first, but eventually we succumbed. It was a case of necessity: there was no one else. Well, there was the Irish, but they were dreadrul. Only about one in twenty was any good.

(Labour Manager, Edge Tools Itd.) 
After the war there was firstly a shortage of workers, and secondly, a sense of freedom amongst the workers generated by the attitude of the people coming home from the forces. They felt that because they had fought for freedom, they deserved a job, and could pick and choose, so they didn't like settling down. We tried employing continentals and refugees, etc., but 1t didn't work out in our industry. The Chairman after the war wouldn't have foreigners (this meant coloured workers). He died in 1949, and in 1950 the succeeding Chalrman employed Indian workers.

(Labour Officer, Westwood Foundry)

We began employing coloured workers in 1958. At that time we were having labour trouble, especially with the Irish. You didn't know on a Monday morning whether you would have 40 men at work or 20, and by Wednesday, you might have 50. So we got in touch with the local employment exchange and asked them if they could send some rellable men along. They recommended a Pakistan1. We were a bit dubious at f1rst, but we took him on.

(Works Manager, Omega Metals Ltd.)

Orten managers made 1t quite plain that it had not been a general shortage of labour which had led them to employ coloured workers, but a shortage of labourers to do the kind of job which was least attractive to the British worker.

We began employing coloured workers in 1956. You couldn't get a good white worker unless you were prepared to pay over the odds, and good coloured people are better than bad white people. You can't get white people to do the 
menial tasks that have to be done in any foundry, not even the floating workers like the Irish.

(General Manager, Stainless Steel Ltd.)

There was a shortage of labour and coloured workers were avallable. There were certain jobs the white workers steered away from and the coloured workers filled the bill. Up to three years ago you couldn't get a white labourer. Things are different now, of course.

(Personnel Manager, Soverelgn Steel Works)

We first employed coloured workers in 1951. The primary reason was the great difficulty in recrulting foundry labourers. We were particularly hard hit in the foundry.

(Personnel Manager, Major Castings Itd.)

It wasn't easy to obtain unskilled labour. Non-coloured labour won't have 1t. It's hard work under rather bad conditions.

(Production Services Manager, Blackford Rolling M11ls)

In another case, the manager indicated that it was possible to obtaln some white workers but these were of a prohibitively low standard.

In the early 'fifties, white labour was virtually impossible to get. You could only get what we call tramps: he doesn't want to work and wants his money for nothing. They stay for a couple of months, then leave. Then later on they come back for their job again. We set some of these drifters on four or five times. Then the Arabs came. We set two on - one was a brick, the other a dud. The dud couldn't speak English. We got 
rid of him, but replaced him w1th another Arab. We have a contact man, an Inglish-speaking Arab, who brings men when we need them.

(Works D1rector, Steel Bars Itd.)

In all, ten ${ }^{1}$ of the fourteen firms visited during the non-directive survey had employed coloured immigrants as a result of difficulties in obtaining white workers, either in sufficient numbers or of an adequate standard. In the remaining four firms, no mention was made of the initial reason for employing coloured labour. In the directive interview survey, managers in twelve ${ }^{2}$ of the seventeen firms directly attributed the employment of coloured workers to the labour shortage, and it was mentioned as a possible contributing factor in two further cases. ${ }^{3}$ In another firm, the manager stated:

We could get the coloured worker to do a job at a smaller rate of pay, st11l within union agreements, but which would not interest the white workers.

(Personnel Officer, Quality Steel C.)

In effect, the reason here is again shortage of labour. The lower pald jobs were open to coloured workers because the white workers were not prepared to do the jobs at that rate of pay.

In the remaining two cases, managers sald that coloured

1. Firms $2,3,5,6,7,8,11,12,13,14$.

2. Firms 17, 27.

3. Firms 15, 18, 19, 20, 21, 22, 23, 24, 26, 28, 29, 30. (For 1dentification of the above firms see Appendix I.) 
workers were employed for reasons other than shortage of labour.

We never had any trouble with labour shortage, so unlike several other firms in the area we were never placed in the position of having to employ coloured labour. As a result, as a firm, we turned our face against coloured workmen. Th1s bothered me, and I suggested to the Board on several occasions, that we should employ some coloured workers as a matter of policy. Eventually it was agreed that we should. After having seen the difficulties other firms in the area had had, we decided it was essential to employ only inglish speaking coloured labour. This meant West Indians only.

(Personnel Manager, Pentland Alloys Ltd.)

It happened by coincidence. We weren't really looking for coloured labour. We needed a boller firer and this man (a Pakistani) needed a job, so we took him on. A year or elghteen months later, he asked for a job for his nephew. He was employed as an annealer. He was so good at his job that we employed other Pakistanis and they took over these jobs under a white man. And then other jobs were given to Pakistanis. It is left up to the managers of the different departments as to whether they will take coloured workers. They won't take West Ind1ans and some won't take Ir1sh. Some won't accept Pakistanis or any coloured people, and one won't take Irish, but w1ll take Pakistanis.

(Personnel Manager, Ridgeway Steel Ltd.)

Thus, al though neither firm employed coloured workers because of a shortage of labour, a resistance to the employment 
of coloured workers is still evident. In the first example, this resistance was only overcome because one man (the Personnel Manager) felt that it was wrong to exclude coloured workers from employment, and managed to bring the rest of the management round to hls way of thinking. Nevertheless, only West Indlans were employed, and, as we shall see later, these men were employed only in restricted numbers, and on certain restricted jobs. In the other case, coloured workers were employed on their merits and w1thout reference to any labour shortage. Even here, however, only Pakistanis are employed and then only in certain departments.

Further evidence of the relation of labour supply to the employment opporturities of coloured workers was found in two firms, visited for purposes of comparison, which did not employ coloured labour. Both were situated on the outskirts of the industrial centre and were able to obtain sufficient workers from the immediate vicinity. In both cases, this adequate supply of local labour was advanced as the reason why coloured workers had never been employed. In one firm, there had been a meeting between management and the workers to discuss the recrultment of coloured labour. According to the Personnel Manager, the workmen were of the same opinion as management: "They weren't against employing coloured labour, but they didn't see any reason to do so while there were local people out of work." Nevertheless, the firm had employed Poles in 1947. Thus, apparently, foreign white workers are employed at a time when there is no shortage of labour but coloured workers are not. 
In the other firm, the Personnel Manager stated that if it came to a choice between employing coloured labour and closing down part of the works, then undoubtedly coloured workers would be employed. But, he added, this situation had never arisen.

Finally, in the questionnaire survey, managers were asked to indicate why coloured workers had first been employed in their firms. The answers are given in Table 10.

Tuble 10: Reasons given for Initial Braployment of Coloured Workers (Questionnaire Survey)

\begin{tabular}{|c|c|c|}
\hline & No. & $\%$ \\
\hline 1. Lack of alternative sources of labour & 19 & 51.4 \\
\hline 2. Huwanitarian reasons & 1 & 2.7 \\
\hline 3. As a matter of course when they becane available & 10 & 27.0 \\
\hline 4. (1) and (2j) & 2 & 5.4 \\
\hline 5. (1) and (3) & 2 & 5.4 \\
\hline 6. (1), (2) and (3) & 3 & 8.2 \\
\hline 7. Any other reasons & - & - \\
\hline & 37 & 200 \\
\hline
\end{tabular}

It w11l be seen that the main reason given was shortage of labour alone, or shortage of labour in combination with other factors. In one case, it should be added, it was claimed that coloured workers were employed "as a natter of course," but the respondent wrote at the end of the questionnaire: "We do not usually employ coloured people simply because we can get all the white labour we require." 
Taken together, the interviews and questionnaire surveys demonstrate a general reluctance to employ coloured workers, which, in the main, is overcome only when adequate alternative sources of labour are not available. Furthermore, the interview survey indicates that the shortage of labour and thus the distribution of jobs available to coloured people did not occur evenly throughout status levels. Generally speaking, the coloured worker tended to obtain the jobs which the white workers valued least - foundry labourers in Major Castings Itd., the "menial tasks" In the Quality Steel Co., the labouring jobs which the white workers "steered away from" In the Sovereign Steel Works, and so on.

Thus the present data amply supports Senior's thesis concerning the economic basis of the large scale immigration from the Commonwealth during the 'fifties. Without the severe shortage of labour, it seems highly unlikely that more than a small minority of the coloured immigrants who actually came to Britain would have been able to find jobs and support themselves. At first sight, those data also seem to support Senior's further contention that the enipluyient avallable to coloured workers was in the lower pald and "dead-end" jobs in industries where the value of output was low. However, this is not entirely the case. No doubt Brit1sh workers did tend to avold these jobs, but the present study shows that jobs which were relatively highly paid, or provided relatively good opportunities for promotion, or were in industries in which the value of output was high (although perhaps not all three), were also in some cases avolded, 
thus providing employment opportunities for coloured workers. Industries in which the value of output is low do not have a monopoly of the lower paid and 'dead-end' jobs. Even in the most successful industries there are likely to be requirements for, say, sweepers-up, general labourers, window cleaners, and so on, and one cannot assume that British workers will be any more prepared to do these jobs in an expanding than in a declining industry. To take only two examples from the present sample of firms, nelther Precision Engineers Ltd., a light engineering firm of national repute, nor Westwood Foundry, which was undertaking a million pound expansion programme in 1962, could be called firms in which the value of output was low. Yet both had difficulty in recruiting labour and both resorted to the employment of coloured workers to overcome this problem.

Money is, of course, an important consideration as far as the attractiveness of a job is concerned. In Stainless Steel Ltd. and Quality Steel Co., managers Indicated that they could have obtalned white workers to do the lower status jobs providing they had been prepared to pay higher wages than was usual. On the other hand, the moulders employed in Bradfield Foundry were in relatively highly pald skilled jobs, and yet white workers st1ll avoided them, presumably because they were dirty and strenuous, to such an extent that it became necessary to employ European and coloured workers.

Similarly, not all the jobs on whlch coloured workers were employed, could be described as 'dead-end' jobs. Brierley Metal Works and Westwood Foundry had a policy of promoting their 
own employees when a skilled vacancy occurred rather than employing an already skilled worker from outside. There was therefore a very good chance that promotion would occur, yet white workers were not prepared to accept a lower status job even on what was in all probability a temporary basis. Again, In the Quality Steel Co., coloured workers were employed on the lower grades of set work, the first step in the promotion ladder, so this could hardly be described as a 'dead-end' job. of course, the fact that it would not be a 'dead-end' job to a white worker does not mean that promotion would necessarlly be open to a coloured worker, but this is another matter which w11l be examined in the next chapter.

Thus Senior's assessment of the employment opportunities for coloured workers seems to be tos narrow. Coloured workers could obtain Jobs which were not lower paid, or were not 'dead-end', or were not in industries where the value of output was low. Where they $d i d$, however, it was usually because these jobs were avolded by white workers for other reasons, e.g., they were dirty, strenuous, tedious and so on. One is reminded of Ruth Landes' description of the coloured man's attitude towards life in Britain.

Sure there's freedom in Britain, but a man don't stand a chance. In the States, there's Jim Crow, sure. Only certain jobs and so on. But he gets., any job he goes after. Here the job disappears with a black face. With the Yanks you know where you are. Here you don't. But you learn this much: you can have what the Englishman don't want. You 
can have the room he won't live in, the job he won't take, and the woman he throws out.

As far as employment is concerned, the present data provide considerable justification for this assessment of the situation. Indeed, it would appear that in one respect the man underestimates his case. In City Transport and Precision Engineers recruiting trips were made to Ireland and to Italy respectively. In other firms, Polish, Italian, Irish and other foreign white nationalities were employed before coloured workers were turned to, more or less as a last resort. All this suggests that the coloured worker does not automatically get the job the Englishman won't take: he may only get those which foreign white workers do not want either.

\section{Summary}

In this chapter we have concluded that: a) coloured Immigrants have, in general, been less skilled than British workers; b) amongst the various coloured groups, West Indians are both more skilled and more industrially sophisticated than Asian immigrants, and have a considerable additional advantage in speaking English as their native language; and c) during most of the 'fifties, owing to an acute labour shortage, there were a large number of vacancies in British industry, especially in unskilled jobs. The extent to which the immigrants' qualifications and the vacancies avallable to them were compatible, it is suggested, played a major role in stimulating the largescale Immigration from the Commonwealth during the post-war years. 
On the basis of this evidence alone, two things might seem to follow: firstly, that the immigrants would experience relatively little difficulty in achieving a satisfactory level of accommodation within the British industrial system; and secondly, that employers would have a marked preference for West Indian workers as a result of their obvious advantages over the other immigrant groups. To a large extent, however, neither turned out to be the case, for reasons which we will examine in subsequent chapters. 


\begin{abstract}
CHAPTER FOUR
INTEGRATION INTO THE WORK ORGANISATION:

BMPLOYMENT AND OCCUPATIONAL LESYELS
\end{abstract}

\title{
Preliminary Summary
}

Although there is some variation between different coloured groups, the employment level of coloured workers tends to be lower than that of native British workers. Similarly, coloured workers tend to obtain jobs of a lower occupational status. This situation cannot be explained in terms of any single determinant, but is the result of a number of factors, (the skills of the immigrants, managerial beliefs, the attitude of the white workers, and so on) acting in conjunction. The present chapter has two main aims: firstly to establish what the comparative employment and uccupational levels are; and secondly to outline the various factors involved, some of which are examined in greater detall in later chapters. 


\section{Introduction}

In the previous chapter, we discussed the conditions under which coloured immigrants were first employed in a number of firms. It was concluded that, owing to a reluctance on the part of managements to employ coloured workers and the uneven distribution of job vacancies, they tended to be introduced only when sufficient white workers could not be obtained and tended to be given the unskilled, labouring type of jobs which whlte workers valued least. The question still remains, however, as to the effect of these initial. conditions upon the subsequent employment pattern of coloured workers in this country - whether, in fact, this represents merely an initial phase in the adjustment process or a more rigid situation with long-term repercussions. We now turn, therefore, to an examination of the present employment position of coloured workers in order to ascertain what progress, if any, has becn inare towards industrial integration. In this we shall follow the scheme outlined in Chapter One, (pages 51-59). For the moment, however, we shall be concerned only with the questions of employment and occupational levels. Consideration of the treatment accorded coloured workers by managers and supervisors will be delayed unt1l we have examined the general question of supervision in a later chapter.

2. The Employment Level of Coloured Workers

(a) Bmployment Statisties

In 1960, Judith Henderson stated: "In places where there is a coloured community, there are generally many more unemployed 
amongst them than amongst the surrounding group of whites." Several studies support this assessment of the situation. Richmond's (1961) estimate of the unemployment rate amongst Negro seamen on Merseyside is given in Figure 1.

\section{Figure 1: White and Coloured Unemployment on Merseyside} $1930-1950$

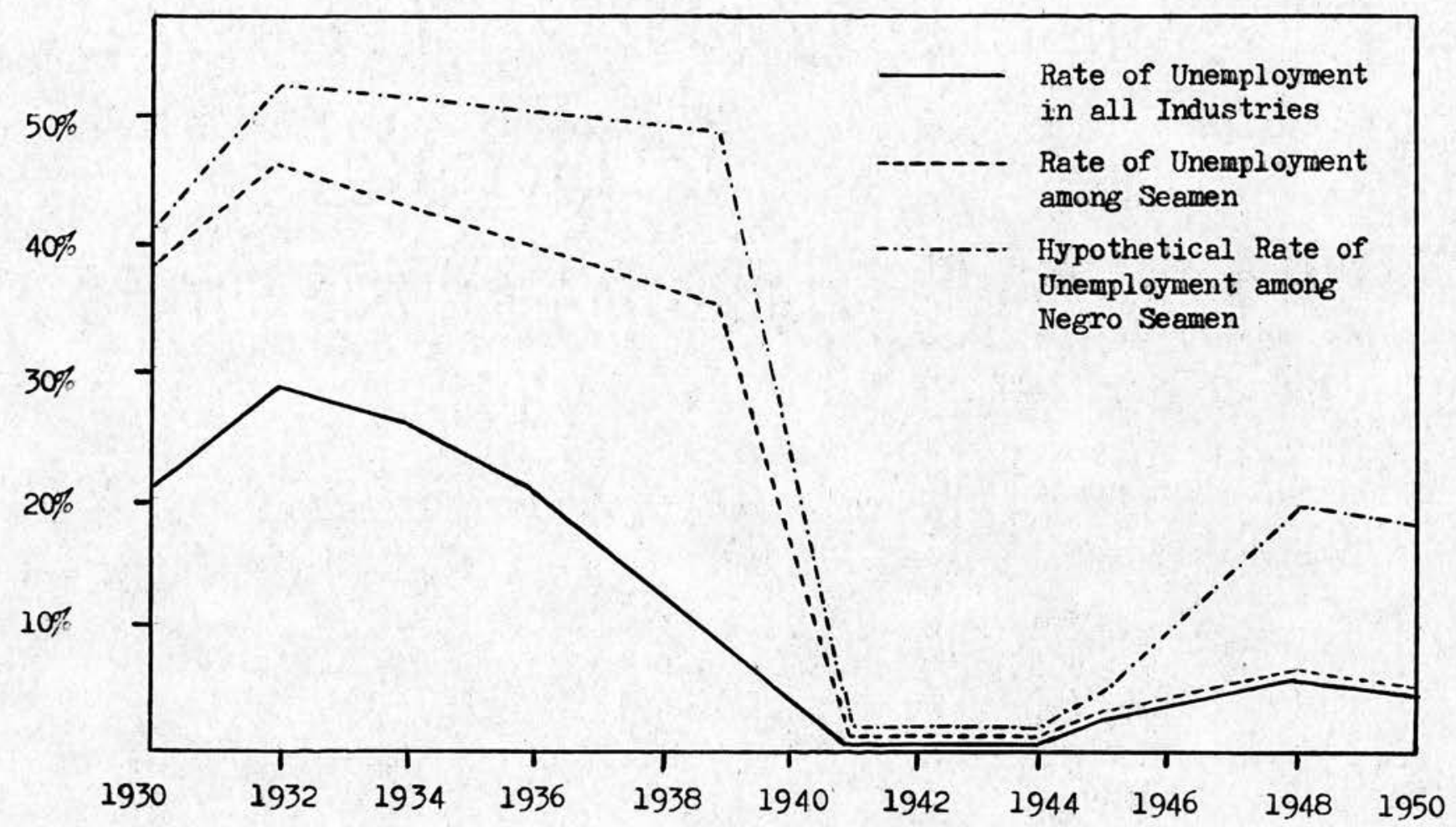

It will be seen that although Negro and white unemployment was at a similar low level during the Second World War, Negro unemployment rose much more rapidly than white in the post-war years, and by 1948 was some three times higher. Richmond states 
that since 1950 the position in Liverpool has remained much the same with unemployment amongst coloured colonial workers fluctuating between 15 and 20 per cent. ${ }^{1}$ Banton (1955) found a similar rate of unemployment (approximately 15\%) amongst coloured workers in East London in 1951.

Wickenden states that in 1958 about $14 \frac{1}{2}$ per cent of the coloured people in Nottingham were unemployed, while the figure for the whole population, white and coloured, was less than 1 per cent. According to Argyle (1964), "Unemployment is much higher amongst the coloured population - $30 \%$ v. $1 \frac{1}{2} \%$ in one area." Unfortunately, he does not name the area nor give the source of his data.

In May 1962, the East and West Riding Regional Board for Industry (quoted The Guardian, 16th May, 1962) gave figures of the number of unemployed immigrants compared with the total unemployed in Leeds, Sheffield, Bradford, Huddersfield and Halifax. These data are presented in Table 11.

\begin{tabular}{|c|c|c|c|}
\hline Table 11 : & $\begin{array}{l}\text { White and Coloured } \\
\text { May } 1962\end{array}$ & Uneraployment in Five York & Lire Towns; \\
\hline & Total Uneraployed & Imaigrants Unerployed & Percentage \\
\hline Leeds & 2913 & 351 & 12 \\
\hline Sheffield & 3797 & 449 & 12 \\
\hline Bredford & 3367 & 2168 & 64 \\
\hline Hudderafield & 2284 & 423 & 33 \\
\hline Halifax & 595 & 173 & 29 \\
\hline
\end{tabular}

1. By Pebruary 1963, however, it would appear that this was no longer the case. According to the Regional office of the Ministry of Labour (quoted The Guardian, 4th Pebruary, 1963) only 373 of an estimated 10,000 coloured people living on Merseyside were registered as unemployed. This represented only $0.8 \%$ of the total unemployed in the district. 
In the Midlands, according to the Midland Regional Board for Industry (quoted The Guardian, 28th February, 1962), the proportion of coloured workers amongst the unemployed had risen from $8.8 \%$ in February 1961 to $21.8 \%$ in February 1962. It is impossible to araw firm conclusions from either of the above sets of data because the proportion of coloured workers in the total working populations of these areas is not known. However, given that the proportion of coloured workers in the total working population of the country was $0.6 \%$ in $1961,{ }^{1}$ then the unemployment rate amongst coloured workers was probably much higher than amongst white, even allowing for a wide margin of error due to regional variations and an increase in the coloured population since 1961.

In a Parliamentary answer (Hansard Vol. 634, No. 56, 17th February, 1961, quoted Patterson, 1963) it was stated in February 1961 that the coloured unemployment rate was about five per cent, compared with the national average of 1.9 per cent. A similar unemployment rate ( 5 per cent) was found amongst Commonwealth immigrants in a fleld survey carried out by the Economist Intelligence Unit (1962) in the summer of 1961. However, the respondents in this survey included white Commonwealth immigrants as well as coloured, and the coloured rate of employment tended to be higher than average. West Indians had the highest rate of unemployment at 9 per cent and the rates for

1. The Bconomist Intelligence Unit (1962) gave the total number of Commonwealth Immigrants registered for work with the Ministry of Pensions and National Insurance as 144,400 in 1961 and the total working population for the same year as $24,590,000$. 
Pakistanis and Indians were 7 per cent and 5 per cent respectively. All these rates were substantially higher than the 1.6 per cent average rate of unemployment in the United Kingdom in mid 1961.

On the basis of a survey carried out by the Institute of Race Relations in 1959, Wood (1960) concluded that:

Coloured unemployment rates are ....... everywhere higher than the corresponding white figures....... no-one knows the exact coloured population of any one town, but it seems certain that the coloured rate is at least twice as high as the white rate and probabiy higher. Almost certainly the rate is higher among Indians and Pakistanis than among West Indians.

Wood suggests that in times of economic recession, as in 1957/8, coloured workers are particularly hard hit by the shortage of jobs. In the boom conditions of 1955-56, many coloured immigrants found jobs within a week of their arrival. Two years later many newcomers were unemployed for elght weeks or longer. As the unemployment rate goes down for white workers, he states, it also goes down for coloured workers, but more slowly.

Wood's assessment of the effect of the 1957-58 recession on employment prospects for coloured workers is supported by other evidence. Senior and Manley (1958) stated in 1955 that difficulties connected with making a living were, after housing, the next most frequently mentioned by their respondents (both coloured immigrants and those working with them). However, the difficulties were mainly concerned with finding a job which came up to the immigrant's expectations: seldom was there any 
problem reported in actually finding employment. The situation was soon to change, however, and by 1958 wickenden reports that employment had become the main problem with housing second.

The growth of coloured unemployment during this period is examined by Sheila Patterson (1963). As early as May 1956, she states, there was evidence that coloured workers were becoming more difficult to place in such centres as Brixton, Birmingham, Manchester and Iiverpool. By September 1956, the Parliamentary Secretary to the Ministry of Labour (The Times, 19th October, 1956, quoted Patterson) declared that the number of unemployed coloured workers had risen to 6,800 , sin increase of about 1,500 over the previous quarter. ${ }^{1}$ The total unemployment rate at this time was 208,000 ; thus the proportion of coloured workers in this total was 3.3 per cent. Given that the proportion of coloured workers in the total working population was $0.6 \%$ in 1961 and that the coloured working population had increased between 1956 and 1961, then this represents a much higher rate of unemployment amongst coloured workers than amongst white.

In June 1957, Mrs, Patterson atates, reports from areas of coloured settlement indicated a considerable, if temporary, improvement in the employment situation. At the same time,

1. It should be noted, however, that during the period the total number of coloured workers in jobs had risen by 6,000 . According to Mrs. Patterson, "It must be taken Into account that a steady stream of new arrivals ( 9,000 from the West Indies alone) was coming onto the labour market during the same period. 
however, the Ministry of Labour reported that it was taking much longer to place immigrants than in previous years. This indicates, as Wood suggests, that coloured employment rates go up more slowly than white after a period of high unemployment. By the autumn of 1957, the number of unemployed coloured immigrants was about 7,500 out of a total unemployed of 268,000 (2.8\%). Thus although the number of coloured unemployed had increased since the previous year, their proportion of the total unemployed had actually fallen. However, the number of unemployed coloured workers doubled over the winter to 15,000 in March 1958, when the total unemployment count was 433,000 (Hansard, 4th April, 1958, quoted Mrs. Patterson). ${ }^{1}$ This entalled a rise in the coloured proportion of the unemployed to $3.5 \%$. At the end of July 1958, according to the Rt. Hon. R. A. Butler (Liverpool Daily Post, 6th September, 1958, quoted Patterson) the coloured unemployment count was over 17,000. This represented a coloured unemployment rate of about $8 \%$ compared with the national average of under $3 \%$, according to a statement in the House of Lords on 19th November, 1958. At the end of 1958, the coloured unemployment count was down to 14,300 (Hansard, 5th December, 1958, quoted Patterson), but rose again to a peak figure of 17,000 coloured unemployed in February 1959. After March 1959, however, the unemployment situation improved rapidiy and no further reports on the coloured count rose by only 2000 to 6,500 . 
unemployed seem to have been published in 1959 and 1960, a fact which in 1tself, Mrs. Patterson suggests, is an indication that the employment of coloured labour had ceased to be a major source of concern and friction. She notes, however, that by early 1961, Mr. Norman Pannel, M.P., was citing increased unemployment figures for coloured migrants following the peak migration year of 1960 , and that a government spokesman admitted that the coloured unemployment rate was about 5 per cent compared with the national average of 1.9 per cent (Hansard, 17th February, 1961, quoted Patterson).

Thus the high unemployment rates sometimes reported, for example, Wickenden in 1958, can be partly, though by no means entirely, explained by the ract that the rate of unemployment amongst coloured workers is abnormally high during a period of recession and it is, of course, at just these times when statements about coloured unemploynent tend to be made. The recession of $1962 / 3$ could perhaps partly explain the high rates of unemployment amongst coloured workers reported by the Reglonal Board for Industry of the Bast and West Ridings and the Midlands, (see above) in May 1962 and Pebruary 1962, respectively. Another factor which may also have been relevant was the approaching Immigration Act which took effect from July 1962. This Iine of argument is developed by Davison (1964).

To support his thesis, Davison analysed Ministry of Labour statistics of coloured unemployment between 1960 and 1963. These data are presented in Table 12. It w1ll be seen that unemployment amongst coloured people rose steadily from 
August 1960 until May 1962 and then declined sharply until November 1962. During the severe winter of $1962 / 3$, when general unemployment rose to a post-war record, unemployment amongst coloured people also rose, but not to the peak which had been

\section{Table 12 : Coloured Unemployment in Great Britain $1960-1963$}

\begin{tabular}{|l|c|c|c|}
\hline \hline Month & $\begin{array}{c}\text { (1) Total Registered } \\
\text { Unemployed (in } \\
\text { thousands) }\end{array}$ & $\begin{array}{c}\text { (2) Coloured Uneraployed } \\
\text { (in thousands) }\end{array}$ & $\begin{array}{l}\text { Col. (2) } \\
\text { as percentage of } \\
\text { Col. (1) }\end{array}$ \\
\hline August 1960 & 322 & 8.4 & 2.6 \\
November 1960 & 352 & 11.7 & 3.3 \\
February 1961 & 390 & 14.3 & 3.6 \\
May 1961 & 300 & 15.1 & 5.0 \\
August 1961 & 305 & 13.9 & 4.5 \\
November 1961 & 388 & 21.7 & 5.5 \\
February 1962 & 454 & 31.7 & 6.9 \\
May 1962 & 424 & 38.6 & 9.1 \\
August 1962 & 464 & 31.8 & 6.8 \\
November 1962 & 545 & 28.5 & 5.2 \\
February 1963 & 878 & 35.3 & 4.0 \\
Nay 1963 & 518 & 25.4 & 5.0 \\
\hline
\end{tabular}

reached in the previous May. Davison claims that there can be little doubt that the increase both in absolute numbers and in proportion of coloured unemployed from August 1960, when the coloured unemployed constituted less than three per cent of the total registered unemployed, to May 1962, when they constituted nine per cent, was directly due to the threat of the Commonwealth Immigrants Act which came into operation on 1st July, 1962. While the Bill was passing through Parliament, Davison states, that travel agents in the Commonwealth worked overtime packing every 
available ship and 'plane with immigrants hurrying to Britain to 'beat the ban'. Very few of them came with a job in prospect and they crowded the Employment Exchanges seeking work, thus causing unusually high coloured unemployment figures. ${ }^{1}$

After the Act came into operation, the proportion of coloured unemployment fell back until it reached 4 per cent in February 1963, but rose again slightly to 5 per cent in May 1963. During the preceding winter (1962-63), unemployment generally rose 61 per cent between November and February whereas coloured unemployment rose by only 24 per cent. Thus the proportion of coloured workers unemployed fell during the period of general heavy unemployment. Thus there are no grounds, Davison states, for belleving that coloured workers are an undue drag on the labour force. If anything, he concluded, the high geographical and industrial mobility of the newly arrived coloured immigrants makes them an asset rather than a liability. Having no roots in Britain, they are willing to settle in areas where their labour is most needed and to take jobs which the unemployed Englishman refuses to take.

1. It was also alleged that some firms used the impending Immigration Act as an excuse for refusing jobs to coloured workers. Mr. Z. I. Qureshi, vice-president of the Pakistani Welfare Association (quoted The Guardian 18th September, 1961) stated that factory managers and foremen in some areas had recently started to tell coloured applicants: "We have no jobs for you. Why do you apply when you know you will all be going back to your own countries because of the new B11l." Whether these firms would have found some other excuse for not employing coloured workers had the Immigration Bill not been convenient, it is, of course impossible to say. 
There is much in what Davison says. Banton (1959) reports, for example, that there was considerable apprehension in Birmingham in January 1956 when the coloured unemployment count was 600 at a time when workers in the Midlands motor factories were being laid off and a general recession threatened. By August, however, there were no more than 700 unemployed coloured workers in Birmingham, many of them new arrivals. Discharged coloured workers had moved fairly readily to the North West where there was a surplus of vacancies. Inquiries by the National Assistance Board carried out at about this time showed that there was no "hard core" of coloured unemployed. In other words, the higher rate of unemployment amongst coloured workers was due to the fact that they suffered from somewhat longer periods of unemployment between jobs, rather than from permanent or long term unemployment.

From the point of view of the country as a whole, therefore, it would seem that the somewhat higher rates of unemployment amongst coloured workers is a small price to pay for the advantage of a large group of workers with higher geographical and industrial mobility than the native British worker. However, this does not invalidate our original contention that the unemployment rate amongst coloured workers is higher. Davison himself concludes that the average rate of coloured unemployment during the period 1956-1962 was probably about ten per cent compared with the usual national average of under two per cent. Obviously, then, employment opportunities for coloured workers are more limited than for white workers. The remainder of this section 
will be devoted to an examination of what these limitations are.

(b) Factors Limiting Employment Opportunities for Coloured Workers

With respect to individual firms, these limitations can be reduced to two types: firms which employ no coloured workers and firms which do employ coloured workers but limit their number in one way or another. The Ministry of Labour Staff Association, in its official journal Civil Service Argus for February 1955, reported on an analysis of the occupations in which the largest number of vacancies were to be found. It stated that "only about half of them (were) likely to be avallable to coloured workers because the following factors had to be taken into account:- skill, location, colour prejudice, work which is done by both sexes, the attitude of trade unions and the type of work." We shall begin by examining these factors in relation to firms which employ no coloured workers.

The effect of location upon the range of jobs available to coloured workers was mentioned in Chapter One. However, the question is quite complex and requires more detailed examination. According to Wood:

In towns where coloured people have gone for the first time during the past ten years there are no ghetto-like "coloured quarters" Iike in some American cities. But there are concentrations of coloured people in certain districts. New arrivals go to these areas where friends and compatriots live and a "snowballing" process begins.

There are probably many factors which contribute to the 
formation of these"concentrations". D1scrimination in housing and accommodation is undoubtediy one, as is lack or seniority on Counc1l house walting 11sts. In addition, lack of funds to buy the better type of house in these towns and lack of soclal integration into the host community (leading coloured people to prefer the security and companionshlp of living amongst their compatriots in the 'coloured quarters' to the uncertalnties of the white world outside) may also be relevant. Thus, in as much as such factors as the above $11 \mathrm{mit}$ the range of jobs available to coloured workers to those within reasonable travelling distance of the "coloured quarters", then these limitations may be said to result from extra-1ndustrial factors.

However, th1s differentiation between industrlal factors (e.g., skill, managerial discrimination, etc.) and extraIndustrial factors such as housing, is an arbitrary theoretical distinction. In practice, both may be relevant even in areas where there are very few coloured people or none at all. Some coloured workers are prepared to travel comparatively long distances to work if employment nearer home cannot be obtained. Thus to advance the argument, as one manager I interviewed did, 1 that a f1rm does not employ cololured workers because there are none in the district may be somewhat specious. Whilst it is

1. The firm in question was the first of the two firms already mentloned on page 161, which employed no coloured workers and were visited by the writer for purposes of comparison. The above reason for the lack of coloured workers in the labcux force was advanced in addition to the fact that there was no shortage of white workers. 
true that the firm was situated some five or six miles from the nearest concentration of coloured people, so was Hamilton Engineering Co. and this did not deter coloured workers from working there. Furthermore, coloured workers had approached the firm for jobs, so obviously they were prepared to undertake the long journey to and from the firm or to find nearer accommodation had they been offered jobs.

In fact, it is probably the case that it is the avallability of employment which gives rise to coloured settlements in certain areas rather than avallability of housing. Housing discrimination and so on may determine the district in which they settle within the area, but coloured people would not move into the area as a whole, no matter how easy it was to obtain accommodation, unless they could obtain work there. In most of the large industrial areas in Bngland, London, the Birmingham conurbation, Manchester, Liverpool, Leeds, Sheffield, Bradford, Newcastle and so on, there are now areas of coloured settlement, and often more than one. It is doubtful whether any job within these areas and also the outlying districts would be so far away from the centres of coloured population as to be unavailable to coloured workers on the grounds of location. Where the question of location may be relevant is in the smaller industrial towns which have not yet attracted coloured settlement, but it is also likely that there are only a limited number of vacancies in these areas in any case.

We turn now to the firms within areas of coloured settlement which employ no coloured workers. It is evident that 
although coloured workers are avallable to these firms, there is nevertheless considerable resistance to their employment. In Chapter Three 1t was suggested that, in general, firms did not employ coloured workers unless a shortage of labour left them no alternative. Unfortunately, no clear conception of the proportion of firms not employing coloured labour can be gained from the present data. The postal questionnaire was designed primarily to provide some test of the generality of the interview dats, and was, therefore, sent mainly to firms where it was known that coloured workers were employed or where it was thought 1ikely that they would be. Nevertheless, 29 per cent of the firms from which data were obtained reported that they did not employ coloured workers. No doubt the figures would have been much hlgher had random sampling been used. The question of firms refusing to employ coloured workers recently gave rise to a controversy in the letter columns of a national newspaper. ${ }^{1}$ The point at issue was whether it was better for Fmployment Bxchanges not to send coloured workers to employers who had let it be known that they would not accept them, thus protecting the coloured worker from the possible humiliation and discouragement of rejection, or to send them to these firms and thus at least give them the opportunity of speaking for themselves. ${ }^{2}$

1. See Ietters to the Baitor, The Guardian, $27 \mathrm{th}, 30 \mathrm{th}$ Hay, and $1 \mathrm{st}, 5 \mathrm{th}, 9 \mathrm{th}, 11 \mathrm{th}, 15 \mathrm{th}$ June, 1964.

2. Another point made by some of the writers was that by not sending coloured workers to prejudiced employers, they were, in effect, condoning discrimination, and that the practice was reprehensible for this reason. 
According to the inltial letter and also Frank $F$. Lee, (1960) Employment Exchanges employ the former method. Lee refers to this as a form of 'structured shielding', i.e., the protection of coloured people from experiencing discrimination. With reference to Port $\mathrm{Clty}$, the pseudonym for an industrial town of nearly half a million population in the south-west of England, Lee states that "there are many firms ....... that will hire no coloured workers regardless of the labour shortage or their qualifications." Similarly, one of the correspondents noted above, a youth employment officer, stated that she would like to say that if any employer discriminated against coloured people, they would refuse to send him anyone else, but they were so numerous that this would be impossible to carry out. ${ }^{1}$

Several reasons can be advanced for this resistance to the employment of coloured workers: an adverse assessment of the standard of coloured workers, managerial prejudice, fear of racial friction, objections from the white workers, and so on. Very few of the 25 flrms in the postal questionnalre survey employing no coloured workers gave any reason for not doing so. of the few that did, the most common explanation was that there was no shortage of white workers. But this is only a partial explanation. It takes for granted a preference for white and coloured workers when both are avallable, but does not give any reason for this preference. In these cases, the hidden reason may be one of those mentioned above (adverse assessment of the stancard of coloured workers and so on). On the other 
hand, it may be a question of sheer inertia. Never having been forced seriously to consider the employment of coloured workers, some managers may feel it is best to 'leave well alone' rather than to take a chance on an unknown quantity. 1

The question of skill has already been discussed in Chapter Three, and w1ll be examined further in Chapter Five when we w1ll analyse managerial bellefs and attitudes towards the employment of coloured workers. A discussion of the part played by managerial prejudice in limiting the number of jobs open to coloured workers is no easy matter. It $18 \mathrm{highly}$ unlikely that any manager, when asked why he does not employ coloured labour, w1ll say, "Because I'm prejucilced" or "Because I just don't like them." Instead, he will give reasons such as "Because they are not skilled enough." Now this may be a rationalisation, in which case we can say that prejudice, though perhaps of an unconscious nature, is involved. On the other hand, he may be quite justified, especially if the job is of a highly skilled nature, and no prejudice may be involved. Thus

1. With regard to American industry in the Northern states, Myrdal (1944) states: "There are tremendous elements of Inertia which resist the introduction of Negro labour where there has previously been none.", (p. 392-3) He claims that Negro labour can be introduced successfuliy, provided employers are prepared to go to some lengths to obtain the white workers acquiescence, but adds: "Under ordinary c1rcumstances, however, there are few employers who would take so much trouble voluntarily, just for the purpose of contributing to the solution of the race problem. After all, the employer's main interest is to run a business. To continue to employ white labor only is always the easier way out." (p. 389) 
when faced with such a response, each individual case must be examined on its merits. ${ }^{1}$ This question is also examined in Chapter Five.

Another reason for the reluctance to employ coloured workers is the fear, not always justified, that racial friction might ensue. According to the Works Superintendent of Bradfield Foundry :

When we first began employing coloured workers, I envisaged race riots and all kinds of trouble, but by and large they have settled down and been accepted.

It has been suggested that, due to jealousy on the part of white workers, friction is particularly likely to arise when coloured men are employed in the same department as white women. Work which is done by both sexes was noted by the Civil Service Argus (see above) as one of the factors decreasing the number of jobs available to coloured workers. It would appear, then, that there is a tendency for firms to avoid such friction simply by not

\footnotetext{
1. If the response is "Because racial friction might arise", the situation is even more complex for, objectively speaking, the manager is right. The fact that many other firms have employed coloured workers without friction arising does not prove that there is not a chance, however remote, that it will on this occasion. The question is then a moral one: how far the manager concerned is justified in putting the firm's interests before those of society as a whole. Whether the man is prejudiced or not will depend upon whether he is genuinely acting in the firm's interests or is merely using his loyalty to the firm as a means of hiding his own personal bias. As the man quite probably does not know himself, some sort of depth interview would be needed to discover the answer. It is this kind of consideration which makes the writer dubious about the value of the concept of prejudice in studies such as the present one. On the other hand, there is no doubt that the man is discriminating, whatever his reasons, latent or manifest, for doing so.
} 
employing coloured men under conditions where they are likely to come into contact with white women.

Owing to the limited data obtained from firms not employing coloured workers, it is impossible to come to any firm conclusion concerning the prevalence of this state of affairs on the basis of the present evidence. Only two firms mentioned this question. One stated:

We do not employ coloured workers - the whole of our production staff is female and we feel that we would have some difficulties if we introduced coloured labour into the factory. The supply of labour in this district is sufficient for our requirements both on actual production and for ancillaries such as labourers, etc.

In the other case, it was apparently the white women who objected to the employment of coloured men, ${ }^{1}$ although the firm had employed West Indian women as machine operators since June 1960. The respondent stated:

Only on one occasion did we employ coloured men. This seemed to upset our female employees and we were obliged to cease employing coloured men.

On the other hand, it should be pointed out that in at least three of the interview survey firms (Bradfield Foundry, Edge Tools and Sovereign Steel Works) white women and coloured men worked in close proximity and no friction ensuing from this situation was reported by any of the managers concerned.

1. N.B. It may be that the previous respondent had also been concerned about the possible objections from white women rather than men, as he did not stipulate the nature of the "difficulties" which he thought might arise if coloured men were employed. 
The situation sometimes arises (as in the case reported above) where management is prepared to accept coloured workers, but the white employees object. One of the firms in the postal survey replied:

We have never been short of "white" labour (unskilled) and on one occastion only were we, as a company, prepared to accept coloured labour, but the men on the shop floor were not agreeable which attitude we accepted.

Another firm employing no coloured workers returned most of the questionnaire blank but gave the following answers to two of the questions:

a) Was there any initial resistance to the employment of coloured workers? ................There 1s!:

b) Are the white employees willing to accept coloured workers as work-mates? ......................!

The respondent stated that one of the major objections was over the coloured workers use of tollets. Other complaints included slovenliness and idleness. In this case, however, the respondent did not state whether management would have been prepared to accept coloured workers even if there had been no objections from white workers.

Resistance to the employment of coloured workers on the part of wh1te employees has perhaps recelved most publicity with respect to public transport. According to press reports, 'bus company employees in several towns (e.g., Bristol, Coventry, West Bromw1ch, Birmingham, Wolverhampton, Nottingham and Newcastle upon Tyne) and also railway workers in Birmingham and 
London have at various times objected to the employment of coloured workers. ${ }^{1}$ In these cases, pressure was brought to bear on management, often by threats of strike action or work to rule, not to employ coloured workers. Where there is a closed shop, the same effect is sometimes attained by slightly different means: coloured workers are excluded simply by refusing them union membership (usually on grounds of inadequate training). In the writer's experience, this tends to limit the range of jobs avallable to coloured workers within a firm rather than to exclude them altogether, but here again this may be an arteract due to the fact that most of the firms studied in the present research employed at least some coloured workers. We now turn to the further limitations of the employment level of coloured workers which occur even within those firms which employ them. The first is a logical extension of the reluctance to employ coloured workers noted in Chapter Three. Having been constralned to employ coloured immigrants owing to the shortage of labour, some firms subsequently employ further coloured workers only when white workers cannot be obtained. For example, the Personnel Officer of Components Itd. said:

The coloured workers came in gradually, possibly where local people could not be obtained..... They were employed gradually and then only as necessary. It has always been a matter of keeping the labour force up to the amount required.

\footnotetext{
1. For reviews of these reports see Sheila Patterson (1963, Appendix IV) and Coloured Immigrants in Britain (Oxford University Press, 1960. Appendix)
} 
Another manager sald unequivocally:

Coloured workers are not employed unless they are urgently needed for specific jobs. We do not hire them unless absolutely necessary......We get a lot of coloured people coming for jobs and we have to turn them away. If a coloured man comes for a job, they (the Personnel Department staff) tell him that there is no vacancy, but if a white man came along within a few minutes they would take him on. Experience is needed and Jamaicans haven't got the experience.

(Personnel Manager, Ensign Spring Co.)

Had all the work carried out by the firm been of a highly skilled nature there would, perhaps, have been some justification for refusing coloured workers on the grounds that they did not possess the experience required. However, this was not the case in the Ensign Spring Co. Many of the jobs apparently required no skill whatsoever. Whilst walking round the factory, the writer noticed one job in particular, on which both white and coloured workers were employed, which consisted merely of feeding long strips of metal into a machine and then making sure that the small, shaped pieces which emerged at the other side fell clear of the machine and did not jam the mechanism. Other jobs on which coloured workers were employed included pushing a trolley load of raw materials round the machine operators to ensure that they always had enough metal to work with, or collecting the finished product in similar trolleys and wheeling them to the store. It is difficult to see how lack of experience could be a very great handicap in such jobs. 
The Personnel Manager of the above firm added that, although the Brit1sh workers accepted coloured labour, they (management) had to be careful not to have a preponderance of coloured workers in any one shop as thls might lead to trouble. As the flrm employed only 20 to 25 West Indians out of a total of 800 to 900 employees (1.e. about $2 \frac{1}{2} \%$ ), the danger of having a "preponderance" of coloured workers in any one shop was not very great. Similarly, in the Quality Steel Co., where the proportion of coloured workers was lese than one per cent, the Personnel offlcer stated that some of the white workers would resent the intrusion of the coloured immigrants if their numbers rose to fifty per cent of the labour force. However, concern over the ratio of white to coloured workers is quite common and in some cases perhaps a little more realistic. This concern has sometimes led to what is generally known as a "quota system".

The quota system may be derined as a method whereby the number of coloured workers employed by a flrm is kept at or below a given percentage of the total labour force. The intention In these cases is not to keep the number of coloured workers as low as possible, but to l1mit their numbers to below a certain maximum. The motivation is a bellef that the employment of a greater number of coloured workers would lead to unrest amongst the white employees and ultimately their refusing to work for the Pirm. At Drop Forgings Ltd., where about twelve per cent of the workers were coloured, the Personnel Manager sald:

The firm 18 at saturation point now with coloured 1abour. There is a danger that if any more were employed the white workers would possibly object... 
If over half the employees were coloured, the f1rm would get a name for belng a coloured works and we woulan't get white workers. This would not be a good thing because in general Jamalcans are not akilled enough for the highly skilled jobs, especially the highly skilled jobs requiring apprenticeship.

We are turning coloured workers away at the rate or 15 to 20 per day. We could employ another 300 coloured workers without difficulty if we wanted to. We get no end of enquiries from coloured employees to bring relations in, but we can't possibly sat1sfy all demands. We haven't enough jobs.

Similarly, in the Orange Graphite Co., where the proportion of coloured workers was again twelve per cent, the Personnel officer stated:

We must be careful not to overload a department with coloureds, You might have a department full of men who can do any labouring job, but no akilled man to operate the press. We need adaptability according to the state of the market and these people are not so adaptable.

In these I1rms, management was apparently $11 \mathrm{mlting}$ the number of coloured workers of their own accord. In one of the postal questionnalre flrms this-also appeared to be the case. The Personnel officer stated:

In the working groups relations are quite satisfactory, but in some workshops white workers start to express concern if the proportion of coloured people rises above 15\%. Apart from th1s minor factor, we have had no difficulty in employing coloured labour and we are continuing to recruit them. 
At Central Glass Works, however, the white workers in one department operated their own quota system and in another firm the percentage of coloured workers to be employed had been settled in an unofficial (gentlemen's) agreement between management and union. No further data was obtained on quota systems, but whether this was because they did not exist or because the flrms concerned preferred not to let it be known, It is impossible to say.

W1th respect to quota systems, Wood (1960) states:

Employers say that the quota system ensures a fair balance between white and coloured labour. It helps to scatter coloured workers throughout the industries of a town and prevents a firm getting the reputation of being 'a coloured' firm amongst 1 ts competitors. The system does cause a feeling of injustice amongst coloured workers who apply in vain for an advertised vacancy in a firm which has its full quota. And it is in a mild sense a colour bar.

Whilst one must sympathise with the coloured worikers who fail to obtain jobs because of a quota system, it should be pointed out that firms with a quota level of ten per cent are employing a very much inlgher proportion of coloured workers than there are coloured people in the country. The major limitation on the employment level of coloured workers is not the firms which Impose a quota system, but those which do not employ coloured workers at all. Were coloured workers evenly distributed throughout British industry, then the need for quota systems would disappear. Thus the fact that a firm 1mposes a quota 
level of, say, ten per cent is a sign that they are discriminating much less than the average firm rather than more. This is not to say that the writer wishes to recommend a ten per cent maximum for all firms: several firms in the present sample employed a much higher proportion and seemed quite satisfied with this situation. Nevertheless, it does seem unjust to unduly criticise firms which operate a quota system when other firms avold the whole question simply by "finding" that all coloured workers are insufficiently skilled to be employed. Some idea of the proportion of coloured workers employed by firms in the present sample can be gained from Figure 2. It will be seen that although most firms employed relatively few coloured workers, some flrms did employ well over the twelve per cent which the Personnel Manager of Drop Forgings Ltd. regarded as saturation point. One interesting point emerges, however. As can be seen in Figure 3, in most of the cases where a $h t$ h proportion of coloured workers were employed, they were Asian (Indian, Pakistani and Arab) workers rather than West Indian. This brings us to another way in which employment opportunities for certain, though not all, coloured workers might be restricted. There was a tendency for some firms to employ one coloured nationality at the expense of another. This was most marked in the case of West Indians and the broad category of Asian workers. Occasionally, a firm would, say, employ Indians at the expense of Pakistanis or vice versa, but, on the whole, firms would employ both if they employed Asians at als..1 
Figure 2: Proportion of Coloured Workers in the Total Labour Force (Interview and Questionnaire Surveys)

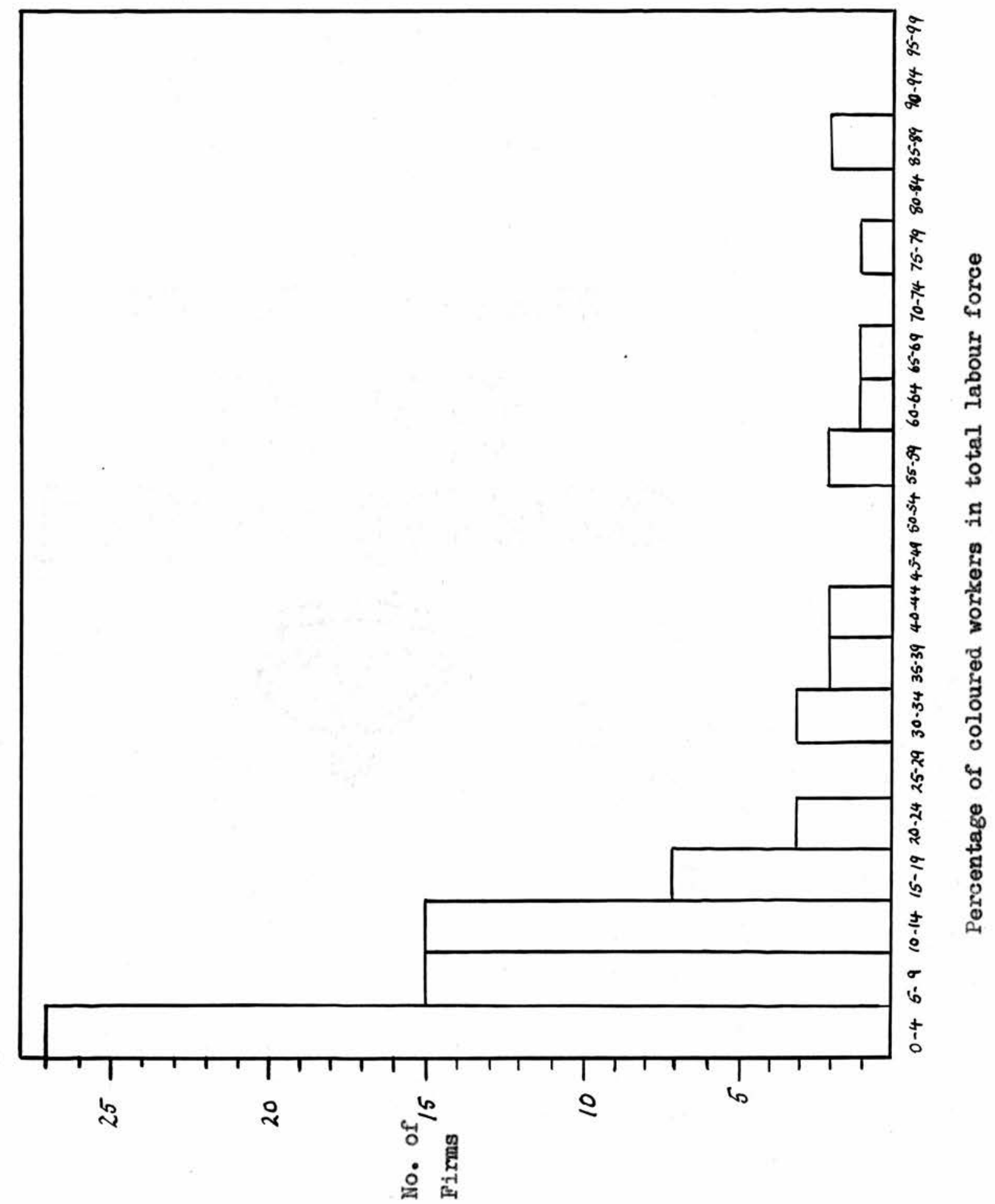


Figure 3: Proportion of West Indian and Asian Workers in the Total Labour Force (Interview and Questionnaire Surveys)

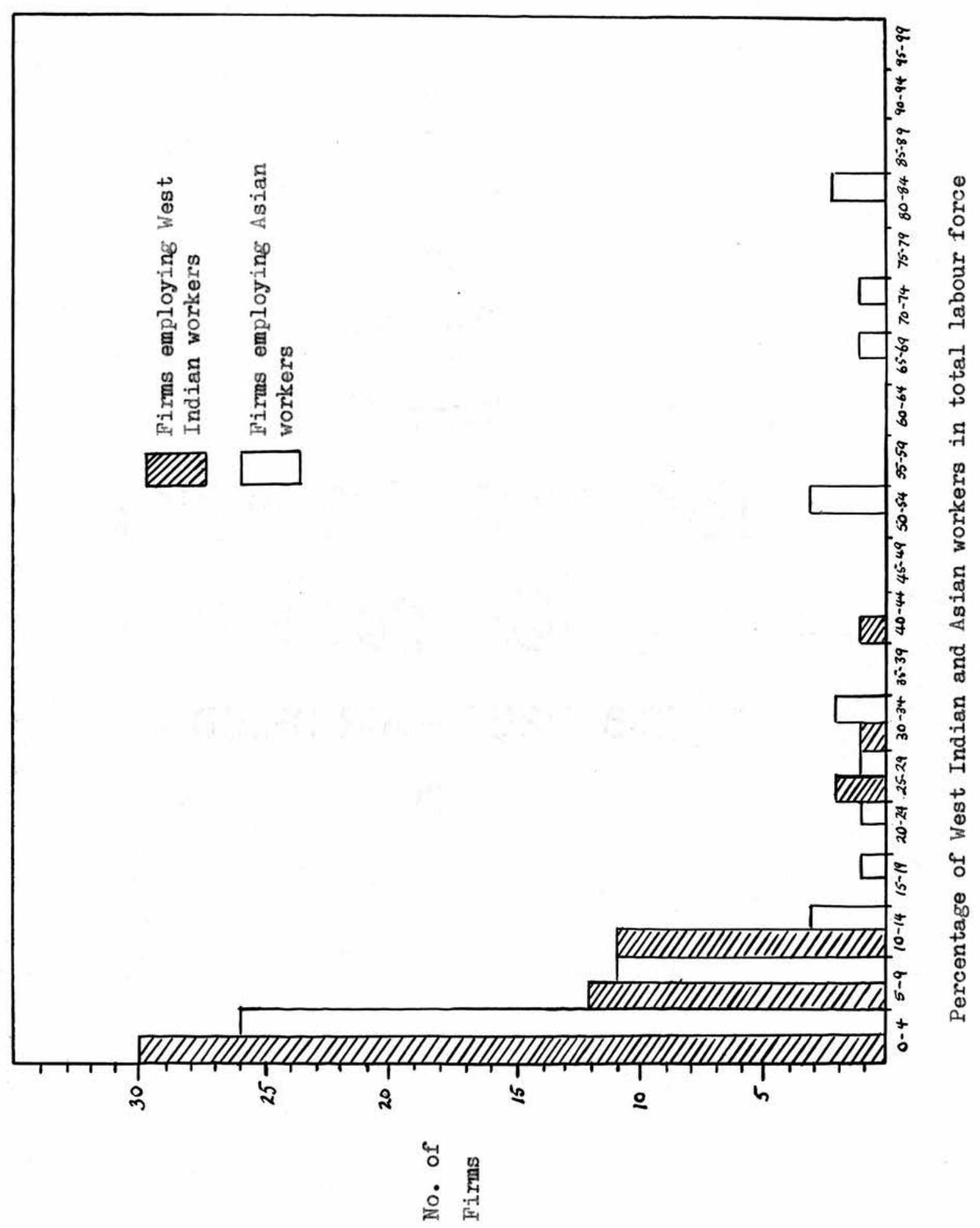


On the other hand, firms often employeô either Asian workers or West Indians rather than both groups. In the interview and questionnaire surveys, as can be seen in Table 13, there were 36 firms employing a preponderance of Aslan or of West Indian workers, compared with 29 with an appreciable proportion of both.

Table 13: Ratios of Weat Indian to Asian Workers (Interview and Questionnaire Surveys)

Firms with an Asibin to West Indian ratio of wore than $20: 1 \quad 19$

Firms with a West Indian to Asian ratio of more than $10: 1 \quad 17$

Mixed Firns

Total

Some indications of the reasons for this tendency were found in the interview surveys. In some cases, it represented a preference on the part of management for one nationality or group rather than another. Central Glass Works, ${ }^{2}$ the Ensign Spring Co., Drop Forgings Ltd.n the Trafford Iron and Steel Works and the Hamilton Engineering Co., for example, would only employ West Indians. Bradfield Foundry, Brierley Metal Works, Westwood Foundry, Muirhead Foundry and Omega Metals Itd., on the other hand, preferred Asian workers and employed only five or six West Indians at the most.

1. Firms with less than five coloured workers and others with inadequate employment statistics are omitted.

2. In this firm, the fact that the white employees were much less prepared to accept Aslan workers was another factor contributing to the employment of West Indians only. (See p. 203/4) 
In other firms (Steel Bars Ltd., Sterling Metal Co., Ridgeway Steel Co. and the Castle Iron Co.) the preponderance of coloured workers of one group had occurred largely by chance: Aslan workers had been the first to apply for jobs and the firm had contirued to employ them. The Personnel Manager of the Castle Iron Co. stated:

We don't have any preferences w1th regard to the different coloured nationalities. It's just that once you get one race in, you tend to get their pals and relations too.

In one case, however, although it had been a matter of chance which nationality had first been employed, continuing to employ only that nationality had been a deliberate policy decision on the part of the firm. Steel Bars Ltd, employed only Arab workers, not because they were preferred to other natlonalities, but because they were afrald that friction might result were another coloured group to be employed. The Works Director stated:

........1t worked out that way because we had these people (the Arabs) and we didn't want to mix them up. Because that was where we thought we might have trouble. If we were going to employ West Indians, we would employ West Indians and nothing else.

This question will be examined further in Chapter Elght.

A further possibility is that the preponderance of one coloured group rather than another may have resulted, in some cases, from a preference for certain types of jobs on the part of the coloured workers themselves. As will be seen in Chapter 
Seven, very fow of the Asian workers interviewed during the present research made any complaints about the nature of their work, whereas complaints about dust, dirt, heat and fumes were relatively common amongst the West Indians. One West Indian at Hamilton Engineering Co, who had previously worked in a foundry said of his present job:

It's not a lot or money, but it's not mucky, that's the best part. If I could get a job closer to (the c1ty), I wouldn't mind, but I don't want to go back to the foundry - it's a bit mucky.

Thus the fact that firms in the present sample with a high proportion of coloured immigrants tended to employ Asian workers may have resulted partly from the fact that they were largely foundries and others engaged in the dirtier type of work which the West Indlans, and of course, white workers, prefer to avoid if possible.

On the other hand, to suggest, as has sometimes been done, 1 that coloured Immigrants will refuse to do heavy or dirty work is hardiy justified. The evidence of the present research is that this is just the type of work which the coloured immigrants, including West Indians, have tended to obtain because of the limited alternatives open to them. Furthermore, the fact that unemployment amongst coloured workers averaged only about ten per cent during the period 1956-62, although they tend to find jobs more difficult to find than white workers, and the fact that there has been no hard core of coloured unemployed indicates that

1. For example, a writer in the correspondence columns of the Edinburgh Evening News (15th January, 1962) stated that he "could provide a long list of jobs which coloured immigrants will not look at because the work is heavy, dirty and hard." 
few, if any, coloured workers are remaining unemployed rather than take these jobs.

Whatever the reason for this tendency of some firms to employ a preponderance of certain coloured groups, however, it will be seen that employment opportunities for West Indian and Aslan workers were very similar in the firms studied during the present research. The number of flrms employing mainly Asians and the number employing mainiy west Indians are approximately the same (Table 13), and the tendency for sone firms to employ a high proportion of Astan worixers is balanced by the larger number of firms employing West Indians where the proportion of coloured workers is smaller (Figure 3). On the other hand, it would be inadvisable to generalise too widely on the basis of this data in view of the relatively small number of firms involved and the fact that the number of coloured workers in the areas concerned is not known with any degree of accuracy. We shall, therefore, rely on other sources of information to provide a general picture of employment levels amongst the different coloured groups.

Writing in 1960, Wood claimed, that: "Almost certainly the (unemployment) rate is higher amongst Injians and Pakistanis than amongst West Indians." Similariy, Sheila Patterson states that the Indians and Pakistanis were the chief groups to suffer when coloured unemployment doubled from about 7,500 in Autumn 1957 to 15,000 in March 1958, West Inaian unemployment rising only from 4,500 to 6,000 during this period. On the other hand, the fleld research carried out in 1961 by the Economist 
Intelligence Unit found the highest rate of unemployment (nine per cent) amongst West Indians; the figures for Indians and Pakistanis being five per cent and seven per cent respectively. However, the fact that only three per cent of the Pakistanis were in unskilled jobs strongly suggests that the sample was not representative in their case.

Based on official statistics, probably the most conclusive evidence on the unemployment rate of the different coloured groups is that of Davison (1964) who calculates the average unemployment rate amongst West Indians, Indians and Pakistanis from August 1961 to February 1963 to be 9.5 per cent, 5.7 per cent and 15.6 per cent, respectively. Thus it would appear that unemployment is most acute amongst the Pakistanis, but less acute amongst the Indians than the West Indians.

It is therefore impossible to generalise, as Wood and Patterson do, about unemployment amongst Indians and Pakistanis as a group as far as the country as a whole is concerned. However, it seems likely that one of the main causes of the high rate of unemployment amongst Pakistanis is their geographical location. They tend to be more numerous in the North of Fngland where unemployment rates in general tend to be higher than the rest of the country. In Bradford, for instance, where Pakistanis constituted nearly two-thirds of the total unemployed in the first half of 1962, there are relatively few Indians and West Indians. Thus the effect of their geographical location would go some way towards explaining why Pak1stanis have a higher rate of unemployment than Indians, when firms tend to accept both Indians 
and Pakistanis if they employ Aslans at all, and often do not distinguish between the two groups for employment purposes. 1

Finally, employment opportunities for coloured workers are sometimes restricted because certain departments or sections of firms refuse to accept them, although management as a whole is prepared to employ them. In the Ridgeway Steel Co., it was left to the departmental managers to decide whether they would employ coloured workers or not. Some employed Pakistanis, some employed no coloured workers whatsoever, none employed West Indians and some employed Pakistanis but refused to accept Irish. At Polton Rolling Mills, the Labour officer claimed that the preponderance of Asian workers employed by the firm was not an indication of a preference for these workers on the part of management: it was just that these workers were the ones who had applied for jobs. Whilst this may have been an expression of official policy, conflicting evidence was found elsewhere. The Manager of one of the departments stated:

I wouldn't have a West Indian or a Somal1: they are bone idle and arrogant. The Personnel Manager sent a Somall up here for a job and I told him (the Somal1) that there wasn't one and sent him away. I just wasn't having him.

1. Davison states that the high rate of unemployment amongst Pakistanis "may be due in part to their different geographical location...... but is far more likely to be due to the language difficulties they experience. The fact that an immigrant cannot speak English, complicated by religious and cultural differences, (e.g., in diet, clothes and customs) tends to inhibit employers from offering employment unless they are desperately short of labour." However, this explanation fails to account for the fact that Indians who also have language difficulties, different customs and different religions, have a lower level of unemployment than West Indians who do not. 
In other firms, coloured workers were not accepted in certain departments because of resistance from the white workers.

We had consultation with the Shop Stewards Organisation. There was some reluctance, but no, great difficulty. We still have some departments that won't have them.

(Personnel Manager, Major Castings Itd.)

We sounded out the white workers before we employed coloured labour. The odd element of the hot workers resented the ldea so they weren't introduced there.

(Personnel Manager, Pentland Alloys Ltd.)

We had no serious difficulties when coloured workers were first employed. Certain departments refused them for a time: some still do - certain skilled trades such as building. We had great difficulty getting them accepted in the machine shop, but by and large they have been accepted, except in the building and electrical trades.

(Personnel Manager, Soverelgn Steel Works)

Finally, at Central Glass Works, not only did the white workers play an important part in deciding where the coloured workers were to be employed and in what numbers, but they also had considerable influence in determining the nationality and sex of the coloured workers to be employed. The Personnel Manager stated that in 1954, when it was found necessary to employ coloured workers, the white workers were consulted by the management. He claimed that the white workers were prejudiced 
against Asian workers because they were afraid of disease being spread and against female coloured workers. As a result, only West Indians had been employed and of these only one was a woman.

The coloured workers in this firm were employed mainly in unskilled jobs on the production side. Most of the workers employed on washing scrap glass (which is used for fusing purposes) were West Indlan, the remainder being mainly Poles. This job is so distasteful, according to the Personnel Manager, that the British workers tend to avoid 1t. There was also a preponderance of coloured workers in one of the production shops where there is a repetitive redundancy pattern. "Men tend to get laid off," the Personnel Manager said, "and the local type of workman won't stand for 1t, so more coloured workers are employed." In the other production department where there was no redundancy pattern, there were fewer coloured workers because their numbers were limited by the white workers who had their own quota system. No coloured workers were employed in the skilled shops and there was also none in the maintenance department because the white workers would not accept them. It will be apparent that, in both Central Glass Works and the Sovereign Steel Works, the resistance of certain departments to the employment of coloured workers limited not only the number, but also the "quality" of jobs avallable, in that the white workers concerned tended to be in the more skilled and desirable trades. Before turning to the question of employment levels, however, we will first examine the question 
of redundancy.

(c) Redundancy and the Coloured Worker

It is obvious that unemployment amongst coloured workers w1ll be high, not only if they find jobs more difficult to obtain, but also if they lose them more easily in times of unemployment. Richmond (1961) states that during the 'thirties, coloured seamen became resigned to the fact that they would be 'last to be hired and first to be fired'. This does not appear to have been the case in post-war industry. Wood states:

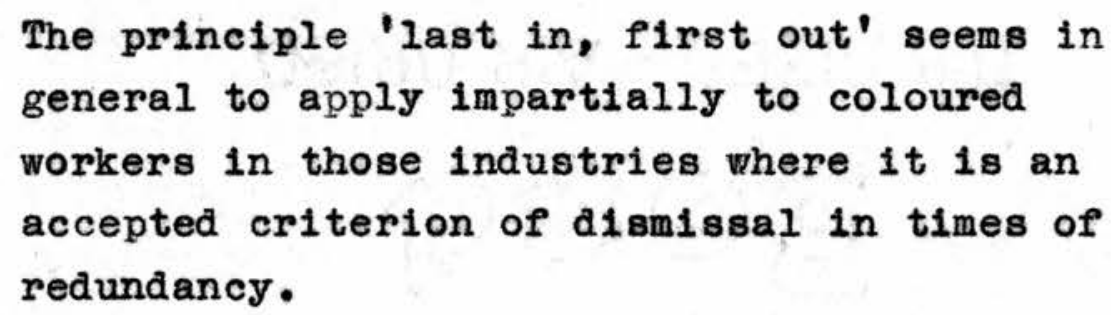

Although limited data were obtained on redundancy procedures in the present research, the general impression gained during the Interview survey was that, with one major exception, the 'last in, first out' policy was largely accepted.

How then are we to account for the fact that unemployment tends to be particularly acute amongst coloured workers during times of redundancy? Wood states that some coloured workers suspect that they are not always treated fairly with respect to redundancy. Whilst this may be so in some cases, three other plausible explanations can be advanced.

Pirstly, some of the unemployed coloured workers during recessions have undoubtedly been new arrivals who had not yet obtained employment in Britain and found it more difficult than usual to do so during these times. 
Secondly, coloured workers are relative newcomers to British industry. In many cases, therefore, and especially if only recently arrived in the country, they have shorter service records than British workers and, quite legitimately, will be the first to be dismissed when redundancy occurs. The Labour Officer of Edge Tools stated, for example:

The firm operates on a first in, last out basis, but the coloured workers are genuinely last in. Thirty employees became redundant recently mainly Pakistanis. They were all given a week's notice and a week's compensation. 1

Thirdly, there tends to be a higher proportion of coloured workers in unskilled jobs than white workers. As unskilled labourers are the least indispensable members of a firm's labour force, they are likely to be made redundant in times of falling production. Thus, the fact that large numbers of coloured workers are in unskilled jobs may be due to discrimination, but the fact that a high proportion of them, as labourers, become redundant may not be the immediate result of any unequal treatment.

Paradoxically, the one firm in the interview survey where discriminatory treatment with respect to redundancy was encountered, provides a good illustration of this point. The Personnel Manager of the Castle Iron Co. stated that when

1. A foreman at the same firm stated that, during a fall off in production, the manager had kept coloured workers on sweeping floors and cleaning windows just to avoid having to make them redundant. 
coloured workers had first been employed, the white employees had insisted that they would be the first to go should there be any redundancy. An understanding ("a sort of gentlemen's agreement") to this effect was reached between management and the union. This agreement was still in force at the time of the interview and had been implemented on one or two occasions. On two occasions, however, semi-skilled coloured workers had been retained and white "floaters" 1 had been "dispensed with". "It does cost money to train a man," the Personnel Manager said, "so it would be uneconomic to dismiss a coloured man once he had been trained."

\section{The Occupational Level of Coloured Workers}

We have noted that, when first employed, coloured workers tended to obtain the jobs whlch the white worker found too arduous, distasteful or unrewarding. In the firms visited during the interview survey, this was often still the case at the time the research was carried out. For example:

The kinds of jobs coloured workers do are the knocking out and quenching of castings. Neither job is relished by the white worker. Knocking out is a sledge-hammer job. It's outside work, so it's cold in winter and in summer the bits of sand stick to you when you're sweating.

(General Manager, Stainless Steel Ltd.)

1. Workers who only take jobs for short periods of time. 
Coloured workers are employed mainly on the lower-paid repetitive and semi-repetitive jobs such as electrode cleaning. This is the sort of job that if a white man took it, he doesn't really want a job at all. The West Indians are mainly employed on scrap-crushing, a sledge-hammer job. They also do the loading and unloading of pitch. The highest job done by any coloured worker is fork-11ft truck operator.

(Personnel Officer, Grange Graphite Co.)

In four of the interview survey firms coloured workers were employed only in unskilled jobs. ${ }^{1}$ In another ten firms, the majority of coloured workers were in unskilled occupations, but there were also one or two who had obtained positions such as crane-driver, slinger, fettler, driver, fork-lift truck operator, and in one case skilled positions on the rolling teams. ${ }^{2}$

Amongst the remaining seventeen firms, coloured workers were employed in both unskilled and semi-skilled jobs in appreciable numbers in nine cases, ${ }^{3}$ and employed in some skilled jobs as well as unskilled and semi-skilled work in a further seven cases. 4 In the remaining firm, insufficient data were obtained to stipulate the occupational level of the coloured workers employed. 5

1. Pirms $5,21,26,30$,
2. Firms $8,11,15,16,17,18,22,23,25,27$.
3. Firms 1, 10, 13, 19, 20, 24, 28, 29, 31.
4. Firms 2, 3, 6, 7, 9, 12, 14.
5. Pirm 4.


Coloured workers usually obtained semi-skilled jobs (and often skilled fobs), not by being employed on them when they first joined the firm, but by being trained and promoted from lower grades of work within the organisation. In the Hamilton Fngineering Co., for example, some fifty per cent of the West Indian workers, initially employed as unskilled labourers, had progressed to semi-skilled jobs such as slinger, crane-driver and machine operator in this way. In another firm, Edge Tools Ltd., the steps by which coloured workers eventually obtained semi-skilled jobs was described as follows:

The first coloured workers we employed were Indians and Pakistanis. They were put on labouring jobs because of their lack of capabilities. It was thought that they were not capable of fast piece work on skilled jobs, so we put the coloured workers on labouring jobs and moved up the people they had displaced. Eventually, however, they had to be put on the better jobs because there weren't even enough white workers for these..... The firm's policy has been to put the coloured workers on the easiest and most menial tasks and then to select those who shaped well for the better jobs.

A remarkably similar policy was found in Pentland Alloys Ltd. Here the coloured workers (West Indians on this occasion) were flrst employed as machine shop labourers. Later, however, some of them were promoted to such jobs as grinder, crane-driver and slinger. According to the Personnel Manager:

We have never taken a man on as a slinger or a cranedriver. We have taken them on as a labourer and they 
have fitted in and we have liked them, so they have been promoted.

The jobs of slinger and crane-driver were specially selected for the coloured workers when the question of promotion arose, because they were not jobs which would lead to a position of authority. Although of a higher grade than the ordinary labouring job, they were still in effect "dead-end", because they did not lead any further. The Personnel Manager said:

We have made it a policy never to employ a coloured man in a position, such as part of a team in hot rolling, where in the course of events he would rise to a position where he would have to give orders to a white man.

It w1ll be noted that in the list of semi-skilled occupations on which coloured people were employed given above, most of them were the same type of "differentiated" job, and perhaps for the same reason.

As noted in the previous section, Pentland Alloys Itd. employed coloured workers not out of necessity but as a matter of policy. It would appear that the firm wished to be altruistic, but did not wish to take any risks whilst doing so. Only West Indians were employed because of the language difficulties which arise with other coloured nationalities, and even then only in limited numbers ( 35 out of 4000 , or less than 1\%) and in limited occupations because they were afraid that trouble might arise should a coloured worker rise to a position of authority over a white worker. To what extent was this fear justified? As will be seen in Chapter Eight, there is a tendency for 
resistance to coloured workers on the part of white employees, to be greater the higher the grade of job the coloured worker obtains, the greatest resistance arising in the case of supervisory posts. Nevertheless, coloured workers were employed in jobs of a higher status than white workers in some of the interview survey firms. Whilst walking round one of the departments in Precision Bngineers Ltd., the writer noted two identical jobs, one with a coloured worker assisting a skilled white worker and the other with a white worker assisting a skilled coloured worker. In another firm, the Sterling Metal Co., the Personnel Manager stated that there had been some trouble over skilled men. On one job, coloured workers were assisting white workers, and one or two were so good that management had wanted to up-grade them. However, the union had objected and the plan was dropped. Yet, on another job in the same shop, (bar reeling), a coloured worker had been made a skilled man and was assisted by white workers. The white workers wanted to work with him because his rate of production was so high. At Drop Forgings Ltd,, a similar example was given. The firm employed 55 West Indlans, about 48 of whom were employed on the forges in one capacity or another. The majority of them were on unsililed jobs such as sweeping up, general labourer, Pitter's mate, oller, and so on. Others, however, had higher status jobs: one was a truck driver, another a weigh clerk, two were welders (a skilled job, the men having been trained in Jamaica), one was a tool setter (also a skilled job), and about half a dozen were stampers. The stamper 1s the only skilled man 
In a four man team, and on a short trip round the factory the writer observed a number of such teams working. Several consisted of a white stamper assisted by West Indian labourers, one team was entirely West Indian, and one consisted of a West Indian stamper assisted by three white labourers. With respect to the latter, the Personnel Manager suggested that jealousy might arise because the West Indian earned more money than his white assistants, but as the earnings of the team depended upon the skill of the stamper, who controlled the rate of production, the men liked to work with a good stamper irrespective of skin colour. Other firms in the interview survey had employed coloured workers on precisely the job which Pentland Alloys Itd. had thought Inadvisable, that is as part of a rolling team. Such a team, or set as it is called, usually has six or seven members, and forms a hierarchy from the roller at the top to the spare man at the bottom. Under normal conditions the lowest member of the set is a boy who is being trained, and who, as his training proceeds and as vacancles occur, works his way up the hierarchy. It was on these fobs that coloured workers had been employed in the Qual1ty Steel Co., but here they apparently had not progressed very far. At Soverelgn Steel Works, on the other hand, the coloured workers had risen as far as third hand melter, and the firm had obtained acceptance from the men that coloured workers would be piomoted higher than third hand should the situation arise. The Personnel Manager added, however, that it was doubtful whether this would happen in the near future because of lack of skill. Similarly, in Steel Bars Ltd., coloured workers were employed 
as part of rolling sets and had risen to the more senior positions on the "back side", 1 the lower grade jobs being done by white youths. Again, however, the Works Director stated:

Mind you, we would never put them forward to be a roller. They would have to converse daily on that job and they could not do this yet. We feel that there is a level beyond which they can't go.

Here, perhaps, is the crux of the matter. At Pentland Alloys, only West Indlans were employed whereas the coloured workers on the sets in the above flrm were all Asian (mainly Arabs, in fact). Thus there was, in effect, little danger that they would rise to the most senior positions because they lacked the necessary language and literacy qualifications. Were West Indians to be employed on this job, however, the coloured worker might eventually rise to a position where he could claim promotion to roller as his right, having gone through the intermediate stages in the hierarchy. This might lead to objectionsfrom the white workers as management in Pentland Alloys feared. Grunted that the white workers in the Sovereign Steel Works had consented to the promotion of coloured workers above third hand level, but they knew as well as management that this was unlikely to happen in the near future.

1. The billet of steel is passed through the rollers a number of times until it is of the required size and shape. Thus once the billet has passed through the rollers from the "front side" to the "back side" it must be returned again for the next run through. Positions on the "back side", though on the promotion ladder, are of inferior status to those on the front and 1 t was on these jobs that coloured workers were employed in this firm. 
Apart from the above examples, it was rare for coloured workers to obtain jobs directly above white workers in the job hierarchy. Where coloured workers did obtain semi-skilled and skilled jobs, they tended to be of the "differentiated" type. Whilst the jobs were of higher status than others in the factories concerned, they did not entail authority over other workers. In addition, there was a tendency for white workers not to do jobs at a lower status level than coloured workers irrespective of whether the jobs were differentiated. In other words, whatever level the coloured workers reached, there was a tendency for coloured workers to do the jobs below that rather than white workers. Thus, with the exception of Drop Forgings Ltd., the firms where coloured workers were employed on skilled jobs in significant numbers (Bradfleld Foundry, Brierley Metal Works, Westwood Foundry, Mulrhead Foundry and Omega Metals), were also those in whlch the largest numbers of coloured workers were employed. In these firms, most of the white workers were in the higher status jobs, whilst the coloured workers tended to do the majority of the lower status work in addition to some of the higher status jobs. Thus, there tended to be a mixture of white and coloured workers at the top of the job hierarchy with the lower end of the scale consisting mainly of coloured workers. The fact that four of the above firms are foundries may also be of significance. This industry was particularly hard hit by the post-war labour shortage, and, in the Midlands at least, this shortage seems to have extended to the skilled as well as the unskilled jobs. A foreman at Bradfield Foundry claimed that 
during the 'thirties working at the foundry had been regarded as a very good job. "It was almost impossible to get a job here; you practically had to wait for someone to die before you could get in." In the post-war years, foundry work became less popular and labour became increasingly difficult to obtain. In the early 'flfties, advertisements such as "moulder wanted prepared to train willing man" were common. According to the foreman, management would bring in a new man, supposedly to assist a moulder, but in actual fact to learn the trade from him. In 1953, one naturalised Itallan (an ex prisoner-of-war) and one Pakistanl were employed. By 1962 forelgn workers constituted some $75 \%$ of the total labour force. The remaining British workers, with few exceptions, were on the staff and in the higher skilled trades. Though not a few coloured workers were also in skilled jobs, none of them were on the staff.

In Omega Metals Ltd, on the other hand, a coloured worker had been promoted to a supervisory post. This firm, a small engineering concern, also employed a high proportion of coloured workers. Apart fron the staff, there were eleven British workers, one West Irian and fifty-one Pakistanis. The British workers were again mainly in the higher status jobs; they consisted of two shot blasters, a fitter, a welder, an assembler, a fork-lift truck operator, and five drivers. The one West Indian was a fitter's mate, and the Pakistanis were mainly concentrated in the lower status jobs. All unskilled work, in fact, was carried out by Pakistanis. However, three were shot blasters, several were painters, and one was a chargehand. Nevertheless, none of the 
coloured workers in the higher status jobs had any authority over the British workers. Where the skilled worker had an assistant, the assistant was also coloured, and the authority of the chargehand extended only to the Pakistanis, and not to the white workers or the West Indian.

In the only one other firm in the interview surveys in which a coloured worker had obtained a supervisory post, the position was remarkably similar. At Sterling Metal Co., a Somali had been made chargehand "over his own people" in the boller house. Thus in both cases the job of chargehand was, in effect, a "differentiated" one, in that it was part of a separate status hierarchy in which there were only coloured workers. The men concerned were colourea chargehands rather than chargehands who happened to be coloured. This question w11l be examined further in Chapter Six.

We now turn to the occupation level of coloured workers in the postal questionnaire firms. It was possible to obtain adequate data on the level at which workers, both white and coloured, were employed in thirty-eight cases. These data are presented in Table $14 .^{1}$

1. One case, a bus company, was omitted because it was thought to be atypical:-

a) Although large employers of coloured workers, there were only two bus companies in the area under study and therefore to Include one of them in such a small sample would produce a disproportionate effect on the results.

b) We are mainly concerned with industry and the occupational structure of a bus company differs from that of an ordinary industrial concern in certain respects: (1) a very high percentage of the employees are in skilled and semi-skilled jobs, (2) there is an equal proportion of skilled to semi-skilled jobs (one driver to a conductor), (3) the main category of skilled job (driver) does not require apprenticeship training. 
Table 14 : Occupational Level of British, Coloured and White Inimigrant Workers (Questionnaire survey)

\begin{tabular}{|l|c|c|c|c|}
\hline \hline & \% Skilled & Seiri-skilled & \% Unskilled & No. \\
\cline { 2 - 5 } British Workers & 24 & 66 & 10 & 50191 \\
White Iraidrants & 9 & 70 & 21 & 214 \\
Coloured Inami@rants & 2 & 40 & 58 & 2307 \\
West Indian & 2 & 40 & 58 & 1356 \\
Pakistani & 1 & 39 & 60 & 784 \\
Indian & 11 & 39 & 50 & 127 \\
Arab & 9 & 65 & 26 & 23 \\
African & 12 & 70 & 18 & 17 \\
\hline
\end{tabular}

The same data are presented diagrammatically in Figures 4 and 5 . It will be seen in Figure 4 that the occupational level of coloured workers was considerably lower than that of British workers, with that of foreign white workers, in general, falling between the two.

In Figure 5, the occupational levels of the different coloured groups are presented separately. It would be of considerable interest to compare these data with the actual skill level of the coloured workers concerned. However, this involves several difficulties. It is impossible to obtain adequate data on this question from a questionnaire directed to management. Any information from this source would have to be treated as bellefs rather than statements of fact and is, in fact, exanined as such in Chapters Five and Six. We must therefore rely on data 
Figure 4: Occupational Distribution of British, Coloured and White Immigrant Workers (Questionnaire Survey)

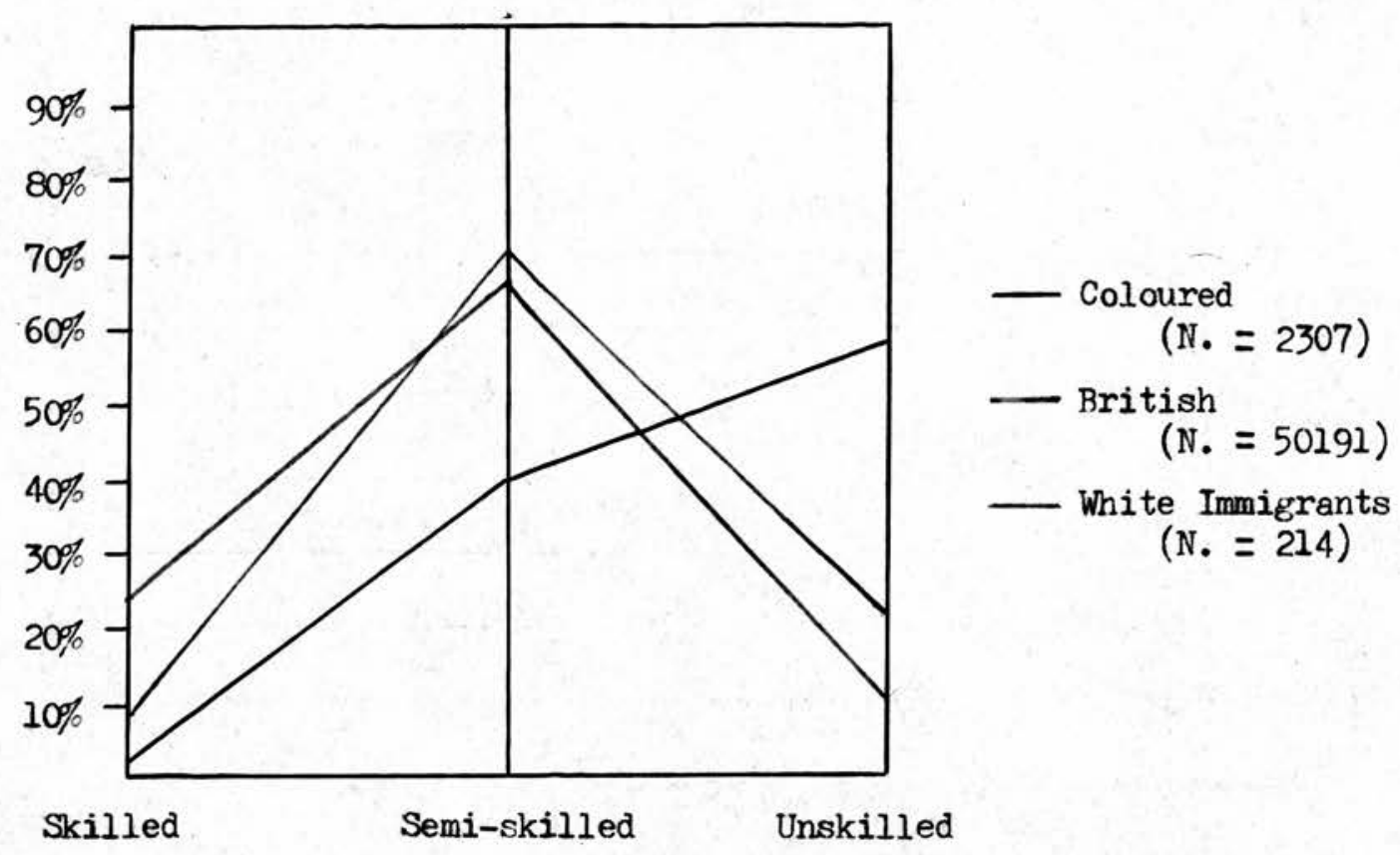

Figure 5 : Occupational Distribution of Coloured Workers (Questionna1re Survey)

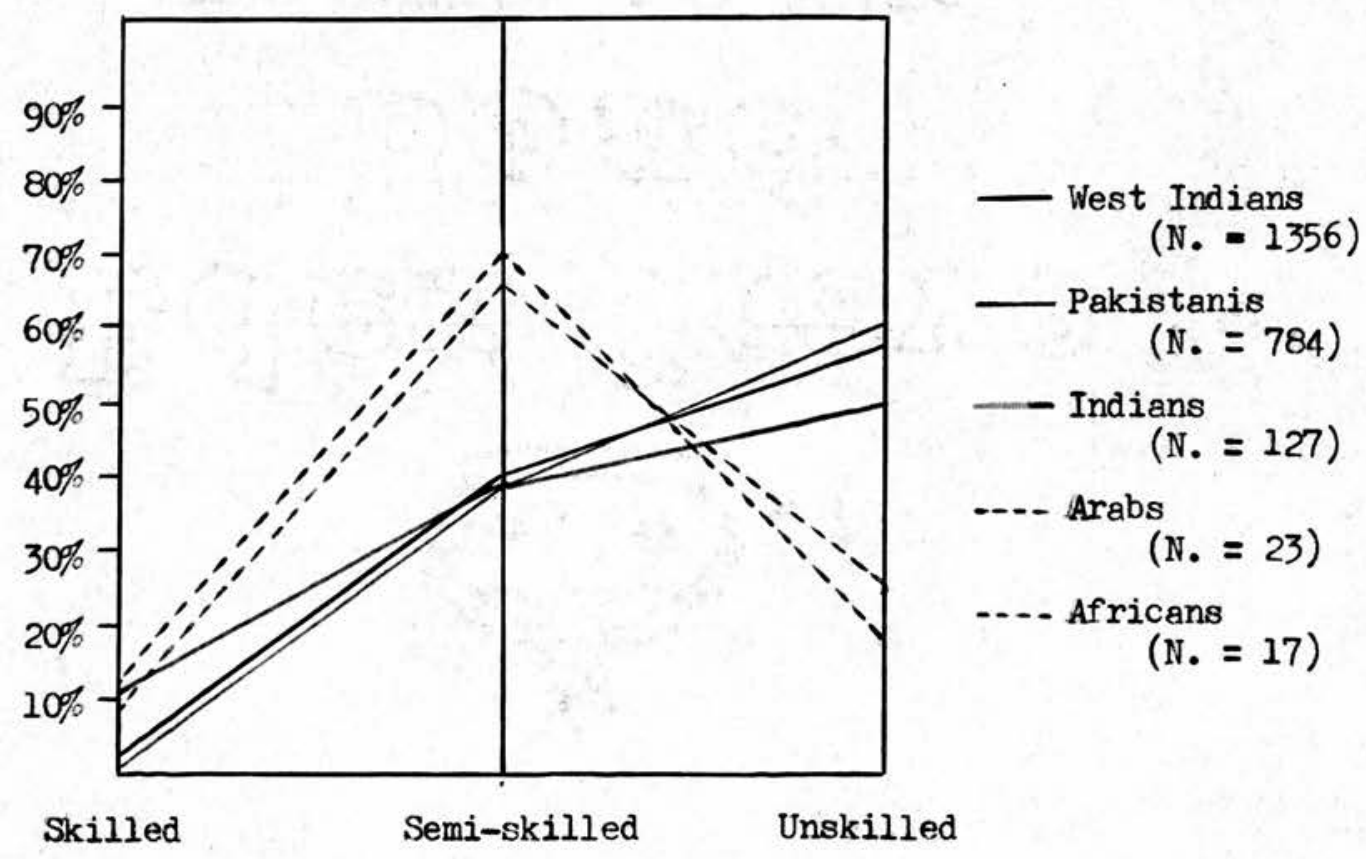


from the literature. But this has two main drawbacks: firstly, it is not very reliable being scarce in the case of Asian workers and contradictory in the case of West Indiars: and secondly, we do not know how representative these data are of the coloured workers employed in the firms in the present sample. Nevertheless, such a comparison may be of some use providing the limitations of the data are kept in mind.

We suggested in Chapter Three that the estimate of $13 \%$ skilled, 22\% semi-skilled and $65 \%$ unskilled given in the Civil Service Argus probably represents the nost realistic assessment of the skill level of West Indian manual workers. In Figure 6, these data are compared with the occupational distribution of West Indians in the present sample of firms. It will be seen that although there are fewer West Indians than would be expected

Figure 6 : Estimated Skill Level of West Indian Immigrants Compared with Occupational Level

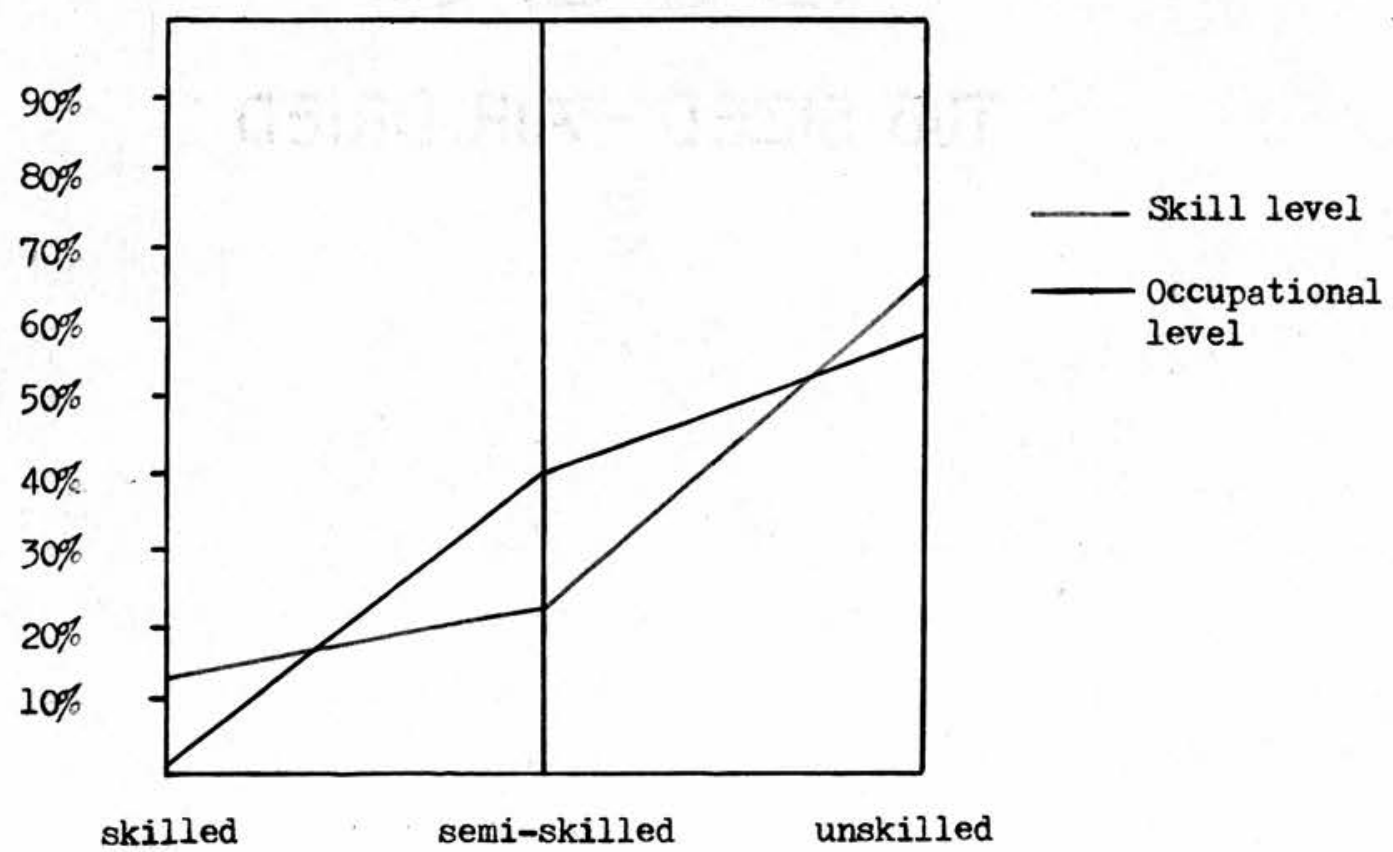


In the skilled jobs and unskilled jobs, there are more in the sem1-skilled jobs. This would suggest that resistance to coloured workers is greater in the more skilled jobs, which is consistant with other data in the present research. On the other hand, it would appear that some unskilled coloured workers have been accepted and trained for semi-skilled posts, and several examples of this were found in the interview survey. Thus, on balance, it would appear that the West Indians in the present sample of firms have expertenced very little occupational down-grading. However, two points must be noted. Firstly, a large number of West Indian migrants are "white collar" and not manual workers. Because of the greater resistance to coloured workers in "white collar" jobs, many of these may have had no alternative but to take manual jobs. Although such workers may technically be unskilled as far as manual work is concerned, to be placed in the position of having to accept such work undoubteôly represents down-grading. Secondly, if the statements of West Indians concerning their own skill level (which are to be found in several. studies reported in Chapter Three) are accepted as representing their level of aspiration, then it is apparent that the occupational level attained ialls below that expected and will probably be perceived as down-grading.

On the other hand, if the estimates of Desal, Alavi and Kathleen Hunter are accepted as representing the skill levels of Indian and Pakistani immigrants, then Asian workers have, in general, achieved considerable occupational up-grading. On this basis, one would expect Asian workers to have a considerably 
higher level of job satisfaction although their occupational level is, in fact, little different from that of the West Indians. As will be seen in Chapter Seven, when we come to examine the question of job satisfaction, this was actually the case amongst the Aslan and West Indian workers interviewed during the present research.

The lack of correspondence between the skill and occupational levels of the different coloured groups is perhaps the most surprising thing to emerge from Figure 5. The skill levels of Pakistani, Indian, Arab and African groups are probably lower, and in the case of the Pakistanis much lower, than that of the West Indians. However, the occupational level of the Pakistanis is only fractionally lower than that of the West Indians and in the case of the Indians, Arabs and Africans is actually higher. In view of the small sample of Arabs and Africans and the limlted data concerning their skill levels, it would be unwise to place too much confidence in the findings. Nevertheless, this st1ll leaves us with the problem of explaining the disparity in the case of West Indians, Indians and Pakistanis.

Part of the answer may lie in the conditions under which coloured workers tend to gain employment. Because firms prefer not to employ coloured workers, their occupational level as a whole tends to vary not so much with their skill level but with the number and type of vacancies which cannot be filled by white workers. If white workers can be obtained for sk1lled jobs, then coloured workers tend not to be employed in them whether they are skilled or not. On the other hand, if white workers, 
whether already skilled or capable of being trained, cannot be obtained for semi-skilled and in some cases skilled jobs, then coloured workers will be employed and if necessary trained up to the requisite standard. As we have already noted, however, coloured workers tend to be employed at first on unskilled jobs, and skill is only one of the factors which determine managerial preferences when deciding which coloured group should be employed as labourers. Thus whether a coloured worker obtains a skilled job or not may aepend more upon whether he happens to be employed in a firm whore skilled or semi-skilled workers are desperately needed than upon his own skill level.

A further interesting point arises from Figure 5. It will be seen that the occupational level of the different coloured groups tends to be inversely related to the size of the sample. It may be, therefore, that the fewer coloured workers there are in a group, the greater their opportunities for obtaining the more skilled jobs. If, as we have suggested, there is a tendency for firms to employ one group of coloured workers rather than another, it follows that there is a relatively stable number of jobs avallable to each national group. As a result, coloured workers will tend to be in competition not so much with coloured iminigrants in general, but rather with other members of their own group. Thus, the fewer immigrants there are in the group, the smaller the competition for the better jobs and the greater tieir opportunities for obtaining them. On the basis of the present evidence, this explanation nust be treated as no more than a tentative hypothesis, but it is perhaps worthy 
of further research.

4. Summary and Conclusions

In this Chapter, we concluded that employment levels amongst coloured workers were, in general, lower than amongst white workers. Amongst the different coloured groups, employment levels appear to be lowest in the case of Pakistanis, but higher In the case of Indians than West Indians, During times of recession, unemployment amongst coloured workers has tended to rise more rapidiy than amongst white workers and to go down again more slowly when trade recovers. However, there has been no hard core of coloured unemployed suggesting that coloured workers tend to have longer periods between jobs rather than to be permanently unemployed. The occupation levels of coloured workers in general were found to be lower than those of native British and forelgn white workers, but there was remarkably little difference between the occupational levels of the three major coloured groups.

What then of the future? As far as occupational levels are concerned, it will be apparent that coloured workers have made some progress towards industrial integration during the time span covered by the present research. When first employed, coloured workers were given unskilled jobs in the main, but many were later given semi-skilled and in some cases skilled jobs. However, this progress seems largely to have been dependent on a shortage of white workers in these trades and there is a limit to the number of skilled jobs which can be obtained by workers 
without apprenticeship training, or even with such training if white workers are always given first choice.

To a large extent, therefore, the future integration of coloured workers depends upon coloured children obtaining apprenticeships and gaining acceptance into the skilled trades. On this subject, Sheila Patterson states:

A minority of exceptional individual migrants have begun to move up from the bottom of the industrial ladder and to undermine the British workers' notion of coloured workers as Lascars, coolies and cane cutters in far away lands. Such progress 18 limited by the low industrial capacity of the majority of to-day's migrants. It could be speeded up when the locally educated second generation enter the labour market. The latter will no longer be strangers, but they w1ll still have to strive against the 'class' notion that coloured workers are on the whole suitable only for unskilled and sem1-skilled work, just as their parents have had to combat the 'stranger' notion to win acceptance as a permanent part of the local labour force.

Relatively little data was obtained on occupational opportunities for coloured children during the present research as the emphasis was mainly upon the employment of adult migrants. Such information as there is, however, does not paint a very optimistic picture. The Personnel Manager of Ensign pring Co. stated that trouble might arise soon because of coloures school leavers; there was still resistance to employing coloured workers In skilled jobs and one couldn't employ school leavers as labourers. In the Regal Manufacturing Co. two Indian youths 
had been employed, although the firm did not usually employ Asian workers because of the language difficulties involved. The Personnel Manager stated that language difficulties did not arise in the case of the youths because they had been to school in this country, but it was difficult to find jobs for such people; they were too old for the type of jobs usually given to school leavers and not old enough for labouring. Finally, at Tool Steel Ltd. the Personnel Manager stated:

The time is coming when, if you employed a young lad from school and he learned his trade in a particular shop, the chances are they would accept him as a skilled man. But if we employed a coloured man in a skilled job who had been trained at another firm and they hadn't had a chance to get used to him, then he would almost certainly be rejected.

Whether these managers are correct in their assumptions or not is to some extent 1rrelevant: what is important is that they represent beliefs of the managers concerned, and as long as 1t is belleved that difficulties might arise, then firms are likely to be reluctant to employ coloured school leavers. In the latter case, the respondent stated that the chances were that a coloured school leaver would be accepted. However, if there is no desperate shortage of apprentices, as there was of unskilled labourers, then it is questionable whether firms will be willing to take this chance.

At the same time, lack of employment in skilled occupations may in the future serlously limit the number of jobs available to coloured workers. In one of the interview survey firms, 
Blackford Rolling Mills, coloured workers had originally been employed in the hot-rolling mills because of the shortage of unskilled labourers. Since then, however, the hot-mill had been shut down and the firm had turned entirely to mechanised cold rolling which required malnly skilled workers. Some of the skilled workers had been transferred from hot rolling to cold rolling, but all the coloured workers had become redundant, and at the time the present research was carried out were only employed as casual labour during the annual "shut-down". Similarly, at Westwood Foundry, there was a possibility that the firm's requirements for coloured workers would be reduced by mechanisation. A new, fully mechanised, moulding plant was being bullt. According to the Labour Officer, the number of workers needed would probably remain the same, but the "quality" would be different; they would be button pushers and dial watchers rather than unskilled gangers. This being the case, 1t is unlikely that Asian workers (who constituted $53 \%$ of the firm's labour force) would be employed in these jobs because of language and literacy difficulties. Moreover, the jobs concerned would be less arduous and have more prestige than the type of work they replaced, and would probably, therefore, be more attractive to white workers. Th1s would further decrease the coloured workers' opportunities for obtaining such jobs even if they possessed the necessary qualifications.

Thus although the present generation of migrants have made some progress towards industrial integration, serious problems may still arise with regard to both the employment and occupational 
levels of succeeding generations unless this progress is maintained. The few examples given in this Chapter show that, in spite of some resistance on the part of white workers, coloured workers can be employed on skilled jobs. The danger lies in the fact that many flrms may decide to "leave well alone", or simply never really consider the wider implications of not employing skilled coloured workers in their own particular cases. 


\section{CHAPTER PIVE}

MANAGERIAL BELIEPS AND ATTITUDES CONCERNING THE EMPLOYMFNT OF COLOURED WORKERS : SKILL AND TRAINING

\section{Preliminary Summary}

Although opinions sometimes varied, managerial assessments of the skill level of coloured immigrants were largely consistent with the conclusions reached in Chapter Three on the basis of the available data in the literature. In general, coloured workers were regarded as being less skilled than British workers and, amongst the different coloured groups, Asian workers tended to be found less skilled and less industrially experienced than West Indians. With regard to training, few difficulties appear to have been encountered in the case of West Indians, but problems of language and lack of Industrial sophistication were often reported in the case of Asian workers. Various methods by which such problems have been, at least partially, overcome are described at the end of the Chapter. 


\section{Introduction}

Duxing the next two chapters we shall consider managerial beliefs and attitudes towards the employment of coloured workers. The availakie "objective" data concerning the skill level of coloured immigrants and the vacancies avallable to them in British industry during the 'Pifties have already been examined in Chapter Three. It was concluded that coloured 1mmigrants tended to be less skilled than their British counterparts and that there was a considerable shortage of labour during much of this period, especially in the less skilled occupations. The extent to which these two factors complement each other might be expected therefore materially to have assisted the industrial integration of the Immigrants.

However, it would be unrealistic to assume that human beings react solely to the objective situation. They react rather to their 'definition of the situation' and the same objective situation may yleld two radically different subjective ones. The shortage of labour wh1ch management sees as a knotty problem may be regarded as a positive factor by the workers to whom it gives added securlty and perhaps increased earnings through overtime. Similarly, the immigrant who views himself as adequately qualified for a skilled job may not be so perceived by an employer who "knows" that all coloured workers are completely unskilled. Thus, it will be not so much the facts about coloured workers, so much as what managers and to some extent white workers, belleve to be the facts which will determine whether a particular firm employs coloured workers, and if so, 
In what numbers, of which nationality and on which jobs. As Myrdal (1944) says, "it is the popular beliefs, and they alone, which enter directly into the causal mechanism of interracial relations. The scientific facts of race and racial characteristics ..... are only of secondary and indirect importance.... they are only virtual but not actual social facts."

However, one must be careful not to pursue this line of argument too far. When faced with a complex phenomenon, it is undoubtedly easier to study what people say are the facts (their 'definition of the situation') than to determine what these 'facts' actually are. It is tempting, therefore, to use this method as an 'easy way out' - to use popular beliefs as an alternative or sutstitute for the facts rather than as a different, though equally valid, set of data. To do so, however, seriously limits the use to which the data can be put. Whilst a study of popular beliefs may yield the immediate social cause of a phenomenon, both the popular beliefs and the 'facts' are necessary to provide an adequate basis for action.

This can be 1 llustrated by means of a hypothetical example. We have already shown that coloured workers tend to obtain jobs lower in the occupational scale than white workers. Let us suppose, for the sake of argument, that we discover that this is because managers believe that, coming from an agricultural background, coloured workers lack the manual dexterity for skilled industrial jobs. Irrespective of whether coloured workers do in fact lack the manual dexterity for skilled industrial jobs, this managerial belief would represent the 
Immediate cause of the phenomenon in question. However, this does not tell us what steps to take should we wish to raise the occupational level of coloured workers. If the belief could be shown to be invalid, then attempts to persuade managers that their assessment was inaccurate would be in order. On the other hand, training schemes designed to increase the manual dexterity of coloured workers or something of this nature would be necessary if the belief were shown to be val1d. Thus a knowledge of the 'facts' about the manual dexterity of coloured workers would be vitally necessary in order to determine which course of action to take.

Nevertheless, the fact remains that it is more difficult to determine the 'facts' than to examine the belief systems. To carry out an adequate objective study of, say, manual dexterity amongst coloured workers would have been a major research undertaking in 1tself, and even this would have been a comparatively straightforward matter compared with the objective study of other, more intangible, subjects such as diligence and amenability to disc1pline. In the course of a three year research project, sich as the one on which the present work is based, It would have been possible to examine in this manner only one, or at the most perhaps two, of such factors. On the other hand, it proved possible to examine a wide variety of beliefs concerning these factors during the same period. There is a strong argument, therefore, for examining the bellef systems first, especially in an underdeveloped fleld where there are a number of factors involved. Firstly, it enables the research 
worker to present a general outline of the whole field, thus providing a frame of reference to which it would be possible to relate subsequent more detailed studies. Secondly, to analyse the facts without first examining the beliefs would not allow the research worker to discover whlch facts were the socially relevant ones and might lead to a large amount of time being wasted on the collection of relatively unimportant data. For this reason, the writer has malnly concentrated upon the study of the bellefs of managers and workers concerning the employment of coloured workers. Where possible, however, some attempt has been made to check the validity of these beliefs by comparing them with the avallable data in the literature, with the actual employment conditions of coloured workers in the firms concerned, and by comparing the bellefs expressed by different respondents. In this chapter we will be concerned with skill and training, but we will turn to such factors as diligence, flexibility, supervision, labour turnover, and so on in later chapters.

2. Managerial Bellefs Concerning the Skill of Coloured Workers In the non-directive survey, only three managers expressed bellefs concerning the skill level of West Indian workers. Their opinions varied as much as did those of the academic authorities quoted in Chapter Three. The Personnel Manager of Insign Spring Co. sald:

We get a lot of coloured people coming for jobs and we have to turn them away. Experience is 
needed and Jamaicans haven't got the experience.

This firm employed only 20 to 25 West Indians out of a total of 800 to 900 employees, all of them in unsk1lled work.

On the other hand, Brierley Metal Works, which also employed few West Indlans (about 6 out of a total labour force of 2,300 , of whom about $30 \%$ were Aslans) apparently did so for the opposite reason. The Labour Manager said:

The firm employs very few West Indians - about half a dozen ..... Most of the Jamaicans are very well educated: much too highly educated to accept labouring jobs. Imploying West Indians just doesn't work out: they soon want to be boss and they can't all be boss.

In both these cases, it seems likely that the opinions expressed were rationalisations, either conscious or unconscious, for the small number of West Indians employed by the firms, At Ensign Spring Co., as we have already noted, several of the jobs, in fact, required very little previous experience. Similarly, the other respondent's claim that West Indians were much too highly educated to accept labouring jobs, whether he himself belleved the statement or not, was simply not a statement of fact. West Indlans were employed on labouring jobs in many of the other firms visited by the writer and in several cases, e.g., Central Glass Works, on the most menial of labouring jobs. On the other hand, the firm in question employed a high proportion of Asian workers, compared with whom West Indians are more "educated" 1 
and also perhaps more eager to obtain higher status jobs (hence the respondent's claim that they "wanted to be boss"). Thus it seems likely that the basis of the Labour Manager's assessment was not the fact that West Indians were completely unwilling to accept labouring jobs, but that they were less content than falan wcrkers to remain in labouring jobs and therefore, from the firm's point of view, made less satisfactory workers.

At Drop Forgings Itd., a firm emploving 55 West Indlans out of a total labour force of 450 men, the assessment of the skill of West Indian workers was somewhat similar to that in the Ensign Spring Co. The Personnel Manager said that, in general, West Indians were not skilled enough for the skilled jobs, especially the highly skilled jobs requiring apprenticeshlp.

Most of the Jamaicans we employ are completely unskilled: about half of them were cultivators.

However, this case differs from the previous one in several respects. Firstly, the firm was prepared to employ a much higher proportion of West Indians ( $12 \%$ compared with about $\left.2 \frac{1}{2} \%\right)$; secondly, the firm employed two skilled men who had recelved their training in Jamaica; and thirdly, a number of West Indians had been trained for skilled positions by the firm.

In the directive interview survey, managerial assessments of the skill level of West Indian workers were obtained in ten firms. In eight cases it was stated that west Indians were, in general, less skilled than British workers. ${ }^{1}$ In one of the remaining two firms, Sovereign Steel Works, the respondent evaded

1. Firms 15, 17, 18, 19, 20, 21, 22, and 27. 
the question by saying that most of the coloured workers had had some experience before coming to work at the firm. By this he meant that they had not come "straight off the boat", but had worked in other firms in Britain first. However, he said later that the firm had no skilled coloured workers and those who worked on semi-skilled jobs had been trained by the firm. Finally, the Personnel Manager of Pentland Alloys stated that West Indian workers had experienced no difficulty with the unskilled and semi-skilled jobs which they had been given, but he did not think that they could be employed on skilled jobs because they lacked the necessary apprenticeship training. In three firms, it was stated that by British standards West Indians were sometimes less skilled than they claimed to be.

In general, they are less skilled. We have had a number who claimed skill, but were tested and didn't come up to standard. If they have had a Iittle experience, they tend to think they are skilled.

(Labour Officer, Hamilton Engineering $\mathrm{Co}_{0}$ )

The bloke who claims to be a tradesman is generally of a lower standard than we would expect. They have not had the experience of complicated work in big firms: they are not capable of a variety of work. We haven't had one who could pass the trade test we set for English applicants. We had one who had good 
references from a small firm, but who wasn't good enough for us. If they had some sort of post-graduate apprenticeships, they might do all right, but we have had no reason to do this.

(Personnel Officer, Grange Graphite Co.)

We have never been able to put a West Indian on electrical or engineering jobs because the ualifications claimed do not come up to our standard.

(Personnel Manager, Sterling Metal Co.)

Codable answers concerning the skill level of West Indian workers were obtained from 39 firms in the questionnaire survey. They were said to be less skilled than British workers in 22 cases and "about the same" in 17 cases. In none of the firms was it stated that West Indians were more skilled than British workers. We now turn to managerial bellefs concerning the skill level of Aslan workers. In the directive interview survey, managers in fourteen firms out of fifteen stated that Asian workers were less skilled than native British workers. The one exception was Soverelgn Steel Works, where the manager again avoided the question by saying that most of the coloured workers had previously had some experience in other firms. In six cases, comparisons between the skill level of Asian and West Indian workers were obtained. In Annerley Iron Poundry and Tool Steel Itd., it was sald that West Indlans were slightly tore skilled. The Personnel Officer of Grange Graphite Co. stated that West Indians were always of a higher skill - he had never come across an Astan worker who claimed to be anything other than a labourer. 
In Quality Steel Co., Sovereign Steel Works and Polton Rolling Mills, however, no difference had been found between the skill level of Asian and West Indian workers.

The results of the questionnaire survey with regard to the skill level of coloured workers are presented in Table 15. It will be seen that the majority of respondents described Asian workers as less skilled than British workers and that Asian workers, especially Pakistanis, were assessed as being less skilled in a higher proportion of cases than West Indians.

Table 15: Managers' Assesments of the Skill level of Coloured Workers (Questionnaire survey)

\begin{tabular}{|l|c|c|c|c|}
\hline \hline Nationality & $\begin{array}{c}\text { More skilled than } \\
\text { British Workers } \\
\text { (Percentage) }\end{array}$ & $\begin{array}{c}\text { About the sane as } \\
\text { British Workers } \\
\text { (Percentage) }\end{array}$ & $\begin{array}{c}\text { Less skilled then } \\
\text { British Workers } \\
\text { (Percentoge) }\end{array}$ & $\begin{array}{c}\text { No. of rirms } \\
\text { Responding }\end{array}$ \\
\hline West Indians & 0 & 44 & 56 & 39 \\
Pakistanis & 0 & 21 & 79 & 19 \\
Indians & 0 & 37 & 63 & 33 \\
Arabs & 0 & 23 & 77 & 13 \\
Africans & 0 & 27 & 73 & 11 \\
\hline
\end{tabular}

Thus far we have been concerned only with formal training in skilled trades. With Asian workers, however, the level of industrial sophistication is also an important consideration. Not only did Asian workers tend to be considered less skilled than British workers, but some managers further suggested that they often lacked even the most elementary knowledge of incustry and industrial techniques, knowledge which would be regarded as 
almost axiomatic by anyone brought up in an industrialised society whether they had actually worked in industry or not. ${ }^{1}$

At Bradfield Foundry, for example, several Arabs had been employed, none of whom had ever worked in a factory berore. When first employed, according to the Works Superintendent, they had to be taught how to use a broom, which they held near the head Instead of at the end of the nandle; how to use a wheelbarrow, which they pushed along with the legs scraping on the floor; and how to put on protective gloves (used when working at the grind wheels), which they were incapable of doing unassisted. In other words, they had to be taught how to be labourers. Sinilarly, the Labour Manager of Edge Tools stated: Aslan workers do not know many things which are just taken for granted with whites. This causes

1. This question was touched upon by Wood (1960) in connection with the allegedly slow work tempo of coloured immigrants. He states: "The most common complaint about coloured people of both sexes and all nationalities is that they are often slow workers to begin with, and we have heard this in almost every town from a variety of sources. The immigrants were not brought up in an industrial atmosphers where the child picks up almost unconsciously the att1tudes and unspoken assumptions of factory life. They have to accustom themselves to the tempo of work and alien environment of Industry .... all this cannot be learned in a day by immigrants with a rural background who are not used to gadgets and machinery." Although this coincides to some extent with the findings of the present study, two points need to be made. Firstly, not all managers said that coloured workers were slow at first: some, as will be seen in Chapter S1X, stated that they were fast at first but slowed down later. Secondly, at least three factors seem to be involved in the work tempo of coloured immigrants: 1) level of industrial sophistication; 2) speed of learning; and 3) attitude towards work, once trained. In general, complaints about factors 1) and 2) occurred mainly with respect to Asian workers and in relation to factor 3) mainly with respect to West Indians. Although undoubtedly relevant, therefore, the question of industrial sophistication cannot be advanced as the sole explanation for the slow work tempo sometimes found amongst coloured workers. 
a strain on supervisory time. The firm employs more supervisors than usual and pays them higher wages than normal. It is an invisible cost of employing Pakistanis.

The respondent claimed that the Pakistanis' lack of industrial sophistication not only caused difficulties in training, but was also a danger to themselves. They had been told not to touch moving parts of machinery, he stated, but they did not realise the danger. One Pakistani, for example, had been told to stop a grind-wheel and had attempted to do so, not by switching it off, but by putting his hand on the wheel. Fortunately he had not been badly hurt and, according to the Labour Manager, there had as yet been no major accidents.

In the directive interview survey, Asian workers were said to be "accident prone" in seven ${ }^{1}$ of the fourteen firms in which they were employed. Some of the managers' comments were as follows:

Our product looks the same when it is hot as when it is cold. Asiatics are prone to pick it up and touch it when it is still hot. We haven't had any serious aceidents, but minor accidents, they are prone to.

(Personnel Officer, Grange Graphite Co.)

There is a tendency for coloured people to be accident prone. It's probably due to lack of Industrial experience. It may also be the fact that they aren't in a position to read

1. Firms 22, 23, 25, 26, 27, 28, 30 . 
all the safety propaganda. ${ }^{1}$ We take industrial experlence far too much for granted; it's not lack of intelligence.

(Personnel Manager, Sovereign Steel Works )

We have found this (accident proneness) ourselves

in the Hot Mill. There seems to be a lack of appreciation of danger. Also, they see our blokes doing things and try to do the same, although they are not as experienced.

(Production Services Manager,

Blackford Rolling Mills)

The unskilled (Asian workers) have been more accident prone than our own people. We have made our own assessment of this. We think that it is due to the change of environment. They are surrounded by mechanical things of which they have no knowledge whatsoever.

(Personnel Manager, Castle Iron Co.)

It w1Il be seen that as in Edge Tools, "accident proneness" tended to be attributed to the Asian workers' lack of industrial sophistication. In none of the firms was it suggested that West Indians were accident prone.

Apart from lack of industrial sophistication, another difficulty which often arises in the employment of Asian workers is that of language. In the questionnaire survey, one respondent stated:

1. In this firm, danger notices in foreign languages had been put up in certain hazardous areas. Because of the relatively high illiteracy rates amongst Asian immigrants, however, this could be no more than a partial solution to the problem. 
You appear to have missed out one very important factor, at least as far as Pakistanis are concerned. I refer to the barrier of language. ${ }^{1}$ We have employed up to eight Pakistanis in this factory and have found that, although they are good workers, we are necessarily limited in our use of them due to the difficulty in getting over to them what is wanted with regard to any particular job. Th1s means, of course, that we have to teach them thoroughly on one job and leave then on that, although some of them would have the ability to carry out a slightly more skilled job than the labouring jobs they are doing.

This example suggests that, in some cases, the ability to speak Engl1sh can be regarded as the equivalent of an industrial skill In the immigrant workers, in that language difficulties may lead to training being necessary where simple order giving would have been sufficient in the normal course of events.

The question of language was mentioned in several firms visited during the interview surveys. In the non-directive survey, one $\mathrm{firm}^{2}$ gave the lack of abllity to speak Inglish as the reason why Asian workers were not employed, and in two further firms ${ }^{3}$ this reason was advanced as a contributing factor. In Components Itd. Asian workers who could not speak English were not employed. The Personnel officer stated:

At first the coloured workers were employed mainly on labouring jobs and sign language was used. Now

1. It was assumed that respondents would refer to the language problem, if relevant, in relation to the questions on training and supervision.

2. Regal Manufacturing Co.

3. Drop Forgings Ltd. and Central Glass Works. 
it is a matter of selection. The Personnel office selects those who can speak English.

Finally, in Edge Tools, a firm which did employ non-English speaking Asian workers, the Labour Manager stated that the language difficulties were "almost impossible" until a sign language was evolved.

In sixteen of the seventeen firms visited during the directive interview survey, language difficulties were mentioned in relation to elther training or supervision. The one exception was Torrington Cutlers where no Asian workers were employed. In the two other firms in which there were no Asian workers, language difficulties were advanced as a reason for not employing them. Pentland Alloys had decided to employ only West Indians after hearing of the problems encountered by other firms. Hamilton Engineering had employed Indians and Pakistanis in the past, but had found West Indlans to be "the better type of applicant, especially with regard to their command of the language." Moreover, they had never employed Asian workers who could not speak English with a reasonable degree of fluency. Similarly, in Leigham Cannery, where Asian workers were employed and in this case highly thought of, the abllity to speak and read English was a necessary qualification for obtaining a job. The Personnel officer stated:

All coloured workers are literate: illiteracy is a bar to employment. They must be able to read and speak English up to four letter words. We test prospective employees with a newspaper: we ask them to read a simple piece. 
At this stage, we will not examine the question of language difficulties further, but merely note that it is a probler which often arises with respect to the employment of Asian workers but does not occur in the case of West Indian or, of course, British workers. However, it is a question which will require more detailed examination wher we come to consider the training and supervision of coloured workers.

\section{The Training of Coloured Workers}

As might be expected, managers tended to rind Asian workers more difficult to train than either British or West Indian workers. Hanagers in several firms visited during the non-directive survey commented upon this. For example, the Labour Manager of Fdge Tools stated that the promotion of Pak1stanis to semi-sk1lled jobs had "only been half-way successful" because they were "not very bright." He described the introduction of Asian workers (mainly Pakistanis in this firm) into one of the semi-skilled jobs as follows:

The Polishing Shop was the hardest to staff. Pakistanis were tried there. It looked at first as if it wasn't going to work. It is impossible to put them straight on plece work because they wouldn't earn anything. We had to pay them a reasonable rate and hope for the best whilst they were being trained. It was a costly business to begin with - only about one fifth were trainable on semi-skilled jobs at first - but once half a dozen were established, they helped the newcomers and things became easier. 
Other comments were as follows:

Pakistanis are very slow at first. For the first month they are a dead loss to the firm. You have to be prepared to lose a month.

(Works Manager, Onega Metals)

If there are opportunities for up-grading and the man is suitable, the coloured worker gets his chance the same as anyone else. But this is the principle rather than the rule, because, in general they are incapable of being up-graded.

(Personnel officer, Components Ltd.)

In general, Arabs are a bit slow on the uptake.

(Works Superintendent, Bradfield Foundry)

The latter statement was contradicted by the Labour Manager at Brierley Metal Works who stated that although Arabs were, in the main, absolutely unskilled they were very quick to learn and made very good welders and oxy-acetylene cutters. Similar anomalies were found in the directive interview survey. In seven firms ${ }^{1}$ it was stated that Aslan workers tended to be slower to learn their jobs than British workers. A variety of reasons were given. In Grange Graphite Co. the Personnel Manager stated:

Initially coloured workers are much slower. With Asiatics it is largely physique. Except on the simplest jobs they never get to full capability. West Indians will eventually, but Asiatics never. Beyond a certain point we just have to let them 
be. Language is the first difficulty with

Asiatics and this is just insurmountable $I^{\prime} m$ afraid. We have to use the demonstration technique and this limits the jobs they can be trained for to those with a short cycle.

On the other hand, the General Manager of Stainless Steel Ltd. stated :

They are a bit slow, but once they've got 1 , they understand the job thoroughly. It could go both ways, inadequate training as well as slowness.

At Quality Steel Co. difficulties had arisen because the job on which coloured workers were mainly employed (the lower grades of set work) had to be taught in stages. The Personnel Officer stated:

You don't want to push them too much so you give them the basic essentials firgt. Then when you try to teach them more, they think they are being given more work for the same money, and they won't move on to the next stage without a lot of persuasion from the Departmental Maneger. If they lose their temper, they revert back to their own tongue and you can't argue with them.

At the Castle Iron Co. the Personnel Hanager stated:

The main (initial) difficulty was training from unskilled to semi-skilled. They are slower to learn due to the language difficulty and the adjustment to mechanisation as opposed to manual labour. They seem to be the kind of people who are not mechanically minded and they 
have had no training whatsoever in using their hands. Some of them we have been able to train to semi-skilled jobs, but out of the whole number we have employed, not more than $10 \%$ have been trained and have proved to be useful workers.

Finally, at Polton Rolling Wills the Labour Officer suggested that accident proneness contributed to the slower rate of learning of the Aslan worker.

They are a bit slower than the average Finglishman. There is the language difficulty and also they are accident prone. IThey arop things on their toes. They are less guick on the draw than the Englishman if you know what I mean, less quick to get out of the way of things.

However, it will be seen that a recurring problem was that of language. Language difficulties in the training of Asian workers had been encountered in all seven firms, and in one case it was suggested that this was the only reason for their slowness. The Personnel Manager of Soverelgn Steel Works stated:

Providing you can get hold of the langrage problem, they are no slower (to learn than the British worker). However, they usually are slower due to language difficulties.

In two other firms (Major Castings and Lelgham Cannery) managers stated that there was no difference between Asian and British workers providing difficulties with language did not arise. Both respondents stated that Asian workers took a pride in learning their job. The Personnel Officer of Leigham Cannery went into some detall on this question. 
There is no difference between the Pakistani and the local bloke providing he can speak the language. In fact, the Pakistani is better than the average white worker under present conditions. The majority of available whites are part of the floating population. The majority (i.e., the non-floaters) can get a good job and stick to 1t. The West Indians are reasonable - not an embarrassment - but not as good as the Pakistanis. The Pakistanis feel they have to succeed, even more than the West Indians. It may be that they have some incentive behind them. Their country is recently independent and possibly they feel that they must not let their country down.

By contrast, the Personnel Manager of Sterling Metal Co. claimed that Pakistanis were very slow to learn and were "strictly limited" in the type of job they could be given. Arab and African (mainly Somali) workers, on the other hand were described as "very adaptable and quick to learn." In this firm, according to the respondent, jobs requiring more skill were given to the Arabs and those requiring less skill to the Pakistanis.

Th1s again $1 \mathrm{~s}$ in direct contrast to Blackford Rolling Mills, where Arabs and Pakistanis were classed as members of the same group, and management had noticed no difference between them in relation to either skill or performance. The Production Services Manager said that both Arabs and Pakistanis picked up unskilled jobs and manual work very quickly. He added that it was very difficult to evaluate their potential ability because of the communication problem, but having 
overcome that, he had no doubt that some of them could be trained for skilled work.

In Steel Bars Ltd. the previous assessment of the Arabs' ability to learn industrial jobs was strongly endorsed. The Works Director stated:

We have five Arabs working in the mill and they have picked up handling tongs like shelling peas. They're experts. They are as good as whites who have had 20 to 30 years experience.

The respondent stated that, in general, the initial skill level of the Arab workers had been "very poor", but with a couple of exceptions, they had been very quick to learn. Originally, they had been employed on the lowest jobs in the sets, but they had been very keen to obtain promotion to the more skilled jobs.

After they have been here for about four months, the Arabs are straining at the bit. It's best not to hold a man back when he is trying to better himself, so we've let them have better jobs and 1t's always paid off. They have gone up to the top jobs on the back side in both mills. We haven't got an Arab on a low job now; white youths do these jobs.

The Arab workers, the respondent claimed, had a different attitude towards work from the white worker. When an Arab took over the lowest job in the set, he would try the job above when he ad the opportunity, so that when a vacancy occurred, he could do the job. The English worker, on the other hand, did not learn the job above in this manner and therefore was unable 
to step straight into the next job without further training. As a result of this attitude towards the job, the Works Director stated, the training of Arab workers had involved no problems whatsoever.

They virtually don't need training. The bottom job doesn't require any training and they pick up the next job on their own. When he's got a minute, he has a go at the job above. He's been watching the man who does the job.

Whilst this tends to confirm the assessment of the Personnel Manager of Sterling Metal Co. that Arabs were "very adaptable and quick to learn," it does not provide any confirmation of his adverse assessment of the capabilities of Pakistani workers. The firm had only employed Arabs, and the Manager could not say how they compared with other coloured nationalities.

In addition, two reservations need to be made about the assessment of Arab workers at this firm. Firstly, the Works Director said that the coloured workers employed by the firm were probably not representative of Arab workers as a whole.

We have sifted them over elght years. To say that they are above the average is putting it mildiy. I would say that the elght we have are superior to the white worker. Mind you, we have had one or two that were plain bloody awkward. You literally couldn't tell them to sweep the floor.

Secondly, notwithstanding his claim that the Arabs did not require training, the Works Director stated that the firm's biggest problem had been the language barrier. One Arab had 
been dismissed because they were unable to communicate with $\mathrm{hlm}$, and the Arabs' lack of facility with Inglish was given as the reason why they could not be promoted to the position of head roller.

In general then, managers interviewed during the directive interview survey thought that language difflculties, lack of Industrial sophistication or lack of apprenticeship training would prevent Aslan workers from obtaining skilled jobs. In seven Plrms, 1 it was stated that they could do semi-skilled jobs, but in a further four firms there were some reservations even about this level of work. In three cases, ${ }^{2}$ it was stated that some Asian workers could do semi-skilled but the remainder only labouring work, and in the other case ${ }^{3}$ the respondent claimed that Aslan workers could only do certaln types of sem1skilled jobs. In Stalnless Steel Ltd. the General Manager assessed the situation as follows:

There is a small percentage who could be skilled and a small percentage who could be semi-skilled and then you've got the workers and the drones. You get the same categories with white workers, but the percentages are not so good with coloured workers. You get more at the lower end of the scale and less at the upper end than you do with white workers. We have had about twenty to twenty-pive coloured workers at the f1rm altogether. Only two could have made skilled workers, four semi-skilled, about ten labouring and the rest no good.

1. F1rms 19, 20,22, 23, 25, 27 and 30.

2. Firms 16,18 and 28 .

3. Firm 15. 
Finally, the Personnel Manager of Sterling Metal Co. again differentiated between Pakistanis and Arabs. He stated that whereas the Pakistanis were strictly limited, the Arabs could go as far as they were permitted.

Comparatively little data were obtained on the training of West Indian workers. This, in itself, would seem to suggest that it was not perceived by managers as being a serious "problem" as was often the case with Asian workers. What data there are tend to support this contention.

The Personnel Manager of Drop Forgings Itd, stated that only about half a dozen of the 55 West Indians employed by the firm had been made stampers (a skilled job), but added that "you wouldn't get any more out of the same number of whites." Similarly, the Personnel Manager of Trafford Iron and Steel Co. said that there had been isolated cases of men finding jobs too difficult, but this had not been associated with colour.

When asked about the training of West Indian workers, the Personnel Manager of Pentland Alloys Ltd. stated:

They've always had a good name. We have never had any trouble on the jobs we've given them. They have done well and been indistinguishable from the white man in performance. In fact some of them have been a good deal better.

He said that he had no doubt that West Indians could be trained for semi-skilled jobs, al though he was dubious about skilled work because five years training was necessary. In Hamilton Engineering Co., on the other hand, the 
Personnel Manager thought that, on the average, West Indians were slower to learn than the British workers, although there were exceptions.

It depends entirely on their background. If the Jamaican has spent some time in a factory he is reasonably fast. If he has been a plantation worker, then he is slow.

Nevertheless, the respondent was of the opinion that the majority of West Indians were capable of being trained for semi-skilled jobs and, in fact, some fifty per cent of the West Indian employees had progressed to sem1-skilled jobs such as crane driver, slinger and machine operator.

The above firm had employed Asian workers, but West Indians were preferred:

We have employed Pakistanis and Indians. Jamaicans have been the better type of applicant especially with regard to their command of the language. We used to get the "uncle" coming in with four men trying to get them a job. He could speak Bnglish but didn't want a job and the ones that did want a job couldn't speak English.

Where comparisons were made between the different coloured groups, West Indians tended to be found easier to train. The Personnel Manager of Major Castings Ltd. stated that West Indians showed more initiative than the Pakistanis.

I don't think they (the Pakistanis) are as adaptable. They can't do all the semi-skilled jobs. The West Indians are rather ahead of the Pakistanis in this respect. 
In Torrington Cutlers, the Works Director claimed that the West Indian worker was easier to train than the Pakistani and compared favourably with the local unskilled worker. ${ }^{1}$ He stated that West Indlans could be trained on semi-skilled jobs and many could be trained for skilled work. Finally, the Personnel Officer of Grange Graphite Co. stated that although both Asians and West Indians were much slower workers initially, West Indians would eventually reach full capability whereas Asians never did.

Aslatics are almost all on labouring and semiskilled work. Language, education and physique hold them back. The better West Indian has the potentlal to be trained for skilled jobs. We have never tried $1 t$, but I think we could do $1 t^{2}$

There were, however, two exceptions. Firstly, as noted above, the Personnel Officer of Leigham Cannery stated that although West Indlans were "reasonable" at learning their jobs, Pakistanis were better. And secondly, the Personnel Manager of City Transport claimed that all coloured workers were slow to learn and that Pakistanis and West Indians were no different in this respect. The respondent noted, however, that they all got through the training course all right.

1. However, it should be noted that the respondent thought that the local worker was of a very low standard, and that the West Indian workers would not compare as favourably in other areas.

2. The respondent stated: "As far as the West Indians are concerned there is no real difficulty, except for the fact that they think they can do the job as well as the man who is training them. They don't like you to start with the fundamentals: they are insulted. But you've got to start with the fundamentals. This limits them and it's their own fault. They are like stubborn children." 
Methods used in the Training of Asian Workers

Given that certain difficulties arose in the training of coloured workers due to the language barrier, what methods were employed to overcome this problem? By far the most common was the "demonstration technique": the white workers already employed on the job showed how it was done by means of sign language and the Asian workers learnt by imitation. ${ }^{1}$ This method was summed up by one manager as "demonstration of movement." 2

The demonstration technique has, of course, 1ts limitations. The Personnel Officer of Grange Graphite Co. stated that the foremen had been put through TWI (Training Within Industry) mainly with a view to the fact that many people could not be trained by ordinary methods. Nevertheless, he thought that Asian workers, because of the language difficulty, were limited to jobs with a short cycle which could be demonstrated. Similarly, one of the foremen at Bradfield Foundry thought that some jobs were more susceptible to the demonstration technique than others. He was somewhat dubious about training Aslan workers to be moulders (he had been a moulder himself before being promoted) partly because of the language difficulties involved.

Moulding is the kind of job you must grow up with. Although it is mechanised, there is still a lot of skill in 1t. The human element makes all the difference between a good mould and scrap. This is

1. This method of training was mentioned in eight firms al together $(2,15,22,23,24,27,28,30)$.

2. Personnel Manager, Castle Iron Co. 
where the difficulty arises with forelgn workers. In the Fettling Shop, you can show a grinder a well-ground casting and a badly ground casting and say: "This one is bad, do it like this." But this is not possible in moulding where there is no finished product. Two moulds may look alike, but one will produce a bad casting and the other a good one. If the sand is pressed too tight, the metal won't run and if it is packed too loose, the casting swells. It is difficult enough to teach an Inglishman to do it just right, but it is doubly difficult with a foreigner because he can't understand you. The fact that they say they understand you is no guarantee. They may say they understand, but when you leave them to it, they do it wrong. If you could solve the language difficulty, you would solve half the colour problem in industry.

Nevertheless, it should be noted that foreign workers, Italians as well as Indians and Pakistanis, had been trained as moulders, so obviously the language difficulties were not insurmountable in this case.

Another quite common method of training Aslan workers was the use of instructors who could speak their language. In one case (Major Castings Ltd.) the instructor was a white foreman who had lived in Pakistan, and according to the Personnel Manager, knew the language and the country. More usually, however, Asians themselves were used as instructors. At Annerley Iron Foundry, for example, the Works Manager said:

The Arabs train each other. When we are a man short we ask one of the Arabs we already have to bring a man in. He then trains him. 
Other examples include Bradfield Foundry where it was a policy to put someone who was just starting with a member of his own nationality so that he would receive help with learning his job; Edge Tools where the established Pakistani workers in the Polishing Shop assisted the newcomers thus considerably easing the firm's training difficulties; and Omega Metals where an English-speaking Pakistani chargehand undertook the training of all his fellow countrymen irrespective of the job on which they were employed. Further details of the latter case will be given in the next chapter.

Finally, in two cases firms went so far as to modify the jobs concerned to make them more suitable for Asian workers. In Muirhead Foundry the Personnel Manager stated:

Coloured workers (mainly Indians) work on every operation in the foundry except fitting. We have reduced the elements of the jobs to really simple pieces of work so they can't go wrong.

In the other case, Bradfield Foundry, an ingenious method had been evolved to overcome the language (and also literacy) barrier in order to enable Asian workers to be employed on a particular job. The Technical Controller had trained four Indlans to charge the furnace. In essence, the job was a relatively simple and menial one: it consisted merely of wheeling barrow loads of the necessary raw materials from the stock piles and loading them into the furnace. However, the difficulties arose because it was necessary to weigh the barrow loads before emptying them into the furnace and the Indians were 
illiterate as well as being unable to speak English. The situation was further complicated by the fact that the necessary ingredients varied according to the type of metal being produced, grey pig iron, grey scrap, Durham coke and limestone being required for grey iron, and malleable scrap, malleable pig iron, Welsh coke and limestone being required for malleable iron. In addition, the proportions also varied according to the type of metal being produced; e.g., the proportion of grey iron scrap needed for grey Iron was not the same as the proportion of malleable iron scrap needed for malleable 1ron.

According to the Technical Controller, it took six months constant supervision to evolve an infallible system. This was eventually done by coding the various ingredients. Grey iron was given a red code and malleable iron a blue code. The varlous ingredients were designated by shape, e.g., scrap by a square and pig iron by a triangle. Thus malleable scrap would be a blue square, grey scrap a red square, grey pig iron a red triangle and so on.

The various stocks of raw materials were sign posted so that when, say, grey iron was being produced, the Indian knew that he had to obtain coke from the pile marked with a red circle, scrap from the pile w1th the red square and so on. He then filled the wheelbarrow and wheeled the load onto the weigh-scale. To obtain the correct proportion of the ingredient, he simply had to ensure that the pointer came to rest opposite a particular mark on the face of the welgh-scale. For each grey iron ingredient there was a red mark on the dial and for each malleable iron 
ingredient a blue mark, each corresponding to the correct amount of the ingredient to be charged into the furnace for the type of metal being produced. These marks, it should be added, signified the weight of the raw materials plus the weight of the barrow, so that it was not necessary to subtract the latter. ${ }^{1}$

By this means, the Indians were able to "weigh" the various ingredients without being able to speak Inglish, read English or calculate in terms of the British system of weights and measures. The Technical Controller concluded:

The attitude used to be: "You can't train them because they are Indians." I feel that they should be treated like intelligent children. Intelligent children can be taught and so can Indians, because they are keen to learn. I could put an intelligent Indian in the foundry laboratory and have him doing chemlcal analysis in three months, not by teaching him the chemical formulae, but by training him with a colour code system.

The success of this method of training suggests that, if firms were prepared to go to some trouble, Astan workers could be trained for many jobs now thought to be beyond their capabilities. Nevertheless, even apart from the lengthy training period required, this method, in common with the other techniques we have discussed, suffers from a major drawback both for the Asian workers and the firms concerned. It involves the learning of a particular job by rote, as it were, and transfer of training to other, similar jobs

1. All the barrows used on this job were, of necessity, of a standard weight. 
may be negligible. Thus the Indian workers in the above example were perfectly able to "weigh" materials at Bradfield Foundry, but would have been unable to do so at another firm unless the same colour coding systern were used. Similarly, an Asian worker trained to do a semi-skilled job by the demonstration technique may require almost complete retraining if the firm introduces a modified version of the machine or wishes to transfer him to another semi-skilled job. This brings us to the question of the flexibility of colourea workers, which will be examined in greater detall in the next chapter.

4. Summary

We noted at the beginning of this chapter that managerial assessments of the skill of coloured workers varied considerably. It w1ll be seen that this applies equally to the question of training. Occasionally, diametrically opposed views were encountered. Thus one manager claimed that West Indians were too unskilled for anything other than labouring jobs whilst another stated that they were "too educated" to accept such work. Similarly, one manager claimed that Arabs were "slow on the uptake" whilst others reported that they were very quick to learn.

Nevertheless, certain patterns could be discerned. Although generally regarded as less skilled than British workers, West Indians tended to be found more skilled and easier to train than Asian workers. Several reasons for the Asian workers comparatively slow rate of learning were suggested, including inferior physique, 
inadequate training, difficulties involved in teaching a job in stages, lack of industrial sophistication and accident proneness. However, the main problem appeared to be that of language. Varlous methods of overcoming the language and other problems had been evolved. Most common was the demonstration technique, but job modification and the use of instructors, white or coloured, who could speak the language of the trainees, were also encountered in some cases. These methods had met with varying degrees of success in different firms. Two respondents claimed that language difficulties limited to a considerable extent the range of jobs which Asian workers could be taught. However, the fact that they had been trained as moulders and furnace chargers in Bradfield Foundry strongly suggests that an equally important factor is the amount of time and trouble management is prepared to take, which is again related to the difficulty of obtaining British workers to do the jobs concerned. 
CHAPTER SIX

MANAGERIAL BELIEFS AND ATTITUDES CONCERNING THE EMPLOYMENT OF COLOURED WORKERS : DILIGENCE, BLEXIBILITY AND SUPARVISION

\section{Preliminary Summary}

We have already seen that the language problem gave rise to difficulties in the training of Asian workers. In the present chapter it will be shown that, even when trained, the Asian workers' lack of facility with Finglish often made supervision more difficult, and that the training methods used to overcome the language problem sometimes made Asian workers less capable of being put on different types of work than either British or West Indian workers. It might be expected, therefore, that the Asian workers' employment opportunities would be correspondingly limited, but, as we saw in Chapter Four, this was not the case in the present sample oi firms. One reason appears to be that Asian workers are often regarded as being more hard working and more amenable to discipline, providing the language problem can be overcome, than West Indians or even British workers in some cases. For many firms, it would seem, this more than compensates for the difficulties encountered in training and supervision. 
1. Introduction

In the previous chapter, with its emphasis on skill and training, we were concerned, in effect, with attitudes towards the coloured immigrant as a potential rather than an actual worker. We now turn to a conslderation of managerial attitudes concerning the "standard" of coloured workers once they have become trained and fully functioning members of the labour force. In their assessments of coloured immigrants as workers, managers seemed mainly to be concerned with two sets of factors, which, for the sake of convenience, we will call "diligence" and "susceptibility to supervision". Diligence includes both the willingness and the ability to work hard, and susceptibility to supervision refers not only to amenability to discipline but also to the abllity to understand and comply with orders. A further topic mentioned by some managers, mainly in relation to Asian workers, was the question of flexibility. We are partly concerned here with amenability to discipline in that one of the factors involved is the willingness of coloured workers to be transferred from one job to another. However, the coloured workers' capability of being put on different jobs is another important factor, and the question will, therefore, be discussed in a separate section. At the end of the chapter we will also examine various methods which have been evolved in order to overcome language difficulties in supervision, and in particular the use of bi-lingual "go-betweens". 


\section{Diligence}

In the non-directive survey, the majority of managers thought that West Indians were slow workers. However, explanations as to why this should be the case varied somewhat.

According to two respondents, West Indians were lazy. At Westwood Foundry, sixty West Indians had been employed in 1954 because workers were needed at short notice. The Labour Officer stated:

Within a month, there were only three left.....

The main trouble was that they did not come here to work..... We have employed a few West Indians since, but none have been much good. Those we have now are all in menial jobs that won't break their backs.

Similarly, the Works Manager at Omega Metals was most vehement in his condemnation of West Indian workers. He stated:

West Indians are just no good. They just won't work. "No-hopers" we call them. We have tried employing them periodically and it is always the same. They start off "red hot" during the first week and by the end of the next week, they are fast asleep. Some of the West Indians we employed didn't even last a fortnight.

On the other hand, some managers seemed to think that West Indians were slow workers, not so much because they were lazy, but becauge they were incapable of working at a fast tempo.

The Jamalcans are naturally slow. We only have one on the production side. He is $0 . K$. because 
he has to keep up with the conveyer, but he would be terribly slow if we put him on a job on which he could go at his own pace.

(Works Superintendent, Bradfield Foundry)

Fifty per cent of the Jamaicans we employ have been used to a very slow tempo. Some of the young ones can buckle down and keep up with the pace, but some have great difficulty keeping up.

(Personnel Manager, Drop Forgings Ltd.)

We only employ a few Jamaicans - you have to sort them out a bit more. They are not in the same class of worker (as the Aslans) - a bit slower.

(Personnel Manager, Muirhead Foundry)

We prefer to employ Indians and Pakistanis because the West Indians tend to be happy go lucky.

(Personnel Officer, Components Ltd.)

In all the firms so far mentioned, with the exception of Drop Forgings Ltd., West Indians were compared unfavourably, elther directly or indirectly, with Asian workers with regard to diligence. At Drop Forgings, on the other hand, Indians had been employed during World War II but subsequently only West Indians had been employed because, according to the Personnel Manager, they worked harder and had the advantage of being able to speak Fnglish.

In the remaining firms, the attitude towaras West Indians was also somewhat more favourable, but no comparisons were made between West Indian and Asian workers as far as diligence was concerned. The Personnel Manager at Ensign Spring Co. stated 
that West Indians were: "jolly good workers; not such fast workers, but jolly good plodding workers." In Central Glass Works, the Personnel Manager claimed that West Indians were better time keepers and, according to some standards (e.g., labour turnover and absenteeism) more keen than British workers. Finally, at Bdge Tools, management had not been favourably impressed with the first West Indians they had taken on, and for a time had ceased to employ them. Later, however, mainly at the instigation of the local Employment Exchange, West Indians had been employed once more and the firm had developed a much more favourable attitude towards them. The Personnel Manager stated:

The West Indians we have now are all first class people. It's not true that they won't work. If you give them a job where they can earn good money, they will have a go.

In the directive interview survey, assessments of the diligence of West Indian workers were obtained in six firms. On the whole, more favourable views were expressed than in the non-directive survey, but again there was some variation.

In Pentland Alloys Ltd., Hamilton Fingineering Co, and Leigham Cannery, West Indians were said to be as hard working as British workers, although in the latter firm Pakistanis were thought to be even better. In Leigham Cannery and Hamilton Engineering Co. respondents stated that West Indians were capable of working at high speed on plece work, but in Pentland Alloys the Personnel Manager was somewhat dubious. He stated 
that al though they had done very well on the jobs they had been given (unskilled and semi-sisilled), he had gained the impression that they were not capable of working at speed - they seemed to be more phlegmatic,

In the remaining three firms, West Indians were described as "steady workers" in one case; ${ }^{1}$ in another the respondent claimed that, in general, they were not hard workers, although there were exceptions; ${ }^{2}$ and in the third, it was stated that Trinidadians were hard workers whereas Jamaicans were lazy, 3

The results of the questionnaire survey for all nationalities are presented in Table 16.

Table 16 : Nanegeriel Assessients of the Diligence of Coloured Workers (Questionnaire Survey)

\begin{tabular}{|l|c|c|c|c|}
\hline \hline West Indians & $\begin{array}{c}\text { Nore hard working } \\
\text { than British workers } \\
\text { (percentage) }\end{array}$ & $\begin{array}{c}\text { About the save } \\
\text { as British workers } \\
\text { (percentage) }\end{array}$ & $\begin{array}{c}\text { Less hard working } \\
\text { than British workers } \\
\text { (percentage) }\end{array}$ & $\begin{array}{c}\text { No. of } \\
\text { Firns } \\
\text { Responding }\end{array}$ \\
\cline { 2 - 5 } Pakistenis & 0 & 52 & 48 & 42 \\
Indians & 10 & 61 & 29 & 31 \\
Arabs & 0 & 64 & 36 & 14 \\
Africans & 0 & 67 & 33 & 12 \\
& 0 & 64 & 36 & 11 \\
\hline
\end{tabular}

In just under half the firms responding, West Indians were said to be "less hard working" than British workers. Asian workers,

1. Personnel Manager, Major Castings Itd.

2. Works Director, Torrington Cutlers.

3. Works Manager, Annerley Iron Foundry. The respondent was under the impression that both the West Indians employed by the firm were from Trinidad, but one later informed me that he came from Grenada. 
on the other hand, and in particular Pakistanis, were so described less often than the West Indians, and in the only three cases where a coloured group was described as "more hard working", the workers concerned were Pakistanis.

In the non-directive survey, Asian immigrants were highly regarded as workers in most of the flrms in which they were employed. At Bradfield Foundry in particular, several members of management spoke very highly of the firm's Asian employees. The Works Superintendent stated that the Indians were good workers and quoted several examples of their diligence. A Sikh, he claimed, had set a production record for moulding which had previously been thought impossible to attain, 1 and another Indian had been told to start work early at 6 a.m., but had clocked in at 5 a.m. and got so much work done that the firm decided to pay him for the extra time even though he had not been told to do 1t. In the same firm, the Technical Controller stated:

With coloured workers you have a different kind of problem from the one you have with white workers, but I'm not so sure I don't prefer this kind of problem to that you have with British workers, with organised unions and all that. These (i.e. the Asians) will work and that's a great advantage.

Simllarly, the Production Manager said: "I'd rather have these workers than British workers. It makes me ashamed of my own race, honest. British workers don't come here to work: they want

1. The respondent claimed that there was no restriction of output on the plece-work jobs; if one worker could set a higher rate, the others did not object but tried to equal 1 t. 
something for nothing."

The Works Manager of Omega Metals was equally enthusiastic about Pakistani workers.

Once they have been trained, they are very diligent and never late ...... It is worth putting up with the stupidity of the Pakistanis for two months because once they are trained, they work hard and go on working hard ..... they work a sixty hour week and just love 1 t.

Similarly, the Labour Officer at Westwood Poundry said that Indians and Pakistanis worked hard and earned good money, and in Mulrhead Foundry it was said that Indians did "hard graft." 1

However, there were some anomalies in the data. At Brierley Metal Works, the Labour Officer described Indians as "excellent workers", but claimed that Pakistanis were a little more educated - which they played on - and unless on piece work were less satisfactory than Indians. As a result, when a Pakistani left, the firm tried to replace him with an Indian because the latter "have an edge". Conversely, the Personnel Officer of Components Ltd. said that East Indians applied themselves better than West Indians, but of the East Indians the firm preferred Pakistanis because the Indians tended to be

1. In the latter case, however, the Personnel Manager did not think that Indian workers were as good as British workers. He said that Indian workers were getting greedy: they wanted exactly the same as British workers and they were not up to their standard. He then quickly added that, of course, they did get exactly the same as British workers - there was no difference in rates - and this wasn't fair because they did not deserve to get as much as the British worker when they were not as good as he was. 
more highly educated and therefore less likely to accept menial work and stick to it. These contradictory assessments are even more surprising when it is taken into account that the two firms were situated on adjacent premises on the same street.

In two firms it was stated that Arabs were not strong enough for heavy work.

They are much smaller in stature .... not quite suitable for heavy manual work and therefore quite limited.

(Labour Manager, Brierley Metal Works)

Arabs don't fit the b1ll for heavy industry.

(Labour Manager, Westwood Foundry)

On the other hand, the Works Superintendent of Bradfield Foundry stated that, whilst Arabs might be a bit slow on the uptake (cf. training difficulties in this firm), they were exceptionally good workers once they got to know the job.

Finally, the Personnel Director of Precision Engineers stated that coloured workers in general could not work as hard as white workers, mainly because of malnutrition (they did not eat properly even in Britain), but perhaps also because they were used to just sitting in the sun at home. It was unusual, however, to find both these stereotypes applied to both Asian and West Indian workers. More commonly, it was the West Indians who were said to be lackada1sical, and the Asians (In particular Arabs) who were said to be incapable of hard work because of physique. The following article in the Sheffield Star (9th December, 1959) Indicates that the latter stereotype at least has gained 
quite wide currency.

Steel mills proving too tough for coloured immigrants Sheffield's forges and rolling mills are proving too tough for many of the coloured workers who two years ago were flooding into the city looking for work. This is the view of Ministry of Labour officials who report a big exodus of coloured folk, mainly Arabs, from Sheffleld. The number of coloured workers registered as unemployed is down to 294, the lowest flgure for a considerable time. A year ago the figure was around the 600 mark.

Said a Ministry spokesman: "The bulk of these workers are Arabs, Pakistanis and Indians, usually falrly slight in build. They mostly come from peasant communities and just aren't strong enough for doing our heavy work. Also, whilst there is nothing in the nature of a colour bar, unskilled workers are picked on their merits and in many cases the merits of the coloured workers are not good enough."

An officlal of English Steel Corporation told The Star that although they had noticed no significant trend, the coloured men they employed were chosen because they were strong, hefty and suitable for the work they would be required to do.

In the directive interview survey, only one respondent suggested that Aslan workers were not strong enough for heavy work, and even he did not think that this meant that they were unemployable. The Personnel Officer of Grange Graphite Co. stated:

Aslatics are physically incapable of really hard work, of course. But some have been really good 
workers. On the most unpleasant, lowest paid jobs they are better than the Englishman who would want to be away from the job.

In Steel Bars Ltd., on the other hand, the Works Manager spoke very highly of the Arabs'willingness to work extremely hard and of their capability of doing so. Some examples of his remarks on this subject are as follows:

I don't like to use the term "machines" for human beings, but as far as work is concerned they are like machines. Before we got mobile (i.e. mechanised), the older men had got too old for man-handling and the younger men would not do the job, and this is where the Arabs came in. Now we are mobilised, but before, the Arabs did this job and they had about $50 \%$ more capacity than the white worker. If some heavy work was to be done, where the white worker would look for his mate to help him, the Arab will do it on his own. His attitude would be: "Let's get on with 1t, there isn't time to mess about." One backer (i.e. one of the Arabs working on the back side of the rolling mill) left because the team finished working after they had done what they call their stint, instead of working time out. If you ask a white worker to do a double shift, he will do it but he won't do another one that week. But if you asked an Arab to do a double shift every day for a week, he would go down on his knees and kiss your feet.

They are quite capable of working as fast as the white worker will let them. If we could get the white man to step up his speed, the Arab would match him. The white man is the brake to him on this particular job. 
Similarly, in Annerley Iron Foundry, Arabs were described as fast and hard working, once trained. The General Manager of Stainless Steel Ltd., on the other hand, thought that Asians, though willing workers, were not particularly fast. However, he did not appear to regard this as a serious disadvantage.

They are more like the tortoise. They are plodders and plodders always have their place in industry. They keep on plodding and they get there in the end. The white worker tends to work faster in short bursts with rests in between and by the end of the day, you might find that the coloured worker has done more.

As one of the Asian workers (an Arab) employed by this firm worked on a sledge-hammer job (knocking out castings), I asked the General Manager whether he thought Asian workers in general were capable of doing heavy work. He replied that they were like the British worker - some could and some could not. He described the worker concerned as "very strong - not big, but wiry."1

The other managers' assessments of Asian immigrants as workers were on the whole favourable.

I think the Pakistanis are all regarded as excellent workers. They will do as they are told until the cows come home.

(Personnel Manager, Major Castings Ltd.)

\footnotetext{
1. The respondent stated that he had no preferences with regard to the different Asian nationalities. ("Mankind is the same everwhere, there's 'good uns' and there's 'bad uns', and as long as I get the 'good uns' I don't care about colour. However, he added: "Mind you, I prefer these to the pure black: we had a couple of Africans who made a great show of doing nothing.")
} 
In my opinion, once he has absorbed the job, you get a good stint of work out of him.

(Personnel Officer, Quality Steel Co. re. Arabs and Pakistanis)

There's nothing special about coloured workers, good or bad. Eighty per cent of coloured labour is no trouble and gives a fair day's work.

(Personnel Officer, Tool Steel Ltd. re. Pakistanis and Arabs)

Providing they satisfy us within the six weeks training period, we will probably be satisfied with them. Pakistanis are a much better proposition than West Indians.

(Fersonnel officer, Leigham Cannery)

They are no different from the white worker they vary. In the rolling mills their cutput is the same as the others. Generally speaking, however, they are more anxious to please.

(Personnel Manager, Sovereign Steel Works. re. Arabs, Pakistanis and Somalis)

All the men are on piece work and bonus and they will work like hell for money.

(Personnel Manager, Sterling Metal Co. re. Arabs, Pakistanis and Africans)

They work hard once they have been trained.

(Personnel Manager, Ridgeway Steel Co. re. Pakistanis)

Once they have got hold of the job, they get on with it. Given a repetitive job, they get on with it and don't waste time. They need very little supervision.

(Labour Officer, Polton Rolling Mills. re. Arabs and Pakistanis) 
They are good workers - you will see Arabs lifting bars of metal that a white man would leave for the crane. There's very little to choose between Arabs and Pakistanis, but on the whole, I think that the Arabs just have it. Mind you, you get good Pakistanis and bad Arabs: there's not all that much in 1 .

(Departmental Manager, Polton Rolling Mills)

As usual, however, there were certain anomalies in the data. In two firms it was suggested that Asian workers worked very hard at first, but slowed down within a short period of time. The Personnel Manager of Castle Iron Co. stated with respect to Indians and Pakistanis:

Initially, they were jolly good workers - they would work twice as hard as an English bloke but after six weeks or a couple of months $50 \%$ degenerated into lazy, good for nothing slackers. We weeded these out pretty quick ..... We have had one or two Arabs, but they've not lasted long. They really have been idle devils.

The only way to keep coloured workers "on their toes", the respondent claimed, was constant supervision, without constant supervision they were inclined to be lazy. However this question did not arise in the case of coloured workers on semi-skilled jobs because they had to work "willy-nilly" at the same speed as their team mates.

In the other firm, Blackford Rolling Mills, Arabs and Pakistanis were employed as casual labourers during the yearly shut down. The Production Services Manager stated: 
For the first two or three days they are faster than our own men, but they quickly slow down, although not to an unreasonable rate.

Unlike the previous respondent, however, he regarded Arabs and Pakistanis as being, in general, satisfactory workers. In fact, at another point in the interview he stated:

They are very good workers: two Pakistanis could do in a day what five of our own engineering staff could do in a week.

Finally, there was some disagreement between the Labour Manager and the Personnel Manager of Sovereign Steel Works. The former clalined that Arabs were good workers, but Somalis were Inherently 1dle. The Personnel Manager, on the other hand, stated that it was very difficult to generalise: a lazy Somali was the same as a lazy finglishman, just one representative of his race.

\section{Plexib1lity}

The question of flexibility was mentioned only occasionally during the non-directive surveys. This would suggest that it is one of the less important factors in the determination of managerial attitudes towards the employment of coloured workers. Nevertheless, the few comments which were made are interesting in two respects: firstly, they referred only to Asian workers, and secondly, they were completely contradictory.

Two respondents clalmed that Asian workers were highly inflexible. In Bradeleld Foundry the Technical Controller stated: 
Forelgn workers, Aslans in particular, like to have one job that they can consider their own. They like to come Into one place where they can hang up their hat and coat and think: "this is my off1ce." I used to wonder what they wanted when they came up to me and said "steady job, steady job, all time one place," or asked for "all time casting," but 1t was simply the fact that they wanted the same job all the time. For example, that bloke over there (pointing to an Indian) is very good at his job: if he was off for any length of time we would have to replace $\mathrm{him}$ with two men. But if we were to change him on to another job, he would quit just like that.

In Brierley Metal Works, the Labour Officer stated that Indians were excellent workers and caused no trouble as long as you put them on a job, told them what to do and did not mess them about. If you change jobs, you've had 1t. They cannot adapt themselves to more than one job. The firm employs a few hundred Indians and not more than half a dozen can do more than one job.

Similarly, he stated that Arab workers were put on one job, taught that job, and that was the only job they knew.

On the other hand, two respondents, both in Bradfield Foundry, stated that they had found coloured workers to be flexible. When I asked the Production Manager how many people were general labourers, he replied that it was very difficult to say because a man might be doing a semi-skilled job one day and labouring the next. Pointing to a Pakistani who was shovelling sand for a bench moulder, he sald: "That man is on general 
labouring now, but he was on grinding a couple of weeks ago." He continued, "We have a very fluid labour force here. Frankly, I don't think our blokes would stand for so much messing about, but they are glad to get any job."

The Fettling Shop foreman stated that, if pushed, most of the workers in his department (Indians and Italians) could be put on different jobs.

One or two can only do one job, but there are also one or two who can do any job in the department. An Italian drill operator and the Sikh who is on Progress will do any job. If they are left on their own and finish one job, they will find another. The Sikh can not only do every job in this department, he can also operate the core machine, and he is sometimes "borrowed" to do this during lunch time.

He concluded:

Foreign workers are very helpful. They will come in early or work over when asked. The main thing is that they will always try to do something if asked, where our blokes would probably say it was too much. 1

Finally, in Edge Tools Ltd. a supervisor stated that it

1. The above statements of the Foreman and the Production Manager in Bradfield Foundry provide us with an interesting example of the same "facts" being given an entirely different interpretation. Whereas the Production Manager saw the Asian workers' willingness to do any job as arising from their low employment status, the Foreman saw this as being helpful. Conversely, the Production Manager regarded the British workers' refusal to try any job as a justifiable resistance to being "messed about", whereas the Foreman thought that they were simply unhelpful. 
was best to put coloured workers on one job, where they couldn't wander. However, whilst walking round the factory I noticed a Pakistani hitting a block of wood with a succession of knife blades. As he neither looked at the block of wood nor, apparently, inspected the blade afterwards, I asked what he was doing. The supervisor replied that he was usually a grinder, but that day he had been put on testing the blades to see whether the cutting edge turned over after striking the wood. This provides us with another example of an Asian worker being taken off his normal semi-skilled job and put on labouring work. In view of these discrepancies, it was decided to follow up this question in greater detail in the directive interview survey. Two factors seemed to be involved: the capability of coloured workers to be transferred from one job to another and their willingness to be transferred. Separate questions were therefore asked on these topics. Several managers stated that they could not answer either question because transfer did not occur or because they usually involved promotion. Such information as was obtained, however, was again contradictory. With regard to Asian workers, respondents in Stainless Steel Ltd., Polton Rolling Mills and Quality Steel Co. thought that they would ressent being transferred from one job to another. In the latter firm, as we have already noted, difficulty had been experienced in persuading Asian workers to learn the more complex aspects of their jobs after being taught the basic essentials. This problem had also been encountered occasionally in Tool Steel Ltd. The Personnel Manager stated: 
There has been some resistance to introducing new elements of the job. Having taught the basic essentials, some supervisors run up against a brick wall when they try to teach them something else. Their reaction is "not my job."

On the other hand, five respondents ${ }^{1}$ stated that Asian workers did not object to being transferred and one claimed that they actually liked it. According to the Personnel Manager of Sovereign Steel Works, they were always looking for something new: they had their eye on the main chance.

Similar inconsistencies were found with regard to the capability of Aslan workers to be transferred from one job to another. Four ${ }^{2}$ respondents claimed that Asian workers could not be put on different jobs and another ${ }^{3}$ stated that Arabs were adaptable whereas Pakistanis had to be put on one job and kept on it all the time. One of these respondents, the Personnel Manager of Castle Iron Co. stated that the Aslan workers' flexibility depended to some extent upon how different the two jobs were. He stated:

We have transferred them from one semi-skilled job to a similar semi-skilled job in the same department, but we have never tried putting them on a different type of job. With coloured workers, putting them on a different type of job would entail retraining. White workers are more flexible: if a white worker can do one semiskilled job, then the chances are he can do another.

1. Firms 18, 19, 22, 23, 24 .

2. Firms 15, 17, 25, 28.

3. Firm 24. 
In the Ridgeway Steel Co., on the other hand, a Furnace Supervisor claimed that difficulties had arisen when Pakistani workers had been transferred between very similar jobs. In this firm, Pakistanis were rarely put on different jobs, a fact which the Personnel lanager suggested was probably an indication that they were not considered flexible. However, they were sometimes put on the same job on a different shift. This, according to the Purnace Supervisor, was where the difficulties had mainly occurred: ninety per cent of the job was the same, but each shift supervisor had a different way of doing the last ten per cent. Once a Pakistani had been trained to do a job one way, he claimed, they objected to doing it another, and it was very difficult to get them to change their methods.

Nevertheless, managers in five other firms ${ }^{1}$ claimed that Asian workers could be transferred between different jobs. Furthermore, the Personnel Manager of Castle Iron Co. etated that although Aslan workers in general were less flexible than white workers, Pakistanis had been found more adaptable than the others.

Data concerning the flexibility of Weat Indian workers were obtalned in four firms. ${ }^{2}$ All four respondents stated that they could be transferred from one job to another and three 3 claimed that they would not resent being transferred. In Hamilton Engineering Co., according to the Labour Officer, oniy

1. Firms 16, 18, 19, 22, 23.
2. Firms 19, 20, 21, 22.
3. Firms 12, 20, 21.


Pive of the firm's fourteen West Indian workers had never been employed on more than one job. The respondent claimed, moreover, that they had been "quite happy" to accept a different job, ever. when they were given one at a lower rate of pay, because of redundancy. ${ }^{1}$ Similarly, the Works Director of Torrington Cutlers Itd. stated that West Indians seemed just to take any job they were given. "The Personnel officer of Grange Graphite Co., however, thought that there inight be some resentment if the West Indian thought that being transferred was a reflection on his skill.

In the questionnaire survey, only one question was included on flexibility in order to economise space. Respondents were simply asked to state whether they had found the various coloured groups to be "more or less flexible (i.e. capable of being put on different jobs) than British workers, or about the same." The following answers were obtained.

Teble 17 : Menagerial Assessments of the Flexibility of Coloured Workers (Questionnaire Survey)

\begin{tabular}{|l|c|c|c|c|}
\hline \hline \multirow{4}{*}{ West Indians } & $\begin{array}{c}\text { Less Flexible than } \\
\text { British Workers } \\
\text { (percentage) }\end{array}$ & $\begin{array}{c}\text { About the sare as } \\
\text { British Workers } \\
\text { (percentage) }\end{array}$ & $\begin{array}{c}\text { Nore Flexible than } \\
\text { British Workers } \\
\text { (percentage) }\end{array}$ & $\begin{array}{c}\text { No. of } \\
\text { Firms } \\
\text { Responding }\end{array}$ \\
\cline { 2 - 5 } Pakistanis & 59 & 33 & 8 & 39 \\
Indians & 65 & 32 & 3 & 32 \\
Arabs & 57 & 43 & - & 14 \\
Africans & 77 & 23 & - & 13 \\
\hline
\end{tabular}

1. Hamilton Engineering Co. carried out several different types of industry on the same premises, so it was rare for a lapse in trade to occur in all departments at the same time. Instead of making workers redundant, therefore, the firm's policy was to transfer workers from departments where work was slack to others where there were vacancies. However, it was not always possible to transfer at the same level, so this sometimes involved accepting lower wages. 
It will be seen that over half the respondents thought that coloured workers were less flexible than white workers and that, in general, Asian workers were regaraed as being slightly less flexible than West Indians.

\section{Supervision}

In the questionnaire survey, managers were asked whether they had found that coloured workers required more supervision than white workers, less supervision or about the same amount. Their responses are presented in Table 18.

\begin{tabular}{|c|c|c|c|c|}
\hline Table 18 : & $\begin{array}{l}\text { Managerial Asces } \\
\text { Workers (Ques }\end{array}$ & $\begin{array}{l}\text { ent of the supe } \\
\text { onnaire survey) }\end{array}$ & visory Requiretent & s of coloured \\
\hline & $\begin{array}{l}\text { Less Supervision } \\
\text { than White } \\
\text { Workers } \\
\text { (percentage) }\end{array}$ & $\begin{array}{l}\text { About tice sane } \\
\text { Supervision as } \\
\text { White Workers } \\
\text { (percentage) }\end{array}$ & $\begin{array}{l}\text { Hore Supervision } \\
\text { than White } \\
\text { Workers } \\
\text { (percentage) }\end{array}$ & $\begin{array}{l}\text { 10. of Firas } \\
\text { Responding } \\
\text { - }\end{array}$ \\
\hline West Indians & 2 & 42 & 56 & 41 \\
\hline Pakistanis & 6 & 35 & 59 & 34 \\
\hline Indians & 0 & 50 & 50 & 16 \\
\hline Axabs & 0 & 44 & 56 & 13 \\
\hline Africans & 0 & 44 & 56 & 13 \\
\hline
\end{tabular}

It will be seen that, in a little over 50 per cent of cases, coloured workers were thought to require more supervision than white workers, and rarely were they thought to require less. The writer would suggest, however, that different factors are involved in these assessments as far as Negroes (West Indians and Africans) and Asian workers are concerned. 
Broadly speaking, the supervisor in industry has two main functions: firstly, to give instructions concerning the work to be done, and secondly, to ensure that the worker maintains a satisfactory level of performance. For the instructions to be carried out, two things are necessary: firstly, the worker must be able to understand the instructions, and secondly, he must be prepared to carry them out. Thus the supervision of coloured workers (or any nationality of worker, for that matter) is likely to be more difficult:

a) If the workers cannot understand instructions,

b) if the workers are not amenable to discipline, and

c) If the workers do not maintain a satisfactory level of performance without constant supervision.

In relation to the latter question, much of the ground has already been covered in the section on managerial beliefs concerning the diligence of coloured workers. It was concluded that, in general, managers tended to belleve that Asians were more hard working than West Indlans. It would seem to follow, therefore, that they would also be regarded as requiring less supervision in this respect. One further point requires attention, however. Some managers suggested that Asian workers often lacked the initiative to proceed to other tasks when they had finished the one on which they were working, and therefore required closer supervision.

If anything goes wrong or they run out of work, the Aslatics just stand there - they don't tell anyone. The West Indians are more likely to do something about it.

(Personnel officer, Grange Graphite Co.) 
They don't appear to exercise any initiative. They will do the job they are told to, but they will not go on to anything else when they've finished 1t.

(Production Services Manager, Blackford Rolling Mills)

Coloured workers (mainly Indians in this firm) need a lot more supervision, especially on day work - they can't think for themselves.

(Personnel Manager, Muirhead Foundry)

Nevertheless, certain reservations need to be made in respect of the above bellef concerning Asian workers. Firstly, it was only mentioned in the above three firms. Secondly, it is only relevant to certain jobs, princlpally day work. It would apply to a much lesser degree in the case of piece work or team work. Thirdly, some managers were of the opposite opinion with regard to Aslan workers. For example, in Polton Rolling Mills it was stated that Asian workers required very little supervision and in Stainless Steel Ltd. the General Manager said that, once they had mastered the job, Asian workers could be left to it. And fourthly, one manager expressed the same belief about West Indian workers. The Labour Officer of Hamilton Engineering Co. stated that the majority of West Indians needed to be "chased up" after each job had been finished on routine work.

We now turn to the question of communication. Language difficulties with respect to supervision were mentioned in several firms ${ }^{1}$ in both interview surveys. Some examples are 1. Firms 1, 8, 10, 13, 14, 15, 16, 17, 18, 19, 23, 24, 25, 26. 
as follows:

Pakistanis have to be spoon-fed. All their booking has to be done for them. Giving orders is a more complicated business. For example, there are many different sizes and shapes of tool blade and handle. Instead of merely saying, "Put such and such a blade on such and such a handle", the supervisor must take the coloured worker to the pile of blades, show him the relevant pile of handles, and then demonstrate that he wants this handle fastening to this blade. Even then, mistakes are made, and a coloured worker will happily go on fastening the wrong handle to a blade, when, apart from the fact that they each have three holes through which he can put rivets, they obviously don't fit.

(Labour Manager, Edge Tools Itd.)

The main difficulty is with language. They say they understand an order, $\mathrm{hix}^{t}$, then when you go and check what they are doing you find that they have got it all wrong.

(Furnace Supervisor, Ridgeway Steel Co.)

The Personnel office selects those (coloured workers) who can speak Anglish. It is the foremen who have to give the orders and this can lead to difficulties if there are workmen who cannot speak English. They can always say "Me no understandee" if anything goes wrong •

(Personnel Officer, Components Itd.)

At Blackford Rolling Mills communication difficulties had been experienced, not so much with supervision of work, but with 
administrative details such as National Insurance and Government Graduated Pensions, and with the settling of domestic difficulties. 1

In some firms, it was suggested that the supervision of Asian workers became less difficult, the longer they worked for the firm.

Initially, they require more supervision. In the later stages, they adapt themselves pretty similarly to the white worker in the same grades, but still finding language a difficulty.

(Personnel Officer, Quality Steel Co.)

In the early days they were more difficult to supervise. Now we've had the experience, it's easy. In the early days we used to have difficulty with language. We used sign language and we sent them to schools in their spare time to learn English. We don't notice the language difficulty now: we understand them better and they understand us better.

(Personnel Manager, Sterling Metal Co.)

Finally, at Castle Iron Co. It was stated that no difficulties with language had been experienced even when coloured

1. Another administrative difficulty occasionally mentioned where large numbers of Asian workers were employed was the fact that many of them had the same name. Bradfield Foundry, for instance, employed about fifty Indians, forty-two of whom were called "Singh". This difficulty was overcome by referring to the men by their clock numbers, e.g., "181 Singh" or "42 Singh". Simllarly, at Sovereign Steel Works the Labour Manager stated: "We have a lot of trouble with names. They often have the same name. I had to take a phone call for a coloured man to say that a relation was in hospital. We had six men all of the same name working for us, none of whom lived at the address given." 
workers were first employed. The Personnel Manager was asked whether any initial difficulties had been encountered in the employment of coloured workers. He replied:

Iike the language difficulty, you mean? No, not really. We rapidly picked up a few words and we found we could make ourselves understood. We had a bloke who had been in India and could speak a bit of Hindi who heiped us with this. Then gradually these blokes (the Asian workers) picked up English.

However, the above case was exceptional, and even here language difficulties were encountered in the training of Asian workers. In the case of the West Indians, of course, the question of language hardy arises. There were occasional complaints concerning the difficulty of understanding dialects, but, in the main, the West Indians' ability to speak English was regarded as one of their major advantages over the Asian group. The West Indians' attitude towards supervision, on the other hand, was often regarded as one of their major disadvantages. Three firms (Bradfield Foundry, Westwood Foundry and Omega Metals), had ceased to employ West Indians as a matter of policy, and in each case, an adverse assessment of their amenability to discipline had been a contributing factor.

The Labour Manager of Westwood Foundry stated that West Indians had "caused trouble with their arrogance" and had "wanted quite a bit of their own way." The Indian, he claimed, was proud of his heritage whereas the West Indian wanted to be "bleached" and felt strongly about the colour bar. Similarly, 
the Works Manager of Omega Metals Ltd. stated:

They are colour conscious from the word go and have a chip on their shoulder from the word go. No matter how you try to nurse them along it comes out.

At Bradfield Foundry, the Technical Controller stated that, as opposed to Indians who did as they were told, West Indians tended to be "barrack-room lawyers." The Production Manager in the same firm stated:

They are truculant and troublesome. They expect preferential treatment. If you do not employ them, they say it is because of the colour of their skin. If you give them a job no-one else wants, they say they are being picked on because they are coloured. But someone has to do these jobs and they came last, so what do they expect.

The general attitude towards West Indians in this firm was summed up by a Foreman who said: "If there was any trouble, they would say 'colour bar', but if there was, it was of their own making."1

In Brierley Metal Works the Labour Manager's attitude

1. The West Indians' claim that this firm operated a colour bar is understandable perhaps, but somewhat inaccurate. As over $50 \%$ of the firm's employees were Asian immigrants, "shade bar" would be a more apt term. According to the Production Manager, the Gateman tells West Indians, when they come for jobs, that there are no vacancies. He continued: "Then the Jamaican will say we have a colour bar and we will not employ him because of the colour of his skin. That's a laugh - they say outside the works that all the white men here have their own football sweep - all twelve of them." 
towards West Indians was somewhat more favourable: he thought that they were too highly educated for labouring jobs. Nevertheless, very few West Indians were employed. The Labour Manager stated:

Employing Jamaicans doesn't work out. They soon want to be boss and they can't all be boss.

In Polton Rolling M1lls, where there were also very few West Indian workers, the Labour Officer claimed that this state of affairs had occurred by chance - it was just that Arabs and Pakistanis had been the ones who had applied for jobs. On the other hand, one of the Departmental Managers stated that he would not accept West Indians or Somalis because they were, he claimed, "bone ldle and arrogant."

Even in some of the firms in which West Indians were employed, there were complaints concerning a "chip on the shoulder" att1tude.

West Indians have a chip on their shoulder about a colour bar which does not exist. 1

(Personnel Manager, Central Glass Works )

On the average, West Indians are a little more difficult to supervise because you do have to tread on

1. In this case, the West Indians' claim that there was a colour bar had considerable justification. According to the Personnel Manager, Aslan workers were excluded and the West Indians' employment and occupational levels were limited as a result of restrictions on the part of the white workers. Under these circumstances, it is difficult to see how he could maintain that the colour bar about which the West Indlans were concerned did not exist. Nevertheless, he did so. 
thin ice. Supervisors have found that if they have to reprimand a coloured worker, they tend to claim that they are being picked on because of their colour.

(Labour Officer, Hamilton Fing ineering Co.)

They tend to have a man-sized chip on their shoulder. Our greatest problem is with West Indians who look for insults where there aren't any.

(Personnel officer, Grange Graphite Co.)

In Drop Forgings Ltd. the "chip on the shoulder attitude" was also mentioned, but here it was apparently regarded as the exception rather than the rule. The Personnel Manager stated:

We have had isolated spots of trouble with coloured workers: one sat on a box and smoked cigars all day and thought he should be paid for it. We sometimes get a Jamaican with a chip on his shoulder and we have to get rid of him. He then turns round and claims he is the victim of a colour bar. During the late'fifties, when there was a boom in the industry, a Jamaican would turn down a job at $\$ 12100$. to $\$ 13$ because it wasn't enough money. They would turn down jobs that white men were doing.

However, the respondent concluded:

There has been some trouble, but you get the same kind of thing with whites. We know housing conditions are sometimes bad, but it doesn't seem to reflect on their attitude at work. 
In another firm, it was suggested that West Indians had tended to become less amenable to discipline as the immigration to Britain had progressed. The Personnel Director of Precision Engineers Ltd. claimed that the better type of immigrant had come first. They were grateful just to have employment and the helght of their ambition had been to own a bicycle - usually a very fancy machine with lots of accessories. The later people, he sald, were not so grateful: they were more aggressive and arrogant. 1

Conversely, in Edge Tools, an initially adverse assessment of the West Indians' amenability to discipline eventually gave way to a much more favourable attitude towards them. The Labour Manager stated:

They had a chip on their shoulder at first they argued with the foreman and perhaps were awkward - but now they have got to know us better and some of them are quite pleasant.

In only two cases was it said that West Indians were more amenable to discipline than white workers. The Personnel Manager of Pentland Alloys stated:

$$
\begin{aligned}
& \text { I'm told by the foremen that they are no } \\
& \text { trouble at all. In fact they are less } \\
& \text { difficult - less argumentative. Still you } \\
& \text { must take into account the fact that they } \\
& \text { are happy to have a job. }
\end{aligned}
$$

Similarly, in Torrington Cutlers, the Works Director stated: 
Within the limitations of their activity, they are a little easier to supervise. They are a little less worried about working conditions. On the type of job they do, where they just do as they are told, they will go on doing as they are told and are less likely to swing the lead. However, they don't look for work.

In the latter firm, however, another member of management d1sagreed with the Works Director's assessment. He claimed that the West Indians not only did not look for work, but actively avoided 1t. The respondent stated:

They don't like work, apart from in the Silversmith section. They are terribly lackadaisical and if they are not watched all the time, they disappear. I went into the storeroom once and found three of them sitting in the dark, two asleep and one awake. Their supervisor has a terrible time with them. He sometimes has a lorry to unload in a hurry: the big lorries can't get into the yard so they have to stay in the lane blocking the road until they are unloaded. Then he can't find his coloured workers to do the job so he has to make do with what he's got. And they don't like being told what to do: they resent being given orders. I don't know why they have put up with them for so long.

Finally, in City Transport it was stated that West Indians were more amenable to discipline than Pakistanis. The Personnel Manager stated that West Indians were "easier to get along w1th" than Pakistanis, the latter tending to be more aloof. Pakistanis, 
the respondent claimed, were more argumentative than West Indians they would not take 'no' for an answer. It must be remembered, however, that as this firm was a 'bus company and the majority of coloured workers were conductors, the supervisory position was quite different from that found in the normal industrial concern. Presumably, therefore, the respondent's attitude was hased upon his experience of the behaviour of coloured employees in the Personnel Office.

The majorlty of managers in the interview surveys found Asian workers very amenable to discipline. As we have already noted, one manager described them as "more anxious to please" than the British worker and another stated that they would "do. as they were told until the cows came home." Other comments were as follows:

The Indian soon learns and is amenable to discipline.

(Labour Officer, Westwood Foundry)

The Pakistanis are a very impassive people. I have never seen one of them get het up about anything or lose his temper.

(Labour Manager, Edge Tools Ltd.)

Pakistanis are more polite than the British worker.

(Works Manager, Omega Metals Ltd.)

West Indlans are more difficult to supervise. With Asiatics, it's easy enough. If you say "Run round the car park," they will run round the car park all day.

(Personnel Officer, Grange Graphite Co.) 
Pakistanis are more amenable to discipline than white workers. They do as they are told, if they understand, more quickly than white workers.

(Personnel Manager, Ridgeway Steel Co.)

I think they are easier (to supervise). It may be that we have a good crowd here - they were hand picked. They will work all hours of the day if you ask them. They sometimes bring in a nephew or a brother if you need more labour.

(Labour Officer, Polton Rolling Mills.)

In the Grange Graphite Co. amenability to discipline was apparently the key determinant of managerial preferences with regard to the different coloured groups. The Personnel officer stated that West Indians tended to be more skilled than Asian workers, were easier to train and, because of their superior physique, capable of working much harder. Nevertheless, the respondent said that he would rather employ Asian workers because they were more tractable and easy to control.

Some evidence that Pakistani workers were regarded as being more amenable to discipline than West Indians was also found in the questionnaire survey (see Table 19). However, this was not so in the case of other Asian groups and, in contrast to the interview surveys, few managers reported that West Indians were less amenable to discipline than white workers. Of the two sets of data, studies reported in the literature provide more support for the interview survey findings. Banton (1955) ard Patterson (1963) for example, note the existence 


\begin{tabular}{|c|c|c|c|c|}
\hline & $\begin{array}{l}\text { Less Amenavie to } \\
\text { Discipline than } \\
\text { White Workers } \\
\text { (percentage) }\end{array}$ & $\begin{array}{l}\text { About the same as } \\
\text { White Workers } \\
\text { (percentage) }\end{array}$ & $\begin{array}{l}\text { Nore Arenable to } \\
\text { Discipline than } \\
\text { White Workers } \\
\text { (Percentage) }\end{array}$ & $\begin{array}{l}\text { No. of Firms } \\
\text { Responding }\end{array}$ \\
\hline West Indians & 9 & 62 & 29 & 45 \\
\hline Pakistanis & 9 & 51 & 40 & 35 \\
\hline Indians & 27 & 61 & 22 & 18 \\
\hline Arabs & 23 & 67 & 20 & 15 \\
\hline Africans & 13 & 60 & 27 & 15 \\
\hline
\end{tabular}

of a "chip on the shoulder" attitude amongst many West Indians, and Banton comments upon the greater docility of Asian workers. It seems likely, therefore, that the interview survey data presents a more reliable picture of the situation, but the further possibility that the apparently anomalous results of the questionnaire survey reflect a change in the behaviour of West Indian workers or in the attitude of management cannot be ruled out on the basis of the present evidence.

\section{Methods Used in the Supervision of Asian Workers}

As was the case with training, several methods were evolved to overcome the language difficulties involved in the supervision of non English-speaking Asian workers. ${ }^{1}$ Sometimes the same

1. As we have already noted, some firms avoided the problem altogether by not employing Asian workers or only employing those whose English was adequate. However, we are not concerned with these cases here, but with those in which non English-speaking Asian workers were employed. 
methods were used in both training and supervision, but the emphasis placed on these methods were not necessarily the same in both spheres. Sign language, for example, was commonly used in training, but more rarely encountered in supervision. The reason for this, the writer would suggest, is the fact that whereas training is a relatively short term matter, supervision is a permanent necessity. Training may take longer when sign language is employed, but if the job is capable of being taught by sign language, then it is possible for the Asian worker eventually to become proficient. On the other hand, if only sign language is used, supervisory efficiency is likely to be permanently impaired. ${ }^{1}$ For this reason, other methods have tended to be evolved.

In two firms, Stainless Steel Ltd, and Castle Iron Co., supervisors had learnt "a few words" of the language of the Asian workers concerned. ${ }^{2}$ Conversely, in Sterling Metal Co. an attempt was made to teach the coloured workers English. This, however, was the only f1rm in which such an attempt was made in a systematic manner, although it was stated in other firms (e.g. Components Itd. and Tool Steel Ltd.) that individual white workers would sometimes help those Asian immigrants who wished to learn English. Both these methods suffer from the same drawback. A vocabulary of a few words in the language concerned may be of some help, but of necessity it is of limited value except

1. See, for example, Edge Tools Ltd. (page 285)

2. The General Manager of Stainless Steel Itd. stated: "The supervisors have learnt a few words in their language such as, 'up', 'down', 'left', 'right', 'stop', 'go'. 
for the simplest of orders. Becoming fully conversant with the language, on the other hand, is a laborious and time consuming matter, a factor which has no doubt deterred most firms from employing either of the above methods.

A more common method of solving language difficulties in supervision was job placement; that is, the placing of coloured workers in jobs in which the supervisory requirements were minimal. On some piece work jobs, e.g. moulding in Bradfield Foundry, the necessity for order giving was virtually nonexistent. The workers concerned were on the same job each day and, providing the necessary raw materials were available, could carry on doing their job without needing to communicate with anyone, supervisors or other workmen. The fact that they were on piece work also meant that they were highly motivated and therefore it was not necessary for the Foreman to be present in order to maintain a satisfactory level of performance. The Foreman in question spent comparatively little of his time within sight of the workers and only rarely, during my visits to the firm, communicated with any of them.

Similarly, the Asian workers employed as members of rolling teams required little or no supervision. The machine was set by the roller (who was invariably British) and once the process had been begun, the Asian worker (and other members of the team) merely had to feed the strip back and forth through the rollers until it was the required size and shape. Thus no communication was required during the operation except perhaps for a sign to start and a sign to stop. Again, supervision in 
order to maintain a satisfactory level of performance was not necessary elther; the pace was set by the head roller and by the machine. In Steel Bars Itd., for example, the Works Manager said:

There is no supervision involved. They are part of a team. The roller is responsible for his men.

In some firms it was suggested that Asian workers were easier to supervise in a group rather than individually. For example:

Language is a problem. We had to sack a Pakistani last year because we could not understand him and he could not understand us. They seem terribly thick, but this is largely because they don't speak the language. However, we can deal with them in teams.

(Personnel Manager, Ridgeway Steel Co.)

They seem to work better in a team. By a team, I mean a team of their own people.

(Production Services Manager, Blackford Rolling Mills, re. Pakistanis and Arabs)

The obvious advantage of employing Asian workers in a group is that any order has to be "got across" only once. Were they on different jobs throughout the works, on the other hand, the language barrier would have to be surmounted with each individual worker. In addition, where Aslan workers are in groups, the order has to be "got across" to only one worker (the most alert or the one who has least difficulty with language) and he will translate for the rest. From this, it is but a short step to 
using the 'go-between' system.

The use of b1-lingual 'go-betweens' as interpreters was perhaps the most common method of overcoming the language problem where large numbers of Asian workers were employed. Examples are as follows:

Often the Pakistanis cannot speak English, and orders have to be given through the few who can. Usually there is one Pakistani per shop who can speak Bnglish and he is used as a 'go-between'. New Pakistani employees tend to live in one of three houses in the district owned by one or other of the 'go-betweens'.

(Personnel Director, Precision Bngineers Ltd.)

The coloured workers (mainly Indians) cannot speak English, so one or two interpreters are used.

(Personnel Manager, Muirhead Boundry)

Because of the language difficulty, we used one of the Arabs to interpret for the rest who have only a smattering of English.

(Works Manager, Annerley Iron Foundry)

The firm used to use a Somali as an interpreter. He also used to help the police. He has just left the firm to go back to Somaliland. He was the chief of the Somalis in (the city). He sometines wore the full regalia of a chief for example, during the independence celebration.

(Personnel Manager, Sovereign Steel Works)

In Ridgeway Steel Co., according to the Personnel Manager, the first coloured worker employed by the firm had become 
"a kind of unofficial labour officer." He had selected the Pakistani workers who were later employed and had "sorted out their problems" at the shop-floor level.

In the above cases, the 'go-betweens' had no official standing other than that of an ordinary workman. In two firms, however, 'go-betweens' had been promoted to the position of chargehand. At Sterling Metal Co. most of the early employees had been Somalis. The Personnel Manager stated:

The first one was an admirable man, a very good worker. He could speak good English and could always be relled upon to introduce good men. He wouldn't let the firm down by bringing in people who weren't much good. He eventually became a chargehand over his own people in the boiler house.

Similarly, the Pakistanis in Omega Metals Ltd. were supervised by a chargehand of their own nationality. Although technically speaking a chargehand, however, the man's position was more that of an officially recognised 'go-between', in that his authority extended to all the Pakistani employees irrespective of their jobs, but not to any of the British workers nor to the one West Indian employed by the firm. Nevertheless, as the only man in the works who could communicate verbally with both the Pakistani and the British members of the firm, he was in an extremely powerful position. All orders from management to the Pakistanis had to go through him, as had all communications from them to management. According to the Works Manager, all hiring of Pakistani workmen was left in his hands: management 
simply told him how many men were required and he supplied them. He also undertook most of the training of the Pakistanis, even though their jobs might be quite dissimilar from his own. Bight out of the ten Pakistanis I interviewed, including three shotblasters, a fork-lift truck operator and a painter, stated that the chargehand had taught them their jobs.

Management seemed to be highly satisfied with this arrangement and not without reason from their point of view. ${ }^{1}$ By the employment of a bi-lingual chargehand, the language difficulties in training and supervision of Asian workers so often found in other firms, had largely been avoided. The chargehand himself stated that it was because of the language difficulty that Pakistanis only obtained labouring jobs in the big firms. He stated:

They can do every (i.e. any) job, but they cannot learn because of language. If I tell them, they can understand and they can do the job.

How far the success of this system resulted from the mere

1. The two British supervisors employed by the firm were, however, less satisfied with the situation. Both found language a difficulty and both thought that coloured workers required more supervision. The Works Engineer sald that the language barrier had caused a lot of trouble: as a result of not understanding orders, the Pakistanis "did things they shouldn't and sometimes smashed things up." The Foreman said that Pakistanis required a little more supervision because they had never worked in industry before, but the longer they had been in the country the less supervision they needed. He also stated that it was easier to give orders to Pakistanis, providing one could make oneself understood. One of the white workers also claimed that the language barrier caused difficulties: "If you want anything done, you go to their chargehand and he arranges it. The trouble is, you keep having to go to him." Another white worker claimed that the chargehand used the fact that he was the only Pakistani who could speak Fnglish to his own advantage: he would not bring in anyone who could speak English. 
fact that the chargehand was bi-lingual and how far it was due to the personality and capabilities of the chargehand, it is difficult to say. The Works Manager spoke very highly of him both as a workman (he was a painter by trade, and 'red-hot' at It according to the respondent) and as a supervisor. As an example of his efficiency in the latter capacity, the Works Manager told me of an occasion when the firm had needed four men to do some contract work at a large steel works. The chargehand was simply informed that four men were required, that they would need to know shot-blasting, and that they would need lodgings near the steel works. The chargehand got the men, had them trained within a month, and when asked what he had done about accommodation, he informed the Works Manager that he had obtained lodgings for them across the road from the firm concerned.

The chargehand would appear to have made himself indispensable to the firm. When he wanted to go back to Pakistan for a holiday, the firm not only granted him three months leave, but paid his air fare there and back. Furthermore, whilst he was away, there was considerable unrest amongst the Pakistani workmen. According to the Works Manager, they split up into two groups which were "practically at war with one another." When the chargehand returned, he was told of the situation. He immediately lined all the men up and, in the words of the Works Manager, "played hell with them." Apparently, what he told them was, in effect, that there were plenty of men who would be glad to work there, and that if they didn't behave, he would get rid of 
the lot of them and get in some new men who would. The Works Manager said that he had never seen a supervisor play hell with workers to such an extent before. There had been no trouble since.

The Works Manager stated that the chargehand was also useful to the firm in other respects. On one occasion, for example, management wanted a rate cut to provide more incentive. They simply told the chargehand that the rate was to be cut and "that was that." They did not exploit the coloured workers, the Works Manager quickly explained. They couldn't even if they wanted to: it would have been possible at one time, but it wasn't any more, which was a good thing.

In spite of the apparent success of this method, Omega Metals and Sterling Metal Co. were the only firms in the interview surveys in which 'go-betweens' had been given official supervisory posts. In the other firms, the possibility of using Asian supervisors was hardy even mentioned. In one firm, the respondent merely stated:

We have never contemplated supervisory jobs for these people.

(Personnel Officer, Grange Graphite Co.)

In two firms, however, respondents explained why they thought it would be unwise to promote Asian workers to such positions. In one case, it was stated that promotion was open to all workers, irrespective of nationality, but only as far as skilled jobs and no further. The respondent did not believe in promoting Asian workers to supervisory posts or even giving them any 
knowledge of supervisory methods. The reason given was that bribery and corruption had been rife in their own countries for hundreds of years and there would be a grave danger of an Asian supervisor receiving gifts for services rendered. 1

In the other firm, Ridgeway Steel Co., a Shop Manager stated that the firm had once tried to train a Pakj.stani as a supervisor, but it had been a mistake. The man had been "all on the management's side", and had treated the Pakistani labourers under him "like dirt". It would have been quite a problem, the respondent stated, but fortunately the man in question had gone back to Pakistan. Since then, he had drawn the line at promoting Pakistanis to supervisory positions. The respondent also stated that there had been muours that one of the Pakistanis had been taking a "rake off" from the rest, but management had been unable to prove anything.

In some firms not even unofficial 'go-betweens' were used. A variety of reasons were given. In Components Ltd. the Personnel officer stated that the interpreter system was not used because it would have necessitated the segregation of Asian workers into their own work groups, which was against the

1. In Omega Metals the chargehand is, of course, in an ideal position for taking 'kick backs'. The Works Manager stated, however, that he had suggested to the chargehand that he was taking graft and the man had denied it. He told the respondent that he owned two houses and charged the boarders who worked at the firm only fifteen shillings per week, all the boarders putting something in a common pool for meals. He claimed that he had no need to take graft because he had no intention of going back to Pakistan. 
flrm's policy. In Major Castings Ltd. the Personnel Manager stated :

There is a leaning towards Jamalcans because of language. The Ministry of Labour suggested that we should use an interpreter to overcome the language problem, but what happens if the interpreter leaves? You are left with twenty to thirty people, none of whom can speak Bnglish.

In Grange Graph1te Co. the Personnel Officer said that they had never used unofficial 'go-betweens' because they would not want anyone usurping the supervisor's position. It would appear that one of the Asian immigrants had attempted to act as a 'go-between' in this firm, but had been stopped. The respondent stated:

You occasionally get one Asiatic who can understand the language who then capitalises on the situation. We had one who set himself up as the Arab Shop Steward. We put a stop to that. We pointed out that if we had a shop steward to represent every different nationality we employ, we would have more shop stewards than members of staff and we weren't having that. 1

1. The respondent also stated that there had been cases of Asian employees taking bribes from their fellow countrymen. "We have had trouble with ten-percenters - people who take a cut from their work mates. One man brought in eleven men and took $\$ 1$ a week from them. We had to stop h1m. We couldn't reason with $\mathrm{h} 1 \mathrm{~m}$; he thought $1 \mathrm{t}$ was natural. We had to threaten him with the sack, but he didn't see why. He seemed to think I was a lucky fellow because I was getting a pound a week from 625 men. I have also had offers from West Ind1ans. One West Indian landlord offered me a cut if I would get work for the men in his house. But it seemed more vicious with the West Indians - more like gangsterism. With the Aslatics, it just appeared to be the natural thing to do." 
Before leaving the subject of 'go-betweens', it is worth noting that they were sometimes used for purposes other than supervision. In Omega Metals, for example, the duties of the Paklstani chargehand exceeded those usually carried out by the industrial supervisor in that he also obtained workers for the firm when they were needed. Managerial policy towards the recruitment of workers in this manner varied somewhat in the firms visited during the interview surveys. In Precision Engineers Ltd., for example, 'go-betweens' were used in order to facilitate order giving, but not for recruitment purposes. The Training officer sald that all labour requirements were obtained through the Labour Exchange: there was no hiring on the job. He stated:

\section{If we didn't use the Labour Exchange, there would be one long queue at the works gate. The Labour Exchange method saves their time and ours.}

In Edge Tools, on the other hand, 'go-betweens' were not used for order giving, but were used for recruitment. The Labour Manager stated that it was easier to obtain new employees by asking a workman to bring in a friend than by obtaining them from the Ministry of Labour. The reason was that the friends were helped by workmen already employed by the firm whereas those from the Ministry of Labour were not. The respondent stated, however, that the drawback to this method was that it lent 1 tself to bribery. The firm had investigated rumours of bribery in the factory, had threatened some people thought to be responsible and begun employing coloured workers through the 
Employment Exchange. This, however, had not worked (presumably for the reason mentioned above) and the firm had gone back to employing friends of existing employees.

The recruitment of Asian workers through friends and relatives already employed by the firm was also mentioned in Major Castings Ltd., Annerley Iron Foundry, Polton Rolling Mills and Castle Iron Co.' In Steel Bars Ltd. a 'go-between' was also used for recruiting purposes, but in this case the man did not h1mself work for the firm. The Works Director stated that they had a contact man, an English-speaking Arab, who brought men in when they were needed. A foreman in the same firm suggested that this method of recrultment was one of the reasons why the employment of Arab workers had been so successful. He stated:

It's like th1s, if they're no good to us we don't keep them. We told their "father" - he's the bloke who gets them their jobs (he doesn't work himself) - that we won't have the bad types. So he doesn't send the bad ones down: he knows we won't have them. So maybe these places that you hear about that have trouble aren't as selective as we are.

In both Ham1lton Engineering Co, and Leigham Cannery, it was reported that there has been cases of English-speaking

1. Th1s method was also used for the recruitment of West Indian workers in Hamilton Engineering Co. The Labour Officer stated: "When we are short of men, we contact one of our existing employees who brings along some applicants." 
Pakistanis bringing round several of their fellow countrymen in an attempt to obtain jobs for them. In neither firm had coloured workers been employed in this way, but in Leeds it appears that a formally organised Employment Agency for Asian workers has been set up. The following report appeared in The Guardian for 3rd February, 1964.

The man who sells jobs to immigrants

The Commonwealth People's Bmployment Agency (Mohammed Abdul Aziz, director) has been founded in Leeds to find and seil jobs to immigrants. According to his forms, Mr. Aziz charges immigrants $\$ 12$ for this service. "I have not yet charged more than $\$ 10$ a head," he said yesterday. "I am very generous, you know. I feel for these people. At the same time, I feel for British industrial supremacy." Anyone who has seen unemployed Pakistanis trailing hopelessly from factory to factory could not help sharing his feelings for them. They are often 1lliterate and have little or no English. Mr. Aziz, on the other hand, is resourceful, businesslike and articulate. Using his home in Abbot View, Armley, as an office, he sends forth messages to industriallsts declaring his readiness "to throw myself heart and soul in providing the employers with hard working and punctual workers absolutely free of cost." It is this charging of the workers instead of the employer that makes Mr. Aziz's agency so unusual in an area which has full employment. A man who is not only unskilled, but also a coloured llliterate immigrant soon finds himself in a buyer's market 
for labour. Or, as Mr. Azlz puts it: "If I charged a fee to employers they would say: 'Look Mr. Aziz, I can get labour from my factory gate. Why should I take it from you?'" Mr. Aziz says he wants to see immigrants getting Jobs "through proper discipline and manners", rather than being picked from the factory gate irrespective of their merits. His method, he claims, also eliminates the danger of such "irregularities" as an immigrant being obliged to bribe a foreman to get a job. And he makes sure that his Commonwealth clients are equipped with proper cards, or have applied to the Ministry of National Insurance for them.

Finally, it is interesting to note that in several firms 'go-betweens' owned houses in which their fellow workers lived. This was reported in Precision Engineers and Omega Metals, as we have already noted, and had also been the case in Stainless Steel Ltd. In the latter firm, the General Manager stated:

The coloured workers are confined to the Foundry and Forge mainly, but about six years ago we had one bloke, an Indian, acting as furnaceman. He was very intelligent, the ringleader of the coloured people who worked here. He bought himself a house and sub-let it to his fellow countrymen.

Similarly, a Pakistan interviewed in Ridgeway Steel Co. stated that he owned a house and had recently obtained a job with the firm for one of his lodgers. This would suggest that the 'gobetween' in industry may tend also to be a leader in the community, 
and the fact that the interpreter in Sovereign Steel Works was said to be the leader of the Somalis in the district and the contact man in Steel Bars Ltd. was referred to as the "father" of the Arabs, lends some support to this conclusion.

Thus, to summarise, the Asian 'go-between' is in an extremely powerful position as far as his fellow countrymen are concerned. Often he is the sole, or at least one of the very few, representatives of management to these workers. He is in a position, if he wishes, to claim more power than he actually has because it would be difficult for his non English-speaking work mates to check on the validity of his claims. In addition, the 'go-between' who has a lodging house in which his fellow workers live may use his authority in one sphere to support his authority. in another. There is very little, therefore, to prevent him from abusing his power, for instance by accepting bribes for obtaining jobs or simply by being autocratic, and the indications are that this sometimes does happen.

As far as the firm is concerned, management is lert in the position of being able to treat the Asian worker as an "economic man" - that is, controllable by the simple application of reward and punishment - to a much greater extent than is possible with British workers. There is very little the Asian workers can do about this, since his one representative is likely, through self-interest, to be on the side of management. It must be said, however, that most nanagements do not appear to take full advantage of this situation, although there are, of course, exceptions, one of which will be examined in the next chapter. 


\section{Summary}

As was the case with training and supervision, managerial beliefs and attitudes concerning the diligence, flexibility and supervision of coloured workers varied considerably. Thus, when making any generalisations, one must take into account the fact that there may be a considerable number of exceptions. Nevertheless, it does appear that, on the whole, Asian workers were regarded as being more hard working and more amenable to discipline than the West Indians. On the other hand, the supervision of fsian workers, apart from the question of amenability to discipline, was often made more difficult by their lack of facility with English. Various methods had been evolved, principally job placement, employment in teams and the use of bi-lingual 'go-betweens', in an attempt to overcome this problem .

For some firms, language difficulties were sufficient to deter them from employing Asian workers or at least from employing those who could not speak Inglish with a reasonable degree of fluency. In other firms, however, the Asian workers' greater diligence and amenability to discipline were regarded as more than compensating for the difficulties encountered in training and supervision. The division of opinion, we would suggest, is one reason for the tending of firms to employ either Asian workers or West Indians rather than an appreciable proportion of both groups, and for the relatively high employment level of Asian workers in the present sample of firms in spite of their lower level of skill and industrial experience. 
CHAPTER SEVEN

EQUALITY OF TREATMENT, JOB SATISFACTION

AND LABOUR TURNOVER

\section{Preliminary Summary}

Although no firm conclusions can be arawn owing to the limited data, it would appear that coloured workers received fair treatment in most firms in the interview surveys. Two major exceptions were found, however, and in one or two further cases it was suspected that management was somewhat more demanding towards coloured workers, particularly Indlans and Pakistanis. Nevertheless, job satisfaction was considerably higher amongst Aslan workers, and it is suggested that they are prepared to accept much more readily than West Indians both the jobs they are given and unequal treatment on the part of managers and supervisors. There was, however, little difference in the labour turnover rates of the two groups; in both cases, labour turnover was remarkably low. 
1. The Treatment of Coloured Workers by Managers and Supervisors

We suggested in Chapter One that, apart from employment and occupational levels, another important aspect of the work integration of coloured immigrants was the way in which they were treated by managers and supervisors. Unfortunately, this is also an area in which it is extremely difficult to obtain accurate data. It is not to be expected that managers will volunteer information concerning their 1ll-treatment of coloured workers. There seemed little point, therefore, in asking direct questions on this subject: at best one would obtain mere platitudes and at worst completely ruin the rapport. Similarly, in the interviews with coloured workers, the absence of complaints about the way in which they had been treated might mean that they had recelved fair treatment or simply that they were wary of providing information which might have unpleasant repercussions should it come to the knowledge of management.

In some cases, however, it proved possible to obtain the necessary information from the white workers and in others it was provided inadvertently by the managers themselves. Little systematic data could be collected in this way - sometimes, for example, management representatives were present during interviews with white workers - but 1t may still be of some value providing 1ts limitations are kept in mind.

In only two firms was it possible to determine, with any degree of certainty, that coloured workers were not receiving fair treatment. The first was Omega Metals Ltd. where, it will be remembered the Works Manager claimed that coloured workers were 
not exploited. His claim was not, however, supported by other white respondents. The Foreman stated that coloured workers were very much exploited by the employer, which was very bad for the British worker. He claimed that Pakistanis stood for much more pushing around by management:

There are jobs which I ask Pakistanis to do that management would not even expect men to ask British workers to do. There are one or two that get the same rates as British workers, but not many.

When asked whether the Pakistanis expected equal treatment, he replied:

They don't get it: whether they expect it or not, I don't know, but they put up with 1 t.

The Works Engineer stated:

They stand more pushing around: there's no doubt about it. They don't hold it against you though, they are not a malicious people.

However, he claimed that coloured workers recelved equal treatment, al though he did not think that they expected it.

All five white workers interviewed in this firm said that a) coloured workers stood for more pushing around, b) they did not expect equal treatment, and c) they did not get equal treatment. One white worker sald that they did the jobs noone else would do. Another, in answer to a question concerning how he felt about working with a firm which employed coloured workers, said:

It doesn't make much difference to me: or at least 
It wouldn't if they were all on the same rate. If I'm on one rate and they're on another, it's bad for us. If they (1.e. management) can get work done cheaper than us, then we get kicked out.

A third white worker, when asked how he felt about a coloured worker doing the same job as himself, replied:

I don't mind him doing the same job, but if he gets paid less money than me - and there are coloured workers doing my job and working just as hard for two shillings an hour less I can't go to the gaffer for a rise. He's got a Pakistan1 who will do the job.

The same respondent also claimed that the manager sent the Pakistani workers home "when he felt like it."

If there's no work to be done, he sends them home at any time of the day. They just do as they're told. That's why he likes them so much.

Finally, certain comments of the Works Manager himself concerning, for example, rates being cut and the chargehand "playing hell" with the Pakistanis ${ }^{1}$ provide further indications that discrimination occurred.

Thus, drawing together statements and innuendos from vartous sources, it is possible to build up a picture of the kind of treatment received by coloured workers ${ }^{2}$ in this firm:

1. See Chapter Six.

2. That 1s, the Pakistanis. None of the above comments applied to the one West Indian employed by the firm. 
firstly, they were given the worst and most menial jobs to do; secondly, they were ordered about more, both by management and the supervisors, including their own chargehand; thirdy, they were paid less than white workers on the same jobs; and fourthly, although this only came from one source, they were sent home when there was no work for them to do. This scarcely supports the Works Manager's claim that there was no discrimination.

It is worth noting, however, that management's behaviour did not appear to arise from prejudice. The Works Manager, in fact, had a very favourable attitude towards the Pakistani workers with respect to both their diligence and amenability to discipline. It may be, of course, that the prejudices were latent and did not manifest themselves because the Pakistanis behaved in the manner in which coloured workers were expected to behave. ${ }^{1}$ Nevertheless, the main causes of discrimination in this firm appeared to be economic. The second case of discriminatory treatinent, on the other hand, involving as it did not only stereotyping and sexual. jealousy but also the ability to hold contradictory beliefs without even realising it, presents an almost classical example of racial prejudice.

After interviewing the Personnel Manager of Sterling Metal Co., the writer also interviewed two Departmental Managers. In one department, the coloured workers were employed in the rolling

1. Cr. the belief of some white people in the Southern States of the U.S.A. that "the Negro is all right in his place." Prejudice therefore, is more likely to be manifested against those Negroes who step out of their "place" rather than those who remain in it. 
teams. A union representative told me that on one shift a Somali was employed as middle man - that is, third in seniority from the roller - and had white men working under him. The Shop Manager compared the coloured employees very favourably with white workers. He stated:

They're good workers. We used to have some riff-raff, but they've drifted away now. We used to have some trouble, mainly between different coloured people, but we haven't had any recently.

In the other department, the coloured workers were also Somalis, but here they were employed only as sweepers up. Immediately the manager was informed of the nature of my work, he stated that he couldn't stand coloured people, that he hated the lot of them, and that they all ought to be sent home. When asked what he had got against them, he asked me what I had got for them (implying by his tone that there could not possibly be anything in their favour). When I replied non-committally, he said that the trouble was that they were "an idle set of black bastards who sat on thelr arse all day and did nothing." They couldn't understand you when you wanted them to do something, he continued, but they were as sharp as anything when they thought they had been underpaid. The respondent told me that he had been all over the world and seen them in their own countries. They were uncivilised and dirty, and then they came over here, put on a white shirt, and started going out with white women. He stated that he could not stand the idea of coloured men and white women, but was not so averse, however, to discussing his own experiences 
with coloured women.

The Shop Manager sald that his foreman would back him up in his opinions about coloured workers. The foreman was then introduced to me and the Shop Manager then left the room to find some coloured workers. When asked how he had found the coloured workers, the foreman merely stated that they were all right for sweeping up jobs, but no use for anything else because they were not intelligent enough. However, he displayed none of the virulent prejudice of his superior.

Two Somalis were brought in to be interviewed. The first answered questions without difficulty. The second, however, was a little slow in answering: he stated that he did not understand. The Shop Manager stated that the man did understand and was deliberately pretending not to. He then tried to ellcit answers by asking the same questionsover and over, but each time shouting them louder and louder. The Somali became more and more flustered, but eventually the Shop Manager was able to ascertain that the man had ianded in London and had worked in Manchester before obtaining his present job. After the man had left, the respondent turned to me and said: "You see how evasive they are, he understood all along."

Finally, just before I left, the respondent asked me how the other Shop Manager had found the Somalis. I replied that he had said that they were good workers. The respondent then said: "Ah, but I never sald that they weren't good workers."

In most of the other firms visited during the interview surveys, the writer gained the impression that, on the whole, 
coloured workers were reasonably well treated by management, although it was not always possible to verify this. Similarly, it was suspected in one or two cases that management was perhaps more demanding towards coloured workers - there were, for example, the comments in Bradfield Foundry that they stood for more "pushing around" and in Muirhead Foundry that it was unfair that Indians should receive equal pay because they were not as good as British workers - but again it proved impossible to obiain confirmatory evidence.

However, it may be significant that in such cases, the coloured workers concerned were usually Indians or Pakistanis. As we have noted, the white workers in Omega Metals claimed that the Pakistanis did not expect equal treatment. In the interviews with the Pakistanis themselves, none of them had any complaints about the treatment they had received, in spite of the overwhelming evidence of discrimination and the fact that they were specifically asked about the way management had behaved towards them. Of course, it is quite probable that they would not have been so reticent had they been interviewed outside the works by a fellow Pakistani who had no connection with the firm. On the other hand, it also seems to be the case that Indian and Pakistani workers tend to accept unfair or unequal treatment with much less protest or sense of discrimination than either West Indian or British workers. In Edge Tools, for example, one British worker claimed that whereas Pakistanis expected to be pushed around, West Indians seemed to want the same treatment as white workers. Similarly, the stress often placed on the amenability to 
discipline of Asian workers compared with the "touchiness" of the West Indians would seem to represent the same situation seen from the management viewpoint. Further evidence that Asian workers have, as it were, a lower level of aspiration with regard to working conditions is to be found in the next section when we come to examine job satisfaction.

\section{Job Satisfaction}

Data concerning job satisfaction amongst Asian workers were obtained in twenty-one formal interviews and in two informal interviews on the shop-floor. In the latter two cases, both respondents stated that they did not like their jobs. The first, a Pakistani crane driver in the Ridgeway Steel Co., simply said that he wanted a job with more money. The other, an Indian moulder's mate in Stainless Steel Ltd. stated:

It's not very nice work; the money is not very much. I don't stay here because of the money. I stay here because of Mr. - (the moulder whom he assisted) and Mr. - (another moulder). The people here are very nice so I stay. The Shop Manager, he is very nice too.

In the formal interviews, on the other hand, all twentyone respondents ${ }^{1}$ stated that they liked their jobs. In Edge Tools in particular, they seemed highly satisfied. Some comments

1. Five Pakistanis and one Indian in Bdge Tools, eleven Pakistanis in Omega Metals, a Pakistani in Major Castings Ltd., an Arab in Annerley Iron Poundry, a Pakistani in Polton Rolling Mills and an Arab in Steel Bars Ltd. 
were as follows:

I like everything: anywhere, anytime, I like. (Interviewer: "Would you prefer a better job?") This job better. All England better job!

(Pakistani Iabourer)

Here everything good, very good. Nothing I don't like.

(Pakistani labourer)

I like it very much; anytime job like. The Foreman is very nice - very good man.

(Pakistani testing machine operator)

All the respondents said that there was nothing about their jobs they disliked and only one sald that he would prefer to do a different type of work. A Pakistani general labourer in Polton Rolling Mills stated that although he liked his present job very much, he would have preferred "something mechanical." All the other Asian workers wanted to continue doing the same jobs.

of the twenty-five West Indian workers who were interviewed, 1 only seven stated that a) they liked their jobs and b) that there was nothing about them that they disliked. Even amongst these respondents, however, five said that they would have preferred another job if they could have found something better. A further two respondents stated that they liked their work in general, but

1. West Indian workers were interviewed in the following firms: six in Edge Tools, one in Omega Metals, one in Annerley Iron Foundry, two in Leigham Cannery, six in Hamilton Engineering Co., five in Torrington Cutlers Itd. and four in Pentland Alloys Itd. 
there were aspects of it which they did not - the wages in one case and the heat in another. Both would have preferred a better job than they had.

Nine of the West Indians described their jobs as "all right" or said that they neither liked nor disliked their work or words to that effect. Five respondents said that there were aspects of their work which they disliked and five that they would have preferred something better. ${ }^{1}$ Finally, seven respondents said that they disliked their work, two of them stating that they only continued with it because it was "better than the Labour Exchange."

In all, elghteen of the twenty-five respondents would have preferred a different job from the one they had. Elght gave no clear indication of the work they would have liked, and the preferred occupations of the remaining ten respondents were as follows: mechanical engineering, diesel engineering, "something mechanical" (two cases), electrician, builder, painter, crane driver, pipe fitter, and operator for the Midland Gas Board. Only three respondents had had previous experience in the fields they chose.

Fourteen respondents gave details concerning the aspects of their present jobs which they did not like. Four stated that the wages were too small and another that the opportunities for advancement were limited. Three respondents (all polishers in

1. There was, however, little overlap between these two groups. Only one of the nine respondents stated both that there was something about his job which he did not like and that he would have prefered something better. 
Edge Tools) found the work too arduous, three stated that they did not like the dust, one that the job was too dirty, another that it was too hot, and two that they did not like working in acid because of the fumes.

Thus, in general, job satisfaction was much higher amongst the Asian workers than the West Indians. Only in Edge Tools was it possible to interview members of each group in appreciable numbers, and this case is particularly revealing. All six Asian respondents stated that they liked their jobs compared with only one of the West Indians. Two of the West Indians stated that their jobs were all right and the remaining three that they did not like them. This difference was even more striking in view of the Labour Manager's claim that the West Indians had the better jobs. The firm employed only a few West Indians, he stated, because they would only work in the Polishing Shop where the money was good, whereas the Asian workers would accept any job.

\section{Labour Turnover}

Writing in 1955 Banton suggested that there was a relationship between the level of job satisfaction and rates of labour turnover amongst West African and West Indian workers. He stated:

The ambitious immigrants find (the restrictions on vertical mobility) frustrating, and for a time, they cannot believe that all jobs are as unrewarding as those they have tried. This leads them to change from one to another "in the hope of getting the right job someday." 
In all but one of ten firms visited by Banton as representative of the main employers of unskilled labour in Stepney, labour turnover was sald to be much higher amongst West African and West Indian workers.

Since Banton's study, however, the situation has changed radically, mainly, it would appear as a result of fluctuations in the state of trade. According to Patterson (1960), one consequence of the 1956-58 recession was that West Indians in work ceased to regard their jobs as expendable; their timekeeping improved, and many employers who had formerly criticised their nonchalant attitude and high mobility gradually came to regard them as more rellable than most in these respects. Wood (1960) reached much the same conclusion on the basis of a research study carried out in 1959. He states:

When coloured workers get permanent jobs they tend to stick to them. No longer are the complaints of a few years ago heard that coloured workers, particularly West Indians and West Africans, leave jobs suddenly when they hear of a factory down the road which offers them a few shillings a week more. The recession had a chastening effect on this kind of restlessness. Employment Exchange managers and personnel officers agree that the turnover is now the same as or often lower than that of white workers in comparable jobs. Only in Cardiff, where there is no great recently arrived coloured population, was it belleved that the labour turnover was higher.

A similar pattern emerged from the present research. A few managers still believed that labour turnover rates were higher amongst coloured workers, but the majority claimed that 
they were as low or even lower, and more often the latter.

In the questionnaire survey, twenty-two respondents (48\%) stated that labour turnover was lower amongst coloured workers than amongst white, fifteen (33\%) that it was about the same and only nine (19\%) that it was higher. In one further firm labour turnover was said to be higher in the case of Pakistanis, but no reference was made to the West Indians also employed by the firm. In no other case was a distinction made between the labour turnover rates of West Indian and Asian workers.

In the interview surveys, data concerning labour turnover was obtained in twenty-six firms in all. It was said to be higher than amongst British workers in four firms, ${ }^{1}$ about the same in five firms, ${ }^{2}$ and lower in fifteen firms. ${ }^{3}$ In the remaining two cases ${ }^{4}$ the data did not readily fit into the above categories and must be examined separately.

In Tool Steel Itd. the Personnel Manager described labour turnover amongst coloured workers as "not bad", but suggested that it followed a different pattern than amongst white workers. He stated:

Coloured workers stay two, three or four years and then go back home. If a white man is here this length of time, he is usually here for good. So I think you could sum up labour turnover amongst the coloured workers by saying

1. Firms 5, 24, 26, 30 .

2. Firms 16, 20, 21, 22, 31 .

3. Firms 2, 3, 7, 9, 10, 11, 12, 13, 15, 18, 23, 25, 27, 28, 29. 4. Firms 17, 19. 
that they have longer short term engagements.

In Leigham Cannery, on the other hand, the Personnel

Officer suggested that the labour turnover pattern differed

between coloured men and women. In the case of the women, labour turnover was about the same as amongst white women, but in the case of the men, it was very low indeed.

Among the men, it would be nil if they had their way. Labour turnover is mainly due to redundancy. 1 Once a coloured man gets over his training period, he tends to stay as long as we will keep him.

Claims that labour turnover was so low amongst coloured workers as to be almost non-existent were found elsewhere in the present research. The Personnel Manager of Muirhead Foundry stated, for example:

You have to have more Indians in to find a good one, but once you have found him, you don't have turnover. The English workers are continually turning over.

Similarly, the Personnel Manager of Drop Forgings stated:

There is no labour turnover with Jamaicans; they rarely leave.

Oddly enough, another example of negligible labour turnover amongst West Indians was found in one of the firms where labour turnover was said to be higher than amongst white workers. The Personnel Manager of Ensign Springs Lta. claimed that although 
the firm had no colour bar, they would hesitate to employ any more coloured workers than they already had. It would be a bad policy for any industry to employ too many coloured workers, he stated, because they tended to move from district to district. The respondent asked me whether I had found the same thing in the course of my studies. I replied that I had heard conflicting reports, some managers stating that they moved around between districts ${ }^{1}$ and others that they tended to remain in the same job because they would not easily obtain another one. The respondent then agreed that, because they were grateful to have a job, West Indians inlght stick to an unskilled job where a white worker would leave. Iator, when asked specifically about labour turnover amongst coloured workers, he stated that it was nil. He claimed, however, that this was because they were only employed where necessary; if more were employed, he stated, labour turnover would be "tremendous".

In the remaining three firms where labour turnover was sald to be higher, Asian workers (mainly Pakistanis and Arabs) were employed. The Personnel Marager of Sterling Metal Co. stated that coloured workers were "more mobile" than British workers, although not so much now as they used to be. In Stalnless Steel Itd. the Works Manager claimed that coloured

1. Only one manager had, in fact, mentioned this question at this stage. The Works Superintendent at Bradfleld Foundry stated that Pakistanis (who were not employed in Ensign Springs Ltd.) had at one time tended to move backwards and forwards between the Midlands and Yorkshire, but this no longer happened to any great extent. 
workers tended to leave for trivial reasons without giving the job a fair trial. Two coloured workers had left because they were put on outside jobs and another two because it was too wet. The white worker, the respondent thought, would try the job for about three months before he left.

Finally, in Blackford Rolling Mills, the Production Services Hanager claimed that both labour turnover and attendance were worse amongst coloured workers. He stated:

We find that they do not have the attitude of being here five days a week. They will take the odd day off. We also found this with the permanent coloured workers; generally they were unreliable from the attendance point of view. Labour turnover is rather higher than with non-coloured workers, there's no doubt about that. They don't require much provocation to leave one job and get another. It ties in with their attendance. They are far worse than our own workers in both respects.

Little support for this contention can be found elsewhere in the present research. We have already seen that most managers had found labour turnover amongst coloured workers no higher than amongst white. Similarly, although no systematic data were collected concerning attendance, the respondents who mentioned this subject invariably stated that it was better amongst coloured workers. It must be remembered, however, that the above firm had ceased to employ permanent coloured workers some four years previously and patterns of labour turnover and attendance could have changed considerably in the intervening period. 
Thus far we have mainly been concerned with labour turnover arising from coloured workers moving from one job to another. In the case of Asian workers, however, several respondents also mentioned the question of coloured immigrants returning to their own countries. In one of the firms in the questionnaire survey, labour turnover was said to be higher amongst Pakistanis "due to the attractions of returning to their homeland when they have accumulated sufilcient money." In another firm, employing Indians and Pakistanis, the respondent stated:

There is only one criticism we have to make and that is that we find that after they have worked here for a certain length of time and have learnt all we have to teach them, they have a tendency to return to their native land which, of course, places us in an awkward position although we can understand their feelings in this matter.

Further examples were found in the interview surveys. As we have already noted, the Personnel Manager of Tool Steel Ltd. claimed that coloured workers tended to return home after two, three or four years. In Steel Bars Ltd, the Works Director stated :

Labour turnover is negligible. In general, once they are here, they stay. Except for going home that is. With their standard of living, they could save about 21,000 in two to three years and then go back home again and set themselves up in business. Or they might save $\$ 400$ to $\$ 500$ and "plonk" it on my desk and ask me to have it sent home to their father to buy a shop, for example. 
This has happened. One bought property and set up a "doss house". He got $\$ 40$ to $\$ 50$ a week in rent, so he gave his notice. He made about $\$ 2,000$ to $\$ 3,000$ and went home a rich man. At least, a comparatively rich man by his standards.

In other firms, the question of Asian workers returning home for an extended holiday was mentioned. In Edge Tools, labour turnover amongst Pakistanis was generally low, but the firm had recently lost soine workers who had gone back to Pakistan. They had wanted a guarantee that they could have their jobs back when they returned, but the firm had refused to do this. One reason was that it was impossible to predict what the state of trade would be like when they returned, and another that they would have to be replaced and the firm could not simply sack the replacements when the returnees wanted their old jobs back again.

Similarly, during an interview with the Assistant Personnel Manager of Ridgeway Steel Co., a Pakistani asked the respondent whether the firm would hold his job for him whilst he went back to Pakistan. The respondent said that he supposed that the man would want a month off, but the Pakistanl replied that he wanted a year - he couldn't spend all that money going back to Pakistan for just a month. The Assistant Personnel Manager stated that, in that case, he would just have to take "pot luck" when he came back and suggested that the man should write to the firm about two months before he was due to return and they would "see what they could do." 
In one of the interview survey firms, on the other hand, Pakistanis were granted up to a maximum of six months home leave after the completion of three years' service and subsequently at intervals of five years. The respondent stated that labour turnover amongst Pakistanis was low for this reason.

Finally, the question of Asian workers returning home was also mentioned in Grange Graphite Co., but in this case the respondent was dubious as to whether they always gave the correct reason for leaving. The Personnel Manager stated:

Three coloured workers have been here twelve years. The average length of stay is about three years with a median figure of three years as well. They leave for three main reasons: they leave for Bradford, they leave for Birmingham and they leave for Aden. They can pack up and leave easily, probably due to the lack of personal possessions. You never really know why they are leaving. They say they are going to Aden and three weeks later they are back for a job. Their concept of truth seems to be entirely different from ours. They say they are going to Aden and they know they are not going to Aden and you know they are not going to Aden and they know you know, but they are still going to Aden. I have very rarely had one come in and tell me he is leaving because he has got a better job.

Nevertheless, it should be noted that in the above firm and in Ridgeway Steel Co. it was stated that there was no difference between the labour turnover rates of white and 
coloured workers. Similarly, in both Edge Tools and Steel Bars Itd., labour turnover was said to be low in spite of the fact that some Asian workers had left to return home. This, combined with the low rates of turnover found generally, suggests that the number of Asian workers returning to their own countries is insufficient, as yet anyway, seriously to affect labour turnover.

Thus, although there were a few exceptions, the present data indicate that levels of labour turnover amongst both Asian and West Indian workers are remarkably low, How then are we to account for this situation? Can it be suggested for example, that the 1956-58 recession brought about a long term change in the attitudes of coloured workers towards stability of employment? Whilst this may be the case, it must also be remembered that the field work of the present research was mainly carried out in 1962 and 1963 at the beginning of and during another major recession, when coloured workers were once more finding employment scarce.

Several managers, in fact, attributed the low levels of labour turnover amongst coloured workers to the difficulties of obtaining alternative employment. In Central Glass Works, for example, the Personnel Manager claimed that they were "afraid that if they left one job, they might have to walk the streets for months before they found another." Similarly, the Personnel Officer of Trafford Iron and Steel Co. stated:

We have had no difficulty with labour turnover. Under present conditions the reverse 
1s the case. The West Indian is anxious not

to lose his job, presumabty because he would not find another one easily.

Some supporting evidence was found in the interviews with coloured workers, particularly the West Indians. As we have already shown, job satisfaction was relatively low amongst West Indian workers. Nevertheless, several respondents who either did not like their jobs or would have preferred a better one stated that they would remain in their present employment. Examples include:

Well 1t's hard work and nobody likes hard work, but there's no other, so I've got to stick to it.

$$
\text { (Polisher, Bdge Tools) }
$$

The money's a bit short, but I am quite satisfied until I can find something better. It's a bit tough to get work now and it is better to stick.

(Labourer, Torrington Cutlers Ltd.)

I don't like it very much, but I stick to it because it's better than going to the Labour Exchange.

(Window Cleaner, Torrington Cutlers Itd.)

I would really like a different job where

I could learn something, but it's very

difficult to find a better job now. Jobs are scarce.

(Turner's mate, Pentland Alloys Ltd.)

On the other hand, there were also indications that, irrespective of the state of trade, some of the respondents 
preferred stability of employment. A West Indian sand miller In Hamilton Engineering Co. stated:

The job carries a lot of dust, but I would rather remain on $1 t$. I just love a steady job.

In two other cases, "skilled" ${ }^{1}$ West Indians had become resigned to the fact that they could not obtain jobs in their own fields. In Edge Tools, a cabinet-maker now employed as a polisher said:

At first I would have liked my old job, but not now. It's been so long that it doesn't make any difference.

And in Torrington Cutlers, a West Indian who had previously been a painter, said of his present job (stripping silver):

I've got so accustomed to it now that it doesn't bother me. If I could get a job as a painter, I would accspt it, but if I can only get another job like the one I have here, I will continue.

The respondent had, in fact, tried to obtain a job as a painter, but had been told, he claimed, "Sorry no Coloureds." However, this had occurred some five years previously, and it would appear that since then he had not tried to obtain work in his own field. Similarly, another West Indian employed in

1. That is, skilled according to their own standards, of one of these respondents a white worker in the same firm (Torrington Cutlers) stated: "The one in our department was a brush hand, painting corridors in a hospital; he told a firm he was a skilled painter, and he was most upset that they wouldn't take him on." 
the same firm stated:

I would like to get back to my old trade doing building work, but I would lose a day if I went out to try for another job and it's difficult at week-ends.

There 1s little evidence in the above comments of Banton's highly mobile West Indian moving from firm to firm in the hope of finding the right job some day, or of the tendency to leave jobs for trivial reasons reported by Wood. This change may have been brought about partly by the "chastening effect" of the 1956-58 recession and partly by present trade conditions. However, there were also signs that some West Indians at least had lowered their level of aspiration and, following the disillusionment of the high hopes with which they arrived in this country, were now prepared simply to "make the best of things." 


\section{CHAPTER EIGHT}

\section{INTERGROUP RELATIONS AT WORK}

\section{Preliminary Summary}

We turn finally to an examination of intergroup relations at what may be termed the shopfloor and works canteen level. This is perhaps the most complex aspect of the present research, involving not only the attitudes of the white workers towards the coloured immigrants, but also the attitudes of the different coloured groups both towards the white workers and towards each other. We shall first be concerned with the attitudes of the British worker towards the coloured immigrant as a fellow worker. It is concluded that British workers are in general prepared to accept coloured immigrants in work relationships, although many would prefer, other things being equal, to work where only white people were employed. At this stage, the question of whether coloured immigrants are prepared to accept white workers does not arise. As newcomers to British industry, this is an unavoidable necessity for the immigrants if they are to obtain employment at all. However, this does not apply in the realm of social relationships. Social acceptance of members of a different national group is no more a condition of employment for coloured workers than it is for white. Whilst there was considerable variation both within and between the firms 
studied during the present research, the level of social integration was found to be relatively low. This can be explained only partly in terms of a lower level of acceptance of coloured immigrants in social as opposed to work relationships on the part of the white workers. There was also a tendency for the coloured workers to prefer to remain within their own social groups, and this applied equally to their relations with other coloured nationalities as to their relations with white workers. Similarly, although overt social conflict was rare, this occurred no more between white and coloured workers than between the different coloured nationalities. It is suggested that the relatively high level of social distance between the various national groups, white and coloured, can largely be attributed to differences in cultural background, either major differences of customs, values and language or minor differences of interest and topics of conversation. However, beliefs concerning social status in the case of the white workers and fear of rejection on the part of the West Indians also appear to be relevant. 
1. Introduction

One of the first firms to be visited during the present research was Bradfield Foundry. In all, five or six weeks were spent there interviewing management representatives and observing white and coloured employees at work. The labour force consisted of 134 male and 22 female workers. Of the male workers 37 were British, 12 Italian, 4 West Indian, 4 Arab and 77 Indians and Pakistanis. Of the latter, about 50 were Indians, mainly Sikhs. The female labour force consisted of 19 British women and 3 West Indian. It seemed, therefore, an ideal firm in which to begin observing "race relations in action", as it were.

By the end of the period of observation, however, I had come to the conclusion that race relations as such just did not exist in this firm. At this time, I had been studying race relations for only a few months and my ideas were still influenced by preconceptions which had grown up on the basis of second hand information (newspaper reports and so on). Looking back on it now, I realise that, somewhat naively, I was trying to discover whether relations between the races were "good" or "bad". Good race relations, I thought, would show themselves in acceptance of the coloured workers by the white and friendly relations between the races. Bad race relations, on the other hand, would demonstrate themselves in rejection of the coloured workers, prejudice and discrimination against them and friction between the races. Neither, however, was the case in this firm. In general, interaction between the different national 
groups was minimal. Whilst actually working, the behaviour of the workers was almost entirely task-orientated. There was little or no social intercourse; such interaction as did occur was mainly concerned with work and there was little enough even of this because the work did not demand it. Admittediy, social interaction did take place during lunch and tea-breaks, but very little of this was interracial. The workers tended , to split up into groups consisting of one nationality only and there was no interaction between the groups.

Thus, being unable to carry out my original intention of studying "race relations", I decided to do the next best thing and study the apparent lack of them. The morning teabreak seemed to present the best opportunity of doing this as it was possible to observe the change-over from work to social relationships. Accordingly, I went round the factory at this time on several mornings and made a note of where people worked, where they spent their tea-break and what happened before and during the tea-break. The following is a description of what occurred on a typical morning at this time.

All morning there has been the continual noise, vibration, dust and dirt of industrial machinery operating at full pressure. The work is carried out in a brick-walled, corrugated roofed building about one hundred and twenty feet long and sixty feet wide. The floor appears to be packed earth, but there may be concrete somewhere underneath it. It is difficult to tell. The production line begins in the moulding department. There are twenty moulders, eight Indians, seven Italians, four British workers and a Pakistani. 
The finished moulds, consisting of machine compressed sand in a wooden or metal frame, are placed on the "track" (a circular conveyor system) and thus carried a short distance to the casting platform. Here, six casters, a Pakistani, a West Indian and four Indians, fill the moulds with molten metal carried manually in ladles from the Cupola. The filled moulds are then carried by the slow moving track, cooling and setting as they go, to the knock-out. Two Pakistanis and an Indian then drag them off the track on to a vibrating grid. The mould breaks up: the sand falls through the grid, the red-hot castings are placed on another conveyor system and the frames are placed back on the track to be transported back to the moulders.

After the castings have cooled, they are inspected for flaws by two women, one British and the other West Indian. Some then go to the Grinding and Drilling Department where there are six grinders (three Pakistanis, one British worker, an Indian and a West Indian), two drillers (an Arab and an Indian), an assembler (a Pakistan1) and two bench workers (both British). Others go to the Fettling Department which is staffed by a British foreman, five Indians, two Italians, a Pakistani, an Arab and a British worker, all on bench work, drilling or grinding. Subsequently, the castings are reinspected, painted and sent to the Dispatch Department.

Work is carried out at high pressure as the product in various stages of completion proceeds through the different departments. There is little need for communication about work as the mould or casting is carried from the previous operator and on to the next mainly by means of conveyor systems. As long as the moulds or castings are available, therefore, each operator is able to carry out his operation in virtual 
independence of the rest. Social communication is minimal and in many cases non-existent. In general, the workers appear to devote their entire attention to the task in hand, having neither the time nor the inclination to interrupt this with social activities. ${ }^{1}$

At about 9.45 a.m., however, the pace slackens somewhat and preparations begin to be made for the morning tea-break. An Indian places a saucepan (later seen to contain curry) on a red-hot casting on the moving conveyor-belt, and then carries on working. Another Indian is heating a saucepan on a similar casting on the shop-floor. A West Indian woman is toasting bread in front of a stove in another part of the factory. Chapatis are being heated over a brazler in yet another part of the factory. An Indlan working next to the track leaves his place of work, goes further up the conveyor system, places a billy can of water on one of the freshly filled moulds and goes back to work again. The mould, contalning red-hot metal, continues to move along the track. Five minutes later, it has almost reached the Indian's work position.

At ten o'clock an electric bell is rung. The conveyor-belts are brought to a halt, the moulding, grinding, and drilling machines are switched off, the casters lay down their ladles and the workers begin to congregate in groups.

The Indian casters and Indians from other parts of the foundry gather round the brazier next to the casting platform. On the brazier billy cans of water are bolled, chapatis are heated and saucepans full of curry are cooked. One of the Indians leaves the group to heat a chapati in a casting ladle which has recently

1. N.B., the majority of employees are on piece work or bonus. 
held red-hot metal, then rejoins the group. Tea and sugar, measured out by the handful, are added to the freshly boiled water and the Indians squat or stand around drinking tea and eating pieces of the chapatis dipped into the curry. The group round the brazier is quite lively and boisterous, with much talking and shouting back and forth.

One Indian who does not join this group is the man who was working next to the track. By the time the tea-break bell was rung, his can of boiling water was within a foot or so of his place of work. Having made his tea, he then heats a saucepan of curry on the now stationary mould. Usually he eats alone, but occasionally he is joined by one or two other Indians. He is somewhat older than the Indians who congregate round the brazier and spends his lunch time in a much more quiet and leisurely manner.

The Pakistanis squat together in a group on the opposite side of the casting platform from the Indians. The Italians sit in a group at the end of the line of moulding machines drinking tea and eating sandwiches. Although the two groups are quite close together, there is no social interaction between them.

The rest of the moulders sit in small racially homogeneous groups in amongst the moulding machines. Two Indlans (one of whom has the record for mould production) are working on their machine apparently trying to rectify some fault.

The West Indian caster and one of the Cupola attendants (a British worker) spend the tea-break together, sitting on a small bench next to the Cupola, 
drinking tea and eating sandwiches. 1

The workers in the Fettling Department spend their tea-break sitting round the only stove in the department. The group consists of two British women, one male British worker, several Indians and an Arab. Whilst the different nationalities are not broken up into separate groups, there is a tendency for people sitting next to each other to be of the same nationality. There is much less social interaction than in the racially homogeneous groups, and what interaction there 1s, takes place mainly between people of the same nationality. The Indians in this department are eating English food.

On the opposite side of the track from the casting platform, four or five British workers sit drinking tea and eating sandwiches. Two members of this group work in this position, the others coming from different parts of the foundry.

The coloured workers in the Grinding and Drilling Department are gathered together in a large racially mixed group next to the grinding machines. There are several Indians and Pakistan1s, the West Indian grinder and one or two Arabs. The two British bench workers in the department sit together at some distance from the coloured workers. At some distance from both these groups sit two British women (both inspectors). Later, they are jolned by a West Indian woman, also an inspector,

1. The Technical Controller stated that although the West Indian caster usually spends his tea-break with the Cupola attendant, he goes and sits with another West Indian in the Dispatch Department during the lunch break. According to the respondent, he could not do this during the morning tea-break because there was insufficient time. The Technical Controller also stated that the West Indlan caster was "not too happy" about the fact that h1s work-mates were all Asians. There used to be two other West Indlans on this job, but they have both left and he is now the only English-speaking caster. 
who remains with them for the rest of the tea-break.

At 10.15 a.m., the electric bell is rung once more, signifying the end of the tea-break. The West Indian caster starts up the track, the moulding, grinding and drilling machines are switched on and the second half of the morning's work is begun.

Further information concerning race relations in this firm was obtained from interviews with management representatives. The Works Superintendent stated:

When we first began employing coloured workers, I envisaged race riots and all kinds of trouble, but by and large they have settled down and been accepted without difficulty. You still get some British workers who will say, for example, "What else can you expect from a bloody nigger", but it never comes to anything.

On the other hand, the respondent claimed that there had been some friction between Indians and Pakistanis. For example, an Indian would point out to a supervisor that a Pakistani had done a hopeless job on some task, not so much as a means of "telling tales" on a particular person, but rather to demonstrate that all Pakistanis were hopeless. Similarly, the Fettling Shop Foreman claimed that Indians and Pakistanis did not get on well together; if placed on the same job, each would blame the other if anything went wrong. Such friction as there was in the foundry, the Works Superintendent concluded, occurred between Indians and Pakistanis; it did not occur between West Indian and Asian workers who tended to ignore each other, nor between white workers and coloured workers in general, nor 
between the two groups of white workers, the Italians and the British.

Two main points arise from the foregoing account. Firstly, it is an over-simplification to view race relations in such a context in terms of white/coloured dichotomy. There is a complex pattern of relationships, and whilst such concepts as a colour bar and racial prejudice on the part of white workers may have some relevance, they cannot provide a full explanation of the situation.

Secondly, even if we isolate the attitude of white workers towards the coloured, this cannot be described in terms of simple acceptance or rejection. The white employees were prepared to accept the coloured immigrants as workers, in the sense that they did not threaten strike action if they were employed, nor did they refuse to work with them. It may be that they would have preferred white work-mates and only accepted coloured workers because white workers could not be obtained, but they accepted them nevertheless. On the other hand, they did not in general accept them in the social context. We would suggest, therefore, that the study of intergroup relations in the works environment should be approached from three main standpoints:

1. Attitudes of the British workers towards coloured immigrants as work-mates.

2. Social relations between white workers and coloured workers, and

3. Where more than one nationality of coloured immigrants 
is employed, work and social relations between the different coloured groups

In the next three sections, we will examine each of these topics in turn.

2. British Attitudes Towards the Immigrant as a Worker

a) Level of Work Acceptance

As we noted in Chapter Four, opposition from British employees has in some firms prevented or deterred management from employing coloured 1mmigrants. Unfortunately, we cannot estimate from the present data how commonly this occurs as the majority of firms studied did in fact employ coloured labour. In these firms, however, remarkably little opposition to the coloured worker was reported by management.

In the questionnaire survey, it was stated in thirtysix firms out of fifty that no initial resistance to the employment of coloured workers had been experienced. In seven firms there had been some opposition on the part of the white employees and in a further seven firms slight resistance had occurred. In some cases, the earlier resistance was overcome and coloured workers eventually gained acceptance. At the time the survey was carried out, coloured workers were said to be accepted as work-mates in forty-five of the firms. In three, coloured workers were still not accepted and in two cases uncodable answers were received.

A similar pattern emerged from the interview survey. In twenty firms no initial resistance to the employment of coloured 
workers was reported. Often, the agreement of the white workers was obtained before coloured labour was introduced. In Edge Tools Ltd., for example, the Labour Manager stated:

When it became necessary to employ coloured workers, the position was explained to the whites at a meeting. It was guaranteed that no white man would ever be excluded by the employment of coloured people. The men were left to think it over for a day or so. There was no resistance, nor has there been any trouble right from the start.

And according to the Works Manager of Annerley Iron Foundry:

Management had the unions' blessing when coloured workers were employed. All the coloured workers are in the union. ${ }^{1}$

In the remaining eleven firms, some initial resistance to the employment of coloured labour had occurred. In some cases, ${ }^{2}$ only a certain section of the white workers, usually those in skilled trades, had been opposed to their employment, whilst the remainder had accepted them. In Central Glass Works, for example, coloured workers had been accepted in the production departments, but the skilled shops and the maintenance department had refused to take them. Similarly, in Pentzand Alloys Itd. some of the white workers in the hot rolling

1. Consultation with the white workers with respect to the employment of coloured labour was also reported in Firms $1,3,7$, $11,15,18$ and 31 .

2. Firms 11, 15, 17, 23 and 31 . 
department had been reluctant to accept coloured workers so management had employed them elsewhere. In Major Castings Ltd. and Sovereign Steel Works, several departments had refused to accept coloured labour at first, but some had later relented. In Sovereign Steel Works the Personnel Manager stated:

Certain departments refused them for a time, and some still do, certain skilled trades such as building. We had great difficulty getting them accepted in the machine shops, but by and large, they have now been accepted everywhere except in the building and electrical shops.

In the other firms, ${ }^{1}$ there had been a general reluctance to accept coloured labour. Often, however, this was slight and relatively short lived. In Steel Bars Ltd., for example, the Works Director stated:

I suppose if you went right back to the start, we didn't have any difficulty, but we did have some back-chat and grumbling. A sort of mild reproach to management. But they realised that we had to have men and that it was better to have a coloured man than no jobs. After about a year, they discovered that they (the coloured workers) were friendly. And generous - some of the white men kept borrowing money off the Arabs until we put a stop to 1 t.

Similarly, in Stainless Steel Ltd:

There was some initial difficulty with the white workers. This is a non-union firm ..... so there was an undercurrent rather than an official out-

1. Firms 20, 24, 25, 26, 28 and 29. 
cry. They said they weren't going to eat in the same place as the coloured workers, and if they were going to use the showers, well that was the end! When they saw the menial jobs being done and helping them to get their bonus, they soon shut up.

(General Manager)

And in Sterling Metal Co.:

The greatest objection was from the economic standpoint - overtime and redundancy. This was easy to overcome - we pointed out that the coloured workers were getting the jobs they dian't want. Now the whites have come round and insist on equality in redundancy last in, first out, irrespective of colour. (Personnel Manager)

By the time the interview survey was carried out, coloured immigrants had been accepted as workers in the majority of firms visited. Only in Muirhead Foundry was it reported that the white employees in general were still strongly opposed to the employment of coloured labour. In this firm, coloured workers had been employed since it was founded two years previously, and although the white employees were prepared to work w1th them because, other than leaving the firm, there was no alternative, their presence was still resented. Even here, however, the coloured workers were not completely rejected. According to the Personnel Manager:

The British workers realise that it is impossible to get sufficient white workers, so they just accept them on sufferance. In gerieral the British 
workers do not like them - although they do

like them in certain jobs because they do hard graft.

In the main, however, the attitude of the white workers seemed to be neither favourable nor unfavourable, but rather one of indifference. The coloured workers were accepted, but this did not denote a positive orientation towards them, merely the absence of rejection. Some typical reports by management were as follows:

By and large they accept them, but they don't either like them or dislike them. There is no non-acceptance except by a minority, nor are they favoured except by a minority.

(Personnel Officer, Sovereign Steel Works)

They're indifferent: they don't like them, but they're indifferent - they don't actively dislike them. It's like the U.S.A. and Red China: they don't like them, but they try to pretend they aren't there.

(Personnel Officer, Grange Graphite Co.)

I don't know ..... I suppose they accept them, but they tend to be indifferent. If you put it to the vote, they'd rather be without them.

(General Manager, Stainless Steel Lta..)

Comparative data from the white workers on this question is somewhat limited; owing to the reluctance of managers to al. 0 formal interviews only twenty-five complete questionnaire schedules could be obtained. What information there is, however, 
does tend to support the above conclusions. White workers were first asked how they felt about working for a firm which employed coloured labour. The majority of respondents claimed that they did not mind or were not greatly concerned over this matter. Some typical responses were as follows:

On, they're all right, they don't interfere with my job.

(Edge Tools Itd.)

I've got nothing against coloured workers. (Omega Metals Itd.)

I'm not bothered; they don't interfere with me.

(Omega Metals Ltd.)

It's Immaterial to me what colours they are as long as they work all right.

(Leigham Cannery)

If they'll work, if they'll pull their weight as a member of a team, I don't mind what colour they are.

(Torrington Cutlers Lta.)

At this stage only three respondents indicated that they were not prepared to accept coloured workers. However, when subsequently asked whether, other things being equal, they would prefer to work where only white people were employed, fifteen respondents stated that they would. Even amongst those who said that they would not, the attitude seemed largely to be one of indifference. For example, a worker in Omega Metals Itd. stated: 
I get on with them all right; there's good and bad in every race. You just have to accept them. I don't mind working with coloured chaps; they don't interfere with me and I don't interfere with them.

And in Hamilton Ingineering Co, another said:

It's difficult to answer because there's only three or four, but if there was a lot ....... I'm not frightened they might take my job you see. Some of the other blokes, if they are labourers, might be worried about losing their jobs because of them, but they don't bother me.

In six cases, ${ }^{1}$ however, the white respondents had a positively favourable attitude towards coloured workers. In Torrington Cutlers a white worker stated:

Both socially and to work with, I've found them very good. They've been hard workers, and they've done everything they've been asked to do. And I don't think we've ever had any troubl:s.

And in Pentland Alloys Ltd. two skilled white workers indicated that they preferred West Indian labourers:

I find them just as good as, well in fact better than our own. There's one thing about them, they will work.

No I wouldn't (rather work where only white people were employed). I've had some terrible white labourers - laziest buggers under the sun.

1. One respondent in Torrington Cutlers, one in Steel Bars Ltd. and four in Pentland Alloys Ltd. 
Further examples of favourable attitudes towards coloured workers were also found in the informal, shop-floor interviews with white workers. In Stainless Steel Ltd. a moulder said of his Indian labourer:

He's champion. I couldn't hope to get a better mate. I'd rather have him than any of the white men we've got here. He's a very willing worker. You just tell him what to do and he gets on with 1t. You can leave him on his own and he carries on working. If I had a white mate and I left him, he would be waiting for me to tell him what to do when I got back. But not this bloke. He could just about do my job for me. And he's only been here about a year and he'd never worked in a foundry before that. Now he knows more about moulding than any other labourer in the firm. Well he knows more than some of the moulders for that matter. Some of them have to ask me which cores go into a particular mould, but he knows them all.

In Sovereign Steel Works two rollers spoke very highly of the coloured workers in their teams. The first praised coloured workers in general for their wlllingness to work and stated that in this respect they were much better than white men. If there was a job to be done, he said, they would get on with 1t whereas the white workers would stand around and wait. The number two man in this team was an Arab. The roller stated that it was only the language difficulty which was holding him back from further advancement; if he could read and write English, he could become a roller with no difficulty. The second roller stated that the coloured workers were all keen 
workers and ready to learn the job above their own in order to gain promotion. They were, he sald, prepared to stick to the job, whereas the white workers had tended to drift out of the rolling mills.

We had a white bloke, a roller, who came in from another firm. He came in, rolled his first billet, and walked off the job, and we never saw him again. So that doesn't say much for your white bloke does 1 t?

In both teams, the coloured workers were mainly Arabs.

To summarise: the data thus far indicate that coloured immigrants were largely accepted as workers by the white employees in the firms under consideration. This acceptance, however, was largely of a negative nature. Few white workers were vehemently opposed to the coloured workers, but at the same time, few had a positively favourable attitude towards them. The majority, other things being equal, would have preferred not to work with coloured workers.

b) Variables Affecting the Level of Work Acceptance

In the previous section, we discussed work acceptance only in general terms. However, a number of factors appeared to affect the general level of acceptance. These included the number of coloured workers employed, the skill level of the jobs they obtained, their nationality, and the state of trade. Most of these topics have already been considered in relation to the employment and occupational level of coloured workers.

We noted in Chapter Four that some managers believed that 
whilst coloured workers were accepted in a minority, resentment might arise if they were employed in larger numbers. Little additional data on this question were obtained in the interviews with white woricers, but if we accept that the majority of respondents would have preferred to wor where only white people were employed, then it would seem reasonable to assume that they would be more prepared to accept coloured workers, the fewer were employed.

Some information was obtained in the interviews with white workers concerning the variation in work acceptance according to the status level of the jobs which coloured workers obtained. However, the questions asked in the pilot survey (Edge Tools and Omega Nietals Ltd.) differed in form from those asked in subsequent interviews. In the former, workers were asked whether they would accept a coloured worker in their own job and in a job above theirs, whereas in the latter the status level of the job - labouring, semi-skilled, skilled, supervisory was stipulated. The responses to these questions are presented in Table 20.

Table 20: Work Acceptance in Relation to Job Status

\begin{tabular}{|l|c|c|c|c|c|c|}
\hline \hline $\begin{array}{l}\text { Pilot } \\
\text { Survey }\end{array}$ & \multicolumn{2}{|c|}{ Accept in own job } & \multicolumn{2}{|c|}{ Accept in higher job } & Total \\
& 9 & \multicolumn{2}{|c|}{4} & 11 \\
\hline $\begin{array}{l}\text { Subsequent } \\
\text { Interviews }\end{array}$ & Accept as Labourer & Seri-skilled & Sikilled & Supervisor & Total \\
& 11 & 9 & 7 & 1 & $12^{1}$ \\
\hline
\end{tabular}

1. Due to pressure of time this question had to be omitted in two interviews. 
It will be seen that the level of work acceptance tended to decrease the higher the status of job the coloured worker obtained and in particular, there was a general reluctance to accept a coloured worker in a supervisory position. Furthermore, it should be noted that whilst these responses may represent the individual views of the white workers concerned, the general level of acceptance in the higher positions may be lower in a group situation. In Pentland Alloys Ltd. a Foreman stated:

You can't take what they say at face value. They talk like that (on job acceptance) when they are on their own and believe it, but it is a very different story when they get together, say at a Union meeting. A few people, about $10 \%$, will take a much harder viewpoint and the rest will fall into line with the others for fear of being out of step.

Similarly, a Union representative in Sterling Metal Co. stated that, although the majority of white workers did not mind coloured workers obtaining the higher jobs, there was always one trouble-maker who would make a fuss and eventually get the others on his side.

Nevertheless, there were cases in this firm, and in Steel Bars Ltd. where coloured workers had been promoted to the intermediate jobs in the rolling sets with white workers beneath them and had been accepted. Similarly, in Precision Engineers Ltd, and Drop Forgings Ltd. there were skilled coloured workers with white assistants. Thus, as the interviews 
with white workers would suggest, coloured workers are not invariably rejected in superior positions.

With regard to the nationality of the coloured workers employed, there was a general tendency for West Indians to be preferred as work-mates. (See Table 21) The usual reason given was their ability to speak English and the fact that their way of life was more similar to that of British people.

\section{Table 21 : National Preference of White Workers}

West Indians

Pakistanis

Arabs

No preference

Total
13

3

1

8

25

Only in one firm however, did the British workers refuse to work with Asian immigrants. 1 In Central Glass Works, the white workers were consulted before coloured labour was employed. According to the Personnel officer, the British workers had been prejudiced against Asian immigrants because of their sanitary habits and because of the fear of disease being spread. As a result, only West Indian workers were employed.

Finally, we turn to the effect of the state of trade on work acceptance. The majority of white workers (nineteen out of twenty-five) stated that, other things being equal, white workers 
should be given preference for jobs in the event of a recession. However, only three respondents claimed that white workers should still be given preference irrespective of the skill or length of service of the coloured workers. Of the remaining twenty-two respondents, nineteen stated that the coloured man should be given preference if he was more skilled or had worked for the flrm longer, and three were undeclded. This would suggest that white workers would be less prepared to accept new coloured workers in times of unemployment, but would not insist on existing coloured employees being made redundant first. Of course, it may be that the white workers would have been less impartial in a group situation, say at a union meeting. However, the fact that, with the exception of Castle Iron Co., "last in, first out" seemed to be the generally accepted policy in cases of redundancy tends to support the interview responses.

c) Pactors Causing Resentment of Coloured Workers

We noted above that although most white workers accepted coloured immigrants as work-mates, they did so with some reservations. The majority, other things being equal, would have preferred to work where only white people were employed. What then were the reasons given for this preference?

The most common source of complaints concerning coloured workers was the general question of health and hygiene, particularly with respect to their alleged misuse of toilets. Management in 37 out of a total of 78 firms (interview and questionnaire surveys combined) and 9 out of the 25 white workers 
interviewed stated that difficulties over the "toilet question" had been experienced. Such complaints occasionally occurred with respect to West Indian workers, but in the main, the difficulties were attributed to the different sanitary habits of Asians. As will be seen in Table 22, complaints concerning misuse of toilets occurred to a much greater extent in firms employing Asian workers than in those employing West Indians only.

\begin{tabular}{|c|c|c|c|c|}
\hline Table 22 : & $\begin{array}{l}\text { Occurrenc } \\
\text { of Toilet }\end{array}$ & Complail & concerning & Misuse \\
\hline \multirow{4}{*}{$\begin{array}{l}\text { Reported by } \\
\text { Management } \\
\text { Reported by } \\
\text { White Workers }\end{array}$} & \multicolumn{2}{|c|}{ Firms Employing Asians } & \multicolumn{2}{|c|}{$\begin{array}{l}\text { Firms Employing West } \\
\text { Indians only }\end{array}$} \\
\hline & No. & Total & No. & Total \\
\hline & $33(55 \%)$ & 60 & $4(22 \%)$ & 18 \\
\hline & 9 & 18 & 0 & 7 \\
\hline
\end{tabular}

The Labour Officer of Westwood Foundry summed up the problem as follows:

Asians wash rather than wipe, squat rather than sit. The result is feet marks on the seat and milk bottles being taken into the toilet.

A further difficulty reported in other firms was that the Asians would refuse to clean toilets because of religious taboos. This naturally caused resentment amongst the cleaning staff. The Labour Officer of Edge Tools Ltd. stated: 
The firm has had some trouble on this question. If they cause a mess you cannot order an Asian to clean it up because he would leave. On the other hand, it is not fair to expect the cleaners to clear up after them. Periodically the cleaners complain. I try to placate them the best $I$ can and promise to do something about 1t. I then make a fuss about it to the Pakistani workmen, but there isn't anything I can do really. It is a very difficult problem.

In Omega Metals Itd. hygiene was described as "the biggest bug-bear" in the employment of Asian workers, and in Regal Manufacturing Co. the Personnel Manager stated that, in general, East Indians were not employed because they were "not too clean in their personal habits." The Labour Officer of Brierley Metal Works stated that the toilet problem was a most important question:

If a man doesn't settle down, you can sack him. It is more difficult to find out whether he is using the toilet properly or at all.

In Precision Engineers Itd., according to the Personnel Director, the sanitary habits of Pakistanis were "the only major factor causing friction between white and coloured workers." An employee representative on the Workers' Council stated that the toilet question was beginning to cause trouble amongst the men and suggested that a note should be put in the wage packets of the coloured workers explaining the situation. This woula hardly have had the desired effect; the majority of Pakistanis in this firm could not speak let alone read English and amongst 
the West Indians it would simply have caused resentment. A Personnel officer in the same firm stated that management were at their wits' end to know what to do: the only logical solution was to provide separate tollets, but they did not want to do this because they were strongly opposed to segregation. In other firms, however, this dilemma had been avoided. The Labour Officer of Westwood Foundry stated:

Because of the expansion of the labour force, new conveniences were needed. A new ablutions block was bullt to cater for the Basterner without segregation or discrimination. Asiatic tollets were provided as well as the ordinary British ones. The rule is that anyone can use anything provided he uses it properly. Anyone, white or coloured, not using them properly goes up the drive. 1

Similarly, the Labour Officer of Brierley Metal Works said that Aslan-type toilets had been provided because the coloured workers had different habits. There was no restriction on the use of European-type toilets, but the Asian workers preferred their own kind. This he stated had improved race relations considerably.

In all, Asian tollets had been installed in six firms $^{2}$ and were about to be installed in another $\mathrm{firm}^{3}$ at the time the

1. 1.e., is dismissed. However, on the one occasion an Asian had been caught misusing the toilets he had been dismissed but allowed to return to work two weeks later. The Labour officer added that the provision of Asiatic tollets had not got round the milk bottle problem. However, the use of bottles had been prohibited and the Asians now used cubes and "squeezy" jars for oiling purposes.

2. Firms 2, 6, 7, 8, 12 and 13.

3. Firm 14. 
interview surveys were carried out. With the exception of Edge Tools Ltd. (see above), this solution had met with a large measure of success. In two firms, however, management were opposed to the provision of Asian toilets. The Personnel Officer of Grange Graphite Co. said that they had been advised by a race relations body to provide Asian toilets, but had refused to do so. Instead they had threatened firing if the tollets were not used properly, which had worked to some extent. In Soverelgn Steel Works the Personnel Manager stated:

We haven't provided Asian tollets and we have no intention of so doing. They must adjust to our standards, just as we would have to adjust to theirs if we visited their country. To be blunt about the matter, we did not ask them to come here and so if they do come, they must use our standards. It's not too much to ask is it? They can't expect us to provide facilities to fit in with them.

In other respects, however, the above respondent was most sympathetic concerning coloured workers and the problems they faced.

Although misuse of toilets was the most common objection to coloured workers, the question of hygiene also gave rise to other complaints. These included body odour, ${ }^{1}$ breath odour, ${ }^{2}$ spitting, ${ }^{3}$ bringing disease into the country, ${ }^{4}$ and so on. Whilst these complaints may be justified in some cases, there also

Mentioned by five managers and two white workers.

2. Mentioned by one manager and one white worker.

3. Mentioned by two managers and three white workers.

4. Mentioned by one manager and five white workers. 
appears to be a tendency for a higher standard of cleanliness to be expected of coloured workers. In Precision Fngineers Itd., for example, supervisors had objected to the coloured workers because they urinated in one of the yards instead of going to the toilets. The Personnel Director pointed out to them that this was not applicable only to the coloured workers because there had been complaints about the white workers doing the same thing before coloured workers had been employed by the firm. Similarly, it was pointed out in several firms ${ }^{1}$ that misuse of toilets was not confined to coloured workers. One respondent (Personnel Manager, Sterling Metal Co.) went so far as to say that Asian workers "couldn't be any filthier than British workers."

Moreover, seven managers in the interview surveys stated that the coloured workers used the bathing facilities of the firms more than the white workers. ${ }^{2}$ In Westwood Foundry, for example, the Labour Officer stated:

Whereas the British workers rush off home in their dirt, the Indians take advantage of the ablutions and get washed and changed before going home.

Apart from the question of hygiene, there were a variety of other complaints concerning coloured workers reported by management and workers. However, none of these occurred very frequently. Three managers in the questionnaire survey stated

1. Firms 8, 15, 16, 24, 30 .

2. Firms $7,9,12,17,24,26,27$. 
that the slow working pace of coloured workers (West Indians in two cases and Pakistanis in the other) had caused resentment. In one of these firins, the difficulty arose because West Indian workers did not take poorly paid piece work operations in their stride and thus caused work study investigations. However, only one of the white workers interviewed complained about the working pace of coloured workers.

With regard to the Aslan workers, there were complaints that their inability to speak English gave rise to difficulties (six white workers), that they "grabbed" components before anyone else when working on piece work (three white workers) and that they were a danger to other workers (two wh1te workers). Three white workers complained that they would work for low wages and thus take the white man's job or ruin his bargaining position. In two cases (both in Omega Metals Ltd.) there would seem to be some justification for these accusations (see pages 313-316), but the third white worker admitted that undercutting did not take place in his firm (Edge Tools Ltd.). Finally, a worker in Steel Bars Itd. complained that Arab workers did not have to pay income tax. He stated:

These Arabs don't pay any tax. They all claim for seven or eight kids back in Aden. It's not right you know. They are living and working in this country and working along side people who have to pay tax, so why shouldn't they pay tax as well. They only have to put in a couple of "double ones" and they get paid more than a man who is more skilled than what they are. It's worth while for them to 
do double shifts because they get all the money, so they'll do one anytime you ask. You ask a white bloke to do a double shift and he'll say "Not likely they'll only take it off me again in tax." It's not fair you know, something ought to be done about 1 t.

Resentment concerning Asian workers not paying income tax was also mentioned by managers in four interview survey firms ${ }^{1}$ and complaints concerning language difficulties were reported in two firms in the questionnaire survey.

Objections to coloured workers in general included taking white workers' jobs (four white workers), touchiness (two white workers ${ }^{2}$ ) and living off the dole (three white workers). In some cases, however, the white workers made an obvious attempt to see the coioured workers' point of view. One, for example, stated that with work slacking off they ought to go back to their own country, but added that of course it wasn't much use them going back if there was nothing to do there. Another, after complaining that coloured workers lived off the dole, stated:

Of course, a lot of firms won't employ them. If I left here I could get a job straight away. I wouldn't have to go on the dole. But they probably wouldn't be able to get a job.

1. Firms 22, 27, 28, 29.

2. In both cases the coloured workers referred to were West Indians. 
Finally, there were some indications that attitudes towards the coloured immigrant as a worker were influenced by relations in the community setting. In three firms ${ }^{1}$ managers. claimed that the main objections to coloured workers arose not from relations at work but from resentment of their living conditions, One stated:

I should say that $75 \%$ of white workers are against coloured workers. This is not the working environment but the domestic environment and naturally it percolates through to works attitudes.

(Production Services Manager, Blackford Rolling Mills)

In the interviews with white workers, one respondent objected to coloured workers on the grounds that they seemed to obtain council houses much more easily than white people and a further five respondents objected to the living conditions (noise, overcrowding, etc.) of coloured people.

In spite of the above complaints about coloured immigrants, however, there appeared to be relatively little overt friction between British and coloured workers in the firms under consideration. In fourteen firms managers specifically stated that no friction had occurred and in a further eleven firms none was mentioned. In the remaining firms experience varied. In Major Castings Ltd, the Personnel Manager stated that there was occasional friction due to individual prejudice on the shopfloor, and in Brierley Metal Works and Components Ltd., there had 
been occasional fights but, according to the managers concerned, these had been on an individual rather than a racial basis. In Soverelgn Steel Works, the Personnel Manager stated, there was a tendency for some white employees "to take liberties with the coloured workers - to push them around." On occasions, this had led to fights and management had sacked the white worker and kept the coloured man - despite objections from the white workers in general - when they had felt that the fight had been caused by someone picking on a coloured man.

In Westwood Foundry, on the other hand, where a number of fights had occurred when coloured workers had first been employed, there was a strict rule that any fighting would result in the dismissal of both parties. According to the Labour officer:

The causes of the fight are not judged and there is no question of whose fault it was - both are out. Th1s is because any judgement of blame would result in people gathering on both sides, and you might get two countries, each blaming the other, which would be too unwieldy to handle.

However, there had been little recent friction in this firm. The Labour Officer stated:

Apart from little irritations and one or two fights one needn't even mention, white and coloured get on well together and work well together.

Finally, in Steel Bars Itd. there had been a fight between a British worker and an Arab which had resulted in the 
Britlsh worker being taken to hospital to have stitches put in a cut. The Arab was sent home for the day to allow tempers to cool. However, before he left for the hospital, the British worker told management that he did not want the Arab sacked as the fight had been entirely his own fault, and the two men shook hands the next day,

\section{Social Relations Between White and Coloured Workers}

\section{a) The Level of Social Integration}

From the discussion thus far it will be apparent that In spite of various obstacles such as the reluctance of firms to employ them, language difficulties on the part of Asian immigrants, their generally lower level of skill and so on coloured workers had achieved a relatively high degree of work integration in the firms under consideration. Though to some extent confined to the lower jobs, they had fitted into and become established as part of the formal organisation; they were in general accorded equal treatment by management and accepted as work-mates, albelt with some reservations, by the white employees. When we come to examine social relations, however, a quite different pattern emerges. Whilst there was some variation both between and within firms, the general level of social integration was comparatively low.

It was possible to obtain adequate data on the pattern of social relations between white and coloured workers in only twenty-six of the thirty-one interview survey firms. In 
sixteen of these firms, ${ }^{1}$ managers stated that white and coloured workers tended to remain in separate social groups when not actually working together. Examples include:

Personal relations are non existent. They will work together when necessary, but after that it's finished.

(Personnel Manager, Muirhead Foundry)

They mix during work, but they tend to segregate during lunch-breaks.

(Works Manager, Annerley Iron Foundry)

The Englishmen don't want the coloured workers and they don't want the Englishmen ...... They certainly don't mix at all. You never see English and coloureds sitting together on the company 'bus. You don't see them walking down the yard together either. The situation hasn't changed at all since 1956, and it shows no sign of changing.

(Personnel Manager, Grange Graphite Co.)

There's nothing said, but the coloured workers don't go in to eat with the white workers. They sit around a stove in the works. They use the showers whereas the whites don't.

(Works Manager, Stalnless Steel Itd.)

1.

Firms 2, 6, 7, 10, 12, 14, 15, 16, 17, 18, 21, 22, 23, 25, 26 and 30 . 
In the remaining ten firms ${ }^{1}$ some degree of social integration had taken place. Often, however, the level of integration varied either between different coloured groups or between different social situations.

In Leigham Cannery, accoraing to the Personnel officer, there was "very good integration" between the white and coloured women, but the men tended to remain in separate groups. In Precision Engineers Ltd. it was reported that West Indians were in general well liked, whereas the Pakistanis, most of whom could not speak English, were less popular. Similarly, the Personnel Manager of Sterling Metal Co. stated that the Pakistanis kept to themselves, whereas the other coloured workers, Arabs and Somalis, mixed quite well with the white workers. This was supported by a Departmental Manager in Polton Rolling Mills who claimed that Arab and British workers mixed very well and were very friendly, but the Pakistanis tended to keep apart. In both firms, however, all the coloured workers tended to remain in their own national groups at meal times.

In Steel Bars Itd., on the other hand, white and coloured workers ate and played cards together at the same tables in the canteen. There was, according to the Works Director, "a fair bond of friendship between them." On one occasion there had been a fight between two British workers, and before anyone else could intervene, the coloured workers had separated them and were holding them back. This incident is highly 
significant in that it shows that the coloured workers were sufficiently sure of their status to "interfere" in a private quarrel. In spite of the close relationship at work, however, the coloured workers did not, in general, join in the works social outings. The main reason was that, as Moslems, they neither smoked nor drank, and the latter, according to the Works Director, constituted a considerable social handicap on such occasions.

By contrast, quite a few of the West Indian workers employed in Drop Forgings Ltd. went on works outings, according to the Personnel Manager. In Ensign Spring Co., however, where the coloured workers were also West Indians, they participated in works social activities only to a limited extent. Although socially accepted within the works environment, coloured women took no part in any of the outside social activities and the coloured men participated only in out-door events such as cricket. Neither used the works social club. The Personnel Manager thought that this was a good thing; he did not like the idea of white and coloured people drinking at the same table because 1t "might lead to trouble." In City Transport, on the other hand, the coloured workers did use the social club. Here white and coloured played dominoes and snooker together and the relationship between them was said to be very good. In general, however, white and coloured workers tended to segregate when eating.

In Hamilton Engineering Co., according to the Labour Officer, there had been no difficulty in integrating white and 
coloured workers; they had mixed very well and in one case the white workers had bought a West Indian a leaving-present. The West Indians' passionate love of cricket, he claimed, had made a significant contribution to their integration, particularly during the West Indies Test Series.

The West Indians take part in works sports matches, especially cricket. We don't have any who are good enough to play in the works team, but they do play in inter-departmental matches. This usually entalls a night out in the pavilion afterwards and they have mixed very well. All th1s helps without a doubt. It causes social groupings when they have things in common.

The attitude here, it will be noted, differs considerably from that expressed in Ensign Spring Co. (see above).

Finally, in Pentland Alloys Itd. coloured workers were soclally integrated at work, but no data were obtained concerning their participation in works social activities, or whether indeed such activities were organised in this firm.

To summar1se: in contrast to work integration, only a relatively small degree of social integration had taken place in the firms visited in the course of the interview surveys. Adequate data concerning social relations were obtained in twenty-six firms: in sixteen firms white and coloured workers tended to remain in separate social groups when not actually working together and whilst social integration had occurred to some extent in the remaining ten firms, this was often limited to certain coloured groups or to certain social situations. 
How then are we to account for this situation? Part of the answer undoubtedly lies in the attitudes of the white workers. In the questionnaire survey, the evidence suggests that the level of social acceptance is lower than that of work acceptance. Although there had been an initial resistance to the employment of coloured workers in some cases, they were accepted as work-mates in $94 \%$ of firms by the time the present research was carried out. By comparison, only in $57.5 \%$ of firms (23 out of 40 ) was it stated that coloured workers were accepted socially. Similarly, in the interview surveys, although attitudes towards immigrants ranged from highly favourable on the one hand to highly unfavourable on the other, white workers were in general less inclined to accept coloured workers in social as opposed to work relationships.

Even in the realm of social relationships, however, it is somewhat of an over-simplification to describe the situation in terms of a single level of acceptance or rejection. As with work acceptance, there were indications that the level of social acceptance varied under different circumstances. Firstly, West Indians tended to be accepted in social situations to a greater extent than Asian workers. The general level of social acceptance was considerably higher in firms such as Hamilton Engineering Co, and Pentland Alloys Ltd, where only West Indians were employed, while in firms where both West Indians and Asians were employed, white workers were, in general, more prepared to mix socially with West Indians, However, the evidence of the questionnaire survey is far from conclusive. Although white 
workers were more willing to accept West Indians in nine firms compared with only two in which Asians were preferred, it was stated in the remaining seventeen firms answering this question that there was no difference between the different coloured nationalities with respect to the level of social acceptance. Secondly, social acceptance appeared to be higher the fewer coloured workers there were. In Precision Engineers Itd. a Personnel officer stated that when only a few coloured workers had been employed, they had been great favourites and had almost been "adopted" by the white workers. Later, when the number of coloured workers had increased, relations between white and coloured workers had tended to become less close. In several firms, it was found that when there was only one coloured worker in a department or work group, he tended to be accepted to a much greater extent than when there were even, say, four or Pive. In Pentland Alloys Ltd., for example, a white worker stated that the one coloured worker in his shop mixed socially with the white workers, but on other shifts, where there were more of them, they tended to "mix more with each other rather than with whites." Similarly, in Torrington Cutlers, a West Indian, again the only coloured worker in the shop, was accepted by the white workers whereas the others, tended to remain in their own social group.

Finally, there were indications that the degree of social acceptance varied in different situations. We noted in the previous section that in several firms white and coloured workers mixed during work, but tended to separate on other 
occasions. In other firms, where in general little social integration had occurred, a similar pattern could still be found. In Annerley Iron Foundry a white worker stated:

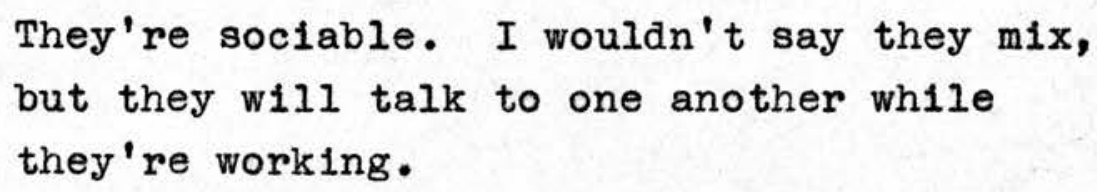

Similarly, in Ridgeway Steel Co., where the majority of coloured workers were employed in work groups under a white supervisor, a shop manager said that white and coloured workers never ate together and never sat together, but they did laugh and joke together sometimes when their work brought them into proximity with each other.

However, one coloured worker in this firm, a boiler firer who was employed in a team with white workers, was said to have "very cordial relations" with his white work-mates. Of course, this may partly be due to the fact that the coloured worker in question was more prepared to mix socially with white workers because there were no other coloured workers in the group. Nevertheless, there did seem to be a tendency for coloured workers to be accepted to a much greater extent, both socially and as workers, where they worked with white workers on the same job, either as the mate to a skilled man as in Pentland Alloys Ltd. and Stalnless Steel Ltd., or as members of the same work group as in the rolling teams in Steel Bars Itd. and Soverelgn Steel Works.

However, the most noticeable difference in the level of social acceptance was between the work and the community 
environment. One manager ${ }^{1}$ went so far as to say that "Any friendship between white and coloured ends at the works gate." As a generalisation this appears to hold true for the majority of white workers interviewed during the present research. Even those white workers who were willing to accept coloured immigrants as friends at work were, in the main, unwilling to do so outside.

I wouldn't go out of my way to avoid them I do talk to them when I see them out - but

I prefer my own countrymen as personal

friends.

\section{(white worker, Le1gham Cannery)}

No I wouldn't really accept a coloured worker as a friend outside the works. If I saw my mate, I would acknowledge him but

(white worker, Pentland Alloys Ltd.)

In some cases white workers had mixed socially with their coloured work-mates outside the works, but this tended to be seen as an exception to a general rule.

I would accept a coloured man as a friend inside the works but not outside. I have taken my mate to a boxing match in Manchester and things like that, but I don't mix with them in general.

(white worker, Pentland Alloys Ltd.)

I shouldn't really pal with them. Well we have done on occasions - we have taken 
one or two on works trips - but not usually.

But these we have here are exceptional.

(white worker, Steel Bars Itd.)

Where coloured workers were not accepted socially at work, rejection of them in the community environment tended to be much more vehement.

I wouldn't live beside them. Once my day's work's done, I don't want anything to do with them. I wouldn't want to make friends with one outside the job.

(white worker, Omega Metals Itd.)

A Jamaican has moved in near my house. A neighbour has moved out and I shall have to move soon. It w1ll become a slum area radios going all the time. If I had the money, I would go to Australia or New Zealand where they're not permitted.

(white worker, Omega Metals Ita.)

Nevertheless, one exception should be noted. A white worker in Leigham Cannery who was unwilling to accept coloured immigrants at work - mainly on the grounds that they were taking jobs from white people - was much more willing to accept them in the community environment.

I should be friendly outside, but I don't want one working with me. Outside is different from working with them.

The respondent did, in fact, have one coloured friend outside the works. He stated: 
There's a West Indian that I have a drink with in the -... Hotel. He's a real nice chap - a grand fellow in every respect. But he's the only one I come into contact with.

The existence of these varlations in the level of social acceptance leaves us with two problems. Firstly to explain why it was, in general, relatively low; and secondly to explain why it varied under different circumstances.

Amongst white workers, the main reason given for the relatively low level of social integration at work was the fact that coloured workers came from a different cultural background and thus had, to a greater or lesser extent, different customs, values and interests. The question of differences in values occurs in the theories of both Richmond (1957) and Carey (1956). However, both place much emphasis upon the beliefs of white people concerning the different sexual values of Negroes. Richmond states, for example, that insecurity amongst whites who are uncertain how to behave towards Negroes is "aggravated by the belief that coloured people have different values, especially with regard to sex." Similarly, Carey suggests that the stereotype of the Negro as a sexually uninhibited and highly potent being, constitutes a threat to British values in matters of sex. Whilst such beliefs may have some relevance in the community environment, in the present research there was little to suggest that they influenced attitudes towards coloured 
immigrants at work. Only rarely did the question of sex arise, and even in these cases the evidence was inconclusive.

In only one of the interview survey firms was it suggested that matters relating to sex had influenced the British workers' attitudes towards coloured immigrants. The Production Services Manager of Blackford Rolling Mills stated:

There seems to be more resentment against the Pakistanis than the others. They appear to have worse living conditions and appear to get away with more things. The Pakistanis are notorious for their relations with girls. Our workers have high average age and have daughters of their own and therefore there is resentment. And in one or two cases the daughters have been involved with Pakistanis.

Unfortunately, it was not possible to interview the white workers in this firm and therefore confimation of this statement could not be obtained. However, it will be noted that whereas the theories of both Carey and Richmorid are concerned with Beliefs about the sexual values of Negroes, the resentment in this case was directed against Pakistanis. Amongst the white workers interviewed, only one mentioned the matter of sex in relation to coloured workers. A white worker in Pentland Alloys Ltd. stated:

I can't stand talking smut with coloured chaps about white women. Some of them (other white workers) delight in it, but I don't think 1t redounds to anybody's credit. Their sense of humour is different and I don't think it is a good idea to talk that way with them. My mate is all right. He doesn't talk smut. 
Even here, however, the respondent's concern over this matter did not appear to influence his attitude towards coloured workers unduly. He was, in fact, quite favourably disposed towards coloured immigrants; he stated that he would not prefer to work where only white people were employed, spoke very highly of his West Indian mate, and was one of the few white workers who was not in favour of immigration restriction. The question of sex received no more emphasis than many other topics he talked about during the interview and the stereotype that the coloured worker's sense of humour in relation to sex was different - was in any case relatively mild. He did not, for example, suggest that sexual behaviour was different or even that all coloured workers "talked smut". Moreover, he blamed the white workers for encouraging their coloured workmates to "talk smut" about white women as much as he blamed the coloured workers themselves. 1

During the management interviews, however, there was one case in which a highly unfavourable attitude towards coloured workers occurred in conjunction with stereotyped bellefs concerning coloured people and extreme prejudice in matters of sex. The respondent in question was the Departmental Manager in Soverelgn Steel Works whose views we have already discussed in Chapter Seven. This respondent, it will be remembered, stated that coloured people were dirty and uncivilised in their own countries and that he could not stand the idea

1. The further point arises that if, as the respondent claimed, the coloured workers were encouraged to "talk smut" then it would appear that at least some of the white workers did not object to the coloured workers discussing their experiences with white women. 
of white women going out with coloured men. He also claimed that coloured workers were "an ldle set of black bastards" and yet later denied that he had said that they were not good workers. It seems likely, therefore, that the respondent's adverse assessment of coloured workers was motivated by prejudice, in which sexual rivalry was a major factor, rather than any objective appraisal of their work performance. By contrast, a foreman in Soverelgn Steel Works who was also unfavourably disposed towards coloured workers appeared to have a quite tolerant attitude towards mixed marriages. The respondent stated that $80 \%$ of coloured workers were no good and yet spoke with considerable sympathy of one particular coloured man, a Somali, whose white wife had left him. He was highly critical of the woman concerned who had, he stated, deserted the Somali although he had provided her with "a good home and everything a girl could ask for."

Thus 1t would appear that beliefs concerning the sexual values of coloured people do not play a major role in determinIng attitudes towards coloured Immigrants at work. The vast majority of respondents did not mention the subject and amongst those who did the evidence was contradictory.

More important than beliefs concerning particular values seems to have been the image of the coloured man as a stranger someone unacquainted with British norms and values in general. This seems to have been at the root of much of the initial resistance to coloured workers reported in several firms. 
We had quite a lot of difficulty getting coloured workers accepted at first. At that time it was something new ......It was just the fact that they were a different nationality.

(Shop Steward, Major Castings Ltd.)

In the early days, there was a certain amount of natural resentment at the chargehand level. This was probably just because they were different. Over time, particularly when they go to know them as individuals, this began to break down.

(Personnel Officer, Leigham Cannery)

When the blacks first cams, they (the white workers) were afraid of them. There wasn't any trouble between them, but they were afraid of them - some of them were hot-heads.

(white worker, Steel Bars Ltd.)

Actually, when they first came, I didn't fancy the idea, but it's turned out all right. It was just that strangeness you know.

(white worker, Pentland Alloys Itd.)

As we have already noted, and as the above examples indicate, this initial resistance to coloured workers tended to diminish in time. The white workers became accustomed to the coloured immigrants, sufficiently at least to accept them as workers, and in some cases friendships developed. The last respondent above, for example, in spite of his initial misgivings 
over the employment of coloured workers, said of his West Indian mate during the interview:

He's one of the nicest personalities I've ever met. He takes everything in his stride. You can't help but like him.

More often, however, the white workers' image of the coloured immigrant as a stranger seems to have inhibited the growth of close social relationships.

This was particularly so in the case of Asian workers, where the desire to maintain social distance was often attributed directly to differences in cultural background.

It's not a matter of colour - it's their way of life.

(white worker, Omega Metals Ltd., with respect to Pakistanis)

Myself, I can tolerate them, but I can't be friendly towards them. If you're friendly they take advantage of the fact. If they would change their ways and habits, there would be no difference.

(chargehand, Edge Tools Ltd., with respect to Indlans and Pakistanis)

They're different. They have different habits, different religion, different hygiene.

(Shop Steward, Major Castings Ltd., with respect to Pakistanis)

West Indians, on the other hand, tended to be regarded as being less different from British people and therefore easier to get on with and easier to understand, both in terms of 
language and motivation. This seems to have been the main reason for the relatively higher level of social acceptance of West Indians noted above.

I would rather have the Jamaican. He has the same way of life. He eats the same way as you do. He speaks the same language. When in Rome do as the Romans do - if you want to get on with him.

(white worker, Omega Metals Ltd.)

They're too sly and olly for me. You can see 1t when they look at you, in their eyes. It Isn't the Jamaicans I'm against - there are some decent chaps amongst the Jamalcans It's these Indians.

(white worker, Edge Tools Ltd.)

West Indians are all right - they do know our language. I would prefer them to Arabs or Pakistanis. The West Indians, they understand. The Arabs and Pakistanis, maybe they understand - when they want to. They're not out in the open like the West Indians. (white worker, Le1gham Cannery)

The Jamaicans seem to be the easiest going. Some Pakistanis seem a bit moody.

(white worker, Le1gham Cannery)

Nevertheless, there was still a tendency for West Indians to be regarded as being, to some extent at least, strangers. A supervisor in Omega Metals Ltd., for example, stated that he preferred West Indians because their way of life was more similar to his own up to a point. In Pentland Alloys Ltd. a 
white worker spoke of some West Indians appearing to have come "straight from the jungle." He stated:

They come over here with remarkable ideas. One of them was a voodoo worshipper - he went off the rails eventually ..... One thing I get on to them about is the way that they jabber when they get excited. I have to tell them to slow down so that I can understand what they're talking about.

Another white worker, in Leigham Cannery, was under the impression that English was not the West Indians' native language. He thought that they were taught it in the schools. Similarly two West Indians in Hamilton Engineering Co. commented, somewhat ruefully, that some English people were surprised that they could speak Inglish so well.

Apart from the fact that white workers tended to regard coloured immigrants as being strangers, however, there is also evidence to suggest that they regarded them as being of lower status. One indication is the greater reluctance to accept coloured workers in the higher status jobs and particularly as supervisors. ${ }^{1}$ Another is the reluctance, noted in Drop Forgings Ltd., to work for a firm which has acquired the reputation of being a coloured works. ${ }^{2}$ A third is to be found in a report

1. In this context, it is interesting to note that one of the respondents in Edge Tools stated that he would accept a coloured university student in a superior job, but not a coloured worker from the shop-floor. As he obviously would not have required such high qualifications in the case of a white worker, this provides an apt illustration of the thesis that the coloured man has to go one better in order to obtain an equal position. 2. Both the above points are also made by Sheila Patterson (1963) see page 107. 
of one of the questionnaire firms that "The white worker expects higher earnings than the coloured man despite the fact that they may be dolng the same job."

Furthermore, there was a tendency amongst white workers to regard themselves as being better workmen then the coloured immigrants. Among the twenty-five white workers interviewed, twelve thought that coloured workers were slower to learn than British workers, eighteen that they showed little initiative, ten that they were less intelligent than British workers, ${ }^{1}$ and sixteen that they required more supervision. After the first eleven interviews, a further question was asked regarding the sk1ll level of coloured workers. Ten respondents stated that they were less skilled than British workers, three that they were "about the same" and one gave a non-committal answer. This is not to say that these respondents had a uniformly low opinion of coloured immigrants as workmen. There was a considerable range of opinion and some of the answers were quite favourable. Nevertheless, all but two of the twentyfive respondents stated that coloured workers were inferior to white workers in at least one of the factors we have considered -

1. It is doubtful, however, whether some of the respondents clearly distinguished between intelligence, per se and other factors such as education, cultural background, or merely ability to cope with working in British industry. One, for example, stated that some coloured workers had become more intelligent since joining the firm, but most of them still couldn't speak English; another stated that West Indians were more intelligent than Asians, having been taught English at school; whilst a third said that coloured workers who had lived in towns and been to school would be more intelligent than those who had been in agriculture. 
skill, speed of learning, initiative, intelligence and supervisory requirements - and none said that they were superior. Some further comments made during the interviews also suggested that the white workers felt that they had superior status.

These blokes here, cheap labour that's all it is. They have a low standard of living In their own country ...... The boss would like to bring us down to their level if he could.

(Omega Metals Ltd.)

Some of the coloured workers on night duty work very hard. Mind you, when you've finished, they're only doing woman's work. Women do their jobs in the day time. (Leigham Cannery)

I don't think a white man would come and do the kind of jobs they get ..... There Isn't so many white labourers now; they are mainly black men.

(Hamilton Engineering Co.)

Some of the Arabs are pretty docile a blt like little kids.

(Steel Bars Ltd.)

You've got to use your patience to teach them because coming to work over here must be a terrible jolt to these kids. (Pentland Alloys Ltd.)

However, it is not sufficient merely to show that the white workers belleved that coloured immigrants were of a lower 
soclal status, we must also demonstrate that these beliefs affected the level of social acceptance. The evidence here is mainly of an indirect nature. As we noted in Chapter Two, Banton (1959) suggested that British people were not sure of the correct norms of conduct concerning coloured immigrants, mainly because the latter refuse to enter into relationships in the role of a social inferior. There were several indications in the present research that the white workers experienced some difficulty in achieving a pattern of behaviour in relation to coloured immigrants which was acceptable to both parties.

In Major Castings Ltd, a shop steward stated:

I've always found it best to lean cver backwards to be falr. They've had preferential treatment. We have always been very careful not to give them the chance to claim that they were not getting fair treatment because of their colour.

Similarly, in Torrington Cutlers, the Works Director sald of the white workers:

They will sometimes be particularly nice to the coloured workers. More so than they would be to their own colleagues under the same clrcumstances ..... This would appear to be a special attempt not to be condescending to the coloured people.

In the same firm a white worker stated:

We always have the difficulty that when we try to tell them anything, they think we are trying to impose on them .... The chap 
in our department has come with a chip on his shoulder. His attitude is that, when we are trying to teach him anything, we are trying to take advantage of him.

Nevertheless, the respondent stated that, in a way, he got on very well with the coloured worker concerned.

He resents being pushed around, but he looks upon me as a father confessor in a way. Anything he doesn't understand, he'll come and ask me.

Th1s suggests that as long as the coloured worker was prepared to accept the role of a social inferior, asking for advice, he was accepted, but resentment arose when he refused to accept this kind of relationship. Further evidence to this effect was found in other firms. In Precision Engineers Itd., it was stated that West Indians were very popular because they could be kidded, e.g., on how many wives or children they had, the coloured workers accepting such kidding with good humour. However, the fact that West Indians were sometimes able to buy a car (a symbol of status) by clubbing together, caused resentment amongst the white workers who could not afford one. In one of the questionnaire firms, where Indian workers were not socially accepted, it was said that resentment arose because they "aped superiority" over the white workers. On the other hand, In Steel Bars Ltd., where the Arab workers were accepted socially, a white worker stated:

I'll say this for them; if you do them an act of kindness of any kind, they do appreciate $1 t$. 
Finally, there were two cases in which white respondents were very favourably disposed towards particular coloured workers because they accepted the role of a coloured man. In Pentland Alloys Ltd. a white worker stated:

We have had incidents - one in particular is very touchy - if you snap at them, they say it's because they're coloured. My mate knows he's coloured. We had seen something on television about coloured Americans, and he said, "Well I'm a coloured Englishman" and I said, "Or course you are." ....... He's a great kid, my mate, but we've had some funny ones. He doesn't interfere. I like him.

And in Sovereign Steel Works a foreman stated with respect to a Somali:

You couldn't hope to meet a nicer bloke. We know $80 \%$ of them's no good, but he's a real good bloke. One thing about him, he knows he's coloured. You can say to him: "Why don't you come in early one morning and we'll take a scrubbing brush and see if it will come off," and he sees the joke and laughs with you.

Thus far, we have been concerned mainly with the attitudes of the white workers. As the above examples indicate, however, the attitudes of the coloured workers are also of vital importance in determining the pattern of intergroup relations at work. In the questionnaire survey respondents were asked whether the coloured workers showed willingness to mix socially with white workers or seemed to prefer to keep to themselves. The following 
answers were received.

\begin{tabular}{|l|c|c|c|}
\hline & $\begin{array}{c}\text { No. of firms } \\
\text { replying for } \\
\text { each group }\end{array}$ & $\begin{array}{c}\text { No. stating } \\
\text { prefer to keep } \\
\text { to themselves }\end{array}$ & Percentage \\
\hline West Indians & 36 & 24 & 67 \\
Indians & 13 & 10 & 77 \\
Africans & 11 & 9 & 82 \\
Arabs & 12 & 11 & 92 \\
Pakistanis & 31 & 29 & 94 \\
\hline
\end{tabular}

In one firm, employing West Indians, Arabs and Pakistanis, the following additional comment was made:

Socially, the coloured workers tend to keep to themselves. This is in no way as a result of a "cold shoulder" by the whites, and is more a voluntary situation. In other words, segregation is as much the choice of the coloureds as the whites. We have a social club, membership of which is open to all employees, coloured and white, but the coloured population are not interested.

It will be noted, however, that in general the tendency to remain in separate social groups was more marked in the case of Asian workers, particularly Pakistanis. ${ }^{1}$ The main reason for this would seem to be radical cultural differences between Asian and British workers. Of primary importance, of course,

1. There were indications that Indians (see questionnaire survey results) and Arabs (see interview survey firms, Sterling Metal Co., Polton Rolling Mills and Steel Bars Ltd., page 369) were more willing to mix socially with the white workers than the Pakistanis, but the number of firms involved in each case is too small to permit firm conclusions to be drawn. 
Is the language barrier; the Asian workers do not speak English as their native language and relatively few have learned it. Nevertheless, this does not provide the whole explanation. Unlike the West Indlans, Aslan workers have their own distinct culture with customs, habits and religlous beliefs which differ markedly from those of the British workers. In the firms studied during the present research, Asian workers were in general willing to make only those adjustments to the British way of life which were necessary in order to achieve a minimum degree of integration into the work organisation. Apart from this, they retained as many of their own cultural traits as possible and therefore tended to remain in their own social groups where little or no adaptation to British ways would be required. In two firms, for example, the Asian workers' eating habits led to voluntary segregation at meal times. The situation in Bradfield Foundry has already been described in the introduction to the present chapter. Similarly, in Omega Metals Ltd., the British workers and the one West Indian employed by the firm ate in the works canteen whereas the Pakistanis remained on the shop-floor and "ate curry out of pans with chapatis."

In the latter firm, there were also indications that the Pakistanis kept apart from the white workers as a means of avolding friction. When asked how the British and the Pakistani workers got on together, the Pakistani chargehand stated that they were,

....... not friendly, but not unfriendly. They (the Pakistanis) can't speak English 
so nobody quarrels. They don't argue, they just keep working.

The greater willingness of the West Indians to mix socially may be attributed to the fact that, not only is their cultural background more similar to that of the white workers, but also, due to the "mother country" image of Britain in the West Indies, they are much more willing to seek full acceptance into British society. Nevertheless, the fact remains that in a high proportion of firms, they tended to remain in their own social groups. Part of the explanation may be that, although there were no radical cultural differences, as in the case of Asian workers, there still existed differences in interests and topics of conversation sufficient to make the West Indians feel more at ease in the company of their fellow countrymen. One white worker stated that West Indians remained in their own social groups because they had "their own things to taik about" and another stated:

\title{
It's just the ordinary talk of everyday things they can't get into.
}

It is quite possible, of course, that the white workers merely assumed that the West Indians had different interests and therefore made no effort to associate with them. However, a similar point was made by a West Indian in Torrington Cutlers who stated:

\author{
I've got on all right with white workers \\ because I like sports - football, racing, \\ cricket - so we talk about it. But if I \\ didn't have this, I wouldn't get on so well.
}


On the other hand, it would seem that the West Indians' tendency to remain with their own social groups resulted, to some extent at least, from the lack of social acceptance on the part of the white workers. When asked why the coloured workers tended to keep to themselves, a white worker in Quality Steel Co. stated :

It's not language - Jamaicans speak good English. There's some of them think and others know that they are not wanted here.

Similarly, in Sovereign Steel Works, the Personnel Manager stated:

You tend to see them sitting having a meal in a corner rather than mixing in a group. They tend to have a chip on their shoulder... .... There is a tendency to carry a constant concern about their relations with white people and it will be many years before they lose this. They carry their own colour bar about with them and tend to view our approaches a little suspiciously. They tend to meet people who do not treat them well - the odd one or two - so you can't blame them.

In its extreme form, this attitude was rarely encountered amongst the West Indians interviewed during the present research. In only two cases was any marked resentment of white workers expressed. In Torrington Cutlers a West Indian worker stated:

I'll tell you one thing I don't like. The reason why some of us have a chip on our shoulder is because people say: "Why you come here?" They think that we come here 
to steal their jobs. But the world owes everyone a living. If they came to Jamaica we would welcome them. We would not ask why they come.

And in Omega Metals Ltd. a West Indian was extremely bitter about his relations with white workers. He stated:

Well I'Il be frank with you ..... you get some of them - they're educated, but they're ignorant - they've got a chip on their shoulder. In the canteen the other day, one of them said: "If there was another war, I bet you would go back to Jamaica." I said, yes I would. If you live in a country, you ought to fight for it, but what's the point if you are just a "wog" or a "black" after the fighting has finished. The way things are going, if you were in the trenches, one of them would kill you instead of the enemy.

However, twenty-six of the twenty-seven West Indians interviewed, including the first respondent above, stated that they got on all right with the British workers. Sixteen respondents stated that they had found white workers friendly, and in two cases highly favourable attitudes towards white workers were encountered.

Well I'Il tell you, I'm finding it all right. People have treated me very well. You couldn't have expected them to be any better. Whilst I have been in this country there has been no-one who hasn't been good. We are all living just the same and working just the same.

(West Indian, Hamilton Engineering Co.) 
I get on very well with the white workers. They are very friendly. It's better than with my own people.

(West Indlan, Pentland Alloys Ltd.)

In six cases it was said that whilst the majority of white workers were friendly, there were some who were not. However, little resentment was expressed and the general attitude seemed to be that it was best to ignore any unpleasantness which occurred.

I get on all right. You will find a few who are awkward, but if you don't take any notice, it don't go far.

(West Indian, Annerley Iron Foundry)

I get along all right with them and they get along all right with me. There's a few of course that's nasty, but there's good and bad in every nation ...... You haven't got to take any notice. You might hear people say bad things, but the best thing to do is to take no notice.

(West Indian, Edge Tools Ltd.)

In only one case, however, was there any evidence that the West Indians kept apart from white workers as a result of the white workers' behaviour. A respondent in Torrington Cutlers stated:

I don't put it in their way to make any fuss. If you're working here and you don't talk to me, I just don't talk. 
Thus in general, the interviews with West Indian workers suggest that relations with white workers were much closer and more friendly than appeared to be the case in the interviews with British respondents, both managers and workers. This inconsistency, the writer would suggest, results from a tendency on the part of the West Indians to present a more favourable account of intergroup relations at work than was actually justified. This may be attributed to two factors. Firstly, the West Indians were hurt and disappointed by the fact that the level of social acceptance was lower than they had expected and therefore tended to ignore as much as possible the incidence of unfriendliness or antagonism on the part of white workers. In Edge Tools Ltd., for example, a West Indian worker stated:

I would like to say that they are friendly because they haven't treated me bad. Until they do, I would like to say that they are friendly.

And in the same firm, another West Indian said:

I would have to say that they have treated me well. I haven't had any fuss - I just get along. If somebody else have difference, that's not my business.

Thus in both cases, the respondents stated that the white workers had treated them well or had been friendly simply because they had not been actively unfriendly. Under these circumstances it seems likely that the West Indians would remain within their own groups as a means of avoiding overt social rejection on the part of the white workers. 
Secondly, the writer gained the impression during the interviews with coloured workers that the fact that the interviews were carried out within the works environment with the approval of management tended to make respondents reluctant to be critical either of working conditions or of their relations with white workers. An attempt was therefore made to arrange interviews outside work, but with little success. Ironically enough, at a meeting of a West Indian society visited for this purpose, one of the workers interviewed in Hamilton Engineering Co. approached the writer and said that he had not given an accurate account of the situation at his firm because it was impossible to do so at work. However, he refused to provide any further information, and none of the other West Indians present were willing to be interviewed.

We may now summarise our data and conclusions with regard to social relations between white and coloured workers. The relatively low level of social as opposed to work integration may be attributed both to a lower level of social acceptance on the part of the white workers and to a tendency for the coloured workers to remain with their own social groups. In the case of the white workers, avoldance of coloured immigrants in social situations seems to result from two main factors. Firstly, coloured Immigrants tend to be regarded as strangers - people unused to British ways. This is most marked in the case of Asian workers, where fundamental differences in cultural background exist. However, West Indians are also regarded as strangers to some extent; they are thought to have different 
interests and in some cases erroneous beliefs concerning their cultural background were encountered. Secondly, coloured 1mmigrants were regarded as being of lower social status. There was little evidence to suggest that this was a direct cause of avoldance of immigrants in social situations, although this may well be the case in view of the fact that the question of status seems to be an important factor in the avoidance of coloured 1mmigrants in certain work relationships. However, there was evidence that ambiguities in the status of coloured immigrants did affect the pattern of intergroup relations. Richmond (1957) suggests avoldance of coloured people arises not because they have low status, but because they do not fit Into the British system of social stratification at all. The evidence of the present research, on the other hand, suggests that if the coloured immigrant does not have a status in the British hierarchy, it is because he is unwilling to accept the one avallable to him, that of a coloured man who "knows" he is coloured and is willing to accept a lower status role.

In the case of coloured workers, the tendency of Asian workers to remain within their own social groups was attributed to the fact that their cultural background differed radically from that of the white workers and they wished to make as little adjustment to the British way of life as possible. The West Indians' way of life is much more similar to that of the white workers and in general they were much more willing to $\mathrm{mix}$ socially with them. Nevertheless, they still tended to remain in separate soclal groups in a high proportion of firms and this 
was attributed to two factors: firstly, differences in interests and toplcs of conversation; and, secondly, a reluctance to risk social rejection by the white workers. However, owing to the inconclusive results obtained from the interviews with West Indian workers, it is impossible to judge the relative importance of these two factors on the basis of the present data.

We now turn to the variations in the level of social integration found in different firms during the interview survey. The relatively low social integration of Asian workers, particularly Pakistanis, would seem to result from the fact that their cultural background differed so radically from that of the white workers. For this reason, not only were white workers less prepared to accept them socially, but also the Asian workers themselves were less willing to mix socially with the white workers. In general, the writer gained the impression that the Pakistanis were even more unfamiliar with British ways than either the Indians or the Arabs (most of whom were Adenese) which may account for the slightly higher level of social integration of the latter two groups.

The greater social integration in work groups or departments where there were few coloured immigrants may be explained in terms of a number of factors we have already discussed. Where there are relatively few coloured immigrants it follows that:

i) The actual or ascribed cultural differences will constitute less of a threat to the values of the group, as the immigrants will not be in a position to dictate the form 
these values will take.

ii) The presence of the immigrants is less likely to constitute a threat to the prestige of the group.

iii) The immigrants are more likely to be perceived as individuals rather than simply as members of a stranger group and there is therefore a greater likelihood that common ground for social relationships will be found.

iv) There will be less opportunity for the coloured immigrants to withdraw into their own social group, either because of cultural differences or because they fear social rejection.

Finally, there were the situational variations in the level of social integration. These seemed to follow a definite patterm. Social acceptance of coloured workers was higher, the more the relationship occurred within the realm of the work organisation. In general, white workers were less prepared to accept coloured immigrante socially than as workers; less prepared to mix socially with coloured workers during lunch and tea breaks than whilst actually working with them; less prepared to mix socially with them when they did not work on the same job; and were still less willing to mix socially with coloured immigrants outside the works than within.

The most tenable explanation of this occurrence would seem to be that of Banton (1959). Firstly, the British worker will tend to be less concerned about loss of prestige when his association with coloured workers is legitimised by the work 
relationship. As one white worker put it, when asked how he felt about working in a firm which employed coloured immigrants:

That's up to the firm; that's the firm's

business.

\section{(Quality Steel Co.)}

Similarly, being friendly towards coloured immigrants during the course of work does not have the same connotations as being friendly during tea and lunch breaks or outside the works environment. Contact in the first case results from factors largely beyond the control of the white worker - managerial decisions conerning the placing of employees - whereas in the latter it results from a deliberate choice on the part of the white worker concerned. Where there is a close, formal work relationship, then mixing socially with coloured workers during tea and lunch breaks may be justified by the fact that the white worker concerned is not associating with simply any coloured worker but rather with a member of his team or work group. Such considerations do not apply, however, outside the works environment where the existence of such a formal relationship would not be known to anyone observing the association.

Secondly, the more the association is based upon a work relationship, the less important will be differences in norms and values because the work relationship restricts the range of social interaction. If, for example, the association merely consists of friendly words exchanged in passing during work, then it is possible to discuss only trivial matters which are unlikely to involve underlying differences in values. Further- 
more, this provides the white worker with a greater control over the nature of the relationship. / Being friendly with coloured workers in one situation does not necessarily imply willingness to extend the relationship to other situations such as tea-breaks or outside work. Thus, differences in norms and values which might make the white worker reluctant to accept coloured immigrants in unstructured situations are less likely to inhibit friendship based on a work relationship because the white worker can employ the norms governing work-relationships to control the extent of social interaction.

4. Social Relations Between Different Coloured Nationalities

In the previous section, we saw that although white and coloured workers, in general, worked amicably together, the level of social integration was relatively low. A similar pattern emerged with respect to the different coloured groups where more than one coloured nationality was employed by the same firm. In the questionnaire survey, respondents were asked whether the different coloured nationalities:

a) readily accepted each other as work-mates; and

b) mixed socially with each other (e.g., during tea and lunch kreaks) or tended to remain within their own national groups.

The answers recelved are presented in Tables 23 and 24. 
Table 23 : Work Relations Between Different Coloured Nationalities

Accept each other as work-mates

Do not accept each other as work-mates Total

\begin{tabular}{|r|c|}
\hline No. & Percentage \\
\hline 25 & 81 \\
6 & 19 \\
31 & 100 \\
\hline
\end{tabular}

Table 24 : Social Relations Between Different Coloured Nationalities

Mix socially

Mix socially to a certain extent Remain in national groups Total

\begin{tabular}{|r|c|}
\hline No. & Percentage \\
\hline 9 & 28 \\
3 & 9 \\
20 & 63 \\
32 & 100 \\
\hline
\end{tabular}

Data concerning social relations between the different coloured nationalities were obtained in fifteen of the interview survey firms, and in each case it was stated that they tended to remain in separate social groups. This applied not only to relations between West Indian and Asian workers, but also

1. Firms 1, 2, 6, 7, 14, 15, 16, 19, 20, 22, 23, 24, 26, 27 and 30 . 
with respect to the different Asian nationalities. Some comments of the managers concerned were as follows:

There is a fair degree of mutual segregation between the Pakistanis and the West Indians. I get the impression that there is more mixing between white and Pakistani and between white and Jamaican. On the night shift, the Pakistanis and West Indians tend to work in separate teams. They seem to like it that way so we leave them to 1 t.

(Personnel Officer, Leigham Cannery)

They tend to circumscribe themselves within their own groups. Although we (1.e. management) classify Arabs and Pakistanis together, they themselves keep apart. Although of the same faith, they do not appear to get on very well together .... We have never had any real trouble, physical violence or anything like that. They just tend to ignore one another.

(Production Services Manager, Blackford Rolling Mills)

They keep to themselves. Naturally it is a question of language. You tend to see the Pakistanis grouped together in the canteen and you see the Arabs grouped together. They don't mix - they couldn't understand one another so there wouldn't be much point. They work amicably together though; we have never had any trouble.

(Labour Officer, Polton Rolling M111s)

In eight firms altogether it was specifically stated that no friction between the different coloured groups had occurred, 1

1. F1rms 1, 8, 13, 16, 21, 22, 27 and 30 . 
and in a further eight firms employing more than one coloured nationality none was mentioned by the managers interviewed. ${ }^{1}$ In seven firms, however, some friction had occurred. ${ }^{2}$ In two cases, this had largely died out by the time the interview survey was carried out. In Sovereign Steel Works, where the majority of coloured workers were Arabs and Pakistanis, the Personnel Manager stated:

We used to have trouble over religion in the early days. They have sorted this out themselves. The Works Manager got them all together and told them that if there was any more trouble, they would all be dismissed.

Similarly, in Westwood Foundry there had been some friction between Indian and Pakistanis on political and religious grounds when they were first employed. According to the Labour Manager, drastic action had put an end to it. The Indians and Pakistanis were told that they were on trial and that if there was any more trouble they would be dismissed.

In Westwood Foundry there had also been friction between Indian and West Indian workers. When they were first employed, the West Indians were split into two groups. On one shift, they were spread out amongst the other workers, and on the other they were put in two "pockets" on their own. Where they were in "pockets", according to the Labour Manager, the Indians did much more work than the West Indians and made fun of them for this reason. For example, they suggested to a supervisor that

1. Firms $3,12,15,18,19,24,26$ and 28 .

2. Firms $2,6,7,14,17,20$ and 23. 
a conveyor-belt should be built to the toilet because the West Indians were going there so often. Where they were spread out amongst the other workers, the Labour Manager stated, a fight arose because a West Indian called an Indian a "black bastard" although he was himself several shades darker. In Bradfield Foundry, as we have already noted, there had also been friction between Indians and Pakistanis, but in this case it seems to have been mainly on a verbal level. 1 Moreover, there had been no friction between the Indian and West Indian workers who tended to ignore each other. In Tool Steel Ltd., where the majority of coloured workers were Arabs and Pakistanis, there had been some friction between the different coloured groups, but again this seems to have been of a relatively minor nature. The Personnel Manager stated:

There have been isolated instances of trouble between the races, about four in ten to fifteen years. In general, we haven't had much cause for complaint. I have known foremen complain of the difficulty of putting one coloured worker with another of a different race, but it has not caused us any worry.

The Labour Officer of Brierley Metal Works, on the other hand, thought that conflict was inevitable if members of different coloured nationalities worked together. He stated that the firm used to have "a fair amount of trouble due to the mixing of races, creeds and religions." The firm had therefore placed the different nationalities in separate, closely knit groups. The

1. See page 243 . 
respondent clained that this was the only way to preserve peaceful race relations. He stated that firms who tried to keep the different nationalities together ran into trouble and that firms were coming round to the point of view that it was best to employ only one race or to keep them separate if more than one was employed.

In the questionnaire survey, an attempt was made to obtain quantitative evidence concerning this question. Respondents were asked whether they thought the best policy with regard to the employment of different coloured nationalities was to employ only one nationality, to keep the different nationalities separate (e.g., on different shifts or in different departments) or to employ and place them irrespective of nationality. The following answers were received:

\begin{tabular}{|l|c|c|}
\hline \multirow{2}{*}{ Employ only one nationality } & No.' & Percentage \\
\cline { 2 - 3 } Keep separate & 16 & 37 \\
Imploy and place irrespective of nationality & 26. & 61 \\
Total & 43 & 100 \\
\hline
\end{tabular}

It will be seen that over half the respondents thought that coloured workers should be employed and placed irrespective of nationality, whilst only one thought it necessary to keep the different national groups separate. However, a substantial minority believed that the best policy was to employ only 
one coloured group.

In only one of the interview survey firms had the number of coloured nationalities been limited because interracial friction had occurred. Omega Metals had at one time employed Arab workers but had ceased to do so because they "did not get on with" the Pakistanis. In Steel Bars Ltd., however, Arab workers had been the first coloured immigrants to be employed, and the firm had made it a policy not to employ any other coloured groups because it was thought that this might lead to racial friction.

In three further firms, more than one coloured nationality had been employed, but had been placed in separate work groups. The Personnel Manager of Sterling Metal Co. stated that Arabs and Pakistanis had been kept apart; the firm had "never tried mixing Arabs and Pakistanis in the same shop." In Major Castings Itd., a firm employing West Indians and Pakistanis, the Personnel Manager stated:
From my observation they don't mix. They confine themselves to their own people. They don't get much opportunity to mix. There has been some deliberate placing. We never put one coloured man alone in a department, and if there's two of them, they are of the same race.

Similarly, the Labour Officer of Hamilton Engineering Co. stated:
They tend to keep to themselves. It doesn't pay to mix them too much. We found that it 
was best to keep Pairistanis in one shop and West Indians in another. We have had as much of a clash between coloured and coloured as with white and coloured.

On the other hand, as we have already pointed out, in other firms in the interview survey different coloured nationalities had worked together without conflict arising. In Components Ltd., which, it is interesting to note, was situated on the same street as Brierley Metal Works, West Indians, Indians and Pakistanis were employed in roughly equal numbers. According to the Personnel officer, the different coloured nationalities were not kept separate as a matter of policy - the furnace group, for example, consisted of Indians, Pakistanis and British workers - and yet no friction had occurred. In another firm, Indians and Pakistanis had been employed in the same work groups without management realising 1t. The Labour Manager of Edge Tools Ltd. stated that when coloured workers had first been employed, it was thought that they were all Indians. It was not until an official visitor came to the firm to talk to their "Indian" workers, that they discovered that the majority were Pakistanis. Nevertheless, some of them were Indians and and the firm also employed West Indians and Arabs, yet here again there had been no interraclal friction.

Amongst the coloured workers interviewed, only one expressed any hostility towards other coloured groups. The single West Indian worker employed in Omega Metals Itd. stated:

I would work w1th Englishmen or West Indians, but not Indians or Pakistanis. I don't come 
Into contact with the Pakistanis here, but they're the people who cause all the trouble.

It makes your stomach sick, they're so

1gnorant. Before the Pakistanis came over here, a coloured chap could get a job, but they work for nothing, so $1 t^{\prime}$ 's quite likely that they (the employers) will have him. They'll do anything for less money.

In Edge Tools Ltd. one West Indian respondent said that he would prefer to work with other West Indians or British workers because he did not understand the Pakistanis very much. Another stated:

Naturally everybody would like to work with his own people. But if you get a factory where they are all mixed - Pakistanis, Indians, English - me I can get on with everybody so it doesn't make any difference.

All the remaining coloured workers, both West Indian and Asian, stated either that they had no preferences regarding with whom they worked or that they had not come across any of the other coloured groups at work.

To summarise: the avallable data suggest that the views of the Labour Officer of Brierley Metal Works concerning the inevitability of friction amongst the different coloured groups seem largely to be unjustified. In the majority of questionnaire survey firms, the different nationalities were prepared to accept each other as workers and in over half the firms it was the policy to employ and place coloured workers irrespective of nationality. Similarly, there had been no friction in many of 
the interview survey firms and only in a few cases was it the policy to employ only one coloured nationality or to place them in separate work groups.

Nevertheless, in the majority of firms, both in the questionnaire and interview surveys, the different coloured nationalities tended to remain in separate social groups. Here again, the most important factor seems to be that of cultural background - differences in values, religion, language, and so on. However, the somewhat limited data obtained in the interviews with coloured workers make it impossible to come to any firm conclusions with regard to this question.

\section{Summary}

We suggested in the introduction to this chapter that to view the pattern of intergroup relations at work in terms of a white/coloured dichotomy and even to examine the attitudes of the white workers in terms of simple acceptance or rejection was to over-simplify the situation to an unwarrantable degree. The data of both the interview and the questionnaire surveys lend considerable support to this contention.

1. The level of social integration between the different coloured groups was equally as low as between white and coloured workers, and conflict, although comparatively rare, had occurred in both cases.

2. The relatively low level of social integration in the case of white and coloured workers was due not only to a lack of social acceptance on the part of the white 
workers, but also in part to a tendency for the coloured workers to remain in their own social groups.

3. In the case of the white workers, the level of acceptance of coloured immigrants varied considerably under different circumstances. A major distinction was made between work and social acceptance, but the level of acceptance also varied within these categories in respect of a number of factors such as the nationality of the coloured workers concerned, the numbers involved, and so on. Thus any explanation of this situation must take into account not only the attitudes of the white workers, but also those of the coloured workers, both towards the white workers and the other coloured groups. A major factor, we suggested, was the question of cultural background - differences in values, language, religion, customs and so on - which led each group to prefer the company of their fellows rather than the members of other groups with whom they had relatively little in common. However, this cannot provide a complete explanation. There existed considerable similarities in background between British and West Indian workers and, although the level of soclal integration was somewhat higher in this case, there was still a tendency to remain in separate social groups. Other factors must therefore be involved.

Apart from the minor differences in interests and topics of conversation which would result from having been born and brought up in different societies, we would suggest that three main considerations are relevant here. Firstly, there was 
evidence that avoldance of coloured workers resulted in part from a belief that they were of lower social status. This I applied to Asian as well as West Indlan workers, but is of greater importance in the latter case because differences in cultural background alone were sufficient to inhibit the social integration of the Asian group. Secondly, there existed erroneous beliefs amongst white workers which led them to believe that the cultural background of the West Indians was more different than was actually the case. And finally, although the West Indlans wished to achleve full integration into British society, the possibility of rebuff from the white workers gave rise to a tendency to remain within their own social groups. 


\section{CHAPTER NINE}

\section{SUMMARY AND CONCLUSIONS}

We suggested in Chapter One that the process of integration could be regarded as the outcome of an interaction between two sets of factors - the characteristics of the migrant group and those of the receiving situation. In the industrial sphere, the characteristics which are of primary importance are respectively:

a) the skills and capabilities of the migrant group and their expectations towards the role which they are to play in the Industrial system of the recelving country; and,

b) the vacancies avallable within this industrial system and the expectations of 1 ts members towards the migrant group.

It was further suggested (Chapter Four) that the process of adjustment between 1mmigrant and host would proceed smoothly and without friction to the extent that these two sets of factors were complementary. Finally, we distinguished between four main spheres within which industrial integration may be said to take place; namely, employment level, occupational level, the treatment which the immigrants receive from managers and supervisors, 
and intergroup relations at the shop floor level. Having examined the available data, both from the literature and the present research, we are now in a position to assess within the above framework the degree of industrial integration achieved by coloured immigrants to Britain.

Although precise data concerning the skill level of the immigrants are not avallable, it would appear that they have, in general, tended to be less skilled than British workers. Amongst the different coloured groups, however, West Indians have tended to be more skilled than Asian immigrants, with respect to both industrial sophistication and their ability to speak English as well as formal industrial training. Although less skilled according to British standards, skilled workers have, in fact, been over represented amongst West Indian migrants, in relation to the skill level of the general West Indian population.

During the greater part of the 'fifties and early 'sixties, there was a considerable shortage of labour in Britain, particularly in unskilled jobs. To this extent, then, the characteristics of the migrant population and those of the receiving situation were largely complementary. The immigrants were less skilled than British workers and wished to obtain jobs in British industry, and there were large numbers of unskilled vacancies which British firms desperately needed to fill. Undoubtedly, it was this state of affairs which stimulated the large-scale 1mmigration from the Commonwealth in the post-war years. As we have already noted, however, the course of the 
integration process is not detemined by objective factors alone. The respective orientations of migrant and host towards each other must also be taken into account.

Of particular importance are the attitudes of employers in the receiving country. Berry states that in the process of assimilation one society "sets the pattern." The same may be said of the industrial sphere, where employers are in a position radically to affect the degree of industrial integration achieved by an immigrant group, simply because they have the power to grant or withhold the jobs which its members wish to obtain. Moreover, the decisions which the employers make will be based not so much on the actual attributes of the immigrant population as upon what they believe these attributes to be. In the present research cases were found in which erroneous beliefs affected employment opportunities for coloured workers. There was, for example, Ensign Springs where the Personnel Manager gave three reasons for the small number of coloured workers employed: a) they lacked the necessary skill; b) they had a high rate of labour turnover; and c) the white employees would not accept a "preponderance" of coloured workers. In fact, many of the jobs required little or no skill, labour turnover amongst the coloured workers was almost non-existent, and so few were employed that the danger of having a preponderance of them was negligible. In other cases, different managers expressed contradictory bellefs concerning coloured workers. One example 
was particularly striking. The Labour Officer of Brierley Metal Works claimed that Pakistanis were more educated than Indians whilst in Components Ltd., an adjacent f1rm, the Personnel officer claimed that Indians were more educated than Pakistanis, and both firms preferred to employ the nationality believed to be less educated. To make such sweeping generalisations about the relative educational standards of Indians and Pakistanis seems highly dublous, but even if they were justified, it is Impossible for both managers to be right.

In Chapter Four, we suggested that there are two main ways in which firms limit employment prospects for coloured immigrants. Firstly, there are the firms which will employ no coloured workers whatsoever. Considerable inftial resistance to the employment of coloured workers was found in the firms studied during the present research. In general, firms would begin to employ coloured labour only when the shortage of British or foreign white workers became so severe that there was no other alternative. In firms where no coloured workers were employed, the usual reason given was the fact that there was an adequate supply of white labour. Secondly, there are the firms which do employ coloured workers, but still restrict the jobs avallable to them; for example by employing them only when white workers cannot be obtained; by limiting their numbers to a certain proportion of the labour force (the quota system), or by employing coloured workers only in certain departments or on certain jobs.

One effect of such policies has been to limit the actual 
number of jobs available to coloured workers. Davison (1964) estimates that the average rate of unemployment amongst coloured immigrants between 1956 and 1962 was about 10\% compared with only $2 \%$ for the population as a whole. On the other hand, except during trade recessions when there is little demand for unskilled labour, the majority of coloured workers have been able to find work of some kind. Thus, perhaps a more important effect has been to limit the range of jobs available to coloured workers to those in industries most severely hit by labour shortage, and within these industries, initially at least, to the rough, heavy, less well paid labouring jobs which white workers prefer to avoid.

The question still remains, of course, as to whether such limitation of employment opportunities results from discrimination or simply from legitimate rejection of less skilled or less able workers. On the basis of the present evidence, it is impossible to assess with any degree of accuracy the relative importance of these two factors, but it would appear that both are involved. The available data in the ilterature suggests that coloured workers are, in general, less skilled than their British counterparts, but the evidence of the present study demonstrates that discrimination - whether as a deliberate policy or as a result of erroneous but genuinely held beliefs - also plays an important part.

It should be noted, however, that in the firms which do employ coloured labour, the reluctance of managers to accept coloured workers is to some extent only an initial phenomenon. 
With experience of their employment, managerial attitudes towards coloured workers of ten change considerably. As we have seen, the jobs available to coloured workers may still be limited in a number of ways, but in most firms in the present sample they had come to be accepted as a more or less normal part of the labour force. In only a few cases were their numbers restricted to an absolute minimum. In the majority of firms, coloured Immigrants (or at least those of the nationality employed) were thought to be reasonably good workers and in some cases they were very highly regarded. In general, they were not used merely as "stop-gap" labour; although the number of new coloured workers employed tended to decrease during trade recessions, existing coloured employees were, on the whole, fairly treated with respect to redundancy.

Moreover, whilst coloured workers were usually employed only as labourers at first, at least some coloured employees had later obtained semi-skilled jobs in the majority of firms, and in some cases they had progressed to skilled work. The occupational levels of coloured workers found in the questionnaire survey were lower than those of British and forelgn white workers, but comparison with the available data concerning the skill levels of coloured immigrants to Britain, suggests that relatively few had experienced occupational downgrading, and many, in fact, had achieved considerable upgrading.

On the other hand, data obtained during the interview surveys indicate that British workers are often reluctant to accept coloured workers in positions directly above themselves 
in the status hierarchy. In general, the semi-skilled jobs obtained by coloured workers were of the differentiated type; that 1s, they either did not entall authority over other workers, or, if they did, the other workers were also coloured. Although the occupational levels of coloured workers were relatively high, therefore, it would appear that they could have been even higher had the British workers been more prepared to accept them in h1gher status jobs.

Thus far we have been concerned with the level of industrial integration achieved by coloured immigrants in general. In view of the higher skill level of the West Indian group, however, It might be expected that their employment and occupational levels would also be higher. Evidence that there is more unemployment amongst Pakistanis than West Indians was found by Davison (1964). On the other hand, the unemployment level was lower amongst Indians than West Indians, and the higher unemployment amongst Pakistanis can partially be explained in terms of geographical factors.

In the present research, no overall preference for West Indian workers was found amongst the managers interviewed. There was a tendency for firms to employ either West Indian or Asian immigrants, but the number of firms employing a preponderance of either group was approximately the same. Furthermore, the occupational level of Pakistani workers was only fractionally lower than that of the West Indians and those of Indians and Arabs, although admittedly based on a small sample, were actually higher. 
One of the main reasons for this somewhat surprising result, it is suggested, lies in the differing expectations of managers towards coloured immigrants. Although opinions often varied, the main advantage of employing West Indian immigrants was generally regarded to be the fact that, owing to their greater industrial sophistication and their ability to speak English, they were easier to train and supervise. On the other hand, the main advantages of employing Aslan workers were said to be their greater diligence and amenability to discipline. Whether a firm employed one group or the other, therefore, depended to a considerable extent upon which set of characteristics were regarded as being more desirable. In the firms studied during the present research, it would appear that there were sufficient managers who felt that the Asian workers' greater diligence and amenability to discipline more than compensated for their language difficulties and lack of industrial sophistication to ensure them relatively high employment and occupational levels. To some extent, the attitudes of managers towards West Indian and Asian immigrants seem to have been based on the actual behaviour of these groups. The present data suggest that Asian workers are more prepared to comply unquestioningly with managerial instructions than West Indians, and accept much more willingly the menial jobs whlch coloured workers often obtain in British industry. These different patterns of behaviour in the industrial sphere, it is suggested, reflect the differing orientations of Asian and West Indian immigrants towards life in British society. In general, Asian immigrants do not wish 
to become fully integrated, but prefer to make only those adaptations to the British way of life whlch are necessary to achieve a minimum degree of accommodation into the receiving society's social and economic structure. Thus they tend to regard working in British industry merely as a means of making money and are little concerned with their status or even the treatment they receive in the firms in which they work. The West Indians, on the other hand, expect to obtain full integration into British society, and moreover many regard themselves, quite rightly in terms of West Indian standards, as being skilled workers, Often, therefore, they are quicker to object to what they consider to be unequal treatment or uncivil instructions, and are less willing to accept and work diligently at what they regard as being menial tasks, unworthy of their skills.

On the other hand, it would also appear that some managers ${ }^{1}$ made considerably exaggerated claims concerning the lack of diligence and amenability to discipline of the West Indian workers they had employed. In these cases, it seems likely that the respondents expected a high level of diligence and amenability to aiscipline on the part of coloured workers, and formed an unfavourable opinion of West Indian workers in these respects, not because they were so much more "lazy" or "touchy" than British workers, but because, unlike Asian workers, they did not come up to the respondents' high level of expectation. The fact that, in Edge Tools, an initially adverse assessment

1. For example, those in Bradfield Foundry, Westwood Foundry and Omega Metals, Ltd. 
of West Indian workers eventually gave way, with continued experience of their employment, to a more favourable attitude towards them, lends some support to this conclusion.

In the majority of interview survey firms, it appeared that coloured workers received reasonably fair treatment from managers and supervisors, but no firm conclusions can be drawn on the basis of the limited data available. In view of the above discussion, however, it may be significant that the few cases where discriminatory treatment was known or suspected to have occurred almost invariably involved Asian workers. Thus, to a certain extent, the differing skill levels of Asian and West Indian workers and their differing orientations towards the host soclety may be said to have cancelled each other out. In spite of their initially lower level of skill, the Asian workers' employment and occupational levels were remarkably similar to those of the West Indians, but they had achieved this at the expense of being more diligent, more amenable to discipline and, occasionally, more prepared to accept discriminatory treatnent.

A similar situation arises with respect to intergroup relations at the shop floor level. In the firms studied during the present research, there was a marked tendency for both West Indian and Asian workers to remain within their own social groups. However, it would appear that they did so for different reasons. In the social sphere, we again find that West Indian immigrants are more "skilled", In the sense that they speak English as their native language and are much more conversant with British 
norms and values. Moreover, the West Indians wish to achieve full social acceptance, whilst the Asian imigrants, in general, prefer to remain socially separate, mainly because this enables them to retain their own distinct way of life, but perhaps also as a means of avolding possible social conflict. As with work integration, however, the attitudes of members of the host society play a decisive role in determining the form of adjustment achieved by the immigrants. British workers, we suggested, are prepared to accept coloured immigrants as fellow workers, but are much less prepared to accept them in the realm of social relationships. On the other hand, despite the generally low level of social acceptance, there were indications that British workers were more prepared to accept coloured workers socially when their cultural background was similar to their own and when they were prepared to conform with the British workers' expectations towards coloured people by accepting a lower status role.

It w111 be seen that the respective orlentations of West Indian and British workers are largely incompatible. They colncide to the extent that the West Indians desire social acceptance and the British workers are more prepared to accept them because of the greater similarities in cultural background. This, it is suggested, explains the hisher degree of social integration achieved by West Indlan workers in certain of the firms studied during the present research. For the most part, however, this is counterbalanced by the fact that the British workers are, in general, not prepared to accept coloured 
immigrants socially, irrespective of their cultural background, and West Indians are not prepared to accept the lower status role expected of them. In the case of the Asian workers, on the other hand, both groups have similar expectations towards each other; neither desires social integration. Thus, whereas the Asian workers remained in their own social groups from choice, the West Indlans did so mainly because they were not accepted by the white workers or because they wished to avoid the possibility of rejection.

It might be expected, therefore, that relations between West Indian and British workers would involve greater social conflict than in the case of Asian workers. Several writers (e.g. Richmond (1954); Banton (1955); and Burt (1960)) have noted the existence of considerable resentment amongst West Indian immigrants concerning their lack of social acceptance. In the present research, few of the coloured respondents expressed any bitterness towards white workers with respect to this question, but those who did so were all West Indians. Similarly, in cases where white workers complained of difficulties in achieving an acceptable pattern of relationships with coloured workers, the workers concerned were usually West Indian. In other respects, however, greater resentment was expressed against Asian immigrants. Such resentment arose mainly because of differences in cultural background - the Asian workers' language difficulties, their different customs, and so on. Th1s suggests that the Asian 1mmigrants' desire to remain separate from the British workers was not entirely 
successful in avoiding social conflict. Although both groups wished to keep to themselves, this is possible only to a limited extent in a restricted environment such as that of the industrial concern, and the present research indicates that the presence of the Asian workers, in spite of their desire to remain separate, still impinged sufficiently upon the working life of British employees to give rise to resentment and friction.

Thus far we have been discussing industrial integration in the context of an immigration situation in which, as Burt puts 1t, "race is a complicating, but not defining factor." 1 In relation to the process of integration in the longer term, however, the present situation must be seen as no more than a period of transition. In the future, the characteristics of the migrant population and also the vacancies avallable in the receiving situation will become less and less important as factors determining the form of adjustment achieved by coloured workers in British industry. The children of the present generation of migrants, brought up and educated in this country, may retain some aspects of their parents' cultural background, especially in the case of Asian children, but the main difference between them and native British children will simply be a matter of colour. Similarly, as they will begin to look for jobs at the same time as British school leavers, the "objective" vacancies available in industry will be the same for both groups.

1. See page 125 . 
The main factor determining their level of industrial integration will, therefore, be the attitudes of British people in industry towards them.

Writing in 1960, Burt stated: "....we are not discussing a static situation. It is conceivable - though hopefully not probable - that a clear and identifiable "race problem" is evolving in Great Britain." He concluded, however, that the situation was "relatively stable and perhaps improving." As far as the industrial situation is concerned, the present writer would tend to take a rather more pessimistic view. As we have seen, the present generation of migrants have made considerable progress towards work integration, at least when judged in terms of their skills, cultural background and so on. Nevertheless, the range of jobs available to them is still restricted owing to the large number of firms still employing no coloured worikers, and their opportunities for advancement are IImited, partly by their lack of adequate apprenticeship training and partly by the reluctance of British workers, and also management, to accept them in higher status jobs. The danger for the future, and it is a very real one, lies in the possibility that the next generation of coloured workers will not maintain the progress made by their parents and may, in certain spheres, even have to begin again at the bottom of the industrial ladder.

As we noted in Chapter Four, one of the main factors limiting the number of jobs avallable to coloured workers is sheer inertia. Firms which have not been compelled by a 
shortage of white workers, serlously to consider the employment of coloured labour seem to prefer to "leave well alone" rather than to take a chance on the unknown. Similarly, there are indications that managers are reluctant to give apprenticeships to coloured school leavers because they fear that the white workers may not accept them in skilled jobs. We have seen that, once the inftial resistance to coloured workers has been overcome, most firms find that they are satisfactory workers, and that although resistance to coloured worke rs in higher status jobs does exist, this can be overcome, and, in fact, has been overcome in a number of firms. In the writer's view, however, there is a strong possibility that firms not already employing coloured workers will not begin to do so and that in the firms in which they are employed, coloured school leavers will not be given apprenticeshlp jobs, simply because, al though the risks involved may be relatively slight, the material benefits to the firm will be negligible. Providing sufficient white workers of an adequate standard can be obtained, firms will not lose anything by not employing coloured workers. Thus the only reasons for doing so are considerations such as the desire to avoid a possible future social problem or a belief in social equality, and it seems unlikely that this will be enough. Bven if the social consequences of not employing coloured workers are recognised, it is all too easy for individual firms to argue that their own special problems make it too difficult for them to do so in their particular case, and to leave the employment of coloured labour to other 
firms which are also taking a similar view.

In this case, the range of jobs available to the next generation of coloured workers is likely to be restricted largely to those available in firms which are already employing coloured immigrants at the present time. Moreover, as far as employment levels are concerned, coloured school leavers are likely to be in a worse position than their parents. Although the adult immigrant may have found it difficult to obtain a skilled or semi-skilled job at first, he at least had the opportunity of taking an unskilled job and perhaps later working his way up the job hierarchy. For the coloured school leaver at the age of fifteen, even this avenue for advancement is not available until he is old enough to be employed as a labourer. In the mean time, he may have to bide his time in a dead-end job, with the result that, when he does enter industry, he has no qualifications or training, and must accept the most menial of labouring work.

If future progress towards work integration is likely to be restricted, what then of social integration? We have seen that, in the realm of social relationships, the present generation of migrants has made relatively little progress towards industrial integration. However, the present research suggests that close social relationships are more likely to arise a) when the immigrants' cultural background is similar to that of the British workers; b) when there are few coloured workers in the firm or department concerned; and c) when social contact occurs within the content of a close, formal 
work relationship. In the future, cultural differences between white and coloured workers may be expected to decrease considerably. This is not to say that they will disappear completely. As we have already noted, Asian children are likely to retain certain aspects of their parents culture and similarly, in the case of West Indian children, some allegiance to and interest in the West Indies may remain. Nevertheless, the Aslan children w1ll at least learn English and gain much more knowledge of the British way of life than their parents, and as far as West Indian children are concerned, the minor differences in interests and topics of conversation which arise through being born and brought up in a different country from their British work-mates will largely disappear. One might expect, therefore, that they will become more integrated into the social structure of the firms in which they work than the present generation of migrants.

On the other hand, lack of work integration may to a considerable extent inhibit progress towards social integration at work. If firms continue to be reluctant to begin employing coloured workers, they will continue to be employed in relatively large numbers by those already doing so. Restriction of the range of jobs available to coloured workers within these firms will result in their concentration in particular departments and on particular jobs; and restriction of coloured workers to labouring jobs or the "differentiated" type of skilled and semi-skilled job will tend to prevent the development of social relations based on formal work relation- 
ships. All this will encourage the white workers to regard coloured workers as a separate group within the firm with their own group characteristics, instead of regarding each coloured worker as an individual. Thus coloured workers may still be thought of as strangers, even though cultural differences are in fact minimal. Furthermore, the restriction of coloured workers to lower status jobs may be expected to reinforce beliefs concerning the low social status of coloured people. On balance, therefore, there seems to be a strong possibility that the next generation of coloured workers will make little more progress towards social integration at work than their parents.

Thus, within the present immigration situation, there are the seeds of a future race problem in British industry; a situation in which coloured workers will become the "second class citizens" of the industrial world, confined to certain industries which the white workers prefer to avoid, confined to the least desirable jobs within these industries and socially segregated from the remainder of the labour force. Perhaps this is an over-pessimistic view of the situation, but it is a possibility which must be faced now whilst there is still time to avert 1t. The measures suggested in the recent White Paper on immigration ${ }^{1}$ seem unlikely to be sufficient to achieve this end. The prevention of discrimination in Employment Exchanges

1. Immigration from the Commonwealth London: H.M.S.O. Cmnd. 2739. August 1965. 
may be a necessary step, but it must be remembered that firms are no longer required by law to fill vacancies through an Employment Exchange, and as we have seen, many firms prefer to contact prospective coloured workers through existing workers rather than to use official channels. The White Paper states that the efforts of the Youth Employment Service to help Commonwealth immigrant school leavers to obtain employment and training "have met with a welcome measure of success." Against this, there is the evidence of the present research and the statement of a Youth Employment Officer (quoted on page 184) that she would like to refuse to send anyone else to employers who discriminated against coloured people, but they were "so numerous that this would be impossible to carry out." 1

If these measures are unlikely to be successful, or at least are unlikely to be successful enough, what further measures then are called por? The main necessity, the writer would suggest, is the extension of the forthcoming Race Relations Act ${ }^{2}$ to include legislation against discrimination in employment in addition to discrimination in public places. One argument

1. Two recent newspaper reports also suggest that coloured youths are experiencing considerable difficulty in obtaining apprenticeships and white collar jobs. The first ("'Insurance firms have race bar'", The Observer, 28th November, 1965) states: "The C.A.R.D. (Campaign Against Racial Discrimination) action group hopes to send carefully matched pairs of applicants - one coloured, one white - to be interviewed for jobs. A preliminary test with several firms showed they were prepared to reject a West Indian youth of good appearance and university entrance standard in favour of a less qualified English youth." The second ("Inmigrant group alleges promotion barrier", The Guardian, 1 st December, 1965) states that, according to the Indian Workers Association of Great Britain, "Immigrant children leaving school are finding it almost impossible to obtain apprenticeships or to join training schemes."

2. Race Relations Act 1965 London: H.M.S.O. 
against such a law is that infringements of 1t would be difficult to prove and it would therefore be difficult to enforce. This may be so, but the success of the Fair Employment Practices commissions operating in several American states, particularly New York, demonstrates that enforcement of such legislation is certainly not impossible. ${ }^{1}$ Furthermore, enforcement through legal channels is not the only way in which legislation against discrimination in employment can be effective. Most American Fair Employment Practices laws provide for a "conciliation stage" after sufficient evidence has been obtained to support an allegation of discrimination. Norgren and Hill (1964) state: "In FFP law parlance, the term "conciliation" denotes conference approaches and techniques that utilize a combination of persuasion and coercion. The commissioner meets with the non-

1. After examining the experience of established Pair Employment Practices commissions in the United States, Norgren and Hill (1964) conclude: "The analysis of the effects of FHP commissions and their work presented in this chapter has adduced strong evidence that FEP legislation of the type now in effect in more than a third of the states can, if effectively administered, be a potent instrument for combating discrimination in employment. Follow-up reviews of compliance actions conducted by the longestablished commissions in New York, New Jersey, Philadelphia, and other jurisdictions provided the most direct indications of progress in overcoming raclal bias in the allocation of jobs. The reviews and other studies conducted by the New York State Commission, in particular, revealed major breakthroughs and subsequent sustained improvement in employment of Negroes in banking, insurance, retall trade, and public utilities and in numerous traditionally "all white" occupations in other industries. These evidences of substantial positive results from commission compliance efforts are borne out by the Census statistics on employment by occupation and color for 1950 and 1960. A 1950-60 comparison of nonwhite representation in fourteen middle- and upper-level occupational categories in New York State revealed striking increases in nine categorles end significant improvements in the other five. Moreover, on the average the gains in nonwhite representation in New York wero more than double, and in several instances more than triple, the corresponding increases in the total for three Midwestern states that had non-enforceable laws during 1950-60." 
complying employer and endeavours to persuade him to correct his practices voluntarily, while as an ald to the persuasion process, keeping him reminded that his non-compliance is illegal and may, if persisted in, result in unfavourable publicity or even legal sanctions." According to Norgren and Hill, "The great majority of complaint cases handled by the New York Commission have been satisfactorily concluded through conciliation, both with respect to adjustment of individual grievances and revision of general policles and practices." 1 In Britain, the necessary machinery for the operation of legislation against discrimination in employment has already been devised in relation to the question of discrimination in public places. The Race Relations Act 1965 provides for a Race Relations Board and local conciliation committees in such areas as the Board considers necessary. It will be the duty of the local conciliation committees to receive and consider any complaint concerning discrimination in places of public resort; to make such enquiries as they think necessary with respect to the facts alleged in any such complaint; and, where appropriate, to use their best endeavours by communication with the parties concerned or otherwise to secure the settlement of

1. It may even be that, in some cases, compliance with ant1discrimination laws could be obtained without the necessity of going through any official channels whatsoever. Already coloured immigrant organisations are testing the probable effectiveness of the approaching legislation against discrimination in public places by patronising public houses where landlords are said to practice a total colour bar or segregation (see "Smethwick opens up to the 'freedon drinkers'", The Guardian, 15th November, 1965, page 5). It seems likely that many landlords will cease to discriminate of their own accord simply because they wish to avoid the possible inconvenience and adverse publicity of an official enquiry. 
any difference between them and a satisfactory assurance against further discrimination. In any case where the local conclliation committee is unable to secure such a settlement, or such a settlement and assurance, or it appears that such an assurance is not being complied with, the committee will make a report to the Race Relations Board, who will, if it appears that an offence has taken place and is likely to continue, report the matter to the Attorney General or the Lord Advocate, as the case may be. In essence, these procedures are remarkably similar to those employed by American Fair Employment Practices commissions, and there would seem to be little difficulty involved in the extension of the provisions of the Race Relations Act to cover legislation against discrimination in employment. However, American experience indicates that these provisions alone are unlikely to be sufficiently effective. Norgren and Hill suggest that, in addition to examining specific complaints of discrimination, FEP commissions should attempt to eliminate all-over patterns of discriminatory practices pervading entire firms and should plan and programme these efforts over a number of years; should deal with complaints of discriminatory practices filed by minority-group organisations as well as by aggrieved individuals; and should initiate their own investigations when information suggesting the existence of discriminatory practices comes to their knowledge and, if the evidence warrants it, attempt to correct the discriminatory situation. The extension of the powers of local conciliation committees to include these procedures would, in the writer's 
view, greatly increase their effectiveness in the field of employment. It would transform their role from that of merely responding to specific allegations of discrimination to that of an organisation working in a much more positive manner to secure the industrial integration of coloured people in Great Britain.

If, as we have suggested, one of the main factors limiting the range of jobs available to coloured workers is simple inertia rather than any deep-rooted opposition to their employment, then there is little doubt that, by means of the powers and procedures outline above, local conclliation committees could make a very significant contribution towards overcoming discriminatory practices in industry, often without the necessity of resorting to legal sanctions. On the other hand, nere exhortation of employers to discontinue such practices, in the absence of any effective legislation to enforce compliance, is unlikely to produce the desired change in employment policies. Norgren and Hill state that, in the United States, "Neither non-enforceable FEP $^{1}$ laws nor voluntary FEP programs have had any appreciable effect in reducing employment discrimination." Moreover, the existence of laws against discrimination in employment provides a powerful weapon for employers who wish to initiate non-discriminatory employment practices, but who meet with resistance from the white workers. According to Norgren and Hill, "Several company representatives stated that

1. That is, laws which prohibit discrimination, but do not provide for effective machinery for their enforcement. 
objections from white employees to the use of Negroes in nontraditional jobs could be effectively countered by citing state FEP laws as a reason for changes in company policy." It must be admitted, of course, that it is often dangerous to extrapolate directly from American experience in race relations to the British situation, but in the case of the examples cited above, the writer is strongly of the opinion that British reaction to legislation against discrimination in employment would not differ markedly from that already encountered in the United States.

This is not to say that the writer believes that effective legislation can provide a panacea which will immediately eliminate discrimination in employment or that such legislation alone can ensure the full industrial integration of coloured workers even in the longer term. For this to occur, far reaching changes in the attitudes and behaviour of both employers and Britlsh workers are also necessary. For these changes to take place, however, dispersal of coloured workers throughout industry and throughout the different status levels within industry would seem to be a necessary prerequisite, and this does not seem likely to occur without the type of legislation outlined above. Furthermore, the time for such legislation is now, whilst the coloured school leavers are beginning to enter the labour market. We are at a cross-roads. If these children continue the progress made by their parents then there is the possibility that full industrial integration may be achieved in the foreseeable future. If they do not, 
then the present inequalities of employment and occupational levels will be perpetuated, perhaps becoming entrenched in the industrial system and thus more resistant to effective action in the future. The introduction of legislation against discrimination in employment may cause inconvenience or even hardship amongst employers who are unjustly accused of discriminatory practices; it may cause friction, either between workers and management or between white and coloured workers, where white employees are reluctant to accept coloured workers in skilled jobs or in apprenticeships, but this is a small price to pay for the avoldance of a future social problem of very serious magnitude. 


\section{APPENDIX I}

\section{FIRMS VISITED DURING THE INTERVIEW SURVEYS}

\section{Non - Directive Survey}

1. Precision Engineers Ltd.

2. Bradfield Foundry.
Out of a total of 3,633 male manual workers, 381 were West Ind 1 an and 118 Indians and Pakistanis. The coloured workers were mainly employed in unskilled and semi-skilled jobs on the production side.

Respondents: Personnel Director, Personnel officer, Training officer, Union official and Works Council representative.

The male manual workers consisted of 77 Indians and Pakistanis, 37 British workers, 12 Italians, 4 West Indians and 4 Arabs. 19 British and 4 West Indian women were also employed. Coloured workers were employed in skilled, semi- and unskilled jobs. Respondents: Works Superintendent, Technical Controller, Production Manager, Fettling Shop Foreman. 
3. C1ty Transport.

4. Regal Manufacturing Co.

5. Ensign Spring Co.

6. Brlerley Metal Works.
Out of 4,088 employees, 334 were coloured, including 238 West Indians, 83 Pakistanis, 10 Indians, one West African, one Somali, and one Arab. The coloured workers were mainly conductors, but there were 24 drivers, most of whom had been recruited from amongst the conductors. Respondents: Personnel Manager, Assistant Personnel Manager.

40 coloured workers were employed out of a total of 1,650 employees. All the coloured workers were West Indian apart from two "East Indian youths."

Respondent: Personnel Manager.

A light manufacturing company employing 20 to 25 West Indians out of a total 800 to 900 employees. All the coloured workers were in unskilled jobs. Respondent: Personnel Manager.

A foundry where 700 coloured workers were employed out of a total of 2,300 employees. The majority were Indians, but there were also some Pakistanis, about 6 West Indlans and one or two Arabs and West Africans. Coloured workers were employed in skilled, semi-skilled and unskilled jobs. Respondent: Labour Officer. 
7. Westwood Foundry.

Out of approximately 500

employees, $45 \%$ were Indian, 40\% British, $8 \%$ Pakistani and $3 \%$ West Ind1an. Coloured workers were employed in skilled, semi-skilled and unskilled jobs.

Respondents: Labour Officer, Assistant Labour Officer.

8. Components Ltd. A foundry employing approximately 500 workers; $4 \%$ were Indians, $4 \%$ were Pakistanis and $4 \%$ were West Indians. Some coloured workers had obtained skilled jobs, but the majority were labourers. Respondent: Personnel officer.

9. Drop Forgings Ltd.

10. Trafford Iron and Steel Co.

West Indlans were the only coloured workers employed and they constituted $10 \%$ to $12.5 \%$ of the labour force. They did semi-skilled and labouring jobs. Respondent: Personnel officer. 
11. Central Glass Works.

12. Muirhead Foundry.

13. Edge Tools Itd.

14. Omega Metals Ita.
All the coloured workers were West Indian. They constituted some $12 \%$ of the labour force and were mainly employed in unskilled jobs on the production side. Respondent: Personnel Manager.

$75 \%$ of the labour force was coloured, the majority being Indians, but there were also a few Pakistanis and West Indians. Coloured workers were employed "on every operation in the foundry except fitting." Respondent: Personnel Manager.

The firm employed 81 coloured workers, including 70 Pakistanis, Ind Ians and Arabs, 9 or 10 West Indians and one or two Africans, out of a total labour force of 218. The coloured workers were in labouring and semi-skilled jobs.

Respondents: Labour Manager; 2 Chargehands, 6 British workers, 6 West Indians, 5 Pakistanis and one Indian (formal interviews).

A small heavy engineering company. The manual workers consisted of 53 Pakistanis, 9 British workers and one West Indian. The coloured workers were employed on skilled, semi-skilled and labouring jobs. One of the 
Pakistanis was a Chargehand.

Respondents: Works Manager;

Foreman, Works Engineers, 11 Pakistanis (including the Chargehand),

6 British workers and one West

Indian. (formal interviews)

\section{Directive Interview Survey}

15. Major Castings Ltd.

A foundry employing 44 coloured workers, including 29 West Indians, 12 Pakistanis, 2 West Africans and one Indian, out of a total labour force of 3,200 . In the main the coloured workers were labourers, but a small proportion had obtained semiskilled jobs.

Respondents: Personnel Manager, Assistant Personnel Manager; Convener of the Shop Stewards Committee, one Pakistani worker (formal interviews); one British worker and one West African (1nformal interviews).

16. Quality Steel Co.

A steel works employing about 6 Arabs and Pakistanis out of a total labour force of 700 . The coloured workers were mainly employed in labouring jobs. Respondents: Personnel officer; British worker (formal interview). 
17. Tool Steel Ltd.

18. Annerley Iron Foundry.

19. Leigham Cannery.
A heavy engineering company, employing 40 to 50 coloured worliers, mainly Pakistanis and Arabs out of a total labour force of 1,200. Colourea workers were mainly employed in unskilled jobs. Respondents: Personnel Manager, Assistant Personnel Manager.

Ironfounders and engineers. 9 coloured workers were employed (6 Arabs, 2 West Indians and one Pakistani) out of a total of 50 employees. All were in unskilled jobs, except for one Arab semiskilled worker.

Respondents: Works Manager; one West Indian, one Arab and one British worker (formal interviews).

A food canning and packing factory. About 1,000 workers were employed, $10 \%$ of whom were coloured. These were mainly Pakistanis and West Indians, in about equal numbers, but there were also "a few Indians and one or two Somalis." The coloured workers were in labouring and semi-skilled jobs.

Respondents: Personnel officer; 3 British workers, 2 West Indians, one Somali (formal interviews). 
20. Hamilton Engineering Co.

21. Torrington Cutlers Ltd.

22. Grange Graphite Co.
14 coloured workers were employed out of a total of 2,400 manual workers. All were West Indian, but Pakistanis had been employed in the past. Coloured workers were employed in unskilled and semi-skilled jobs in about equal numbers.

Respondents: Labour officer;

6 West Indians, one British worker (formal interviews); 2 West Indians (informal interviews).

Goldsmiths, silversmiths and cutlers. 5 coloured workers were employed, all West Indians, out of a total of 300 workers. All were in unskilled jobs, mainly services to production. Respondents: Works Director; 2 British workers, 5 West Indians (formal interviews).

75 coloured workers were employed out of a total of 632 employees. About $60 \%$ of the coloured workers were Pakistanis and Arabs, the remainder being West Indians. Almost all were in unskilled jobs. Respondent: Personnel officer.

A steel works and engineering company, this firm employed 200 coloured workers out of a total labour force of 2,600 . 
24. Sterling Metal Co.

The majority were Arabs and Pakistanis, but "quite a few" were West Indians and there were also Somalis, East Africans and South Africans in smaller numbers. They were mainly in unskilled jobs, but some had obtained semi-skilled posts. Respondents: Personnel Manager, Labour Manager, Assistant Labour Manager; a foreman, 6 British workers, 3 Arabs, 2 Somalis, one Pakistani, one West Indian and one East African (informal interviews).

Stainless steel manufacturers. 89 coloured workers (Bomalis, Arabs and Pakistanis) were employed, mainly in semi-skilled and unskilled jobs, but a small number had obtained skilled jobs and one was a Chargehand. Respondents: Personnel Manager; 2 Departmental Managers, a foreman, a Shop Steward, one British worker and 4 Somalis (informal interviews).

25. Ridgeway Steel Co.

Manufacturers of steel strip, steel bars and wire. 14 Pakistanis were employed out or a total of 2,500 employees. 10 were labourers and the remainder were in semi-skilled jobs. Respondents: Personnel Manager, 
Assistant Personnel Manager;

Department Manager, a foreman and 2 Pakistanis (informal interviews).

26. Stainless Steel Itd.

A stainless steel foundry, this firm employed 3 coloured workers, 2 Pakistanis and an Arab, out of a total of 109 manual workers. All were in unskilled jobs. Respondents: General Manager; one British worker and one Pakistani (informal interviews).

27. Polton Rolling Mills.

80 to 100 coloured workers, mainly Arabs and Pakistanis, were employed out of a total of 550 to 600 employees. The majority were labourers, but some had obtained semi-sikilled jobs. Respondents: Labour Officer; one British supervisor and one Pakistani (formal interviews); 2 Departmental Managers (informal interviews).

28. Castle Iron Co.

An iron and steel works employing 20 coloured workers, mainly Pakistanis, out of a total of 190 to 200 employees. The coloured workers were in unskilled and semi-skilled jobs. Respondent: Personnel Manager. 
29. Steel Bars Itd.

30. Blackford Rolling Mills.
A rolling mill, employing 8 coloured workers, all Arabs, out of a total of 62 employees. The coloured workers were employed in semi-skilled and unskilled jobs.

Respondents: Works Director; a Poreman, one British worker and one Arab (formal interviews).

This firm had previously employed Arab and Pakistani workers on a full time basis, but at the time of the present study they were employed only as casual labourers during the yearly "shut down". Respondent: Production Services Manager.

31. Pentland Alloys Ltd. A heavy engineering company. 35 West Indians were employed out of a total of 4,000 employees. They were in sem1-skilled and unskilled jobs. Respondents: Personnel Manager; 4 British workers, 4 West Indians (formal interviews). 


\section{APPENDIX II}

\section{INTERVIEW SCHEDULES: PILOT SURVEY}

\section{A. British Workers}

1. How do you feel about working at a firm which employs coloured labour? Other things being equal, would you rather work where only white people were employed? Could you give reasons for your answer?

2. If you had the choice of who you were going to work with, which of the nationalities, in order, on the following list would you prefer: African, Arab, British, Irish, Indian, Pakistani, West Indian? Could you give reasons for your choice?

3. Would you object to a coloured worker being appointed to a position equal to yours?

4. Would you object to a coloured worker being appointed to a position above yours?

5. I have heard conflicting reports about coloured workers, some people say they are good workers, others say bad. What do you think?
a) Are they slow or fast to learn?
b) Do they work hard or not once they have been trained?
c) Do they show inititative or just do as they are told?
d) Do they stand more pushing about by management, or do they tend to be difficult to deal with?
e) Are they more or less intelligent than white workers, or about the same?


f) Do they require more or less supervision?

g) (If not stipulated in answers to above questions) Do your answers apply to all coloured workers, or just some races of coloured workers? If so, which?

6. Do they receive the same treatment as white workers?

7. Do they expect the same treatment as white workers?

8. Do the coloured workers mix freely with other races, either white or other coloured, or do they keep themselves to themselves?

9. Do you think that coloured workers constitute a danger to

a) the health of other employees,

b) the safety of other employees,

c) the morale of other employees.

10. In the event of a trade recession, do you think that:

a) All things being equal, white workers should have preference,

b) Regardless of ability, length of service, etc. they should still have preference.

11. Is there anything in particular about coloured workers that you object to?

12. What do you think of the Inmigration Act?

\section{B. Coloured Workers}

1. Cail you speak English? (Not asked in the case or West Indian respondents).

2. Where did you come from originally? 
3. What did you do there?

4. Why did you come to England?

5. When did you arrive in England?

6. Was it difficult to find work?

a) How long did it take you to get a job?

b) What was your first job?

c) How did you get the job - through the Employment Exchange, a friend, by going to firms yourself?

7. What other jobs have you had since you came to England?

8. Why did you leave them?

9. What do you do here?
a) How did you learn it?
b) Was it difficult to learn?
c) How long did it take to learn it?
d) Did other people help you to learn it?

10. Do you like your present job? If not, what is it that you do not like?
a) Do you want to do it always?
b) If not, what job would you really like to do?

11. How have English people treated you at work since you arrived here?
a) Have they been fair in the way that they have acted towards you?
b) Have they treated you as an equal?
c) Have they been friendly?
d) Are Fnglish people more or less friendly outside the works?


12. If you could choose who you were going to work with, who would you prefer to work with on the following list? African, Arab, English, Indian, Pakistani, West Indian? Could you give reasons for your cholce?

13. Do you intend to remain in England or return home eventually?

\section{Supervisors}

1. How do you feel about working at a firm which employs coloured labour? Other things being equal would you rather work where only white people were employed?

Could you give reasons for your answer?

2. If you had the choice, what nationalities in the following list would you rather have work under you: African, Arab, British, Irish, Indian, Pakistani, West Indian?

Could you give reasons for your choice?

3. Would you object to a coloured worker being appointed to a position equal to yours?

4. Would you object to a coloured worker being appointed to a position above yours?

5. I have heard conflicting reports about coloured workers, some people say they are good workers, others say bad. What do you think?

a) Are they slow or fast to learn?

b) Do they work hard or not once they have been trained?

c) Do they show initiative or just do as they are told?

d) Do they stand more pushing about by management, or do they tend to be difficult to deal with? Is it easier or more difficult to give orders to coloured workers? 

e) Are they more or less intelligent than white workers, or about the same?
f) Do they require more or less supervision?
g) (If not stipulated in answers to above questions) Do your answers apply to all coloured workers, or just some races of coloured workers? If so which?

6. Do they receive the same treatment as white workers?

7. Do they expect the same treatment as white workers?

8. Do the coloured workers mix freely with other races, elther white or other coloured, or do they keep themselves to themselves?

9. Do you find that, where no financial change is involved, coloured workers resent being transferred to different jobs more or less than white workers?

10. Do you think that coloured workers constitute a danger to:
a) The health of other employees.
b) The safety of other employees.
c) The morale of other employees.

11. In the event of a trade recession, do you think that:
b) Regardless of ability, length of service, etc., they should still have preference?

12. Is there anything in particular about coloured workers you object to?

13. What do you think of the Immigration Act? 
APPENDIX III

INTERVIEW SCHEDULE : DIRECTIVE INTERVIEW SURVEY

A. Management

\section{Background}

1. When did you first start employing coloured workers?

2. What made you decide to employ them?

3. Did you have any initial difficulties when they were first employed?

4. What is the present racial constitution of the firm?

5. What jobs do the coloured workers do?

6. What jobs do the white workers do?

7. Do you have any preference with regard to the different races of coloured workers?

II. Initial Skill Level of Immigrants

1. Do you think that immigrant workers, when they first arrive in this country are, in general, more skilled than British workers, less skilled, or about the same?

2. Are there any differences in the skill level of the different races of immigrant workers?

III. Training Coloured Workers

1. Do you find coloured workers slow or fast to learn?

2. Can they be trained on skilled jobs, or semi-skilled jobs, or can they only do labouring work?

3. Are there any differences between the different coloured races in these respects? 
4. What problems do you come up against in the training of coloured workers?

5. Do you use any special methods in the training of coloured workers?

IV. Assessment of Coloured Workers

I have heard conflicting reports about coloured workers. Some people say they are good workers, others say they are bad. What do you think?

1. Do they work hard, once they have been trained?

2. Are they capable of working at high speeds, say on piece work?

3. Do they show initiative or do they just do as they are told?

4. Do they show ambition or are they just satisfied with any job they can get?

5. Do the supervisors find them easier or more difficult to deal with than white workers?

6. Do they require more or less supervision?

7. Do you think that they are more intelligent or less intelligent than white workers, or about the same?

8. I have heard that some coloured workers are a bit accident prone and can be a danger to other workers. Have you found this to be the case?

9. Do your answers apply equally to all coloured races or only some?

v. Flexibility of Coloured Workers

1. Do you find that, where no financial change is involved, coloured workers resent being transferred from one job to another more or less than white workers?

2. Are coloured workers capable of learning more than one job? 
VI. Race Relations

1. Where do white and coloured workers come into contact with each other most when working?

2. How do they get on with each other when working?

3. Apart from contact necessitated by work, do the different races $\mathrm{mix}$ freely or do they tend to keep themselves to themselves?

4. Do the white workers like the coloured workers, dislike them, or do they tend to be indifferent?

5. How do the coloured workers feel about (a) the white workers, and (b) other coloured races, if employed?

6. Do the different races have much to do with each other outside the works environment, either socially or in works organised social activities?

VII. Labour Turnover

1. Do you think that labour turnover amongst coloured workers is higher or lower than it is with white workers, or about the same?

2. Why do you think that this is the case?

VIII. Hyglene

1. One of the major causes of friction where coloured workers have been employed has been the toilet question. Have you had any difficulties here?

2. What steps have you taken to overcome this problem?

\section{B. Supervisors}

1. What is your job?

2. How long have you worked here?

3. Did you begin work here before or after coloured workers were employed by the firm? 
4. (If before) Were there initial difficulties when coloured workers were first employed?

5. How do you feel about working for a firm which employs coloured labour?

6. Other things being equal, would you rather work for a firm which only employed white people?

7. Is there anything about coloured workers which you object to?

8. Do you have any preferences as regards the coloured races; would you rather have one coloured race than another working under you?

II. Initial Skill Level of Coloured Workers

1. In general, do you think that immigrant workers, when they first arrive in the country, are more skilled than British workers, less skilled than British workers, or about the same?

2. Does your answer apply equally to all coloured races, or are some more skilled than others?

III. Training of Coloured Workers

1. Do you think that coloured workers are slow or fast to learn?

2. Do you think that they can be trained on skilled jobs, semi-skilled jobs or neither?

3. What problems do you come up against in training coloured workers?

4. Do you use any special training methods for coloured workers?

5. What jobs do they in fact do?

6. Are there any differences between the coloured workers as far as training is concerned? 
IV. Assessment of Coloured Workers

I have heard conflicting reports about coloured workers, some people say that they are good workers, others bad. What do you think?

1. Do they work hard once they have been trained?

2. Are they capable of working at high speed, say on piece work?

3. Do they show initiative or just do as they are told?

4. Do they show ambition or are they satisfied with any job they can get?

5. Do you find it easier or more difficult to supervise coloured workers? (If so, why?)

6. Do they require more or less supervision than white workers?

7. Are they more intelligent than white workers, less intelligent or about the same?

8. I have heard that some coloured workers tend to be a bit accident prone, and can be a danger to other workers. Have you found this to be the case?

9. Do your answers apply equally to all coloured races or only to some?

v. Treatment of Coloured Workers

1. Do they receive the same treatment as white workers?

2. Do they expect the same treatment as white workers?

VI. Flexibility of Coloured Workers

1. Do you find that where no financial change is involved, coloured workers resent being transferred from one job to another more or less than white workers?

2. Are coloured workers capable of learning more than one job? 
VII. Race Relations

1. Where do white and coloured workers come into contact with each other most when working?

2. How do they get on with each other when working?

3. Apart from contact necessitated by work, do the different races $\mathrm{mix}$ freely or do they tend to keep themselves to themselves?

4. Do the white workers like the coloured workers, dislike them, or do they tend to be indifferent?

5. How do the coloured workers feel about (a) the white workers, and (b) other coloured races, if employed?

6. Do the different races have much to do with each other outside the works environment, either socially or in works organised social activities?

\section{Labour Turnover}

1. Do you think that labour turnover amongst coloured workers is higher or lower than it is with white workers, or about the same?

2. Why do you think that this is the case?

IX. Hyglene

1. One of the major causes of friction where coloured workers have been employed has been the toilet question. Have you had any difficulties here?

2. What steps have been taken to overcome this problem?

\section{British Workers}

1. What is your job?

2. How long have you worked here?

3. Did you begin work here before or after coloured workers were first employed by the firm? 
4. (If yes to 3) Were there any initial difficulties involved in the employment of coloured workers?

5. About how many coloured workers does the firm employ now?

6. How do you feel about working for a firm which employs coloured workers?

7. Other things being equal would you rather work for a firm which only employed white people?

8. Do you have any preference w1th regard to the coloured races, that 1s, would you rather have a man of one coloured race than another as a work-mate?

II. Initial Skill Level of Coloured Workers

1. In general, do you think that immigrant workers, when they first arrive in this country, are more skilled than British workers, less skilled, or about the same?

2. Do your answers apply equally to all coloured races, or are some more skilled than others?

III. Training of Coloured Workers

1. Do you think that coloured workers are fast or slow to learn?

2. Do you think that they can be trained on skilled jobs, semi-skilled jobs or can they only do labouring work?

3. Are there any differences between the different coloured races in these respects?

IV. Assessment of Coloured Workers

I have heard conflicting reports about coloured workers, some people say they are good workers, others bad. What do you think?

1. Do they work hard once they have been trained?

2. Are they capable of working at high speeds, say on piece work? 
3. Do they show initiative or do they just do as they are told?

4. Do they show ambition or are they just satisfied with any job they can get?

5. Do they stand more pushing around by management, or do they tend to be difficult to deal with?

6. Do they require more or less supervision than white workers, or about the same?

7. Are they more or less intelligent than white workers, or about the same?

8. I have heard that some coloured workers are a bit accident prone and can be a danger to other workers. Have you found this to be the case?

9. Do your answers apply equally to all coloured races or only to some?

v. Flexibility of Coloured Workers

1. Do you think that, where no financial change is involved, coloured workers resent being transferred from one job to another more or less than white workers?

2. Do you think that coloured workers are capable of learning more than one job?

VI. Race Relations

1. Where do you come into contact with coloured workers at work?

2. How do you get on with them?

3. Apart from contact necessitated by work, do the coloured workers mix freely with other races, either white or other coloured, or do they keep themselves to themselves?

4. (If the latter) Why do you think this is?

5. Do you personally have much to do with coloured workers, apart from contact necessitated by work? 
6. How do you think the white employees in general feel about the coloured workers?

7. How do you feel about them - do you like them, dislike them or are you indifferent?

8. Is there anything about coloured workers you object to?

9. Do you have anything to do with coloured people outside the works?

10. How do the different coloured races get on with each other at work?

11. In the event of a trade recession, do you think that:

(a) all things being equal, white workers should have preference?

(b) regardless of ability, length of service, etc., they should still have preference?

VII. Level of Work and Social Acceptance

1. Are you prepared to accept a West Indian as a) a labourer in your firm; b) a semi-skilled worker; c) a skilled worker; d) a supervisor; e) a personal friend at work; f) a personal friend outside work?

2. Are you prepared to accept a Pakistani as a) a labourer in your firm, etc. as above?

3. Are you prepared to accept an Indian as a) a labourer in your firm, etc, as above?

4. Are you prepared to accept an Arab as a) a labourer in your firm, etc. as above?

5. Are you prepared to accept an African as a) a labourer in your firm, etc. as above?

VIII. Treatment of Coloured Workers

1. Do coloured workers recelve the same treatment as white workers? 
2. Do they themselves expect the same treatment as white workers?

IX. Hygiene

One of the major causes of friction where coloured workers have been employed has been the toilet question. Have you had any difficulties here?

X. What do you think of the Immigration Act?

\section{Coloured Workers}

1. Where did you come from originally?

2. What did you do there?

3. Why did you come to Britain?

4. When did you arrive in Britain?

5. (a) Was 1t difficult to find work?

(b) How long did it take you to find a job?

(c) What was it?

(d) How did you obtain the job?

(e) Did you think that it would be more difficult to find a job now than when you first arrived in the country?

6. What other jobs have you had since you arrived in Britain?

7. Why did you leave them?

8. (a) What is your job here?

(b) Do you work on your own or with other people?

(c) Who do you work with (i.e. what nationality)?

(d) How do you get on with the people you work with?

9. (a) How did you learn your job?

(b) Did other people help you to learn it?

(c) Was it difficult to learn?

(d) About how long did it take? 
10. (a) Do you like the job?

(b) Is there anything about it you dislike?

(c) Do you want to continue with this job or would you prefer a different job if you could get one?

(d) Do you think you could do a better job, if given the opportunity?

(e) What job would you really like to do if you had the choice?

11. (a) How do you get on with the British workers?

(b) Have they been friendly or have they kept to themselves?

(c) Do they seem to like you?

(d) Do you like them?

(e) Do you have much to do with British people outside the works?

(f) Are British people more or less friendly outside the works or about the same?

(g) How do you get on with the other coloured races employed by the firm?

(h) Do you have any preferences with regard to the nationality of people you would like to work with?

12. Do you intend to stay in Britain or return home eventually?

13. Do you like working in Britain?

14. Is there anything you have disliked about it - anything you think should be changed?

15. Was Britain different from what you expected it to be, or about the same? 


\section{APPENDIX IV}

POSTAL QUESTIONNAIRE SCHEDULE

\section{A. THE EMPLOYMENT POSITION OF COLOURED IMMIGRANTS}

1. When did you first employ coloured workers?

2. What made you decide to employ them? (Please tick where relevant)

a) Lack of alternative sources of labour........

b) Humanitarian reasons......

c) As a matter of course, when they became available.....

d) Any other reasons (details would be appreciated)......

3. What numbers of the following nationalities do you employ and in what class of job?

\begin{tabular}{|l|l|l|l|l|}
\hline & Number employed & Skilled & Semi-skilled & Labouring \\
\hline British & & & & \\
\hline West Indian & & & & \\
\hline Pakistani & & & & \\
\hline Indian & & & & \\
\hline Arab & & & & \\
\hline African & & & & \\
\hline Any others & & & & \\
\hline
\end{tabular}

4. What type of jobs do the coloured workers do within these categories?

West Indian

Pakistani 
Indian

Arab

African

5. Has any of the coloured nationalities proved to be more satisfactory as employees?

If this has been the case, could you give some details of this group's advantages over the others?

B. THE STANDARD OF COLOURED EMPLOYEES

1. How do you find the level of skill of the following national groups compared with that of the British worker? Are they more skilled, less skilled, or about the same?

West Indian

Pakistan 1

Indian

Arab

African

2. Do you think that, given the opportunity, they are capable of doing skilled jobs, semi-skilled jobs, or can they only do labouring work?

West Indian

Pakistani

Indian

Arab

African

3. Have you had any training aifficulties with any of the following national groups?

Details of any difficulties you have had would be appreciated.

West Indian

Pakistani

Indian

Arab

African

4. Do you find members of the following national groups, once they have been trained, more hard working than British workers, less hard working, or about the same?

West Indian

Pakistani 
Indian

Arab

African

5. Do you find workers of the following national groups are more or less amenable to discipline than British workers, or about the same?

West Indian

Pakistani

Ind 1 an

Arab

African

6. Apart from the question of amenability to discipline, do you find that they require more or less supervision than British workers, or about the same amount? Comments on any supervisory difficulties you have had would be appreciated.

West Indian

Pakistani

Indian

Arab

African

7. Do you find workers of the following national groups more or less flexible ( $1 . e .$, capable of being put on different types of job) than the British workers, or about the same?

West Indian

Pakistani

Ind 1 an

Arab

African

8. Is labour turnover amongst the various immigrant groups higher or lower than it is with British workers, or about the same?

9. How do the various coloured groups compare with white immigrants, such as the Irish, with regard to such attributes as skill, willingness to work, amenability to discipline, labour turnover, etc.? 
C. SOCIAL RELATIONS

1. How do the white workers feel about working in a firm which has coloured employees?

a) Was there any initial resistance to their employment?......

b) Are they willing to accept coloured workers as workmates?.....

c) Do they accept coloured workers in social situations, e.g., during tea-breaks, in the canteen, on the works social activities, or do they tend to keep themselves apart?........

d) Are they any more willing to accept one coloured nationality than another:

(1) as work-mates .........

(11) socially $\ldots \ldots \ldots$.

e) One of the major complaints of white workers has often been about the coloured workers'use of toilets. Have you had any difficulty over this question?...........

f) What other complaints (if any) do the white workers have concerning coloured employees?........

2. Do the different coloured nationalities show a willingness to mix socially with the white workers, or do they seem to prefer to keep to themselves?

West Indian

Pakistani

Indian

Arab

African

3. How do the different coloured nationalities (1f more than one is employed) get on together?

a) Do they readily accept each other as work-mates?.....

b) Do they mix socially (e.g., during tea-breaks, in the canteen, etc.) or do they tend to stick to their own national groups?..........

4. What have you found to be the best policy with regard to the employment of the different coloured nationalities?

a) To employ only one nationality ........

b) To keep the different nationalities separate (e.g., on different shifts or in different departments).....

c) To employ and place them irrespective of nationality.... 
D. ANY OTHER COMMENTS

Comments on any points which you feel have not been adequately covered by the questionnalre would be appreciated. 
REFERENCES

Alavi, H.A. (1963) "Pakistanis in Britain". London Counc1l of Social Service: Extract from a report prepared for the Overseas Socialist Fellowship.

Allport, G.W. (1951) "Prefudice: A Problem in Psychological and Soclological Causation", in Towards a General Theory of Action. T. Parsons and E. Shils (eds.) Harvard University Press.

Allport, G.W. (1958) The Nature of Prejudice. New York: Doubleday.

Allport, G.W. (1962) "Prejudice: Is it Societal or Personal?" J. Soc. Issues, Vol. 18.

Argyle, M. (1964) Psychology and Social Problems. London: Methuen.

Banton, M.P. (1955) Coloured Quarter. London: Jonathan Cape. Banton, M.P. (1959) Wh1te and Coloured. London: Jonathan Cape. Banton, M.P. (1960) "Social Distance: A New Appreciation". The Sociological Review, Vol. 8 .

Benedict, Ruth (1943) Race and Racism. London: Scientific Book Club.

Bernard, Jessie (1950) "Where is the Modern Soclology of Conflict". Amer. J. Sociol., Vol. 50.

Berry, B. (1951) Race Relations. Boston: Houghton Miffin.

Blesanz, J. \& Sm1th, L.M. (1951) "Race Relations in Panama and the Canal Zone". Amer. J. Soctol., Vol. 57.

Blumer, H. (1958) "Recent Research into Race Relations: United States of America". Internat. Soc. Sc1. Bull., Vol 10.

Borrie, W.D. (1959) The Cultural Integration of Immigrants. Paris: Unesco.

Brunle, H. (1950) "The Cultural Assimilation of Immigrants" in Cuitural Assimilation of Immigrants, Population Studies Supplement, March 1950.

Burt, R. (1960) Colour Prejudice in Britain. Unpublished Senior Thesis, Princeton University.

Butterworth, E. (1964) "Aspects of Race Relations in Bradford" Race, Vol. 6 .

Carey, A.T. (1956) Colonial Students. London: Secker and Warburg.

Chase, S. (1952) Roads to Agreement. London: Phoenix House.

Collins, S. (1957) Coloured Minorities in Britain. London: Lutterworth Press. 
Coser, L.A. (1956) The Function of Social Conflict. London: Routledge and Kegan Paul.

Cumper, G.E. (1957) "Working Class Migrants to the U.K., October 1955". Social and Economic Studies, Vol. 6 .

Davison, R.B. (1962) West Indian Migrants. Oxford Universi ty Press.

Davison, R.B. (1964) Commonwealth Immigrants. Oxford University Press.

Desai, R. (1965) Indian Immigrants in Britain. Oxford University Press.

Economist Intell1gence Unit (1963) Studies on Immigration From the Commonwealth, 4. The Bmployment of Immigrants.

El senstadt, S.N. (1954) The Absorption of Immigrants. London: Routledge and Kegan Paul.

Falrch1ld, H.P. (1924) Imm1gration. New York: MacMillan.

Faris, E.L. (1953) "Development of the Small Group Research Movement", In Group Relations at the Crossroads, M. Sherif and M.O. Wilson (eds.) New York: Harper.

Glass, D.V. (1950) "Introduction" to Cultural Assimilation of Immigrants, Population Studies supplement, March 1950.

Glass, Ruth (1960) Newcomers London: Allen and Jnwin.

Hankins, F.M. (1934) "Social Discrimination", Encyclopaedia of the Social Sclences. London: MacMilian.

Harding, J. and Hogrefe, R. (1952) "Att1 tudes of Department Store Employees towards Negro Co-workers", J. Soc. Issues, Vol. 8 .

Henderson, Judith (1960) "A Soclological Report", in Coloured Immigrants in Britain. Oxford University Press.

H111, C.S. (1963) West Indian Migrants and the London Churches. Oxford University Press.

H1Il, M. (1953) "Some Problems of Social Distance in Intergroup Relations", in Group Relations at the Crossroads, M. Sherif and M.O. Wilson (eds.) New York: Harper.

Hunter, Kathleen (1963) H1story of Pakistanis in Britain. Norwich: Page Bros.

Hyndman, A. (1960) "The West Indian in London", in The West Indian Comes to Britain, S.K. Ruik (ed.) London: Routledge and Kegan Paul.

Irish, D.P. (1952) "Reactions of Caucasian Residents to Japanese-American Neighbours", J. Soc. Issues, Vol. 8. 
Kondapi, C. (1949) Indians Overseas. New Delh1: Indian Council of World Affairs.

Krech, D. and Crutcheleld, D.S. (1948) Theorles and Problems of Social Psychology. New York: McGraw-Hill.

Landes, Ruth (1952) "A Preliminary Statement of a Survey of Negro-White Relationships in Great Britain", Unpublished Communication, Royal Anthropological Institute, 6th May, 1952.

Lee, F.F. (1960) "Racial Patterns in a British City: An Institutional Approach", Phylon 1st Quarter 1961.

Lewis, R. (1930) "Americanization", Encyclopaedia of the Soclal Sciences. London: MacMillan.

Lieberson, S. (1961) "A, Societal Theory of Race and Ethnic Relations", Amer. Sociol. Rev., Vol. 26.

Little, K.I. (1948) Negroes in Britain. London: Kegan Paul.

Iittle, K.I. (1956) "Race and Society", in The Race Question

in Modern Sclence. London: Sidgwick and Jackson.

Lundburg, G.A. (1939) Foundations of Soclology. New York: MacMillan.

McKenzie, Barbara G. (1948) "The Importance of Contact in Determining Attitudes towards Negroes". J. Abn. Soc. Psychol., Vol. 43.

Mauco, G. (1950) "The Assimilation of Foreigners in France", in Cultural Assimilation of Immigrants, Population Studies, supplement, March 1950.

Maunder, W.F. (1955) "The New Jamaican Migration". Social and Economic Studies Vol. 4, No. 1.

Minard, R.D. (1952) "Race Relations in the Pocahontas Coal Field". J. Soc. Issues, Vol. 8.

Myrdal, G. (1944) An American Dilemma. New York: Harper.

Norgren, P.H. and Hill, S.E. (1964) Toward Fair Employment. Columbia University Press.

Park, R.E. (1926) "Our Racial Frontier on the Pacific" Survey Graphic, Vol. 9, May 1926. Reprinted in Park, R.E. Race and Culture, Glencoe Ill., Free Press.

Park. R.E. (1930) "Assimilation, Social", Encyclopaedia of the Social Sclences. London: Macmillan.

Park, R.E. and Burgess, E. (1924) Introduction to the Science of Sociology. Chicago: University Press.

Patterson, Sheila (1963) Dark Strangers. London: Tavistock Publications.

Peppard, Nadine (1963) "The Co-ordination of Social Sciences for M1grant Workers". Institute of Race Relations Newsletter, supplement, May 1963. 
Pettigrew, T.P. (1959) "Regional Differences in Anti-Negro Prejuaice", J.Abn. Soc. Psychol., Vol. 59.

Pettigrew, T.F. (1961) "Social Psychology and Desegregation Research". Amer. Psychologist, Vol. 16.

Raab, E. and Lipset, S.M. (1959) Prejudice and Society. New York: Anti-Defamation League.

Reid, Janet (1956) "Employment of Negroes in Manchester". The Sociological Review Vol.4.

Reltzes, D.C. (1953) "The Role of Orgenizational Structures" J. Soc. Issues, Vol. 9.

Reitzes, D.C. (1959) "Institutional Structure and Race Relations". Phylon 1st quarter, 1959.

Rex, J. (1965) "Integration: the Reality". New Society, 12th August, 1965.

Richmond, A.H. (1954) Colour Prejudice in Britain. London: Routledge and Kegan Paul.

Richmond, A.H. (1957) "The Study of Race Relations". Man Vol. 57.

Richmond, A.H. (1958) "Recent Research in Race Relations: Great Britain". Internat. Soc. Sc1. Bull., Vol. 10.

Richmond, A.H. (1960) "Applied Social Science and Public Policy Concerning Race Relations". Race Vol. 1.

Roberts, G.W. and Mills, D.0. (1958) "Study of External Migration Affecting Jamaica: 1953-1955" Social and Economic Studies, Vol. 7 .

Rose, A.M. (1956a) "The Roots of Prejudice", in The Race Question in Modern Sclence. Paris: Unesco.

Rose, A.M. (1956b) "Intergroup Relations vs. Prejudice: Pertinent Theory for the Study of Social Change". Soc. Probl., Vol. 4 .

Rose, A.M. (1957) "The Causes of Prejudice", in American Minorities, M.I. Barron (ed.) New York: Alfred A. Knope.

Senior, C, and stanley, D. (1955) A Report on Jamaican Migration to Great Britain. Kingston, Jamaica: Government Publications.

Senior, C. (1956) "Race Relations and Labour Supply in Great Britain". Paper for the American Soclological Society, Race Relations Section, Detro1t, 1956. Published with ininor alterations in Soc. Probl, Vol. 4. 1957.

Sevion, S. (1961) "The West Indians in our Midst". The Times 27 th Augrust, 1961.

Simmel, G. (1950) "The Stranger", in The Sociology of Georg Simmel, K.H. Wolff (ed. and translator) Glencoe, Ill.: Free Press. 
Stephens, I. (1956) "Employment of Coloured Workers in the Birmingham Area". London: Institute of Personnel Management Occasional Paper.

Stouffer, S.A., Suchnan, E.A., Devinney, L.C., Star, Shirley, A., Williams, R.M., Jnr. (1949) Studies in Social Psychology in World War II, Vol. I. The American Soldier: Adjustment During Army Life. Princeton: University Press.

Triandis, H.C. and Triandis, L.M. (1961) "Race, Social Class, Religion and Nationality as Determinants of Social Distance". J. Abn. Soc. Psychol., Vol. 61.

Turner, R.M. (1961) "The Relative Position of the Negro Male in the Labour Force of large American Cities." Aner. Sociol. Rev. Vol. 16.

Useem, O.C. and Useem, Ruth H. (1945) "Minority Group Pattern in Prairie Society". Amer. J. Sociol., Vol. 50.

Waughray, v. (1961) "Race Relations in Britain". Peace News Pamphlet.

W1 ckenden, J. (1958) Colour in Britain. Oxford University Press.

Williams, R.M., Jnr. (1957) "Basic Assumptions and Principle Techniques in Intergroup Action Programs", in American Minorities, M.L. Barron (ed.) New York: Aifred A. Knopr.

Wood, D. (1960) "A General Survey", in Coloured Immigrants in Britain. Oxford University Press.

Zawadski, B. (1948) "The Limitations of the Scapegoat Theory of Prejudice". J. Abn. Soc. Psychol., Vol. 43. 